The University of Maine

DigitalCommons@UMaine

Electronic Theses and Dissertations

Fogler Library

$8-2002$

\title{
Late holocene sea-level change around Newfoundland
}

Julia Daly

Follow this and additional works at: http://digitalcommons.library.umaine.edu/etd

Part of the Geology Commons, and the Glaciology Commons

\section{Recommended Citation}

Daly, Julia, "Late holocene sea-level change around Newfoundland" (2002). Electronic Theses and Dissertations. 600. http://digitalcommons.library.umaine.edu/etd/600

This Open-Access Dissertation is brought to you for free and open access by DigitalCommons@UMaine. It has been accepted for inclusion in Electronic Theses and Dissertations by an authorized administrator of DigitalCommons@UMaine. 


\title{
LATE HOLOCENE SEA-LEVEL CHANGE
}

AROUND NEWFOUNDLAND

By

Julia F. Daly

B.A. Carleton College, 1994

M.S. University of Delaware, 1997

\author{
A THESIS \\ Submitted in Partial Fulfillment of the \\ Requirements for the Degree of \\ Doctor of Philosophy \\ (in Geological Sciences)
}

August, 2002

Advisory Committee:

Daniel F. Belknap, Professor of Geological Sciences, Advisor

Joseph T. Kelley, Professor of Geological Sciences

Kirk A. Maasch, Associate Professor of Geological Sciences

Detmar Schnitker, Professor of Marine Sciences

Trevor Bell, Assistant Professor of Geography, Memorial University of Newfoundland 


\title{
LATE HOLOCENE SEA-LEVEL CHANGE \\ AROUND NEWFOUNDLAND
}

\author{
By Julia F. Daly \\ Thesis Advisor: Dr. Daniel F. Belknap \\ An Abstract of the Thesis Presented \\ in Partial Fulfillment of the Requirements for the \\ Degree of Doctor of Philosophy \\ (in Geological Sciences) \\ August, 2002
}

Analysis of basal salt-marsh peats and tide-gauge data from several locations around Newfoundland yield high-resolution late Holocene sea-level reconstructions and constrain differential sea-level change. The transition between rising and falling local sea levels and the influence of glacioisostasy on relative sea-level change around Newfoundland through the late Holocene are not well known from previous research. The patterns of local relative sea-level change during this time have important implications for constraining numerical models of sea-level change, and therefore inferences about ice sheet thickness and the response of the lithosphere to deglaciation. I investigated the stratigraphy of salt marshes at four locations around Newfoundland: a) Hynes Brook (SW), b) St. Paul's Inlet (west), c) Deadman's Bay (NE), and d) Placentia (SE). At each location, surficial samples were used to determine the modern floral and foraminiferal zonation. These zones were applied to basal peat samples to constrain the paleo-mean high water (MHW) level associated with the sample. Sea-level histories for

each location are constructed by combining AMS ${ }^{14} \mathrm{C}$ dates with paleo-MHW ranges for 
a series of basal samples. At three locations (Hynes Brook, Deadman's Bay, Placentia), sea level has risen during this time. At St. Paul's Inlet, sea-level change during the late Holocene appears to have a more complex history. Sea level has remained close to present over the past 2,000 years, but may have experienced a subtle transition from falling to rising between 2000 and 1000 years BP. This trend contrasts strongly with the transgression interpreted at Hynes Brook, approximately $160 \mathrm{~km}$ to the southwest, and supports the hypothesis of continuing glacioisostatic influence on the Northern Peninsula. Identification of the timing and position of this hinge and differential late Holocene sealevel trends provide important constraints on numerical models predicting isostatic responses to deglaciation. 


\section{ACKNOWLEDGEMENTS}

I would like to thank Dan Belknap and Joe Kelley for their help in shaping this project, thoughtful criticism, and continuing encouragement and support. Kirk Maasch and Detmar Schnitker provided valuable advice, and are thanked for participating on the committee. Trevor Bell provided substantial in-kind support for this research and facilitated fieldwork in Newfoundland. Alison Brandes, Alice Kelley, and Shane Greene provided able field assistance and good company. Roland Gehrels introduced me to foram analysis and I am grateful for his interest in the project and good counsel. Tim Patterson and Jean-Pierre Guilbault assisted with foram identification. Kelley Edwards assisted with SEM image acquisition. The Geological Society of America and the University of Maine Association of Graduate Students funded this research. Tim Jull at the University of Arizona AMS facility arranged for two-dozen radiocarbon dates at a reduced fee. Encouragement from Steve Norton, Meredith Kelly, and Martin and Lesa O'Connell is appreciated. Doug Reusch is gratefully acknowledged for support in the field, lab, and home. 


\section{TABLE OF CONTENTS}

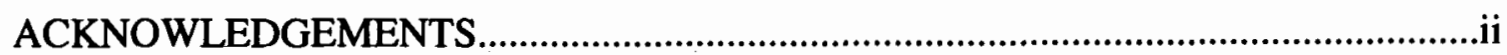

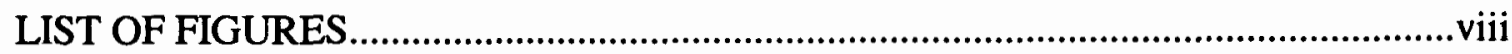

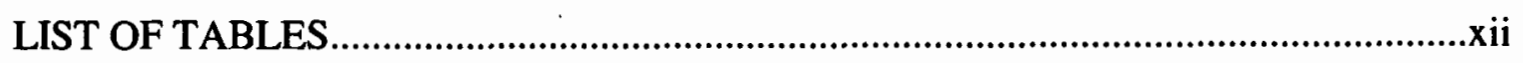

\section{CHAPTER}

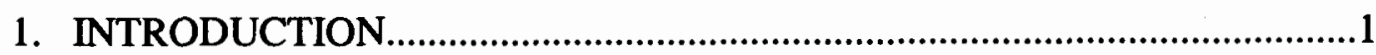

Introduction and Statement of Problem...............................................1

Previous Research....................................................................

Studying late Holocene sea-level change.................................

Salt-marshes and sea-level rise...................................

Salt-marsh records.................................................12

Tide-gauge records........................................................ 14

Sea-level change around Newfoundland....................................15

Numerical predictions............................................... 16

Pleistocene-Holocene records........................................16

\section{CHAPTER}

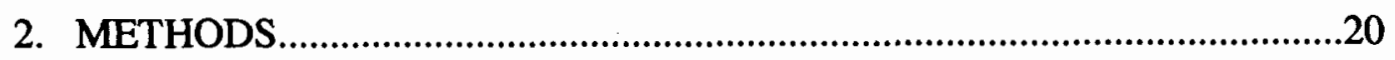

Field Methods............................................................................20

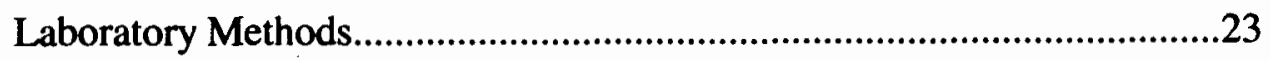

Foraminiferal Analysis...................................................23

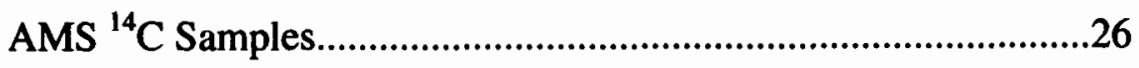

Tide-Gauge Analysis.....................................................26

Definition and Description of Lithologic Units...................................27 


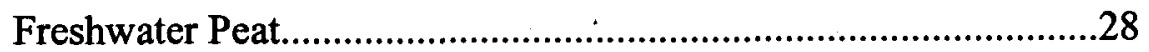

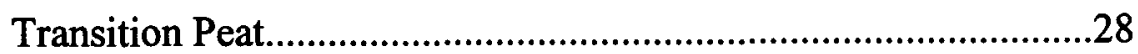

Higher High Marsh Peat..................................................................29

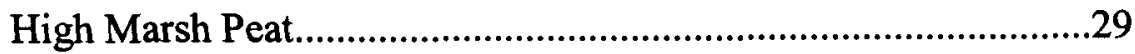

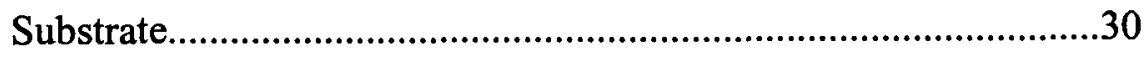

\section{CHAPTER}

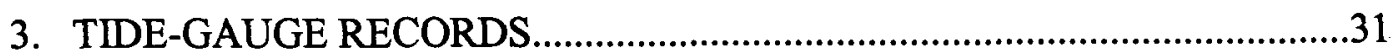

Introduction and Previous Work....................................................................31

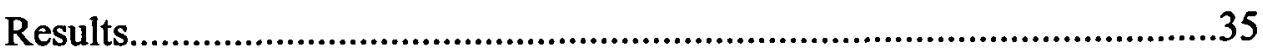

Linear Regression Analysis.........................................................36

Wavelet and Evolutionary Spectral Analysis...................................38

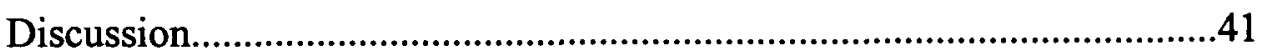

CHAPTER

4. MODERN FORAMINIFERAL SURFICIAL ZONATIONS..........................44

Introduction and Previous Research............................................................44

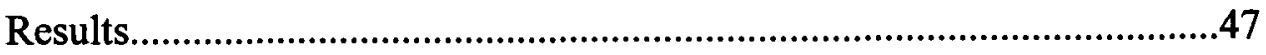

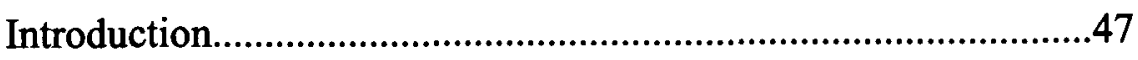

Population and Diversity.................................................................47

Cluster Analysis........................................................................49

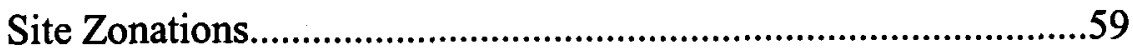

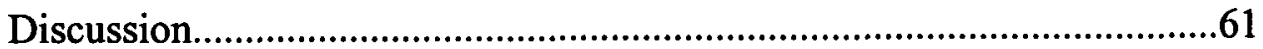

\section{CHAPTER}

5. HYNES BROOK, PORT-AU-PORT PENINSULA .........................................63 
Introduction and Geologic Setting...........................................................63

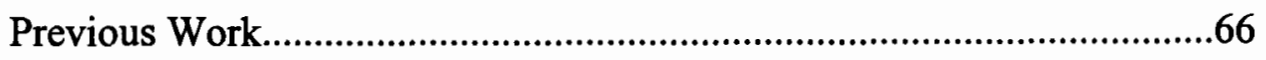

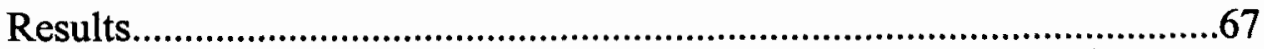

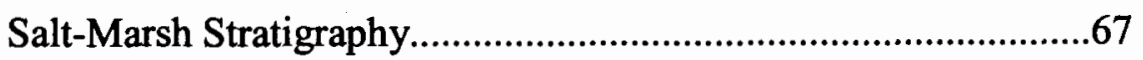

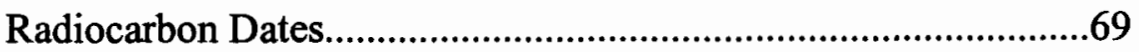

Sea-level Reconstruction...............................................................72

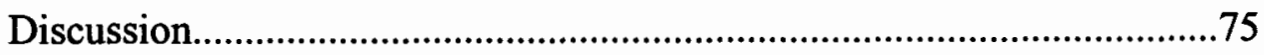

\section{CHAPTER}

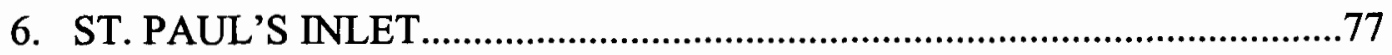

Introduction and Geologic Setting............................................................77

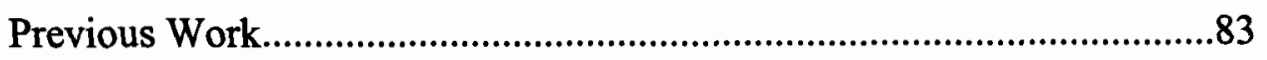

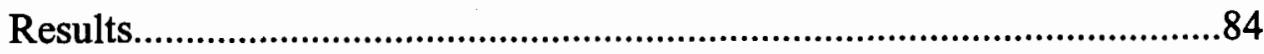

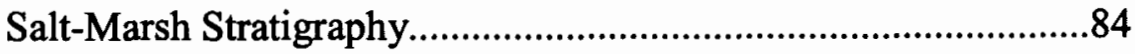

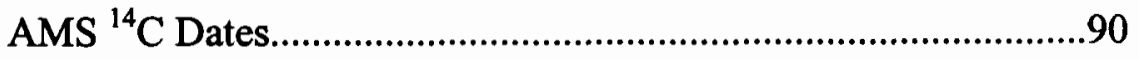

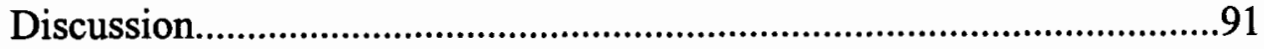

\section{CHAPTER}

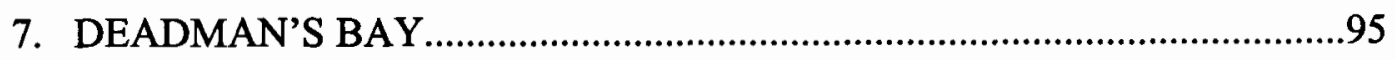

Introduction and Geologic Setting...........................................................95

Previous Work ......................................................................................101

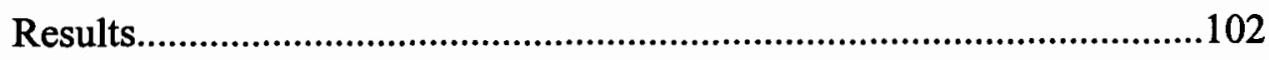

Salt-Marsh Stratigraphy..............................................................102

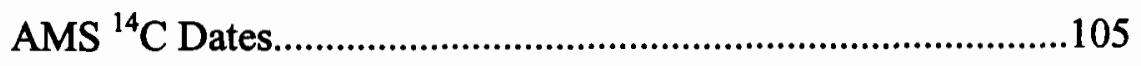

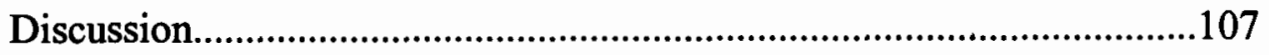




\section{CHAPTER}

8. PLACENTIA, AVALON PENINSULA...................................................111

Introduction and Geologic Setting.........................................................111

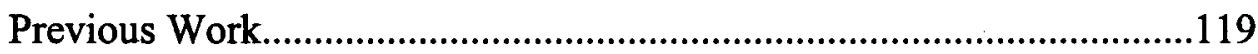

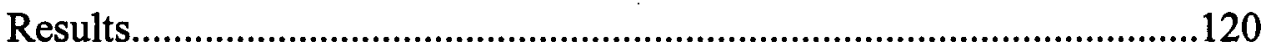

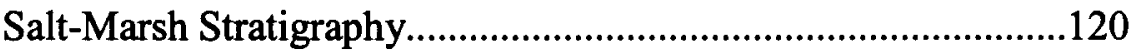

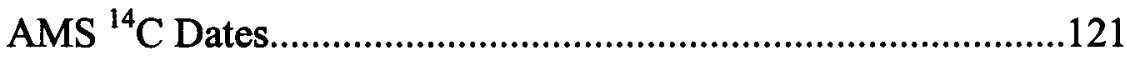

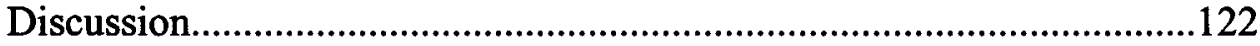

\section{CHAPTER}

9. LATE HOLOCENE SEA-LEVEL CHANGE AROUND

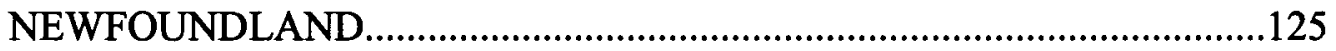

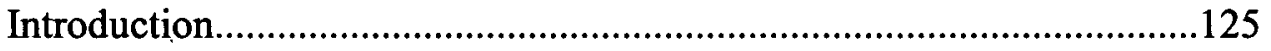

Comparison to Published Sea-Level Reconstructions..............................128

Glacioisostatic Hinge...................................................................130

Migration of Collapsing Forebulge? ............................................132

Comparison to Numerical Models................................................133

Comparison to Maritimes \& Gulf of Maine...................................136

CHAPTER

10. CONCLUSIONS AND FUTURE WORK ……..........................................137

Project Objectives and Conclusions........................................................137

Future Research................................................................................139

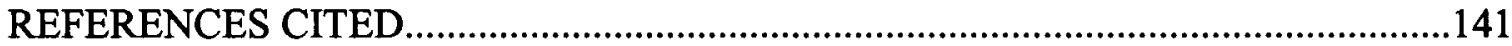

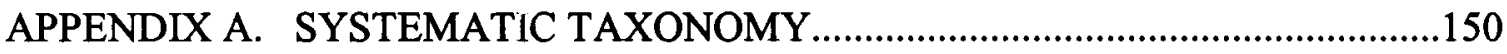




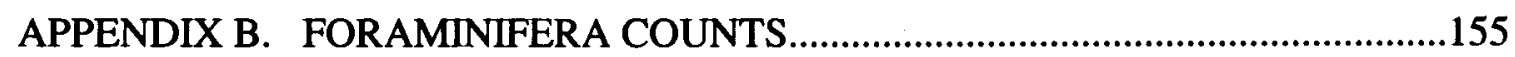

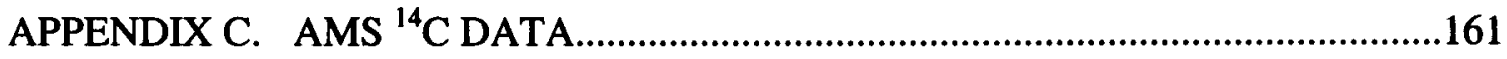

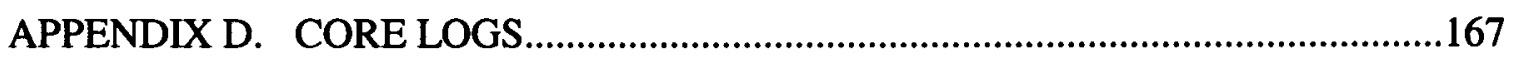

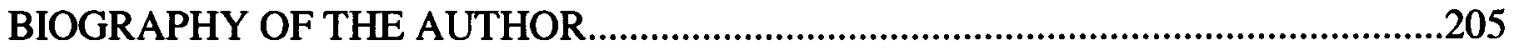




\section{LIST OF FIGURES}

Figure 1.1 Detail of reconstructed "maximum model" LGM ice sheet over

Newfoundland.

Figure 1.2 Predicted sea-level histories for Newfoundland................................................

Figure 1.3 Sea-level change predicted by the ICE 4-G model.........................................6

Figure 1.4 Conceptual model of marsh development.......................................................9

Figure 1.5. Schematic cross-section of a fringing fluvial marsh.......................................10

Figure 1.6 Predicted sea-level curves at four locations affected at different times by the migration of a proglacial forebulge.

Figure 1.7 Comparison of a local relative sea-level curve in a formerly glaciated region (Maine) with a eustatic sea-level curve (Barbados).........................................18

Figure 2.1 Location map showing salt mash sites...........................................................21

Figure 2.2 Predicted water level variations at five subordinate stations over a two-week period 24

Figure 3.1 Location map of tide gauges evaluated in Newfoundland and Quebec. .33

Figure 3.2 Previous water level studies using Maritime tide gauge data

Figure 3.3 Tide gauge records from six sites in Newfoundland and Quebec.

Figure 3.4 Wavelet analysis results of detrended tide gauge records .39

Figure 3.5 Synthetic tide gauge record and components. .40

Figure 3.6 Contours of vertical land movement based on linear regression of tide-gauge records.

Figure 4.1 Location map of surficial foraminifera sampling sites 
Figure 4.2 Foraminiferal populations of surface samples from five sites around

Newfoundland

Figure 4.3 SEM images of $J$. macrescens and B. pseudomacrescens 50

Figure 4.4a Surface sample transect 1, Hynes Brook......................................................51

Figure 4.4b Surface sample transect 2, Hynes Brook.......................................................52

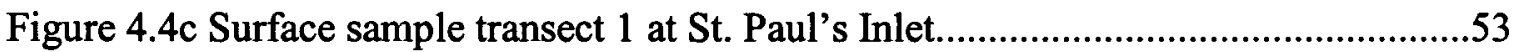

Figure 4.4d Surface sample transect 2 at St. Paul's Inlet.................................................54

Figure 4.4e Surficial population at Village Cove, NWI...................................................55

Figure 4.4f Surficial population at Placentia...................................................................56

Figure 4.5 Results of complete cluster analysis..........................................................57

Figure 4.6 Cluster composition.................................................................................58

Figure 4.7 Cluster zonations at each site........................................................................60

Figure 5.1 Location map for site at Hynes Brook...............................................................64

Figure 5.2 Oblique view of Hynes Brook field area.........................................................65

Figure 5.3 Cross-section from $\mathrm{A}-\mathrm{A}^{\prime}$ on the north side of Hynes Brook........................68

Figure 5.4 Cross-section from B - B' on the south side of Hynes Brook...........................71

Figure 5.5 Late Holocene sea-level change in southwestern Newfoundland......................73

Figure 5.6 Post-glacial sea-level change in southwestern Newfoundland...........................74

Figure 6.1 Aerial photo of the south side of St. Paul's Inlet.............................................78

Figure 6.2 Generalized geomorphic map of St. Paul's Inlet............................................79

Figure 6.3 Barrier transect at St. Paul's Inlet, view north toward Inlet............................80

Figure 6.4 Plants from the low and high marsh at St. Paul's Inlet. .................................82

Figure 6.5 Barrier transect at St. Paul's Inlet, view south-southeast..................................85 


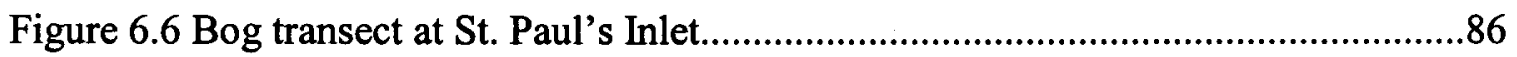

Figure 6.7 Cross-section across the barrier along transect $\mathrm{A}-\mathrm{A}^{\prime}$ at St. Paul's Inlet........87

Figure 6.8 Cross-section across the bog on transect B - B' at St. Paul's Inlet...................89

Figure 6.9 Sea level reconstructions for St. Paul's Inlet based on new AMS

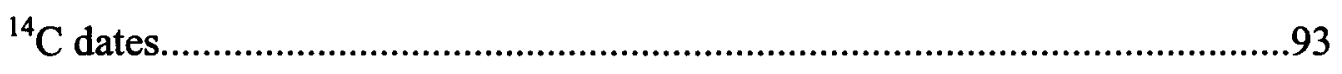

Figure 7.1 Aerial photograph and location map for Deadman's Bay barrier....................96

Figure 7.2 Geomorphic map of Deadman's Bay barrier.....................................................97

Figure 7.3 Close-up view of marsh surface looking east, near transect 1 ........................98

Figure 7.4 Southern surface sample transect at Deadman's Bay, view to the east.............99

Figure 7.5 Stratigraphic cross-section of the northern (proximal) transect at

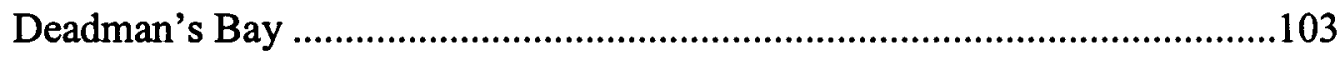

Figure 7.6 Stratigraphic cross-section along transect B, Deadman's Bay........................104

Figure 7.7 Late Holocene relative sea-level change reconstruction for

Deadman's Bay.

Figure 7.8 Late Pleistocene - Holocene sea-level change reconstruction for northeast

Newfoundland.

Figure 8.1 Location of field area in Southeast Arm, Placentia.

Figure 8.2 Aerial photographs of Placentia c. 1950, prior to re-settlement of many people

from outports

Figure 8.3 Map of Placentia from c. 1703

Figure 8.4 Generalized geomorphic maps of A) Placentia, and B) the field site.

Figure 8.5 Oblique photograph of field area indicating major floral zones and the transect

line. 
Figure 8.6 Cross-section of marsh in Southeast Arm, Placentia...................................118

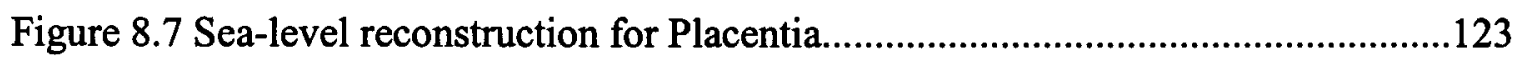

Figure 9.1 Location map showing salt marsh sites ......................................................126

Figure 9.2 Comparison of late Holocene sea-level reconstructions for Newfoundland with sea-level reconstructions from the Gulf of Maine..................................127

Figure 9.3 Comparison to sea-level curves from western Newfoundland........................129

Figure 9.4 Postglacial sea-level lowstand (meters) and $0 \mathrm{~m}$ isobase indicating the hinge

line.

Figure 9.5 Gravity anomaly map of Newfoundland, from the Atlantic region gravity anomaly map of Dehler and Roest (1998). 


\section{LIST OF TABLES}

Table 1.1 Foraminiferal zones (modified from Gehrels, 1994).......................................11

Table 2.1 Predicted and measured water level ranges near five main field sites...............22

Table 2.2 Difference between measured high water and projected MHW based on predicted water levels

Table 2.3 Estimated elevation uncertainty due to approximation of MHW at field location .23

Table 3.1 Location and operation of tide gauges evaluated in this study. .36

Table 3.2 Local relative sea-level change calculated by linear regression analysis of tide-gauge records.

Table 4.1 Summary of surficial samples collected. .47

Table 4.2 Agglutinated and clacareous foraminifera identified in this study. .49

Table 5.1 Tidal range data for Port-au-Port and Hynes Brook. .66

Table 5.2 Floral and faunal zones at Hynes Brook, Newfoundland. .67

Table 5.3 Radiocarbon data for southwestern Newfoundland from this and other studies .70

Table 6.1 Tidal range projections for Portland Cove. .81

Table 6.2 Salt-marsh floral and faunal zones at St. Paul's Inlet. . .83

Table 6.3 Radiocarbon data for St. Paul's Inlet. .91

Table 7.1 Tidal range projections for Valleyfield and Deadman's Bay. 100

Table 7.2 Foraminiferal zones at Village Cove, New World Island. 100

Table 7.3 AMS ${ }^{14} \mathrm{C}$ dates for NE NFLD. 106 
Table 8.1 Projected tidal ranges at Argentia and measured range at Placentia................116

Table 8.2 Floral and foraminiferal zones at Southeast Arm, Placentia...........................119

Table 8.3 Radiocarbon data for Southeast Arm, Placentia..............................................122 


\section{Chapter 1}

\section{INTRODUCTION}

\section{Introduction and Statement of Problem}

Late Holocene sea-level change at any location is a composite of eustatic sealevel change and local and regional processes (Belknap et al., 1987; Kelley et al., 1992; Gehrels et al., 1996). Glacioisostatic adjustment, neo-tectonic activity, and hydroisostatic adjustment may be important controls on local relative sea-level change. Determination of a eustatic sea-level curve and the historic rate of global sea-level rise are confounded by the difficulty in separating the relative contribution of eustatic and regional controls on a given record. The eastern coast of North America is a stable passive margin with no significant tectonic activity influencing sea-level change through the Holocene (Gehrels et al., 1996). Mid-to-late Holocene sea-level curves and historic tide-gauge records both indicate a consistent variation in local sea-level change from north to south (Emery and Aubrey, 1991; Gornitz, 1995; Douglas and Peltier, 2002). Variable glacioisostatic adjustment is inferred to be the cause of this geographic trend. However, the shoreline of New England and the Maritimes is parallel to the margin of the former Laurentide ice sheet, inhibiting determination of the glacioisostatic contribution to the sea-level record for the late Holocene. The definition of glacioisostatic adjustment is relevant not only to determination of eustatic sea-level change, but also to numerical models relying on sealevel histories in glaciated areas to constrain models of ice thickness and lithospheric response to unloading. 
Isostasy, in its broadest definition, refers to the relationship between large, regional topographic variations and the distribution of mass in the Earth's interior. Continental glaciers, such as the Laurentide ice sheet, contain enough mass to isostatically depress the crust beneath them. As the crust is depressed, material in the mantle flows away from the center of depression. Immediately beyond the boundary of the ice sheet, the crust is warped up slightly; this ridge is termed a marginal forebulge or proglacial forebulge, as first described by Daly (1934).

During deglaciation, the crust rebounds and the proglacial forebulge collapses as the ice mass shrinks. The collapse rate of the forebulge and "return flow" of mantle material is controlled by Earth rheology (Douglas and Peltier, 2002). Sea-level reconstructions are used to constrain models of Earth rheology. These models typically divide the Earth into three rheological layers: an elastic lithosphere, an upper mantle behaving responding as a fluid to events on long ( $>200 \mathrm{yr})$ timescales, and a more viscous lower mantle (Davis and Mitrovica, 1996). These models may be run to simulate postglacial sea-level changes, or may focus on predicting current rates of local relative sea-level change (Peltier, 1999; Douglas and Peltier, 2002). A critical change in sea-level trend, the zero meter isobase, defines the boundary between locally relative rising and falling sea levels. This transition is termed the hinge or hingeline, and refers to a geographic area. This hinge varies temporally. Its position may be interpreted from a postglacial sea-level reconstruction by the sea level lowstand at a given location.

Sea-level histories along a transect perpendicular to the former ice margin allows determination of the rate and timing of glacioisostatic adjustment. Located at the eastern edge of North America and close to the margin of last-glacial maximum (LGM) ice 
sheets, Newfoundland's variable shoreline is an ideal place to investigate differential glacioisostatic adjustment through the late Holocene (Figure 1.1). Numerical models predicting local relative sea-level changes suggest two dominant types of sea-level curves for Newfoundland (Figure 1.2). A type A sea-level curve is characterized by a postglacial highstand and fall to present (Quinlan and Beaumont, 1981). A post-glacial highstand, rapid fall to a lowstand, and subsequent gradual rise to present mean sea level (MSL) characterizes a type B sea-level curve. A recent numerical model, ICE-4G, predicts sea-level trends on smaller spatial and shorter temporal scales (Peltier, 2002). For the present, this model predicts rising sea-level around the northern, eastern, and southern Newfoundland coasts and falling sea-level along most of the western coast (Figure 1.3).

The transition between presently rising and falling local sea levels and the influence of glacioisostasy on relative sea-level change around the island through the late Holocene are not well constrained. Few studies have considered sea-level change around the island during the late Holocene, and none have systematically reconstructed a highresolution record of late Holocene sea-level change at one location. The patterns of local relative sea-level change during this time have important implications for constraining numerical models of sea-level change, and therefore inferences about ice sheet thickness and the mechanical response of the lithosphere to deglaciation. There are also important implications for archeology and evaluation of current rates of sea-level rise in response to global warming. 


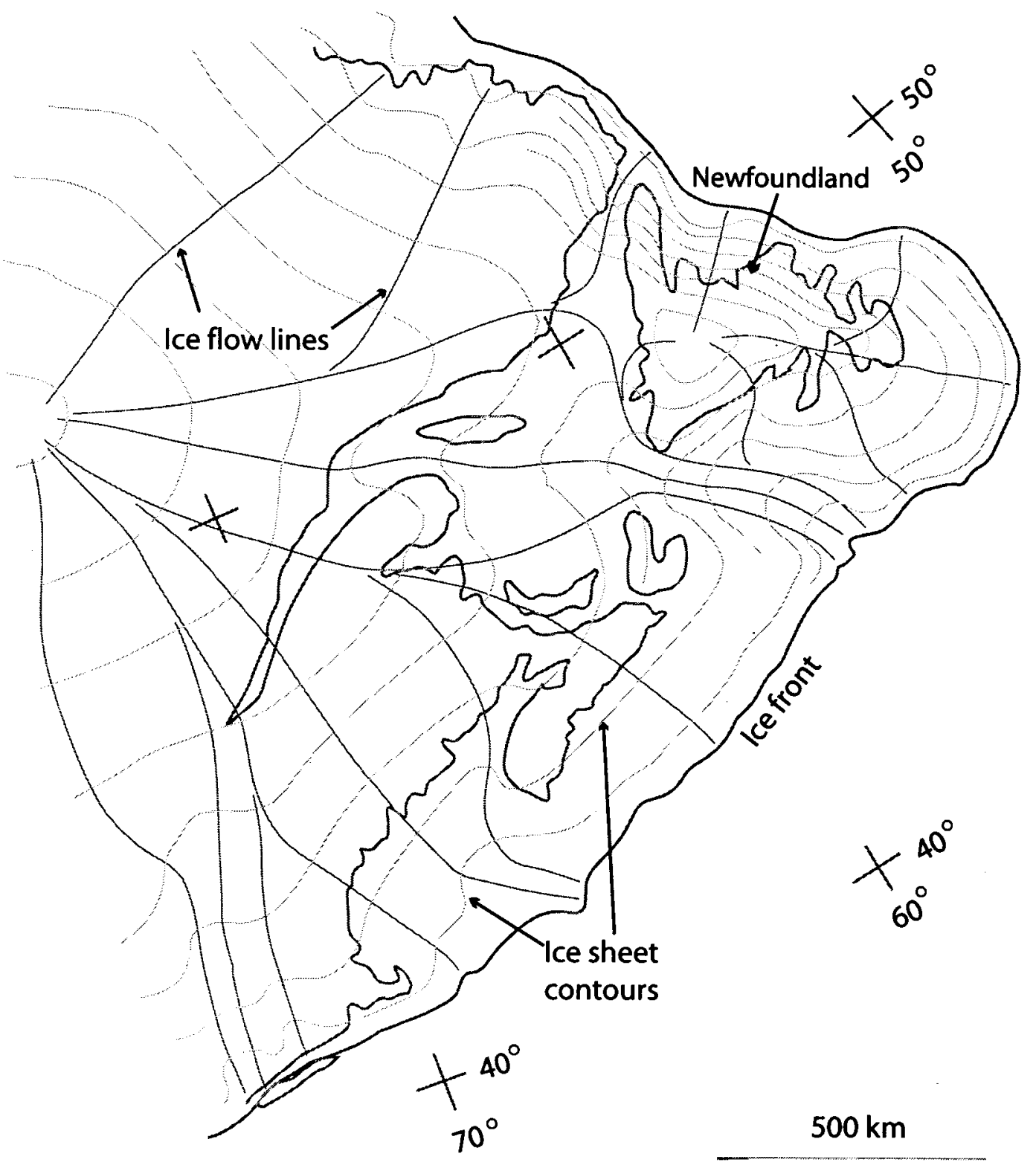

Figure 1.1 Detail of reconstructed "maximum model" LGM ice sheet over eastern North America (from Hughes, 1998). 


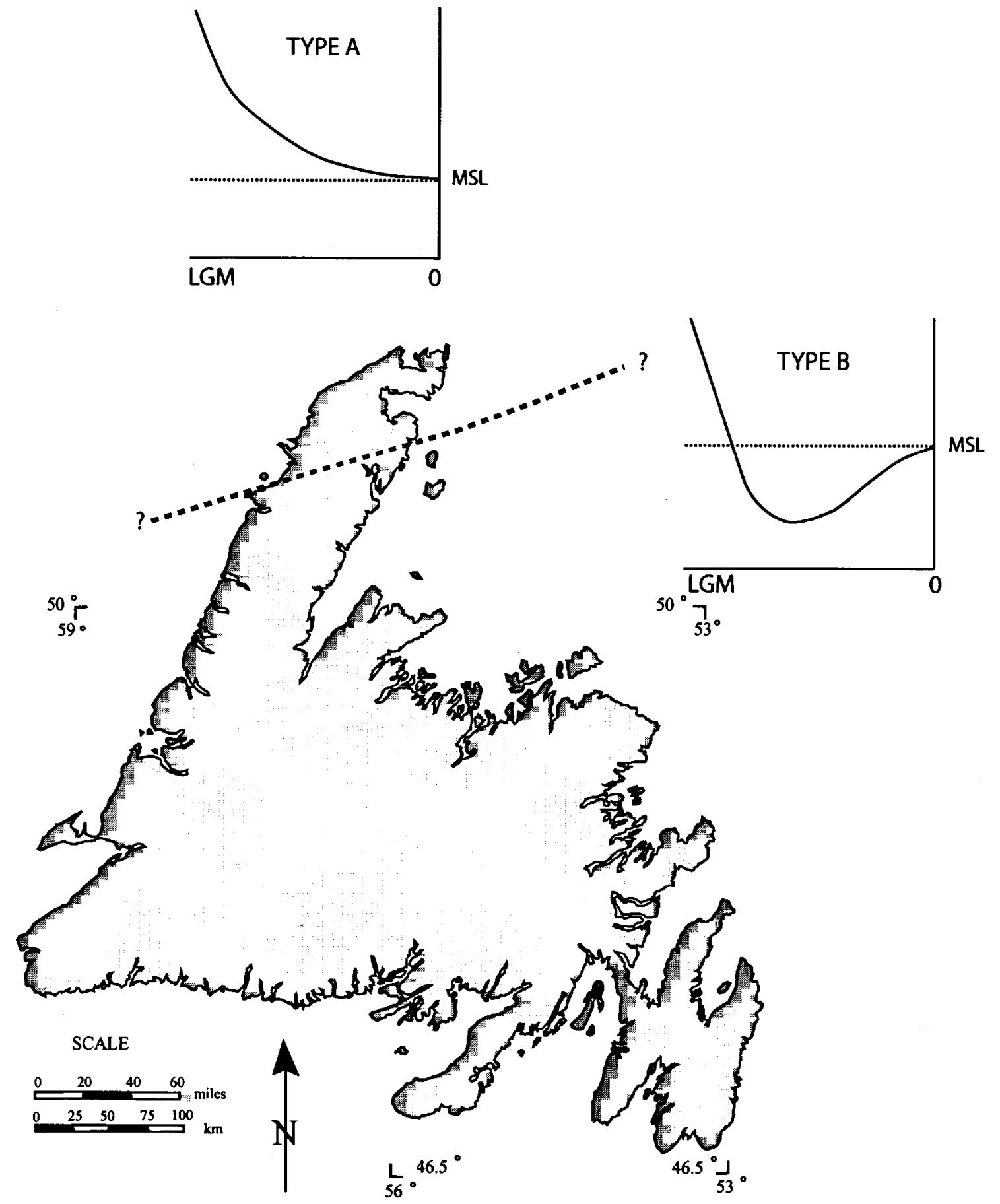

Figure 1.2 Predicted sea-level histories for Newfoundland (modified from Liverman, 1994). The type A sea-level history of continuous sea-level fall since deglaciation is predicted for the tip of the Northern Peninsula. A type B sea-level history is predicted for the rest of the island. The elevation of the post-glacial highstand and depth of the subsequent lowstand is expected to vary geographically and temporally. The transition, or hinge line, between rising and falling sea level is not well constrained. 


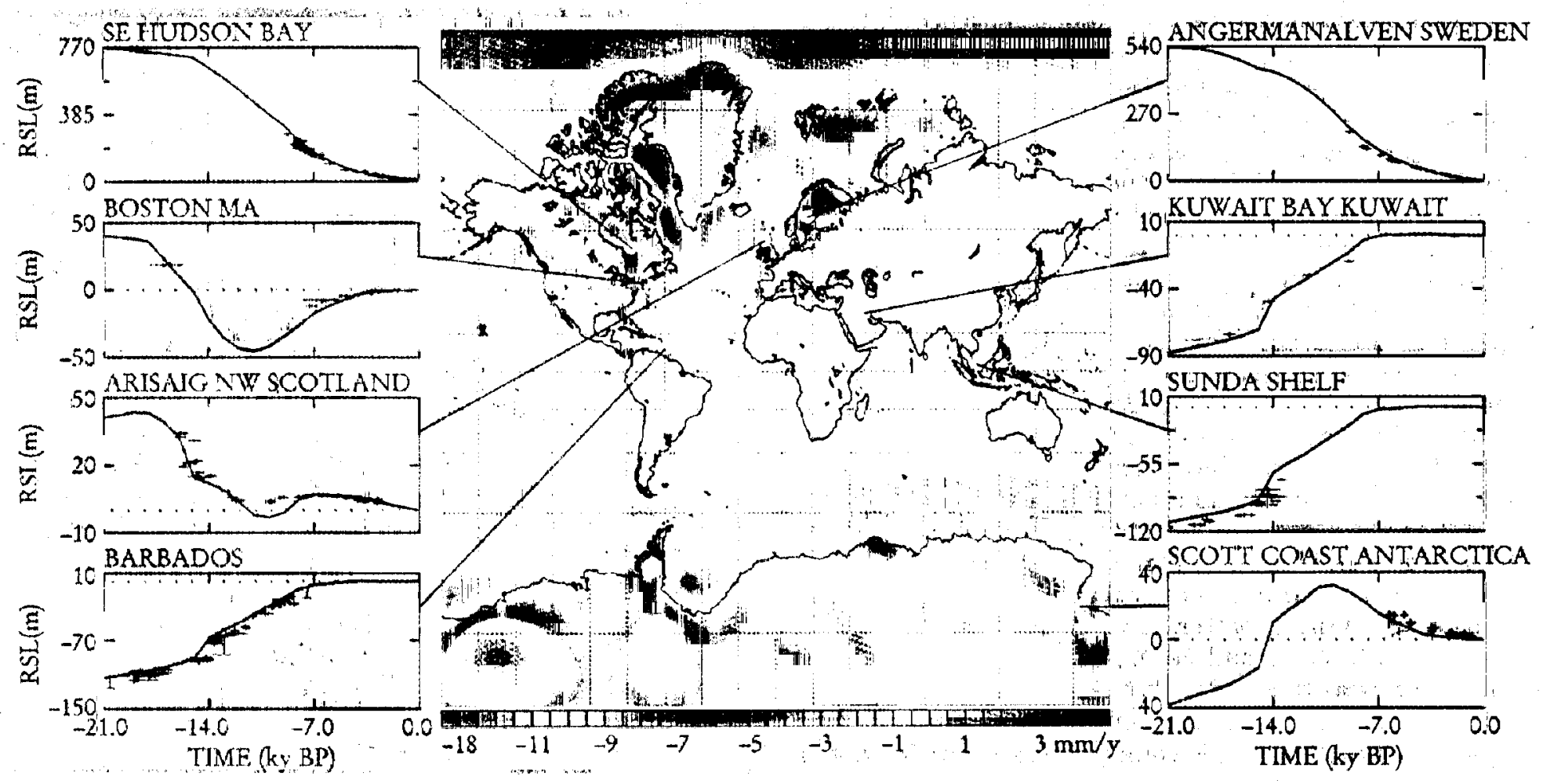

Figure 1.3 Sea-level change predicted by the modified ICE 4G model, showing Newfoundland at approximately $0 \mathrm{~mm} / \mathrm{yr}$ change (Peltier, 2002). 
The goal of this study is to evaluate differential late Holocene sea-level change and the continuing influence of glacioisostasy on sea-level change. This is accomplished by reconstructing late Holocene local relative sea-level change at four sites around Newfoundland and comparing late Holocene sea-level trends to historic sea-level change records. The late Holocene sea-level changes are reconstructed from analysis of salt-marsh stratigraphy and foraminiferal assemblages complemented by $\mathrm{AMS}{ }^{14} \mathrm{C}$ dating of basal marsh peats. Historic sea-level trends are determined from analysis of tidegauge records at sites around Newfoundland and the Gulf of St. Lawrence. This study will consider the following questions:

- Is there a significant geographic trend in sea-level change around the island during the late Holocene?

- How do late Holocene sea-level changes compare to historic sea-level trends?

- Can the signal of glacioisostatic adjustment be extracted from late Holocene sealevel trends?

- What is the nature of the transition between areas of rising and falling sea level during the late Holocene?

\section{Previous Research}

\section{Studving Late Holocene Sea-level Change}

Salt Marshes and Sea-level Rise. Salt marshes are good indicators of sea-level change because marsh flora and fauna are zoned with respect to frequency of tidal inundation. Early salt-marsh research recognized that the configuration of a marsh changes through time and will change in response to rising sea level. As a low marsh develops, it will trap 
sediment, raising the surface of the marsh. Eventually this leads to the development of a high marsh flora that often expands over the low marsh. High marsh expands in two directions in this model. Due to sea-level rise, it will expand landward to conformably overlie transitional/brackish peat. If sediment deposition is sufficient to outpace sea-level rise in the low marsh, the marsh surface will become elevated and high marsh will conformably overlie low marsh. Mudge (1858) observed that marsh sediments overlie upland material, and Shaler (1885) observed that, through continued sedimentation, the marshes would accrete and prograde through time. These two concepts were combined in seminal work by Redfield (1972) outlining a model for the development of a wedge of salt-marsh sediments growing landward and seaward in a transgressive environment behind a prograding spit at Barnstable, MA (Figure 1.4) (Redfield, 1965; Redfield and Rubin, 1972). Variations on this model reflect the depositional setting of the marsh (fluvial versus backbarrier) and the influence of channel migration on the development of the marsh (Belknap et al., 1983; Kelley et al., 1988) (Figure 1.5).

Analysis of fossil foraminiferal assemblages and associated AMS ${ }^{14} \mathrm{C}$ dates from saltmarsh peats yield high-resolution records of sea-level change. Floral assemblages for each zone vary geographically, but along the east coast of the United States Spartina alterniflora characterizes low marsh, Spartina patens typifies high marsh, and Juncus gerardii characterizes higher high marsh. The transition to the upland, or more brackish environment, is characterized by Scirpus and Typha species. In the Gulf of Maine, the vertical ranges associated with these floral zones vary (Gehrels et al., 1996).

More recently, agglutinated foraminifera populating the marsh were used to delineate different marsh zones (Scott and Medioli, 1978, 1980) (Table 1.1). Two major 


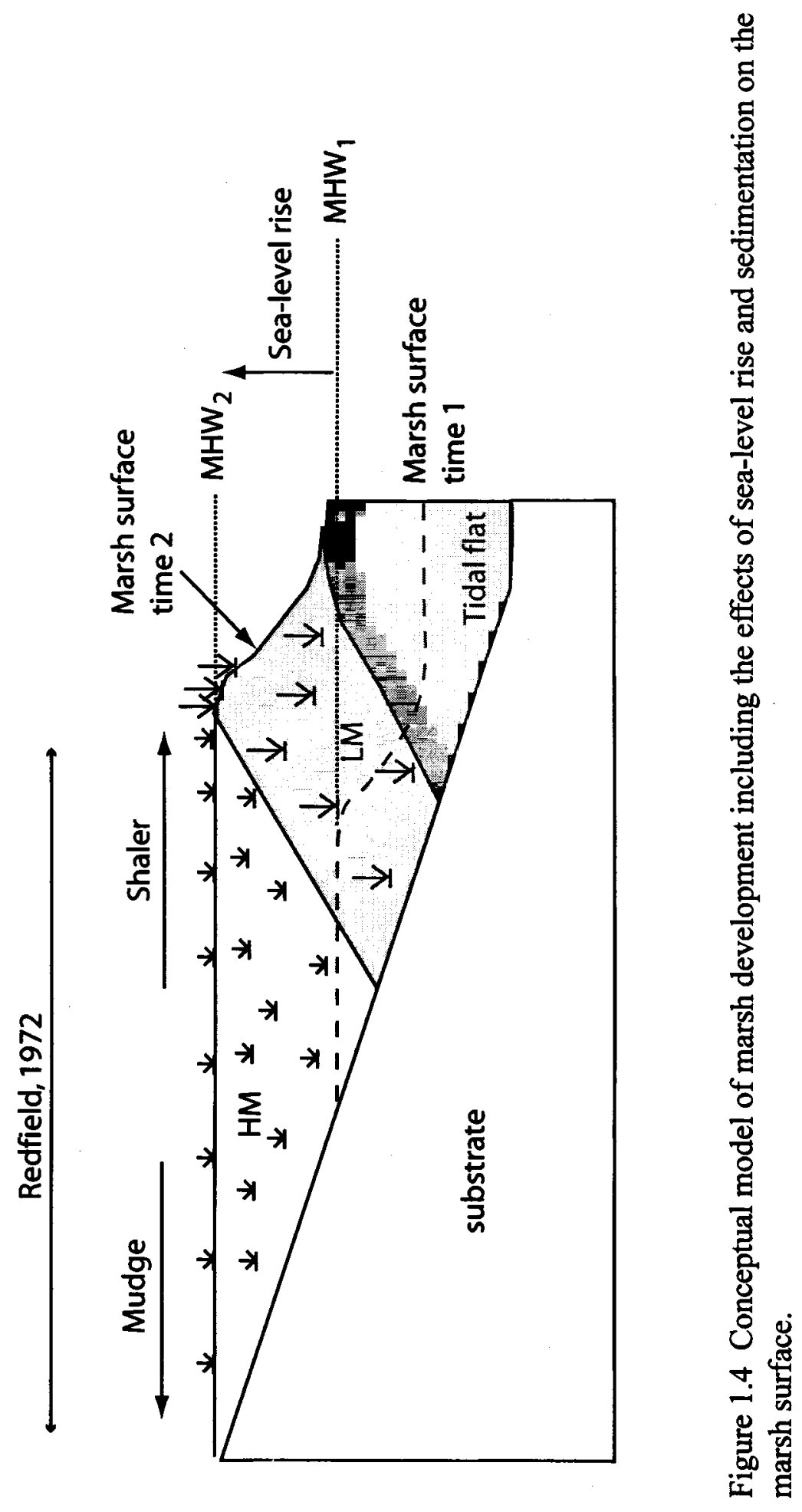




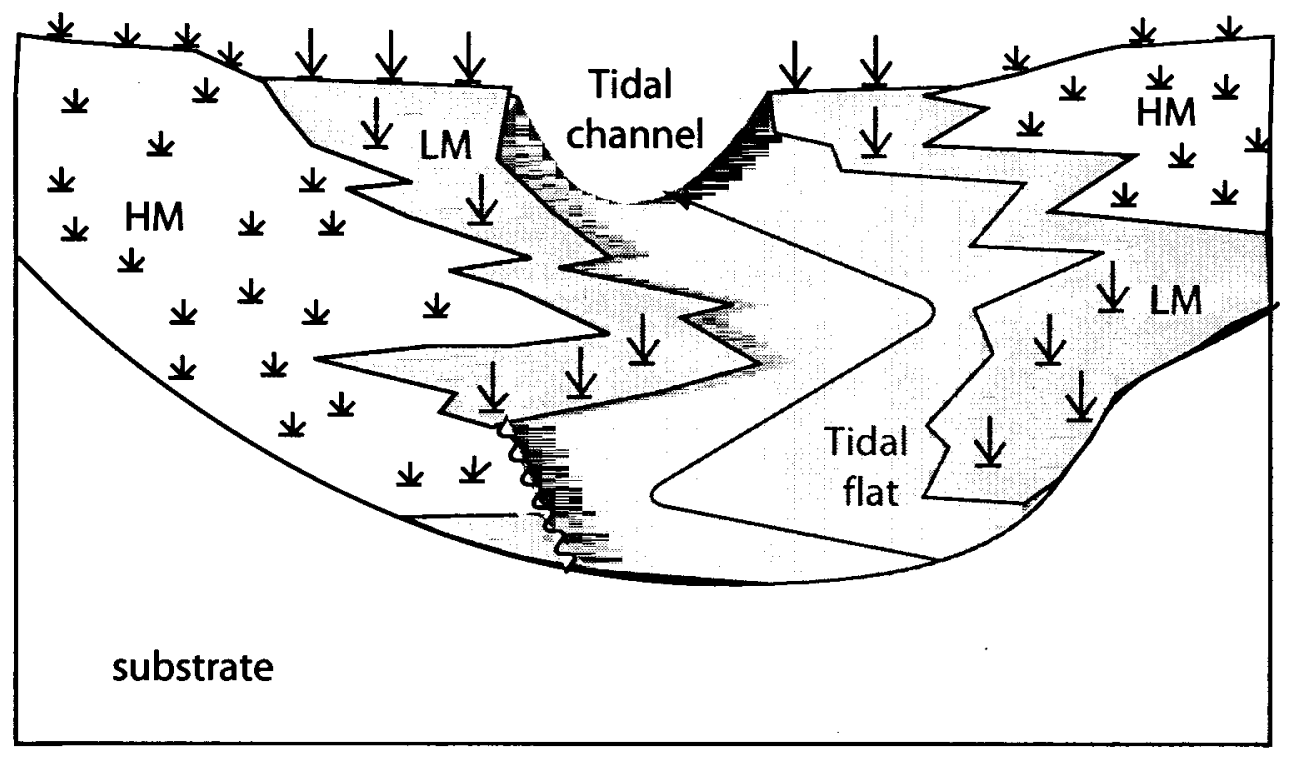

Figure 1.5 Schematic cross-section of a fringing fluvial marsh. The migration of the tidal channel and aggradation of the marsh in reponse to sea-level rise results in a more complex stratigraphy, including some erosional surfaces. 
foraminiferal zones distinguish low and high marsh. In addition, both foraminiferal zones are subdivided, so four foraminiferal zones exist to characterize peat. The foraminiferal zones are generally related to the floral zones, but offer better vertical resolution with respect to MHW, especially for the higher high marsh. The highest part of the marsh, or the "leading edge", is characterized by a monospecific assemblage of Jadammina macrescens (Scott and Medioli, 1978). This " $1 \mathrm{a}$ " zone is identified in peats around the Gulf of Maine and Maritimes and may be especially vertically restricted (Scott and Medioli, 1978; Scott and Medioli, 1980; Gehrels et al., 1996). Its vertical range is as little as $0.05 \mathrm{~m}$ (Scott and Medioli, 1978), but is more typically $\sim 0.30 \mathrm{~m}$ (Gehrels et al., 1996). Identification of this zone in combination with an $\mathrm{AMS}{ }^{14} \mathrm{C}$ date yields a high resolution sea-level index point. A series of such points are used to reconstruct a sea-level curve at a location. With the inclusion of appropriate error estimates, curves from several areas may be compared and true differential sea-level change measured.

Table 1.1 Foraminiferal zones (modified from Gehrels, 1994).

\begin{tabular}{cl}
\hline Zone & \multicolumn{1}{c}{ Foraminifera } \\
\hline $1 \mathrm{a}$ & Jadammina macrescens \\
\hline $\mathrm{b}$ & $\begin{array}{l}\text { Jadammina macrescens } \\
\text { Balticammina pseudomacrescens } \\
\text { Tiphotrocha comprimata } \\
\text { Trochammina inflata }\end{array}$ \\
\hline $2 \mathrm{a}$ & $\begin{array}{l}\text { Miliammina fusca } \\
\text { Trochammina inflata }\end{array}$ \\
\hline $2 \mathrm{~b}$ & $\begin{array}{l}\text { Miliammina fusca } \\
\text { Ammotium salsum } \\
\text { Pseudothurammina limnetis }\end{array}$ \\
\hline
\end{tabular}


Construction of a sea-level change record from salt-marsh sediments typically follows one of two approaches: 1) analysis of a continuous record from a single core, or 2) analysis of basal peats along a transect across the field site. In addition, the investigative approach and analysis of the record may focus on resolution of high-frequency events or on description of long-term trends. The debate between 'wigglers' who focus on shortterm decadal to centennial events and 'smoothers' who focus on millenial trends is summarized by Belknap and Kraft (1977) and Gehrels (1999). The single-core analysis technique is preferred for reconstruction of high-frequency signals. A single core is thought to provide relatively continuous environmental information (with the exception of hiatuses associated with erosion) (Varekamp et al., 1992; van de Plassche, 1991; van de Plassche, 1998). Analysis of basal peats provides spatially discontinuous information, but avoids the uncertainties introduced by of autocompaction. Criticism of single-core analysis centers on the high degree of spatial variability in a marsh that may lead to environmental shifts in the core unrelated to climate or sea-level change, and the introduction of vertical uncertainty due to autocompaction (Kelley et al., 2001). The criticism of reconstructions from basal peat analysis is that fine detail in the record is not discernible. Reconstructions of late Holocene sea-level change from the eastern coast of North America reflect the implementation of both these approaches.

Salt-marsh Records. Detailed study of marshes along the eastern North American coast indicates significant variations in the timing and rate of mid- to late Holocene sea-level rise from north to south. Salt marshes in the Carolinas, Delaware, New Jersey, Connecticut, the Gulf of Maine, and the Maritimesp provide records of late Holocene sea 
level change at dozens of locations on this passive margin. In general, the trend along this coast reflects the variable influence of isostatic adjustment with distance from the former ice margin (Gornitz, 1995).

In the mid-Atlantic, the sea-level reconstruction for southeastern Delaware has not significantly varied from the curve published by Belknap and Kraft (1977). This reconstruction indicates a decrease in the rate of sea-level rise along this coast during the late Holocene. At a millenial scale, this trend is also recognized in sea-level reconstructions for Connecticut (van de Plassche, 1991; Thomas and Varekamp, 1991) the Gulf of Maine (Belknap et al. 1989; van Heteren et al, 1996; Gehrels et al., 1996), and the Maritimes (Scott and Greenberg, 1983). In the Gulf of Maine, an increase in the tidal range with higher sea level influences the shape of sea-level curves and must be accounted for to compare the data to other locations (Scott and Greenberg, 1983; Gehrels et al., 1996). When this trend is removed from the records, evidence for differential isostatic rebound remains in the different gross trends of the reconstructions. There is not evidence supporting neo-tectonic activity within the Gulf of Maine (Gehrels, 1994; Gehrels et al., 1996). The Connecticut and Maine records indicate that there is no differential late Holocene sea-level change along transects parallel to the former ice margin, providing justification for investigation along a perpendicular transect.

Recent salt-marsh work in the northeast has focussed on investigating centennial or shorter fluctuations in the rate of sea-level change as a reflection of climate change. High-resolution ice-core records from Greenland provide evidence for centennial-scale climate fluctuations during the late Holocene (Mayewski et al, 1994). High-resolution (usually single core) records from Connecticut salt marshes are interpreted to reflect 
changes in the acceleration of sea-level rise that may be correlated to these climate events (Thomas and Varekamp, 1991; Varekamp et al., 1992; van de Plassche et al., 1998; van de Plassche ). Disagreement regarding the interpretation of these records centers on the high spatial variability of the marsh surface, and the complex interplay of local, regional, and eustatic processes influencing development of a salt marsh (Varekamp et al., 1999; Kelley et al., 2001; van de Plassche, 2001). These exchanges highlight the necessity of multiple hypotheses to explain marsh stratigraphy, and emphasize the influence of different methodologies to the interpretation of salt marshes.

High-resolution salt-marsh peat analysis is being developed to link salt-marsh records to tide-gauge records (Gehrels et al., 2001). Due to global warming in the twentieth century, steric ocean expansion is predicted to contribute to rising sea level (Wigley and Raper, 1987). This effect is also predicted to lead to acceleration in the rate of sea-level rise (IPCC, 2002). Current salt-marsh research in well-studied areas focuses on establishing high-resolution records of local sea-level change to discriminate changes in the rate of sea-level rise. An increase in the rate of sea-level change during the $20^{\text {th }}$ century is documented for the Gulf of Maine, and the salt-marsh records agree with tidegauge records for this area (Gehrels et al., 2001).

\section{Tide-gauge Records}

Tide gauges provide detailed historic records of local relative sea-level positions, and are important for evaluating recent and near-future trends in sea-level change. As with salt-marsh records, tide-gauge data reflect the interplay of spatially and temporally variable processes. Quantitative evaluation of tide-gauge data is limited to records 
several decades in length, and the treatment varies with the focus of the investigation. Many potential sources of error were identified for tide-gauge records, including: record duration and completeness, local climatic events (spring freshet), tectonic activity, releveling of local vertical datum, and limited spatial distribution (Douglas, 2001). Although these factors may render tidal data less than optimal for determining eustatic sea-level rise, they may not interfere with determination of spatial variability in sea-level change over a relatively small region. Comprehensive evaluation of existing tide-gauge records was completed by Pirrazoli (1991) and Emery and Aubrey (1991). Tide-gauge data for New England and the Maritimes constrained contours of vertical uplift associated with isostatic rebound (Emery and Aubrey, 1991). This work, and other regional research, is discussed more fully in Chapter 4. Since the inception of the TOPEX/POSEIDON program, the study of eustatic sea-level change has begun to transition away from tide-gauge records and toward satellite altimetry (Nerem and Mitchum, 2001). It seems likely that the future study of tide-gauge data will focus on determining differential rates of local change with respect to the satellite-deduced rate of eustatic rise.

\section{Sea-level Change around Newfoundland}

Sea-level change around Newfoundland since the late Pleistocene was strongly controlled by glacioisostatic adjustment. The LGM (Last Glacial Maximum) and Pleistocene - Holocene history of glacial retreat and sea-level change is not completely documented. The timing and magnitude of sea-level change is strongly dependent on the glacial history of the region. Although two models for the configuration of the 
Laurentide ice sheet at the LGM have been advanced, the "maximum" model is now favored over the "minimum" (Denton and Hughes, 1981). By the "maximum" reconstruction, Newfoundland was completely glaciated during the LGM by a combination of Laurentide ice and local ice caps (Batterson, 2001). During deglaciation, ice retreated rapidly in the Gulf of St. Lawrence, and Newfoundland was quickly isolated from the Laurentide ice sheet.

Numerical Predictions. Model results vary significantly, depending on the spatial and temporal resolution used. An early model broadly predicted that most of the Newfoundland coast has a type B sea-level curve, and that the Northern Peninsula has a type A sea-level curve (Quinlan and Beaumont, 1981). Predictions of variations in the sea-level history are based on the passage of a decaying marginal forebulge from southeast to northwest (Figure 1.6). This migrating, decaying forebulge has been inferred from records in the Gulf of Maine, but the rate of movement is not well constrained (Barnhardt et al., 1995) (Figure 1.7). As the forebulge moved across Newfoundland, the region above the forebulge was temporarily elevated. For type B sea-level histories, this temporary uplift occurred during the highstand phase; the fall to the lowstand marks the passage of the forebulge through the area. For areas with type A sea-level histories, the passage of the forebulge is not completed, and the region is still being uplifted.

Pleistocene-Holocene Records. Previous field research provides a framework for consideration of the model predictions. Early to mid-Holocene sea-level histories around Newfoundland are relatively well studied (summarized by Liverman, 1994; Shaw and Forbes, 1995). For most of the island, radiocarbon dated shells from emergent beach deposits define a post-glacial highstand of variable elevation (Liverman, 1994). Sea level 

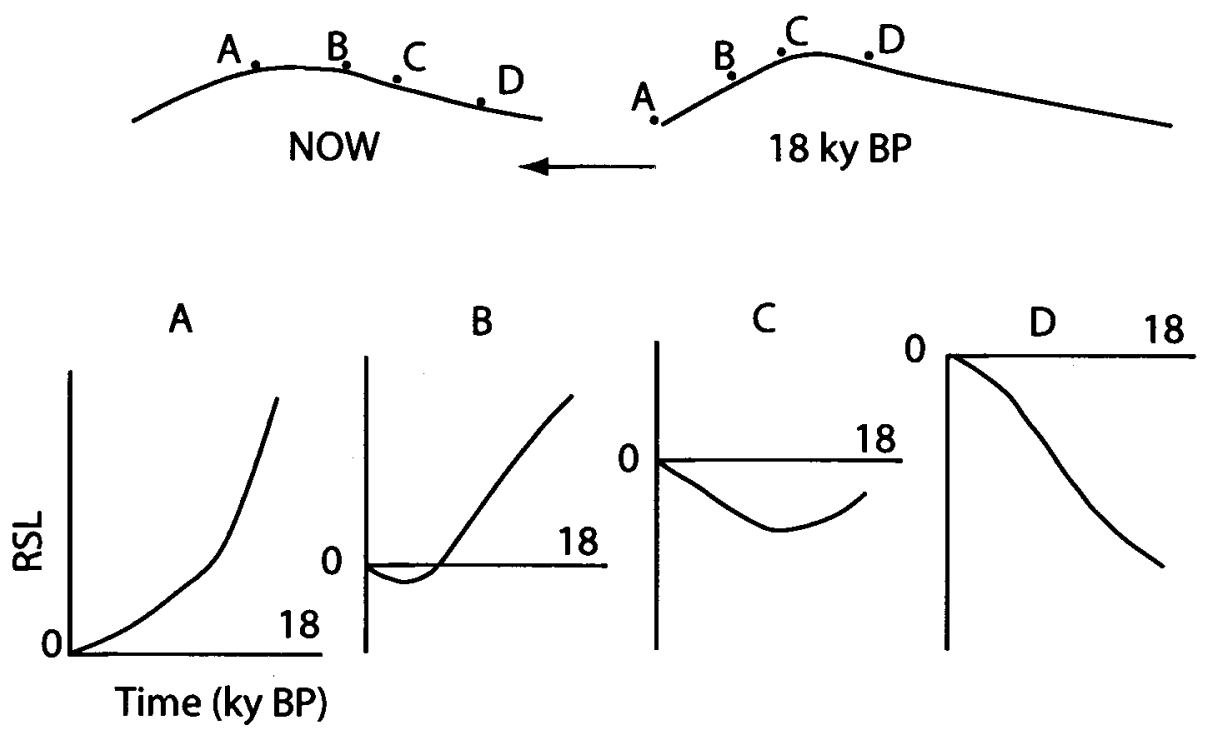

Figure 1.6 Predicted sea-level curves at four locations affected at different times by the migration of a proglacial forebulge (from Quinlan and Beaumont, 1981). 


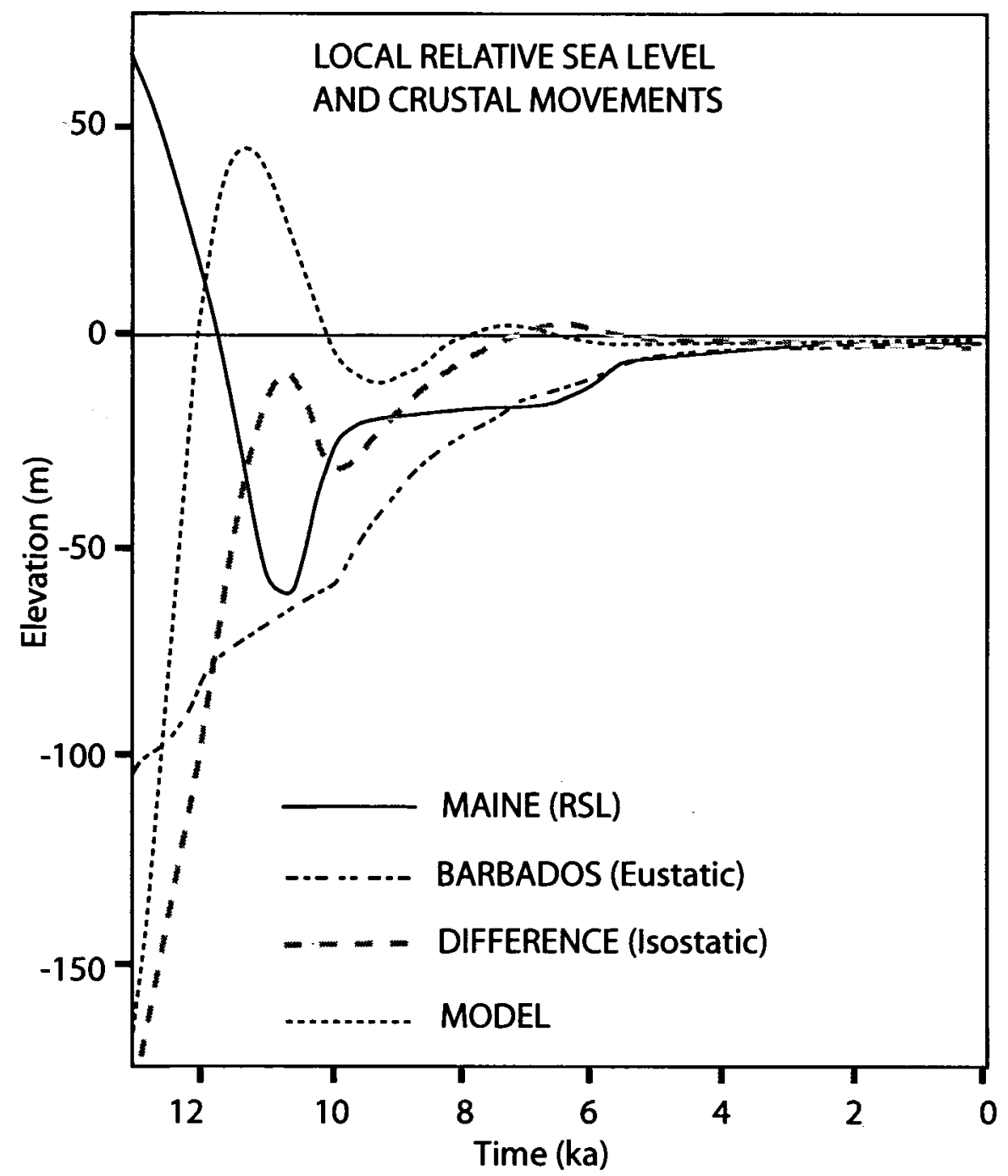

Figure 1.7 Comparison of a local relative sea level curve in a previously glaciated area (Maine) with a eustatic sea-level curve (Barbados) (from Barnhardt et al., 1995). The difference between these two curves is attributed to glacioisostatic adjustment, which may be approximated by a damped oscillator model. 
subsequently fell, passing below its present elevation during the late Pleistocene through early Holocene. This sea-level fall is time-transgressive across the island; sea level passed below present MSL earlier around the southeastern end of the island and progressively later toward the northwest (Shaw and Forbes, 1995). At present, sea level continues to fall around the distal end of the Northern Peninsula while rising from the lowstand around the rest of the island. More complex sea-level histories have been suggested for the southern end of the Northern Peninsula (Grant, 1994). One possible sea-level history would be a fall to present MSL during the mid-Holocene, a slight rise above present MSL during the mid-Holocene, and subsequent fall to present (Grant, 1994). However, this type of sea-level change is not well defined, especially chronologically. The limited research to date does not concur with numerical model predictions for sea-level trends. Detailed reviews of local sea-level reconstructions are site-specific and are included in subsequent chapters. 


\section{Chapter 2}

\section{METHODS}

\section{Field Methods}

Five locations were selected for study: Hynes Brook (Port-au-Port peninsula), St. Paul's Inlet, Village Cove (New World Island), Deadman's Bay, and Placentia (Figure 2.1). At each field location, as many as a dozen preliminary hand cores were collected and logged to determine the gross stratigraphy of the marsh. Several basal peat samples from preliminary cores were also informally examined using a portable binocular microscope and headlamp to determine whether foraminifera were present. Cores for analysis in the lab were selected by considering the results of preliminary coring, and were collected along one or more transects at each field location. Using an Eijkelkamp (Dutch) hand corer, cores were removed and immediately cleaned and photographed. Cores were subsequently placed in a plastic-wrap-lined length of PVC, sealed, wrapped in another layer of plastic wrap, and wrapped in a layer of aluminum foil. Major stratigraphic boundaries (e.g., depth to basal peat) were noted at the time of collection to correct for potential disturbance during travel. In the lab, cores were opened and described on the Sedimentology Lab core log. Descriptions of the cores are included in Appendix A. Cores were subsampled for foraminiferal analyses and AMS ${ }^{14} \mathrm{C}$ samples.

Using a Sokkia Total Station, each core was leveled with respect to either an established datum (benchmark) or local high water as measured in the field that day. Because of the remote location of the field sites, establishment of a common datum among field areas is a problem. With one exception (St. Paul's Inlet), transects could not be related to an established benchmark or other datum. At all field sites, I measured the 


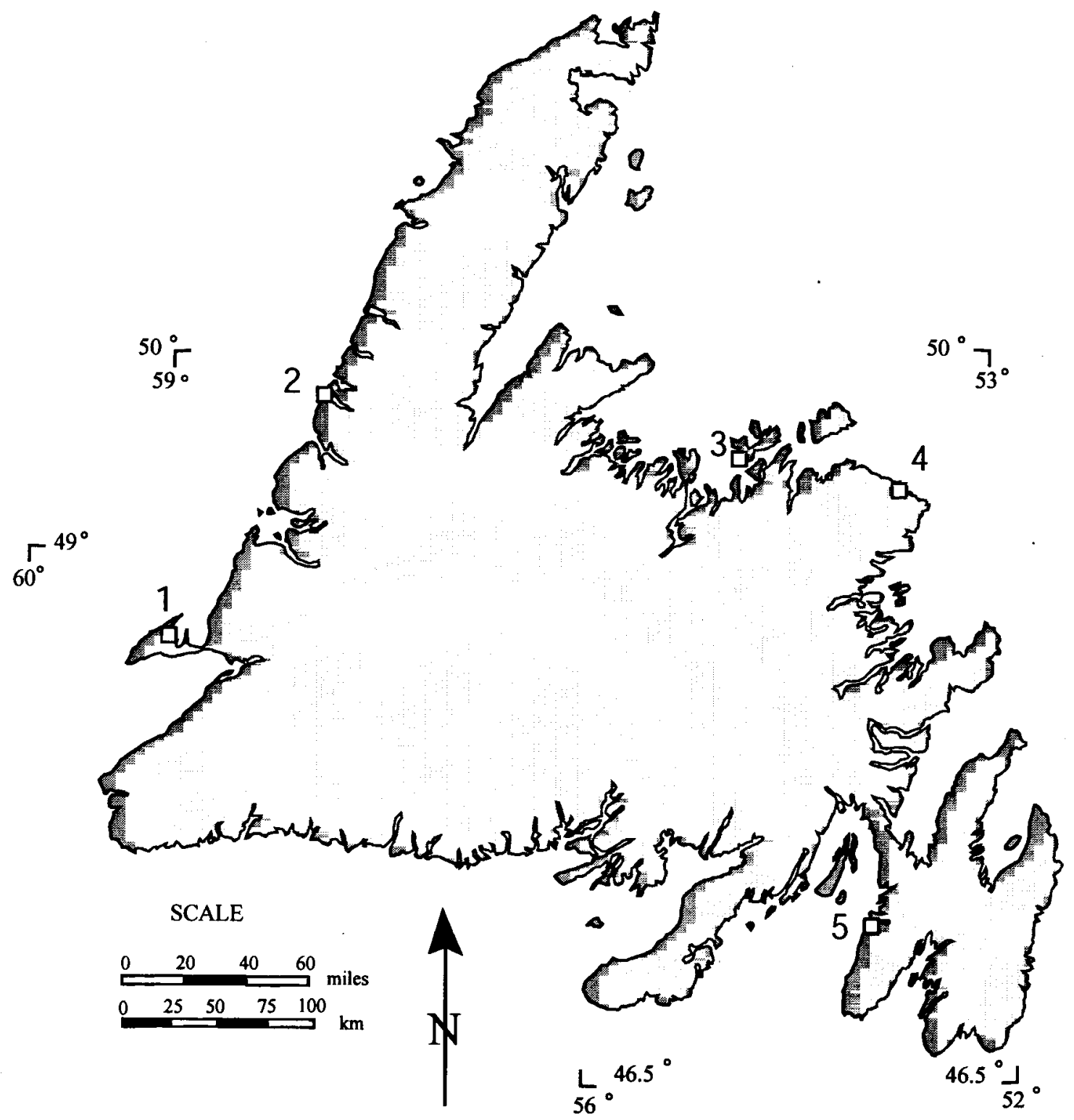

Figure 2.1 Location map showing salt marsh sites: 1) Hynes Brook, 2) St. Paul's Inlet, 3) Village Cove, New World Island, 4) Deadman's Bay, and 5) Southeast Arm, Placentia. 
high and low water elevations proximal to the transects. However, there is disagreement between the measured and predicted tidal ranges (Table 2.1). The discrepancies between the predicted and measured tidal ranges are attributed to several factors: (1) Many of the water-level measurements were made in the backbarrier area, distant from open water. The tidal range is attenuated in a backbarrier/estuarine environment, but most of the 'loss' results from a delayed ebb tide (Lincoln and FitzGerald, 1988). The high-water level is not substantially decreased (Lincoln and FitzGerald, 1988). (2) The predicted tidal ranges are not for any of the actual field locations, and may be for 'subordinate stations' as distant as 30 or $40 \mathrm{~km}$ from the field site (Figure 2.1, Table 2.1). (3) To confound this, the predictions are based on different reference stations. For each reference station, the depth below mean sea level (MSL) is given for the tidal prediction datum.

Table 2.1 Predicted (Canadian Hydrographic Service, 1999) and measured water tidal ranges near five main field sites. Refer to Figure 2.1 for location of field sites and subordinate stations.

\begin{tabular}{lccccc}
\hline Field site & $\begin{array}{c}\text { Subordinate } \\
\text { station }\end{array}$ & $\begin{array}{c}\text { Reference } \\
\text { station }\end{array}$ & $\begin{array}{c}\text { Predicted tidal } \\
\text { range }(\mathrm{m})\end{array}$ & $\begin{array}{c}\text { Measured tidal } \\
\text { range }(\mathrm{m})\end{array}$ & $\begin{array}{c}\text { Difference } \\
(\mathrm{m})\end{array}$ \\
\hline Hynes Brook & Port-au-Port & Harrington Hbr. & 0.81 & 0.49 & 0.32 \\
St. Paul's Inlet & Portland Cove & Harrington Hbr. & 1.44 & - & - \\
New World Isl. & Exploits L.H. & Halifax & 0.94 & - & - \\
Deadman's Bay & Valleyfield & Halifax & 0.59 & 0.11 & 0.48 \\
Placentia & Argentia & Argentia & 1.5 & 0.75 & 0.8 \\
\hline
\end{tabular}

Despite these complications, it is imperative to define a common datum for purposes of comparison among records. Water-level predictions at the five subordinate stations are plotted for two-week periods during which field work was conducted at the field locations. Based on this two-week period, which encompassed both a neap and spring tide, MHW at each subordinate location was calculated. The high tide measured at each site is related to a predicted high tide at the appropriate subordinate station (Figure 
2.1). In other studies, MHW was determined by locating the boundary between Spartina alterniflora and Spartina patens (Gehrels, 1994). However, this was not possible due to the absence of $S$. alterniflora at most field sites. At all sites, the timing of the measured high tide coincided with a high tide close to the approximate MHW. The differences between MHW and the daily high water are minimal (Figure 2.2, Table 2.2). Given this minimal difference, the high water measured at each site is taken to represent MHW at that location. The vertical error introduced by this assumption may be estimated by multiplying the percent difference between actual and 'daily' MHW by the measured tidal range at each field location (Table 2.3).

Table 2. 2 Difference between measured high water and projected MHW based on predicted water levels.

\begin{tabular}{ccc}
\hline $\begin{array}{c}\text { Subordinate } \\
\text { station }\end{array}$ & $\begin{array}{c}\text { Difference of measured HW } \\
\text { from projected MHW }\end{array}$ & $\begin{array}{c}\text { Difference as a percent of } \\
\text { predicted tidal range }\end{array}$ \\
\hline Port-au-Port & $-0.06 \mathrm{~m}$ & 7.4 \\
Portland Cove & $-0.10 \mathrm{~m}$ & 6.9 \\
Exploits L.H. & $+0.12 \mathrm{~m}$ & 12.8 \\
Valleyfield & $-0.05 \mathrm{~m}$ & 8.5 \\
Argentia & $-0.06 \mathrm{~m}$ & 4 \\
\hline
\end{tabular}

Table 2.3 Estimated elevation uncertainty due to approximation of MHW at field location.

\begin{tabular}{lc}
\hline Field site & Estimated vertical error $(\mathrm{m})$ \\
\hline Hynes Brook & 0.04 \\
St. Paul's Inlet & 0.10 \\
New World Isl. & 0.12 \\
Deadman's Bay & 0.01 \\
Placentia & 0.03 \\
\hline
\end{tabular}

\section{Laboratory Methods}

\section{Foraminiferal Analysis}

Samples were prepared for foraminiferal analysis by removing $\sim 1 \mathrm{cc}$ of peat from the center of a core. Exact volume of the subsample was determined by displacement. The sample was wet-sieved through $200 \mu$ (to remove coarse material) and $63 \mu$ screens 

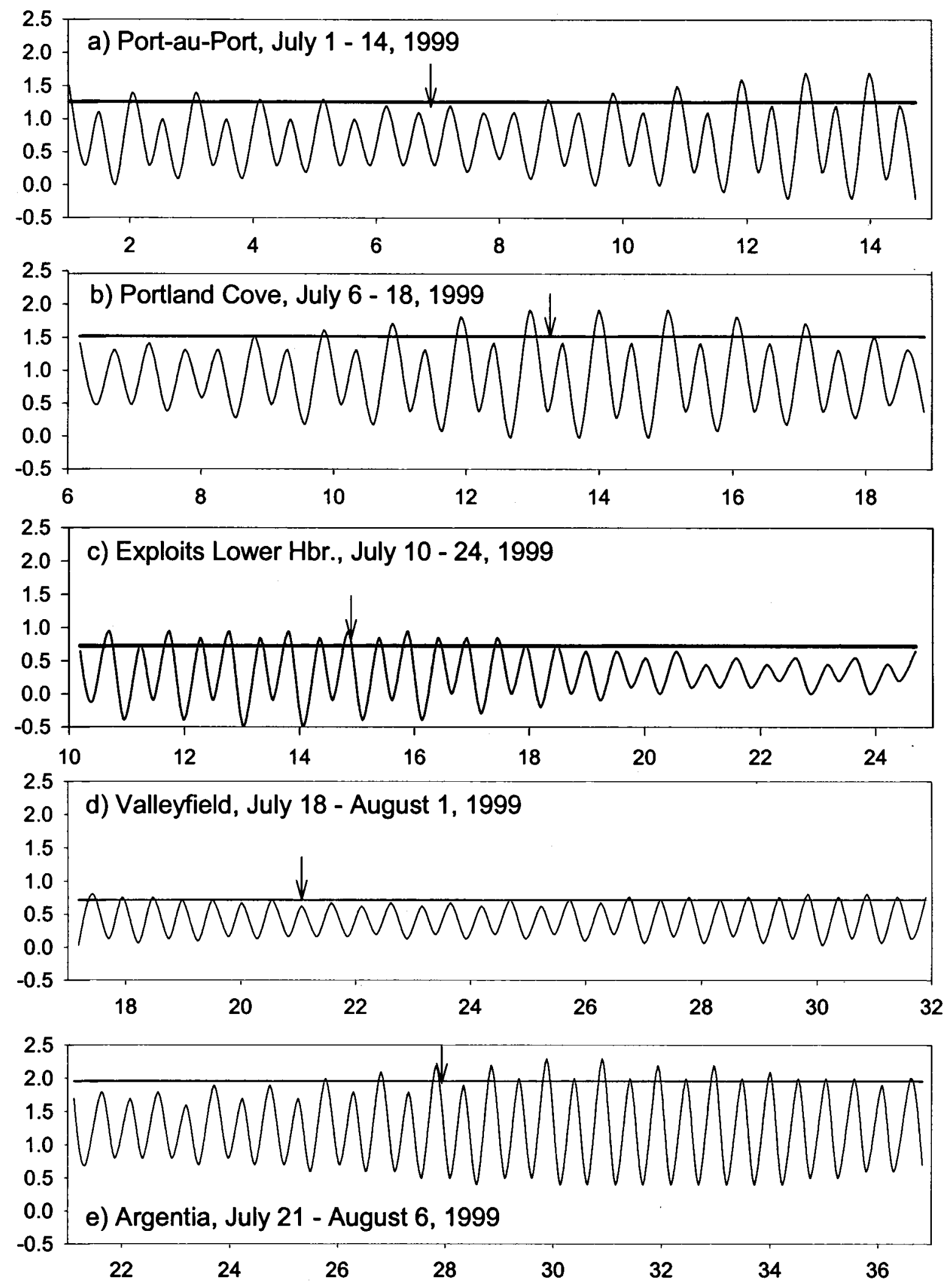

Figure 2.2 Predicted water level variations at five subordinate stations over a two week period. Horizontal line indicates apprximate $\mathrm{MHW}$ at each location. Arrows indicate high water measured. 
and transferred to a $500 \mathrm{ml}$ beaker. Samples were allowed to settle in this beaker, and floating organic material was carefully decanted from the beaker if present. Finally, the sample was split in a wet-splitter by discharging the sample from a beaker into the wetsplitter 5/6 filled with turbid water and allowing the sample to settle for 2-3 minutes (e.g. Gehrels, 1994, Figure 1.11). A 1/8 split was removed from the splitter for initial analysis. The sample was always removed from the section of the wet-splitter diagonally opposite the outflow to minimize the chance of sample removal.

Samples were examined in a pollen-counting tray using a Wild-Heerbrug dissecting microscope. Foraminifera species were identified by comparison to reference collections obtained from Maine marshes and by comparison to published assemblages for the Maritimes and other high-latitude marshes (Scott and Medioli, 1978, 1980; Gehrels, 1994; Thomas and Varekamp, 1991; Saffert and Thomas, 1998). Tim Patterson (Carleton University) and Jean-Pierre Guilbault assisted with the identification of some rare species. Counts reaching a total of 100 foraminifera per split are considered statistically valid. If 100 foraminifera were not in the initial $1 / 8$ split, the remaining $7 / 8$ of the sample were re-split to obtain a $7 / 64$ split. Foraminiferal counts for each sample are included in Appendix B. Examples of different species were picked from each marsh. Representatives of each species were imaged using the scanning electron microscope (SEM) in Murray Hall. SEM images are included in the Systematic Taxonomy (Appendix B).

At each field site, surface samples were collected along one or more transects. Samples $\sim 1 \mathrm{cc}$ were cut from the marsh surface and preserved in a Rose Bengal formalin mixture buffered with baking soda (following Gehrels, 1994). Rose Bengal 
stains living or recently (within a few weeks) living organisms. In the lab, the samples were partially dried in a hood to remove excess liquid and return them to their approximate natural moisture. The exact volume of the sample was then determined by displacement. Surficial samples were prepared for analysis following the procedure described above for core samples.

\section{AMS ${ }^{14}$ C Samples}

Material for AMS ${ }^{14} \mathrm{C}$ dates was selected from the cores during initial core description. Detrital grass, leaf, and bark fragments (where necessary) were removed from the core, washed in deionized water, and dried overnight at a temperature of $40^{\circ} \mathrm{C}$. Samples were weighed on the Mettler balance in the lab and sealed in small plastic bags for submission to the NSF AMS facility at the University of Arizona. Two samples were submitted to ISOTRACE. All ages were calibrated using CALIB 4.3 from the University of Washington (Stuiver and Reimer, 1993). Published ${ }^{14} \mathrm{C}$ ages were also calibrated in order to produce data with a consistent temporal reference frame. The calibrations of published data were completed using information in publications; in many cases, insufficient data were published and 'standard' numbers were used to complete the calibration. This may be especially true for the calibration of marine shells. Radiocarbon dating results are summarized in Appendix D.

\section{Tide-gauge Analysis}

Tide-gauge data were downloaded from the Permanent Service for Mean Sea Level (PSMSL) website, http:/, www.pol.ac.uk/psmsl. Historic rates of local relative 
sea-level change for each site were initially determined using the linear regression feature of MSExcel. The linear regression was only performed on relatively continuous records. An on-line wavelet analysis tool available through the University of Colorado (http://ion.researchsystems.com/IONScript/wavelet/) was used to perform wavelet and evolutionary spectral analyses. This interactive analysis allows one to determine the wavelet parameters (shape, scale), pad the dataset with zeroes to remove edge effects, and show the significance of the wavelet/spectrum versus white or red noise.

A more sophisticated method used "extract", a MATLAB subroutine written by David Meeker (UNH), to define annual and saros cycle contributions to records of sufficient length and completeness. This MATLAB subroutine seeks to identify sinusoidal components in a timeseries at a user-specified periodicity. De-trended data from Harrington Harbour were analyzed by this routine to determine what periodicities influenced the record. The results indicated three periodicites of varying amplitudes. Using MSExcel, a synthetic record was created based on these periodicities and amplitudes with the addition of white noise. The synthetic record was run through the wavelet/spectral analysis tool to determine the optimal settings for extraction of the known periodicites embedded in the record.

\section{Definition and Description of Lithologic Units}

Five generalized lithologic units were recognized in cores: freshwater, transition, higher high marsh (HHM), high marsh (HM), along with a variety of substrate lithologies. Descriptions of the units are based on both floral and faunal assemblages in surficial and core samples. Low marsh, characterized by dominant Spartina alterniflora, 
was not recognized at any field location. There is significant local variation among lithologic units. Foraminiferal zonations at each field location are used to define more specific zones. General descriptions of each unit follow. A more detailed description of the foraminiferal zones follows as a separate section.

\section{Freshwater Peat}

Freshwater peat is characterized by a detrital texture and the absence of foraminifera. Detrital leaf and bark fragments, pine cones and needles, small twigs or branches, or pieces of woody roots are characteristic of this unit. This peat is often very dark brown (10YR 2/2) to black in color. Modern vegetation associated with the freshwater fringe of a marsh includes Iris versicolor, Carex sp., Solidago sempervirens, numerous upland grass species, and freshwater bog flora (e.g. Sphagnum species). Iris versicolor is reported to represent highest high water level (HHWL), the upper limit of marine influence (Brookes et al., 1985). The root bulbs of Iris versicolor are very yellow (2.5 Y 8/4) and fibrous, and on first examination may be confused with $S$. alterniflora.

\section{Transition Peat}

This unit has previously been defined as a zone between dominant Spartina patens and dominant Spartina alterniflora (Gehrels, 1994). It is used in a different sense in this study. Transition peat is characterized by fibrous texture, dark color, and low abundance of foraminifera $(<100 / \mathrm{cc})$. Roots and rhizomes associated with this peat are typically from Juncus species, probably J. gerardii or J. balticus. Modern vegetation associated with this peat includes these Juncus species, Solidago sempervirens, Potentilla 
species, and some sedges. Foraminifera present are usually limited to Jadammina macrescens and Balticammina pseudomacrescens.

\section{Higher High Marsh Peat}

Higher high marsh (HHM) peat has a characteristic fibrous texture, a dark brown (10 YR 3/2) or dark reddish-brown (5 YR 2.5/2) color, and moderately abundant foraminifera $(400-800 / \mathrm{cc})$. Roots and rhizomes characteristic of this peat are similar to transition peat, including Juncus species. Modern vegetation associated with the peat includes Juncus, S. sempervirens, and Potentilla species. The foraminiferal assemblage is also similar to that in transition peat, but the foraminifera are more abundant $(>600 / \mathrm{cc})$ and may also include Miliammina fusca and Trochammina inflata.

\section{High Marsh Peat}

High marsh peat (HM) has a very fibrous texture, a brown to dark brown color, and abundant (>800/cc) foraminifera. Juncus, Spatina patens, and Distichlis spicata roots and rhizomes may be identified in association with this peat. These plants characterize the surficial HM zone, while Eleocharis species and Triglochin maritima occur at some locations. Foraminifera associated with this zone are $J$. macrescens, $B$. pseudomacrescens, M. fusca, T. inflata, T. comprimata, and Trochamminita salsa. 


\section{$\underline{\text { Substrate }}$}

The peat overlies a wide variety of substrates. Barrier sands are characterized by well-sorted fine to very fine grains of variable composition, typically dominantly quartz. Tidal flat deposits are characterized by poorly-sorted gravelly sandy muds with shell fragments. Glaciomarine deposits are compact, massive muds of silt and clay varying in color from grey to reddish-brown depending on locality and degree of oxidation. Rarely, the peat was inferred to directly overlie bedrock of unknown composition. Roots and rhizomes of the overlying peat typically penetrate to varying depths in the substrate, so the contact may be gradational. 


\section{Chapter 3}

\section{TIDE-GAUGE RECORDS}

\section{Introduction and Previous Work}

Tide-gauge records provide information about local relative sea-level change on a decadal to centennial scale. The records, although temporally limited to about one century, provide much higher resolution of sea levels than is possible from study of saltmarsh records. Sampling methods and length of the record determines whether daily, weekly, monthly, annual, or decadal variability is resolved. Secular variations in the water levels may also be extracted. These changes are related to local relative sea-level change, and comparison of records from a region may indicate variable trends related to long-term isostatic adjustment.

Recent studies pair tide-gauge records with GPS data to determine variable isostatic rebound and resolve rebound motions three-dimensionally (Mitrovica et al., 2000). Tide-gauge trends delineate variable sea-level change along the Atlantic coast of the United States and Canada, defining the limit of glacioisostatic adjustment (Gornitz, 1995). Tide-gauge records were also interpreted to show a recent increase in the rate of eustatic sea-level rise, possibly related to global warming. Rates of rise interpreted from tide-gauge trends compared salt-marsh records from the Gulf of Maine and the Maritimes agree well, supporting the idea of an increase in the rate of sea-level rise since 1850 (Gehrels et al., 2001). However, the spatial distribution of tide gauges and the sampling methods may not accurately reflect eustatic sea-level change. A percentage of eustatic sea-level rise is due thermal expansion of the water column (Wigley and Raper, 1987). A comparison of tide-gauge records with TOPEX/Poseidon data indicate that the rate of 
sea-level rise measured by the tide gauges is faster (Cabanes et al., 2001). The discrepancy points to the possibility that thermal expansion is more effective in the shallow areas of continental margins, and that the location of tide gauges biases that data set. If this is correct, true eustatic sea-level change may only be determined from longterm satellite measurement. It is important to note that this discrepancy does not necessarily negate the utility of tide-gauge records; they are the best recorders of local relative sea-level change.

Tide-gauge records from the Maritimes are included in comparisons of sea-level change along the Atlantic coast of North America (Emery and Aubrey, 1991; Gornitz, 1995) (Figure 3.1). Only a few records from Newfoundland are of sufficient duration to use for study of sea-level change. No systematic study of the records from the island has been published since 1990, allowing for an additional decade of data to be analyzed in this project. Analysis of data from Port-aux-Basque and St. John's are interpreted to have opposing trends by Emery and Aubrey (1991) (Figure 3.2). The data are interpreted to show rising sea level at Port-aux-Basques and falling sea level at St. John's. The linear regression used to calculate the rates included all available data, which may explain the difference in trends. Data at Port-aux-Basques are continuous since 1950, but were also collected from 1937 to 1938 . This short, early interval was included in the regression, and biases the results to indicate a trend of falling sea level. These results skew the contours of isostatic adjustment slightly, but broadly agree with predictions for the area based on numerical models (Emery and Aubrey, 1981). 


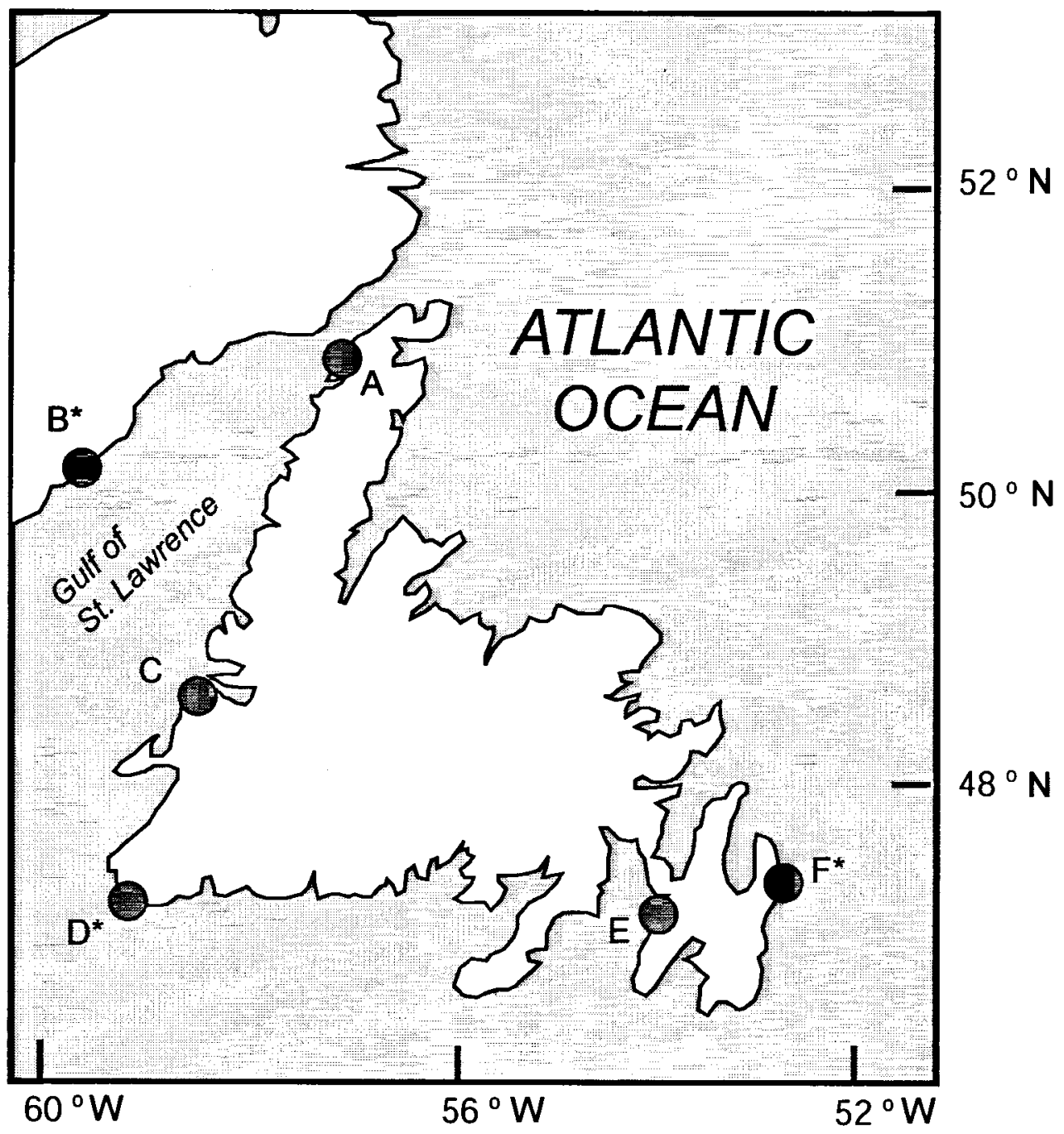

Figure 3.1 Location map of tide gauges evaluated in Newfoundland and Quebec. A: Savage Cove, B: Harrington Harbour, C: Lark Harbour, D:

Port-aux-Basques, E: Argentia, and F: St. John's. Asterisks indicate stations evaluated in previous publications. 

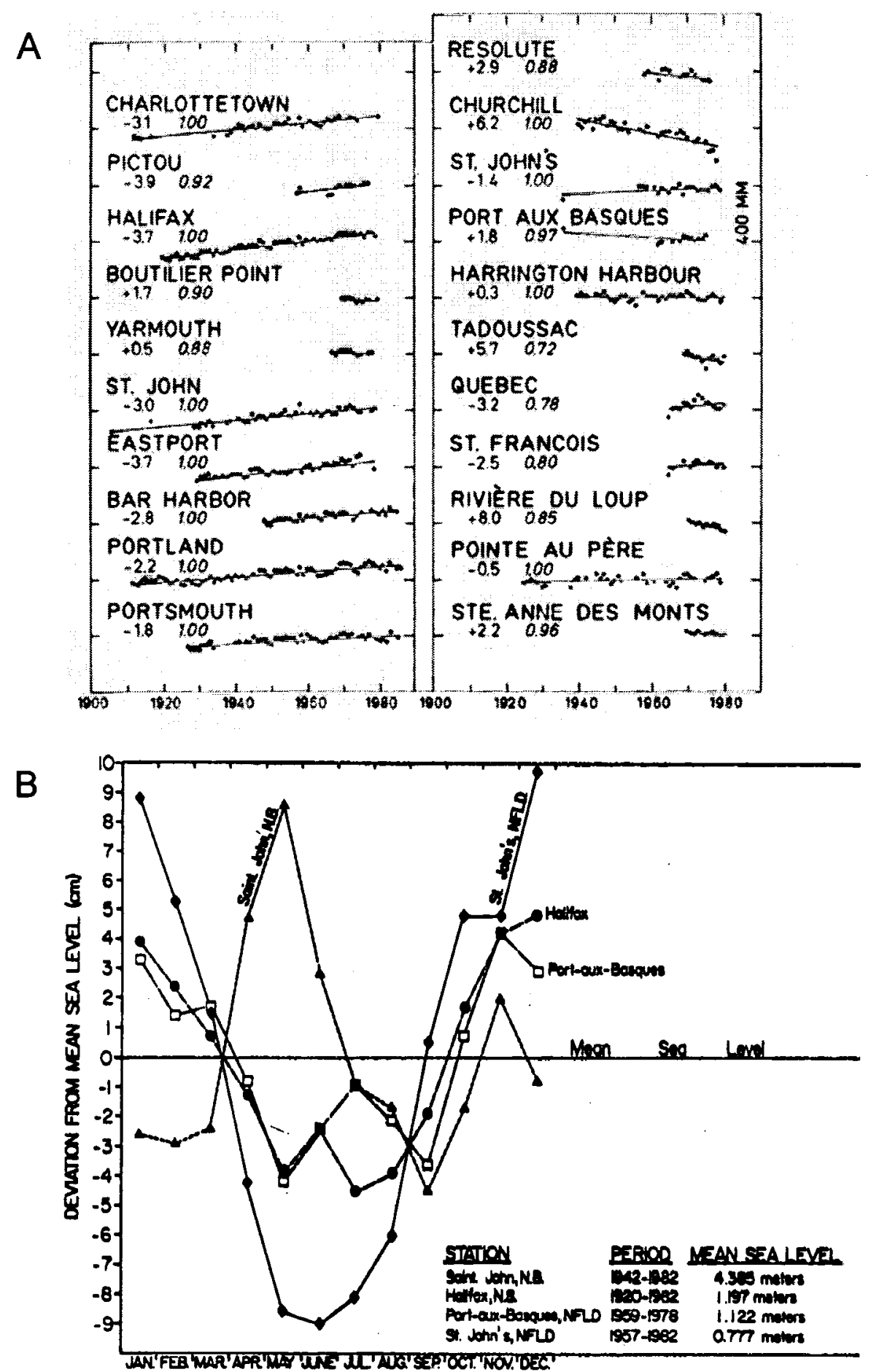

Figure 3.2 Previous water level studies using Maritime tide gauge data. A) Tide gauge data from the Maritimes with linear regressions and rates of change (Emery and Aubrey, 1991). B) Seasonal variations in water level at four tide gauges (El-Sabh and Murty, 1986). 
Analysis of decadal and annual variability in Maritime tide-gauge records revealed that annual cycles account for most of the variability (El-Sabh and Murty, 1986). Three factors: atmospheric pressure, water transport, and changing density of seawater affect records (El-Sabh and Murty, 1986). Decadal cyclicity associated with the saros cycle (lunar cyclicity of 18 years, 11.3 days) is not a major component of the variability, nor are seasonal changes. The annual variability is characterized by lowest water levels during the summer months and highest water levels during the winter (Figure 3.2). The magnitude of this variability is relatively small, on the order of 10-20 $\mathrm{cm}$, compared to tidal ranges of $1-1.5 \mathrm{~m}$.

\section{Results}

I analyzed data from six tide gauges around Newfoundland (Figure 3.1). Data from three locations (Port-aux-Basques, Harrington Harbour (QC), and St. John's) were used in previous studies, but have not been re-examined in the past decade. The duration and completeness of the records varied from station to station, rendering some estimates of sea-level change more reliable than others (Table 3.1). All but one record (Savage Cove) meet the 22-year minimum record length used by Emery and Aubrey (1991). Several analytical methods were used to evaluate cyclical and secular changes in the tidegauge records, including linear regression, evolutionary spectral anaylsis and wavelet analysis. 
Table 3.1 Location and operation of tide gauges evaluated in this study.

\begin{tabular}{lcclcc}
\hline Location & Latitude & Longitude & Years of Operation & $\begin{array}{c}\text { Duration } \\
\text { (years) }\end{array}$ & $\begin{array}{c}\text { Completeness } \\
(\%)\end{array}$ \\
\hline Savage Cove & $51^{\circ} 20^{\prime} \mathrm{N}$ & $056^{\circ} 41^{\prime} \mathrm{W}$ & $1970-1982$ & 13 & 77.6 \\
Harrington Hbr., QC & $50^{\circ} 30^{\prime} \mathrm{N}$ & $059^{\circ} 29^{\prime} \mathrm{W}$ & $1910,1939-1989$ & 51 & 95.4 \\
Lark Harbour & $49^{\circ} 06^{\prime} \mathrm{N}$ & $058^{\circ} 22^{\prime} \mathrm{W}$ & $1963-1988$ & 25 & 66.7 \\
Port-aux-Basques & $47^{\circ} 34^{\prime} \mathrm{N}$ & $059^{\circ} 09^{\prime} \mathrm{W}$ & $1935-1937,1959-2000$ & 42 & 90.1 \\
Argentia & $47^{\circ} 18^{\prime} \mathrm{N}$ & $053^{\circ} 59^{\prime} \mathrm{W}$ & $1972-2000$ & 29 & 88.2 \\
St. John's & $47^{\circ} 34^{\prime} \mathrm{N}$ & $052^{\circ} 42^{\prime} \mathrm{W}$ & $1942,1957-2000$ & 44 & 93.2 \\
\hline
\end{tabular}

\section{Linear Regression Analysis}

Linear regressions through the six tide-gauge records yielded varying trends in the form of $y=m x+b$, where $m$ is the rate of secular change in $m m / y r$. Negative $m$ values indicate falling local relative sea level; positive $\mathrm{m}$ values indicate rising local relative sea level. The portion of the record used for the regression varied, as indicated by the plot of the regression line through the data (Figure 3.3). Only the most continuous data were used for the regression; in some cases, as with St. John's, this excluded a few older values. The values range from $-5.8 \mathrm{~mm} / \mathrm{yr}$ to $+2.3 \mathrm{~mm} / \mathrm{yr}$ (Table 3.2). The estimate of $5.8 \mathrm{~mm} / \mathrm{yr}$ is unreliable due to the short duration of the record, and may over-estimate the rate of change.

Table 3.2 Local relative sea-level change calculated by linear regression analysis of tide-gauge records.

\begin{tabular}{llc}
\hline Location & Years of Operation & $\begin{array}{l}\text { Rate of change } \\
(\mathrm{mm} / \mathrm{yr})\end{array}$ \\
\hline Savage Cove & $1970-1982$ & -5.8 \\
Harrington Harbour & $1910,1939-1989$ & -0.7 \\
Lark Harbour & $1963-1988$ & +0.4 \\
Port-aux-Basques & $1935-1937,1959-2000$ & +2.3 \\
Argentia & $1972-2000$ & +1.6 \\
St. John's & $1942,1957-2000$ & +1.6 \\
\hline
\end{tabular}



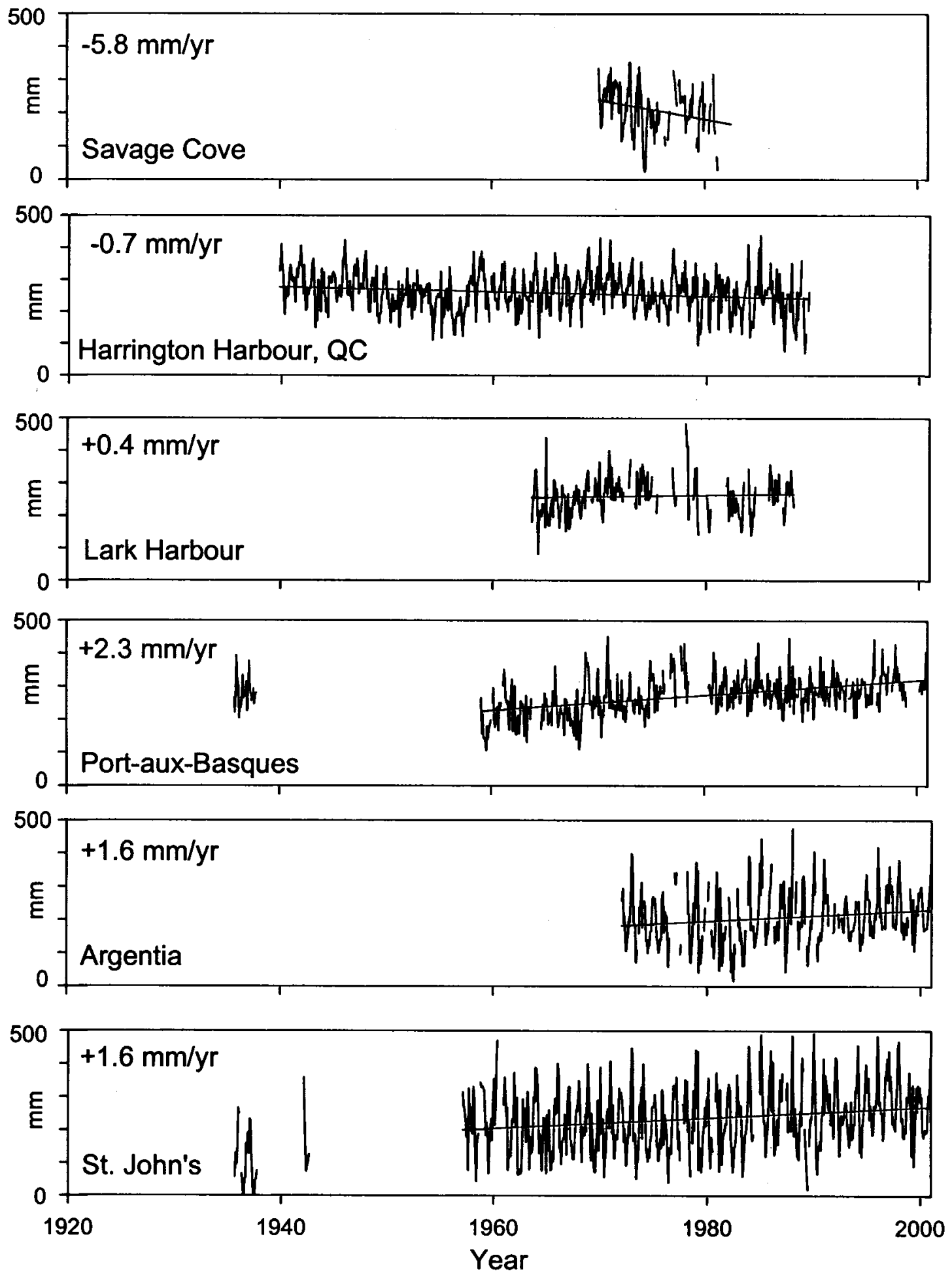

Figure 3.3 Tide gauge records from six sites in Newfoudland and Quebec. Plot shows mean monthly water levels in mm versus local vertical datums. Linear regression through data indicate secular water level change; the rate of this change is shown in $\mathrm{mm} / \mathrm{yr}$ in the upper left corner of each plot. Vertical and temporal axes are of comparable scale in all plots. 


\section{Wavelet and Evolutionary Spectral Analyses}

Spectral analysis of long, continuous tide-gauge data reveal that long-period astonomical cycles influence the tidal records. These periodic variations need to be considered, and removed if possible, to best determine secular changes in the water-level records. Rigorous wavelet and evolutionary spectral analyses of the available data are beyond the scope of this project, but the availability of an on-line spectral analysis tool facilitated a preliminary evaluation of the data. The sensitivity of the on-line wavelet analysis tool was tested using a synthetic tide-gauge record (Figure 3.4). Sine waves with periodicities of 1,6 , and 18 years and varying amplitudes $(30 \mathrm{~cm}$ for the 1 year periodicity, $6 \mathrm{~cm}$ for the 18 year periodicity) were added together. White noise was introduced into the record. This synthetic record was run through the wavelet analysis tool to determine the optimal wavelet configuration for pulling out long-term periodicities.

Three records were chosen for analysis: Halifax, NS; Harrington Harbour, QC; St. John's, NF. Wavelet analyses and evolutionary spectral analyses for each site indicate that only the annual periodicity is common to all three records (Figure 3.35). The Halifax record shows periodicities of $1, \sim 11$, and $\sim 18$ years. The Harrington Harbour record shows periodicities of 1,6 , and $\sim 18$ years. Periodicities of 1 and $\sim 13$ years are found in the St. John's record. 

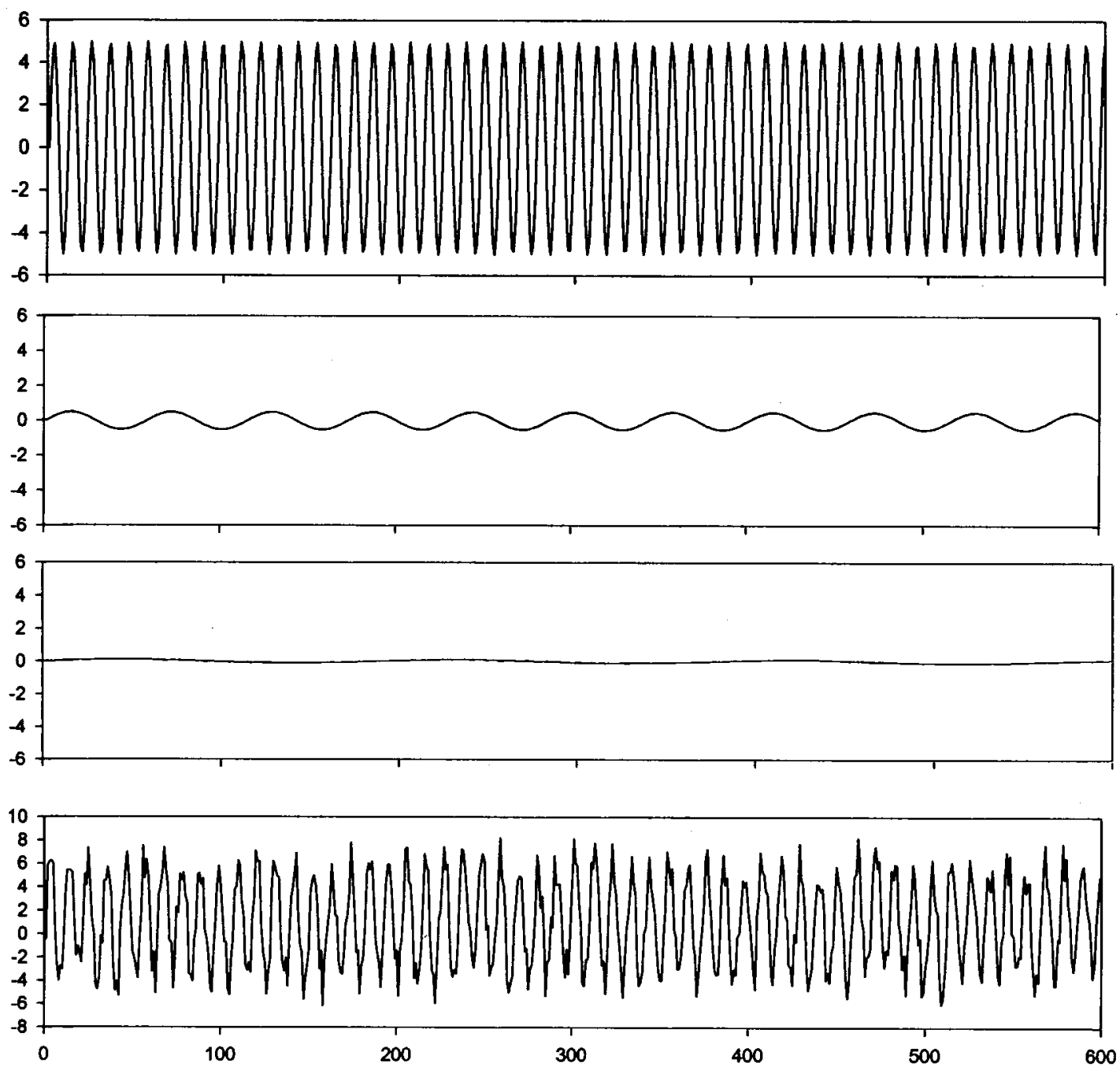

Figure 3.4 a) Sine wave with periodicity of $1 \mathrm{yr}, \mathrm{b}$ ) sine wave with periodicity of 6 years, c) sine wave with periodicity of 18.9 years, d) synthetic record created by adding these sine waves together and introducing white noise. 


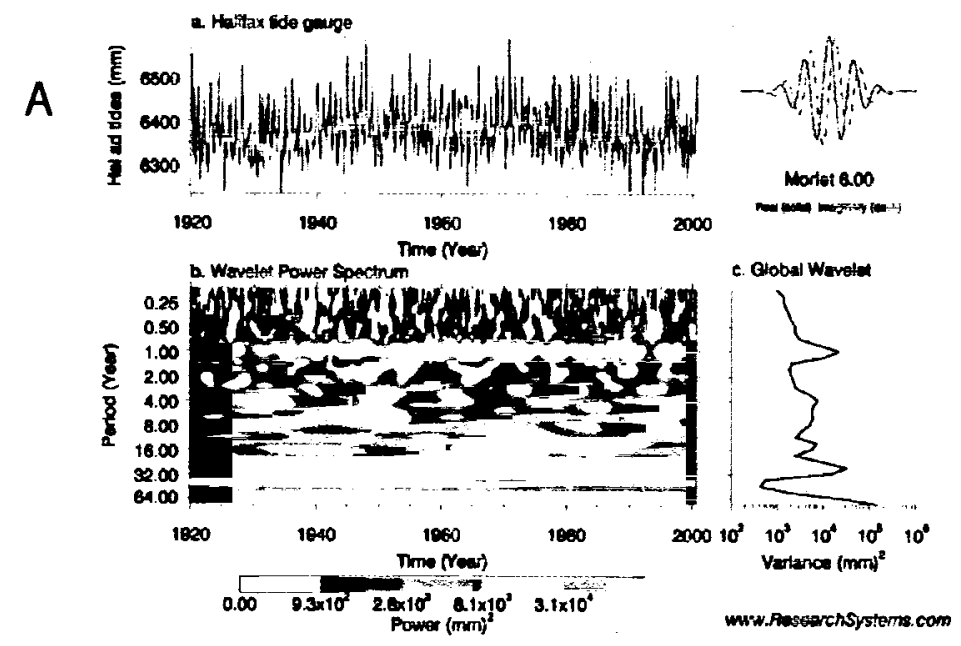

B
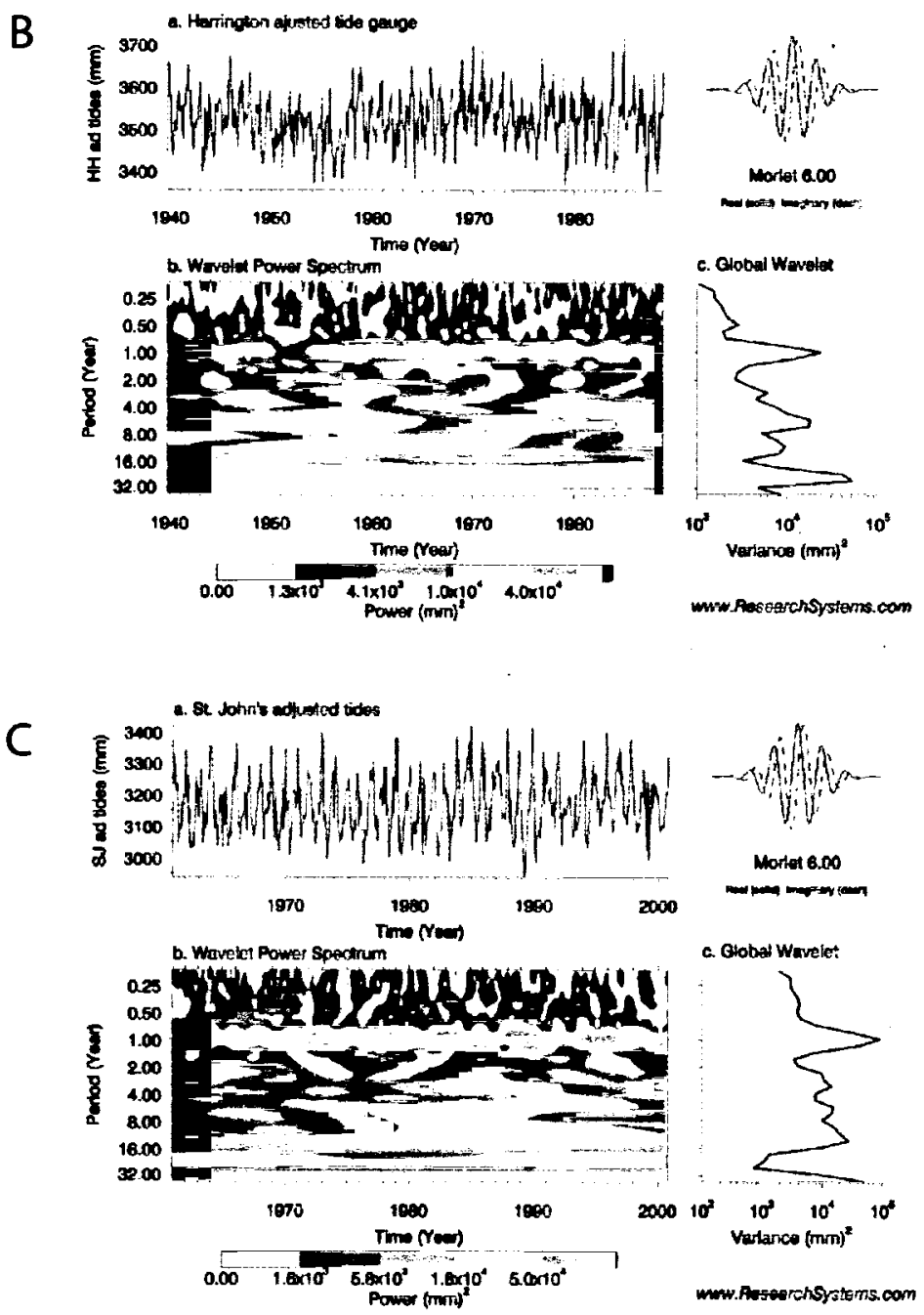

Figure 3.5 Wavelet analysis results of detrended tide gauge records from A) Halifax, NS B) Harrington Harbour, QC, and C) St. John's, NF. 


\section{$\underline{\text { Discussion }}$}

The results of the linear regression analysis show a geographic variation in vertical land movements. Tide gauges in southern locations depict the most rapid local relative sea-level rise, and the rate of local sea-level change decreases to the north. The zero isobase of vertical land movement is located between Lark Harbour, NF and Harrington Harbour, QC. This and the other isobases, as far as they may be delineated by this study, are roughly parallel to the LGM ice margin.

A comparison of contoured vertical land movement based on linear regression results between this study and Emery and Aubrey (1991) shows very different patterns of change (Figure 3.6). In a linear regression of the Port-aux-Basque tide gauge, Emery and Aubrey (1991) included the very oldest data available. Because they analyzed annual water levels, this data amounted to only one point for analysis, and is separated from the remaining data by several decades. The inclusion of this point in the analysis strongly weights the trend of the line, resulting in strongly curved contours of uplift around Newfoundland. The oldest data from Port-aux-Basques were not included in the regression performed for this study. Instead of indicating rising land levels, the regression analysis for this study indicated that the most rapid rate of local relative sealevel rise was at Port-aux-Basques. Contours of vertical land movement, the inverse of local relative sea-level change, from this study cross-cut those defined by Emery and Aubrey (1991), and are less convoluted.

Power analysis of the Harrington Harbour tide gauge record shows peaks at 1year and $\sim 18$-year periodicities that agree with astronomic cycles known to exert a strong influence on tides. The $\sim 18$-year periodicity was not identified in records from Port-aux- 


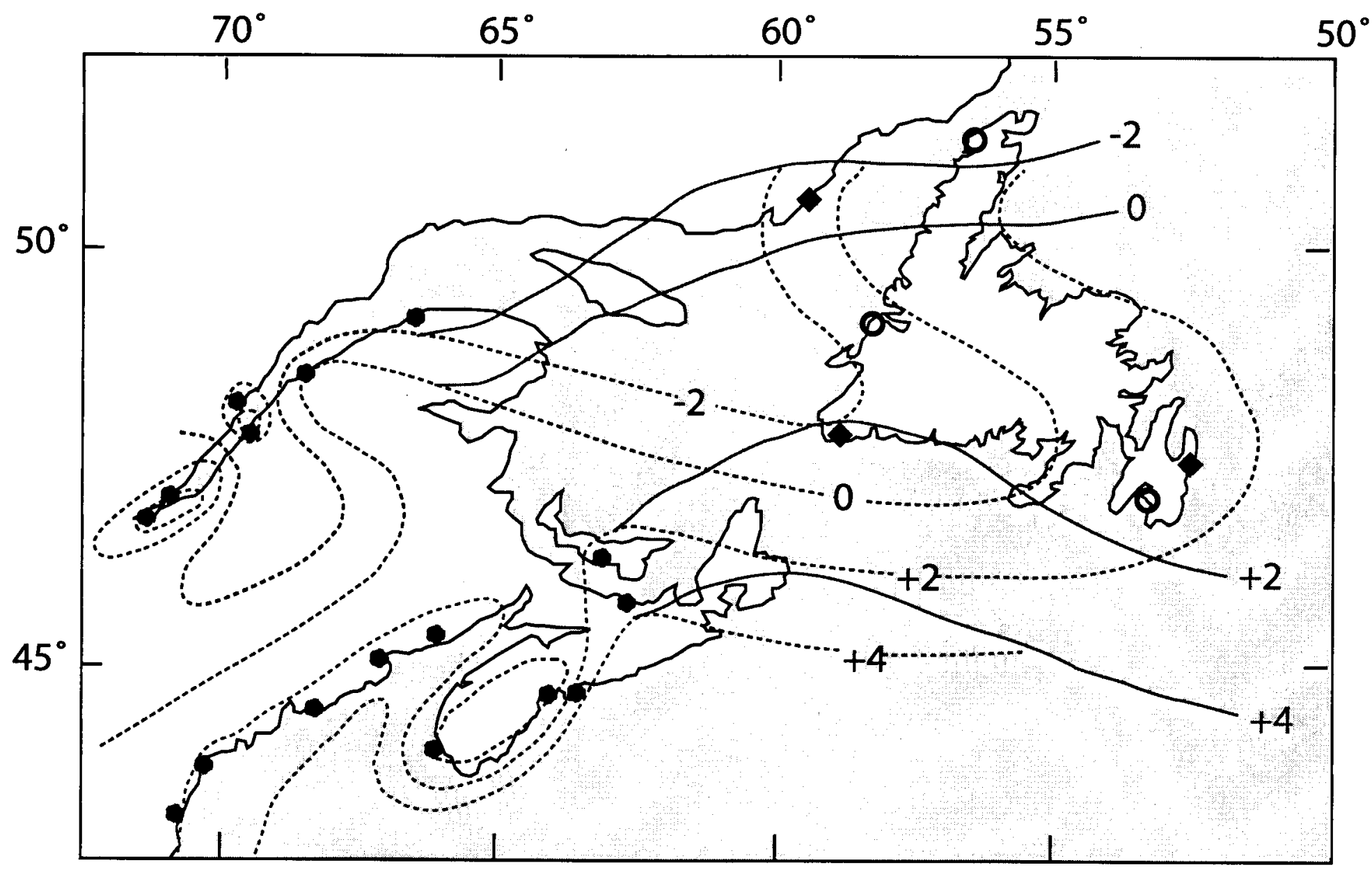

Figure 3.6 Contours of vertical land movement based on linear regression of tide-gauge records. Dashed lines are contours as drawn by Emery and Aubrey (1991) based on tide gauges shown by black symbols. Full lines are contours based on rates determined in this study of only the tide gauges indicated by diamonds. Three additional records (open circles) were used in this study. Contour intervals are $2 \mathrm{~mm} / \mathrm{yr}$. 
Basques or St. John's by El Sabh and Murty (1986), perhaps due to the short duration of the records they analyzed. The 6-year periodicity was previously found in records from Halifax, NS and St. John, NB, but not in Newfoundland records (El-Sabh and Murty, 1986). The 6-year periodicity is not easily explained by astronomic variability. It may correlate with the North Atlantic Oscillation. 


\section{Chapter 4}

\section{MODERN FORAMINIFERAL SURFICIAL ZONATIONS}

\section{Introduction and Previous Research}

Agglutinated salt-marsh foraminifera are ecologically zoned with respect to salinity, which is often a proxy for elevation above mean high water (MHW) (Scott and Medioli, 1978, 1980; Scott et al., 2001). Two primary foraminiferal zones are associated with low marsh and high marsh vegetation, but each are subdivided into two subzones (Scott and Medioli, 1978). Characterization of these zones at a marsh is used to assign a paleo-MHW range to subsurface peat samples; this range is termed the indicative meaning' (van de Plassche, 1988). For sea-level studies, the greatest interest is placed on determination of the leading edge of the salt marsh. The highest foraminiferal zone, 1a, is characterized by a nearly monospecific population of $J$. macrescens and is shown to have a restricted vertical range (Scott and Medioli, 1978, 1980; Gehrels, 1994).

The vertical range of these subzones varies spatially (de Rijk, 1995; Gehrels et al., 1996). It was initally assumed that the primary control on the foraminiferal zonation is frequency of flooding, which controls porewater salinity at a given elevation. Therefore, the foraminifera were used as a proxy indicating elevation above mean high water. However, porewater salinity may vary as a result of groundwater seepage, surface runoff, and rain (de Rijk, 1995; de Rijk and Troelstra, 1997). These other factors may control porewater salinity, altering the foraminifera population (de Rijk and Troelstra, 1997). Depending on the degree of freshwater input from these sources, the foraminifera population is expected to vary between sites, and may not serve as a good proxy for elevation in all cases (de Rijk and Troelstra, 1997). 
Evaluation of the surficial population at each study site is necessary to determine if vertical zonations exist. An additional complication may be the presence of an infaunal population (Goldstein and Harben, 1993; Ozarko et al., 1995; Saffert and Thomas, 1999). Studies at several locations (CT, SC, BC) indicate that a significant population of some foraminifera may be living blow the marsh surface (Saffert and Thomas, 1999). Their abundance in fossil samples would bias the overall assemblage. No subsurface samples were checked for live foraminifera in Newfoundland. Preliminary research at sites on the Maine coast did not detect an infaunal population, and this absence is assumed to extend into the Maritimes until further research is completed (Daly et al, 1999). The fossil record may be biased by differential taphonomic preservation (Goldstein, 1988; de Rijk and Troelstra, 1999), but this is also not well studied in the northeast.

Correlation of the results of studies by various authors is hindered by differing identifications of key foraminifera. The original studies delineating zones 1a, 1b, 2a, and $2 \mathrm{~b}$ identified the dominant component of zone $1 \mathrm{a}$ as Trochammina macrescens (Scott and Medioli, 1978; 1980). At that time, this species was recognized as having two varieties that were end-members of a morphological spectrum (Scott and Medioli, 1980). Subsequently, these two varieties have been re-assigned to different genera, Jadammina macrescens and Balticammina pseudomacrescens (Brönniman et al, 1989; de Rijk, 1995; Gehrels, 1999). This division is not universally accepted, and it is often difficult to distinguish the species at the juvenile stage (Tim Patterson, pers. comm., 2001). 


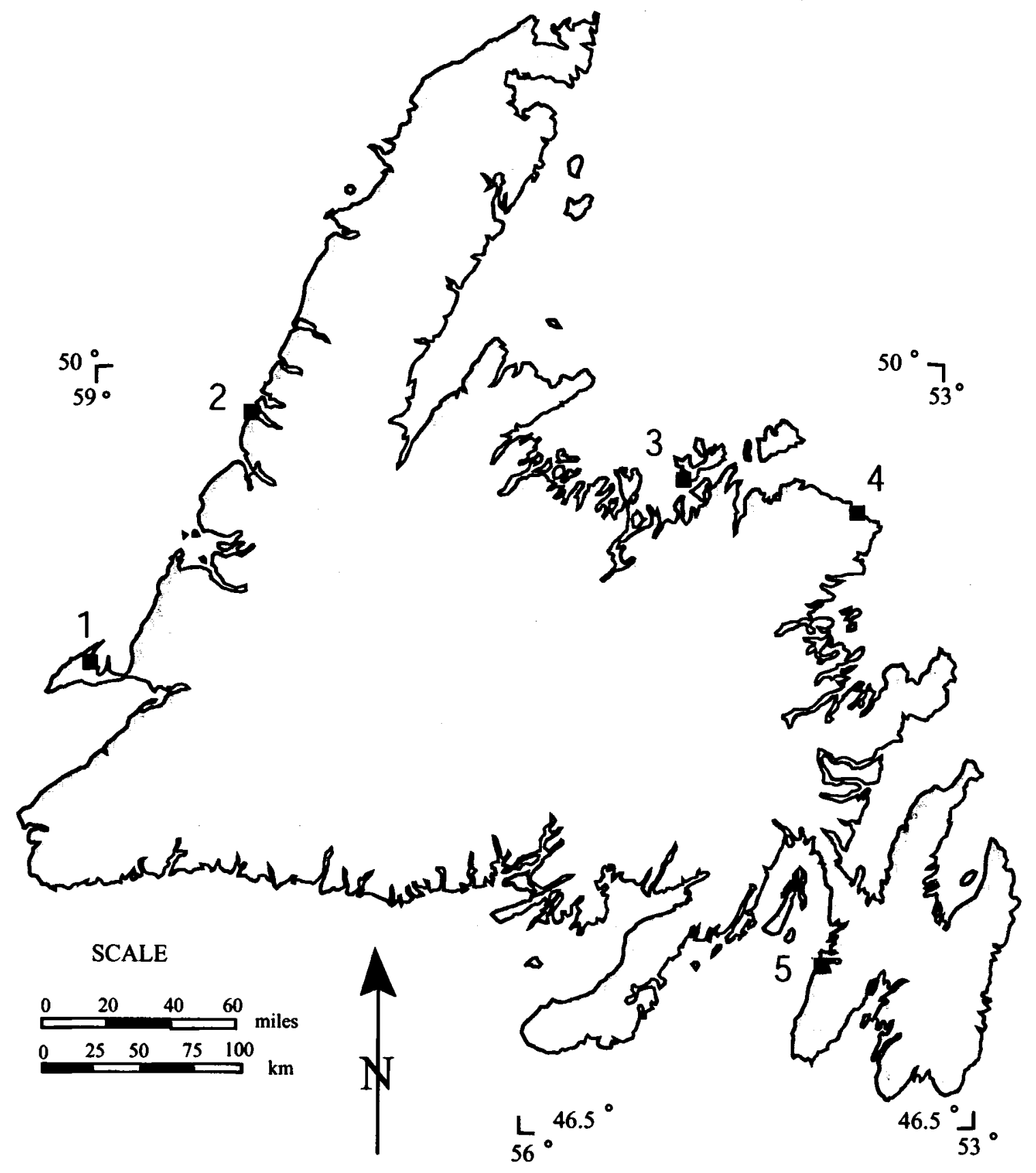

Figure 4.1 Location map of surficial foraminifera sampling sites. Samples from sites 1, 2, 3, and 5 had foraminifera. Samples from site 4 (Deadman's Bay) were barren. 


\section{$\underline{\text { Results }}$}

\section{Introduction}

Surficial samples were collected at five sites around Newfoundland (Fig 4.1)

(Table 4.1). All of the sample sites were leveled to the local MHW datum. Low elevation samples from each site were screened first. At Deadman's Bay barrier, these samples were barren with respect to foraminifera, and no further samples were examined. Results reported here are from samples collected at Hynes Brook, St. Paul's Inlet, New World Island, and Placentia. At these sites, samples were examined to the top of the transect or until several barren samples from similar elevation were found. Of the 60 samples collected, 37 samples had some foraminifera (Figure 4.2).

\begin{tabular}{lll}
\hline Location & Transect & Number of samples \\
\hline Hynes Brook & 1 & 9 \\
& 2 & 6 \\
St. Paul's Inlet & 1 & 6 \\
& 2 & 9 \\
Village Cove & 1 & 8 \\
Deadman's Bay & 1 & 8 \\
& 2 & 6 \\
Placentia & 1 & 8 \\
TOTAL & & 60 \\
\hline
\end{tabular}

\section{Population and Diversity}

A total of nine species were identified in this study (Table 4.2). A formal description of these species is included in Appendix I. At most locations, only six or seven of these species are present. The calcareous species (E. advena) is found rarely and is not considered an important indicator species. In this study, J. macrescens and $B$. pseudomacrescens are differentiated following Gehrels et al. (1999). In most samples including both species, adults are easily identified. Inspection of the ventral side of both 


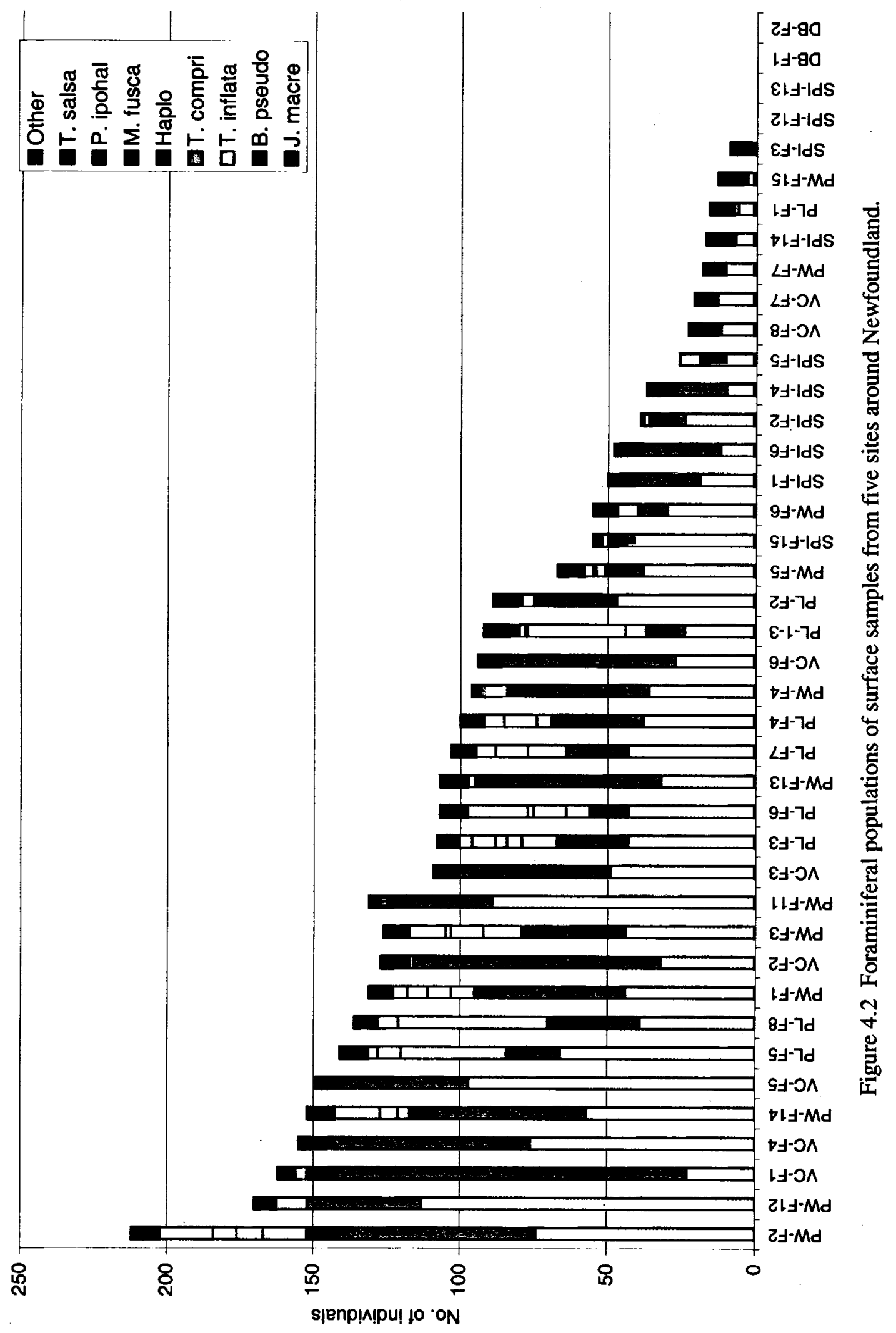


species shows that the umbilicus is much more open on the B. pseudomacrescens (Figure 4.3). Some samples had more juveniles; the differentiation between species at this stage is more problematic (Tim Patterson, pers. comm., 2001).

Table 4.2 Agglutinated and calcareous foraminifera identified in this study.

\begin{tabular}{ll}
\hline Agglutinated & Calcareous \\
\hline Balticammina pseudomacrescens & Eggerella advena \\
Haplophragmoides sp. & \\
Jadammina macrescens & \\
Miliammina fusca & \\
Polysaccima ipohalina & \\
Tiphotrocha comprimata & \\
Trochammina inflata & \\
Trochamminita salsa & \\
\hline
\end{tabular}

Foraminiferal abundances are correlated to elevation above mean high water. In general, abundance decreased with elevation (Figures $4.4 \mathrm{a}-\mathrm{d}$ ), but the correlation is not statistically significant. $J$. macrescens and B. pseudomacrescens dominated the assemblages at each sampled site. $M$. fusca, $T$. inflata, and $T$. comprimata were the most common minor constituents. T. salsa is only associated with surficial samples from Placentia, but a careful re-examination of samples from other sites may lead to a broader geographic distribution.

\section{Cluster Analysis}

Twenty-nine samples had enough foraminifera to include in a cluster analysis. The SYSTAT 'complete' cluster analysis tool yielded three major clusters (Figure 4.5). Based on this grouping, the compositions of the samples in each cluster were averaged to determine a general cluster composition (Figure 4.6). Cluster I is characterized by 

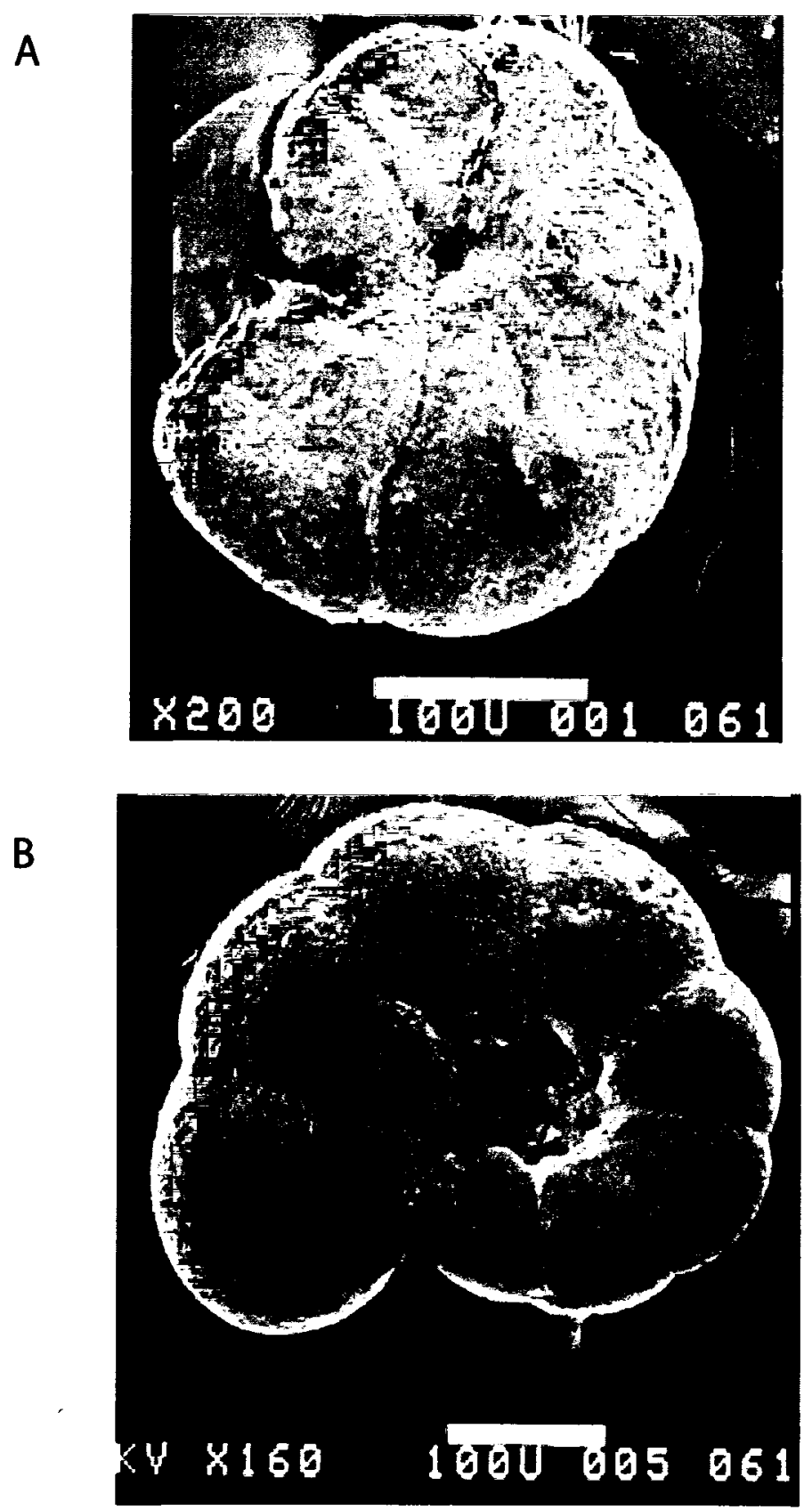

Figure 4.3 SEM images of the ventral side of A) J. macrescens and

B) B. pseudomacrescens. Note the open umbilicus of $B$. pseudomacrescens. 

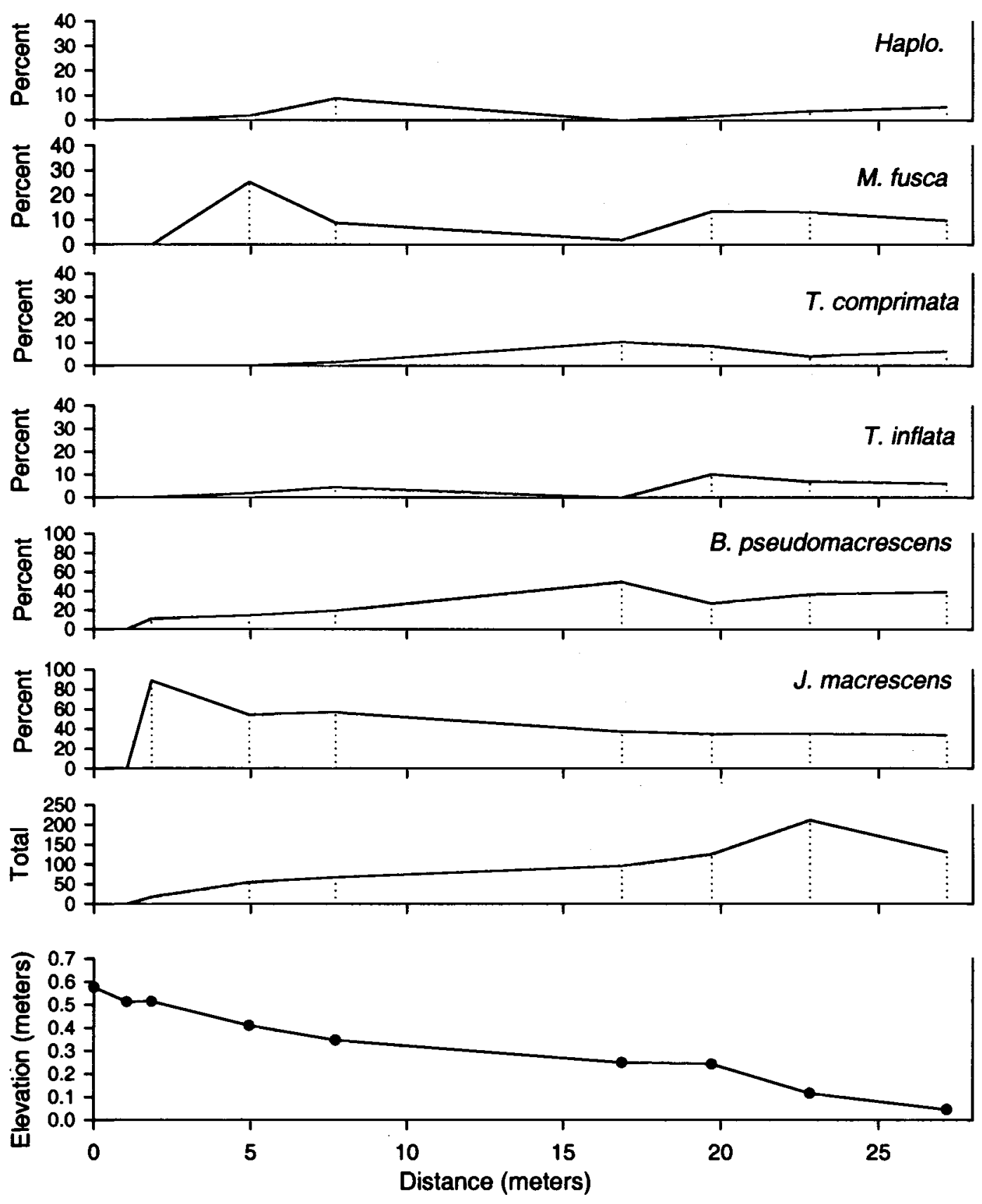

Figure 4.4a Surface sample transect 1 at Hynes Brook. 

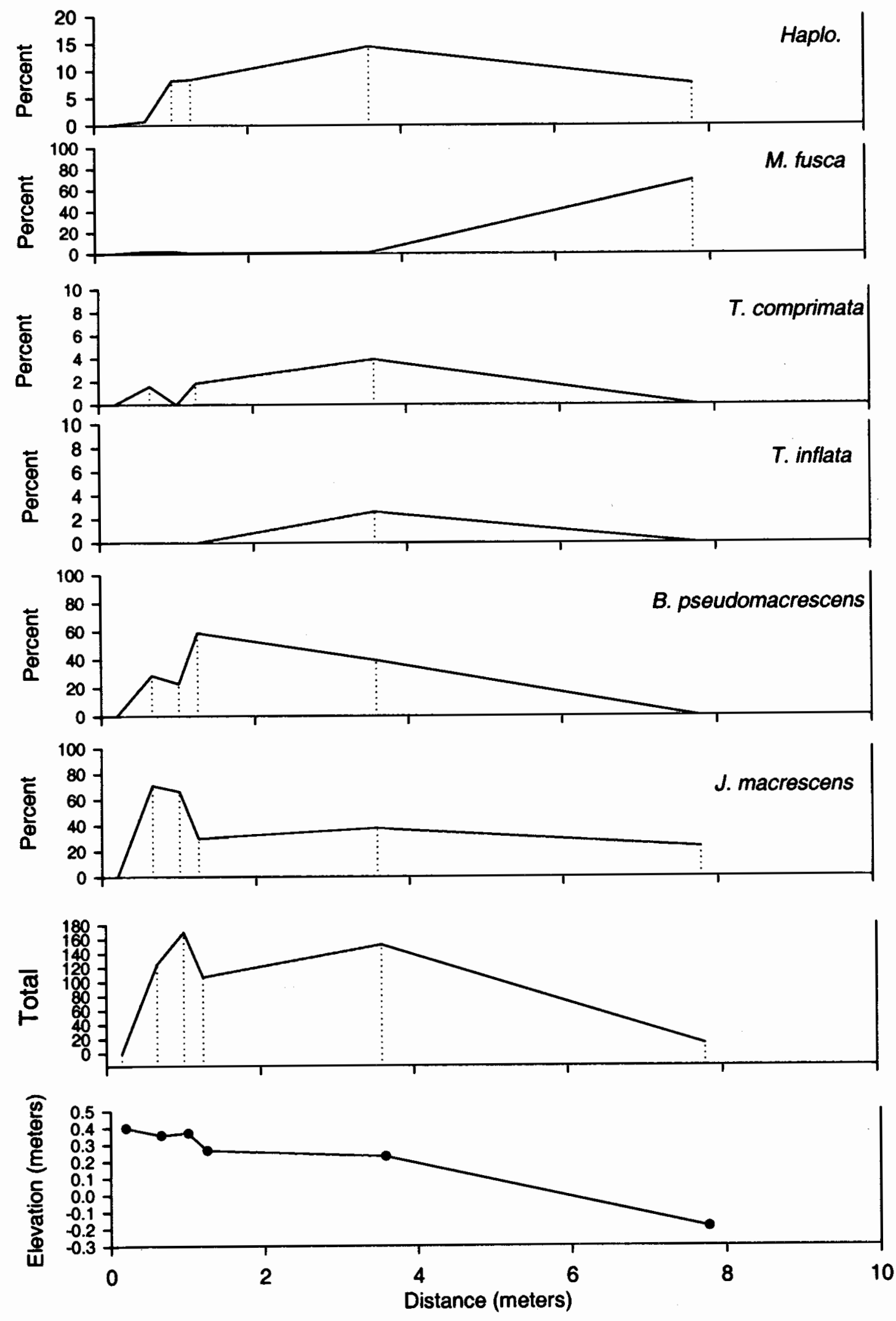

Figure 4.4b Surface sample transect 2 at Hynes Brook. 

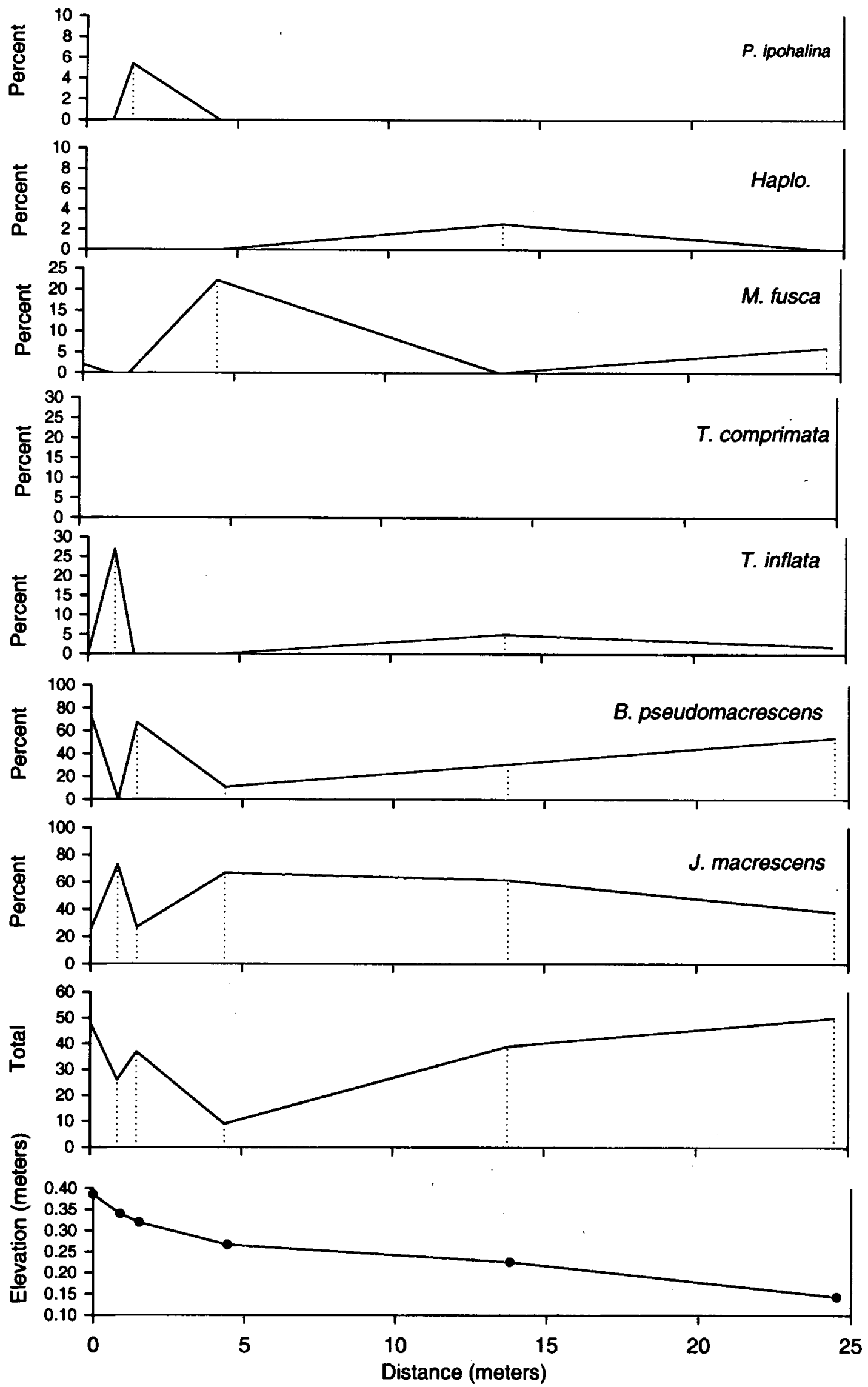

Figure 4.4c Surface sample transect 1 at St. Paul's Inlet. 


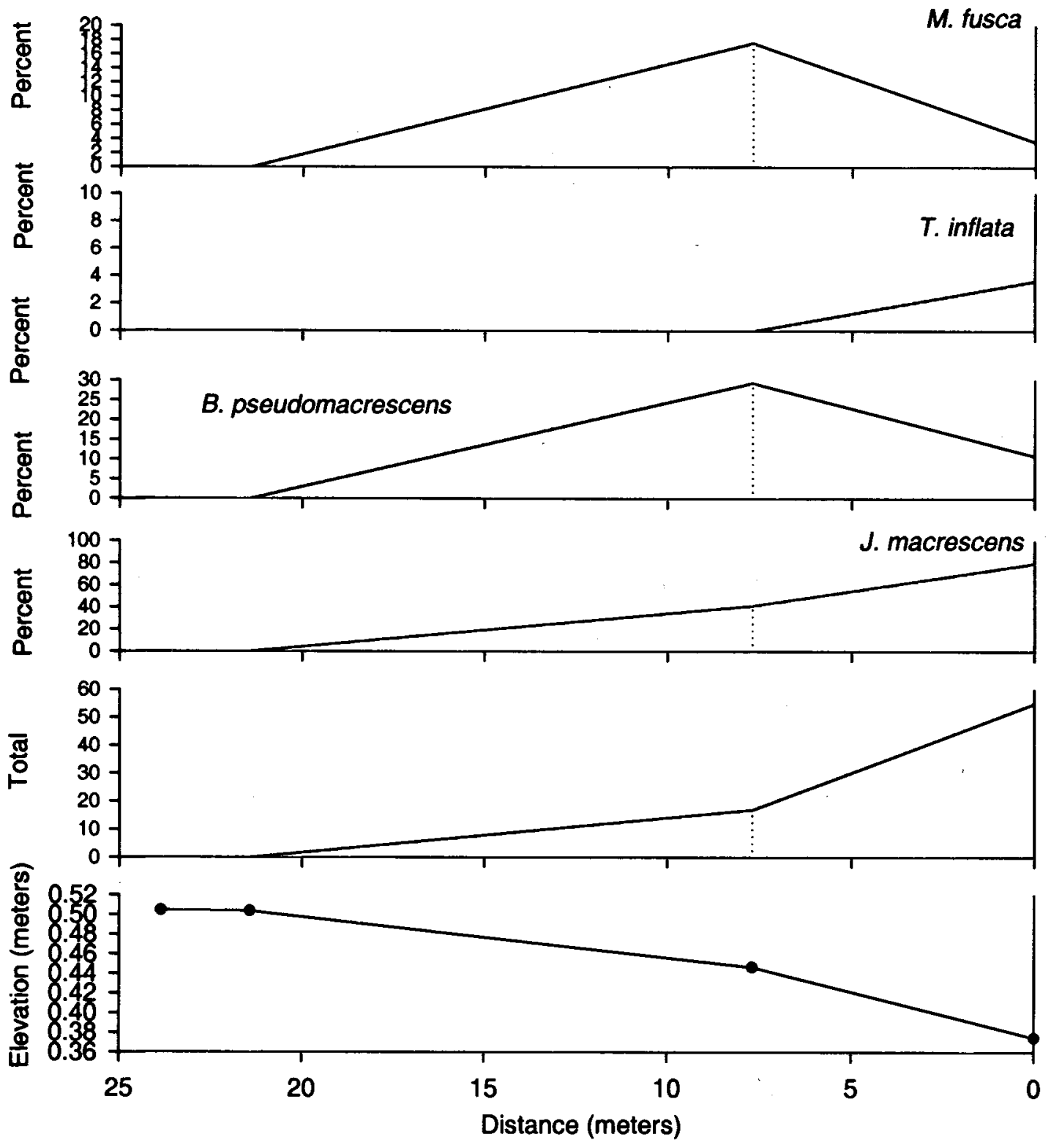

Figure 4.4d Surface sample transect 2 at St. Paul's Inlet. 

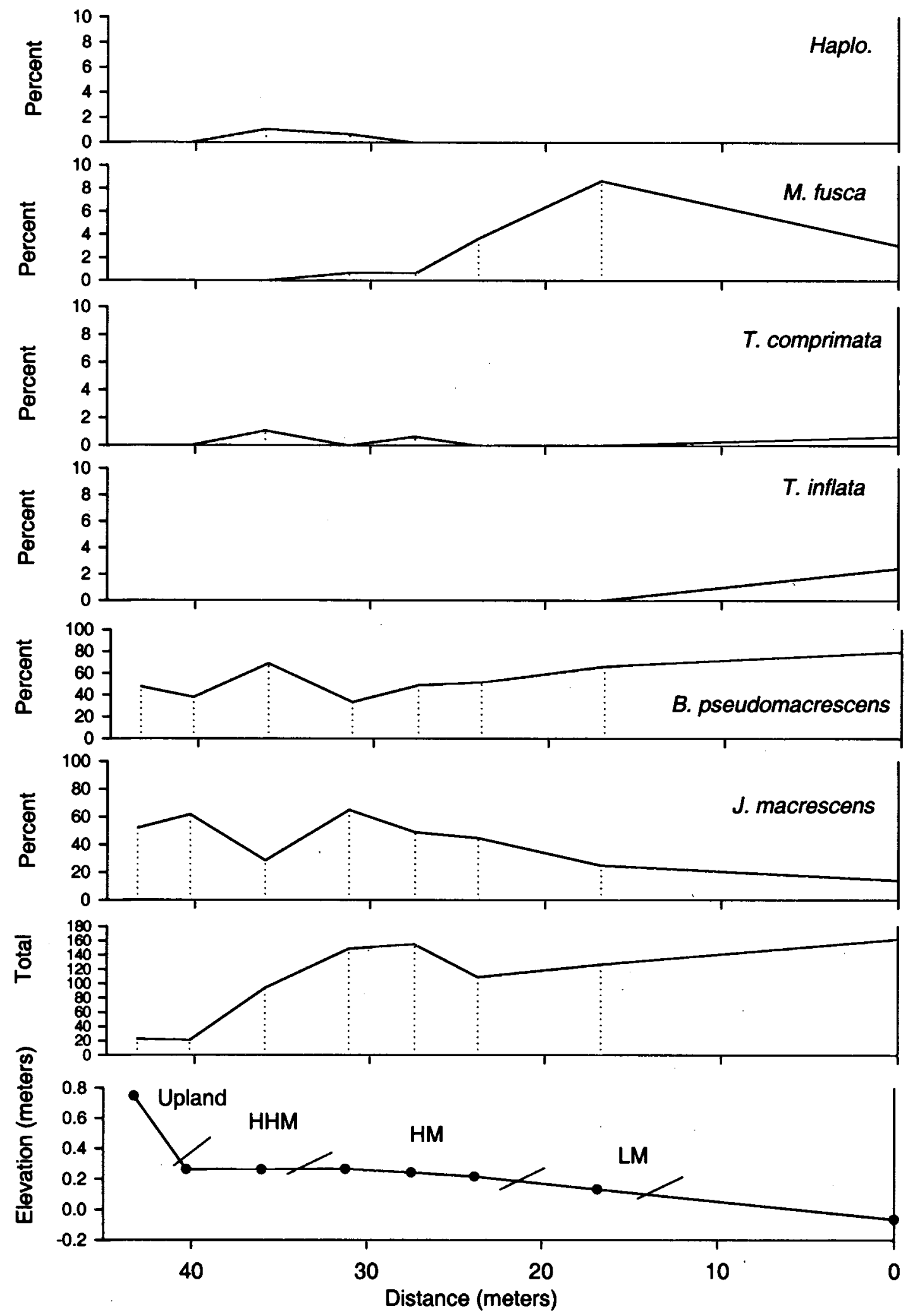

Figure 4.4e Surface sample at Village Cove. 

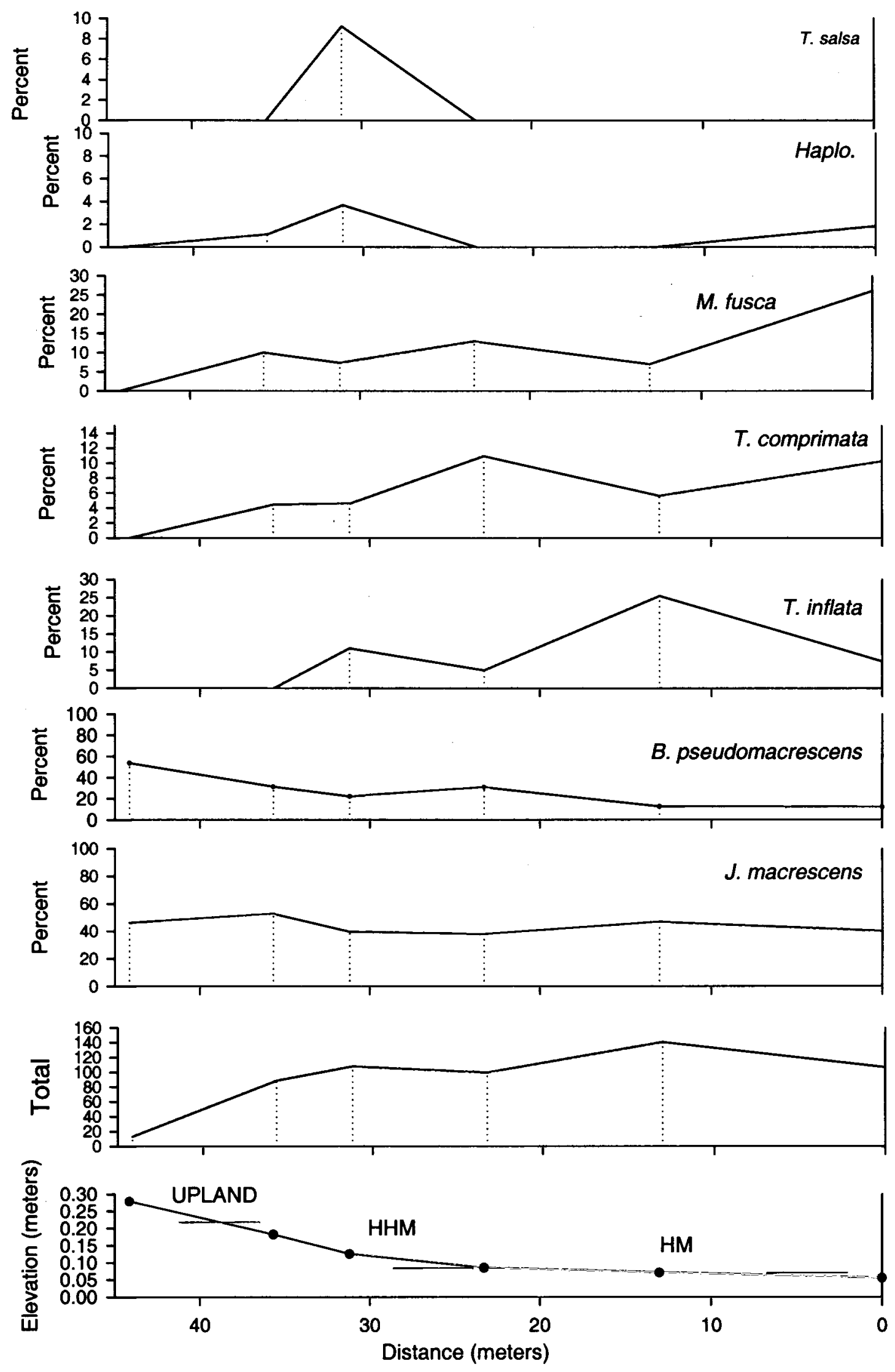

Figure 4.4f Surface sample at Placentia. 


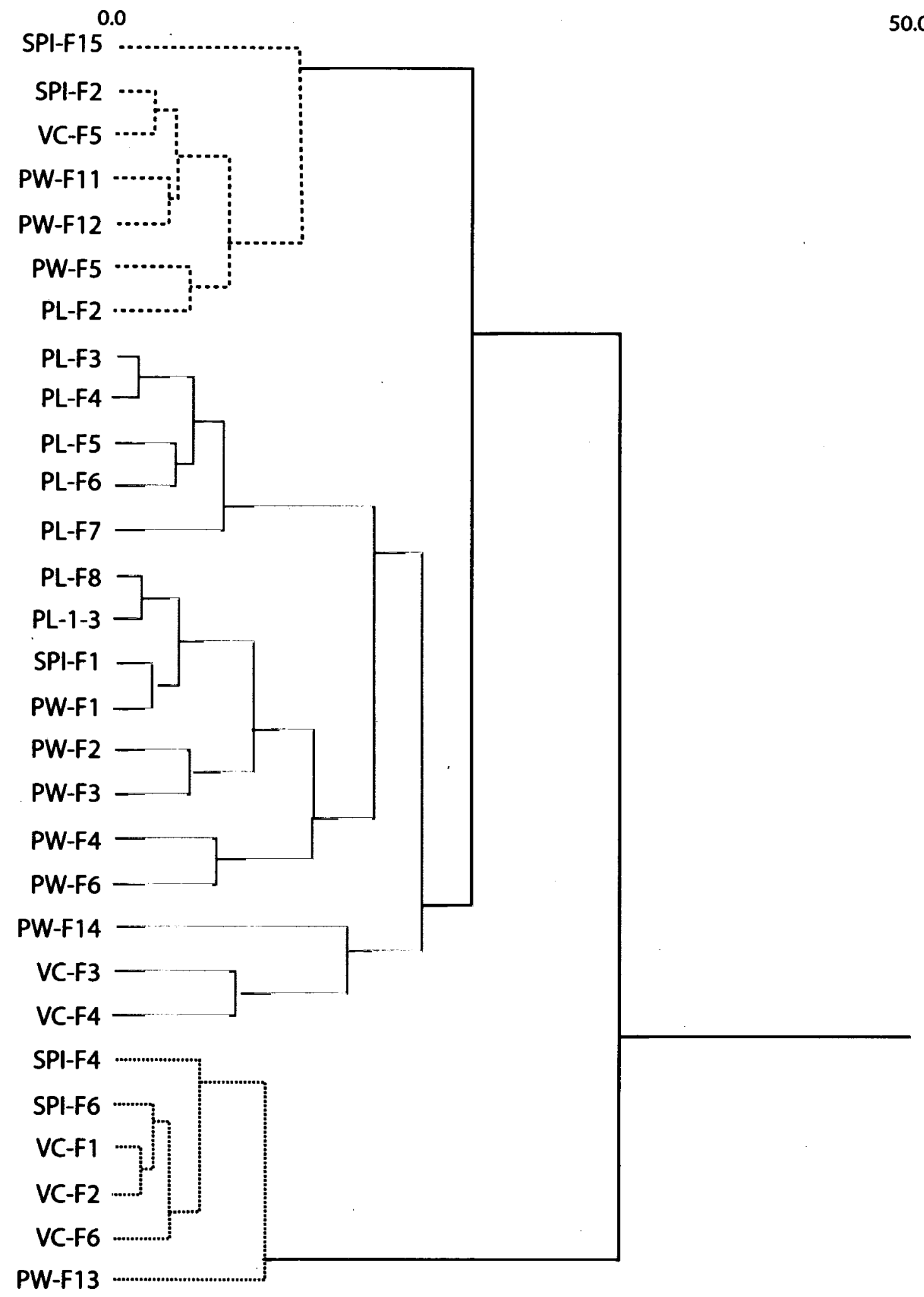

Figure 4.5 Results of complete cluster analysis of 29 surficial samples. 


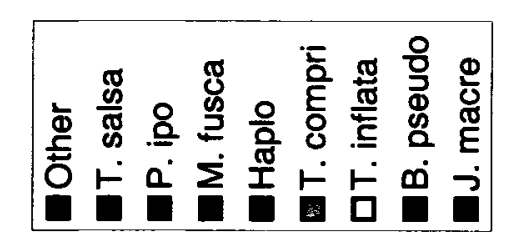

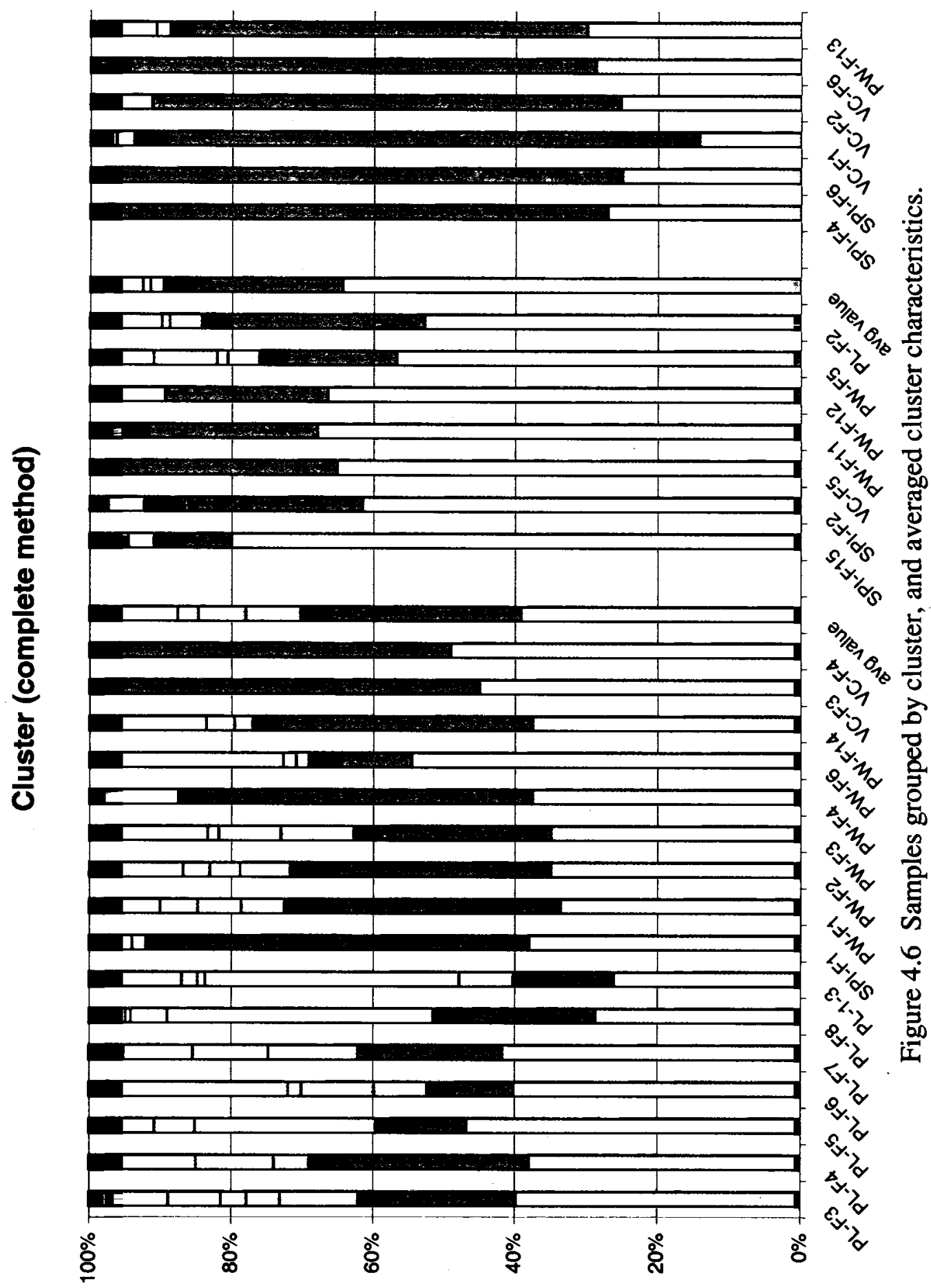


abundant $J$. macrescens and B. pseudomacrescens, and a diverse assemblage of minor constituents. Cluster II is characterized by abundant $J$. macrescens, minor $B$.

pseudomacrescens, and less diverse minor constituents. Cluster III is characterized by abundant $B$. pseudomacrescens, less $J$. macrescens, and a few minor constituents. Other cluster methods produced similar results, with a few additional clusters of only one or two samples.

\section{Site Zonations}

Based on the results of the cluster analysis, surficial samples at each site can be assigned to a cluster, and foraminiferal zones can be determined. The relationship of these zones to previously published foraminiferal zones (Scott and Medioli, 1979, 1980; Gehrels et al., 1994) is discussed following a description of the zonation at each location.

Two foraminiferal zones are defined at Hynes Brook (Figure 4.7). The lowest zone, associated with cluster 1 , extends from MHW to $0.3 \mathrm{~m}$ and is identified as the high marsh (HM). The second zone, associated with cluster 2 , extends from $0.3 \mathrm{~m}$ to $0.58 \mathrm{~m}$, the lowest occurrence of Iris versicolor and the approximate MHHW elevation. This zone is designated the higher high marsh (HHM). Foraminiferal abundance in the upper zone decreased with elevation; sample F7 had a count of 144/cc whereas sample F8 had an abundance of $1008 / \mathrm{cc}$. The F7 assemblage is consistent with cluster 2 , but the sample size was considered too small to include in the cluster analysis.

Three foraminiferal zones are defined for St. Paul's Inlet (Figure 4.7). Samples were collected along two transects. The low marsh zone, corresponding to cluster 1 at this site, extends from MHW to $0.15 \mathrm{~m}$. The HM zone, corresponding to cluster 2, 


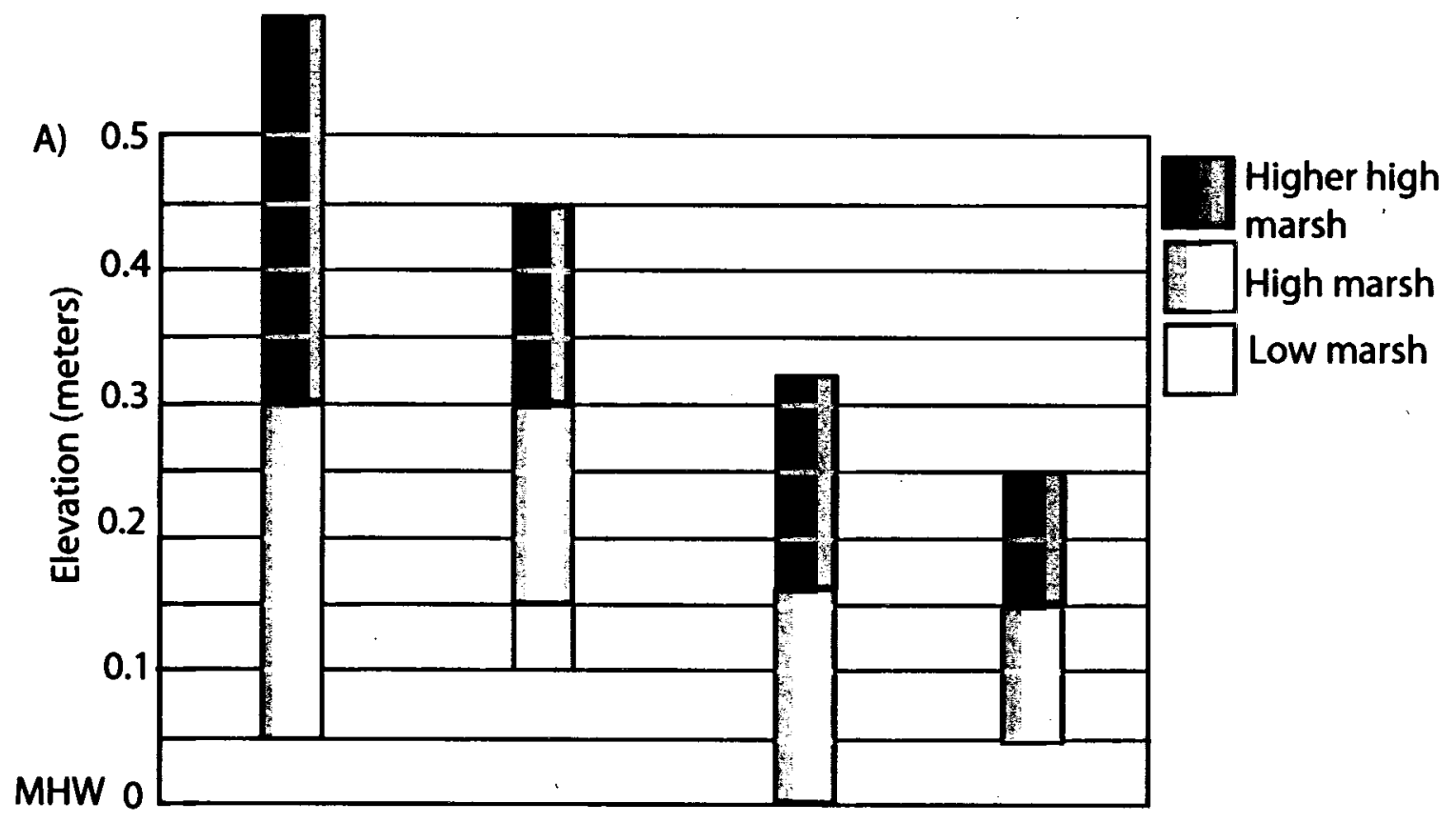

Hynes Brook St. Paul's Inlet Village Cove, NWI Placentia

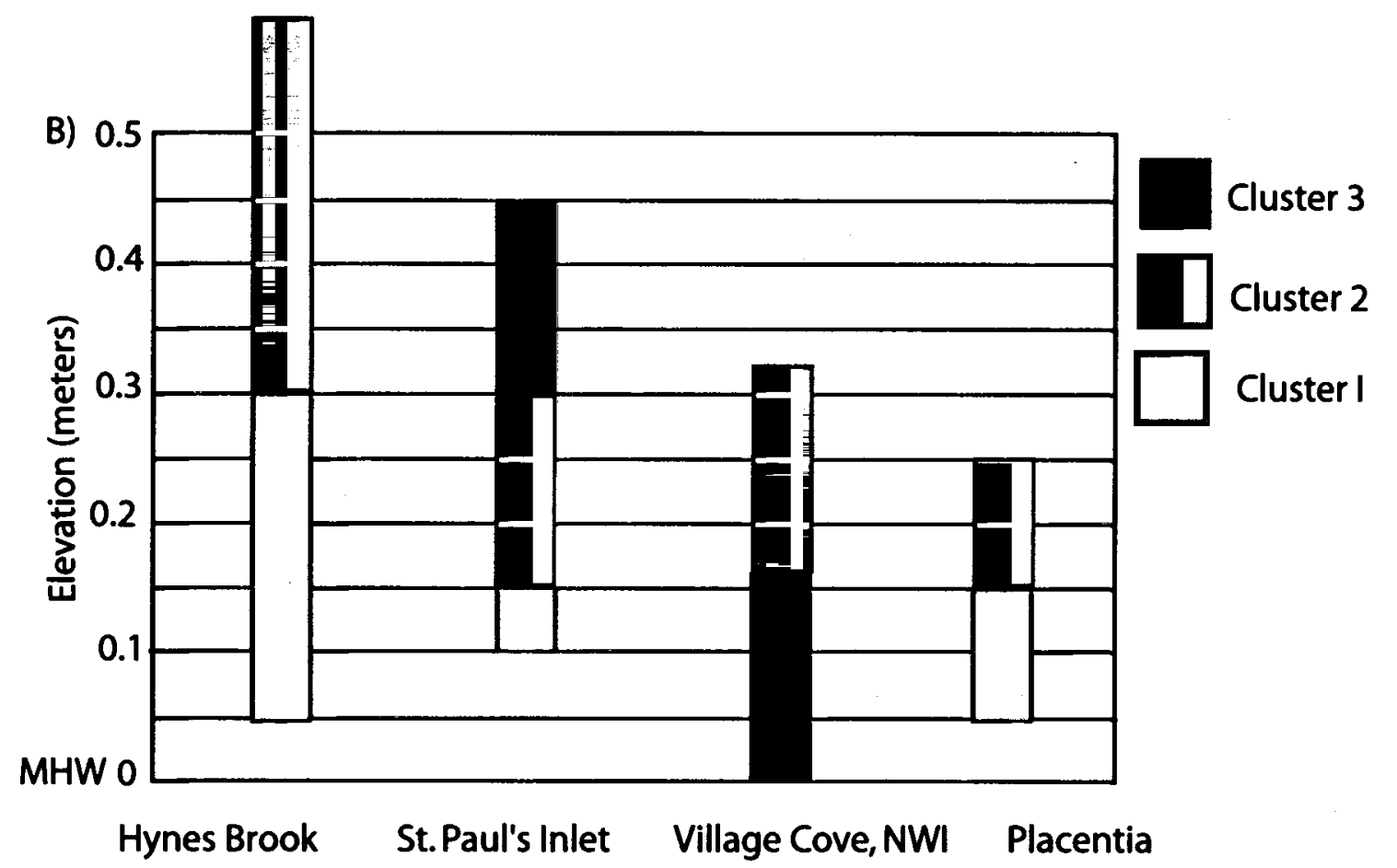

Figure 4.7 A) Marsh zonations at four field sites, based on foraminiferal and plant assemblages. B) Cluster associations with each zone. 
extends from $0.15-0.3 \mathrm{~m}$. The HHM zone extends from $0.3-0.45 \mathrm{~m}$, and corresponds to cluster 3. Samples above this elevation were barren, and the surface becomes a bog or upland above this elevation.

Two foraminiferal zones are defined for Village Cove, New World Island (Figure 4.7). The HM, corresponding to cluster 3, extends from $\mathrm{MHW}$ to $0.17 \mathrm{~m}$. The HHM extends from $0.17-0.32 \mathrm{~m}$, and corresponds to cluster 1 . This zonation is applied to core samples from Deadman's Bay barrier.

Three foraminiferal zones are defined for Placentia (Figure 4.7). HM, associated with cluster 1 , extends from MHW to $0.15 \mathrm{~m}$. HHM, associated with cluster 2, extends from $0.15-0.25 \mathrm{~m}$. Above $0.25 \mathrm{~m}$, Scirpus is present and indicates a transition to freshwater conditions.

\section{Discussion}

Low marsh, high marsh, and higher high marsh zones are defined for sites around Newfoundland, but there is considerable variability among the sites. This may be a function of variations in tide range or, more likely, local hydrologic characteristics. At locations where more than surface sample transect was sampled, there is agreement between the two transects with respect to the zonation. The elevation of the zones may vary slightly between the two transects; this variation also indicates that local run-off or groundwater seepage may control the foraminiferal zonation. In addition, the zonations described for these sites vary from descriptions of other LM, HM, and HHM zones. In general, floral and foraminiferal species associated with low marsh environments at other 
locations (e.g., Ammotium salsum) are not present at any location. Greater rainfall, and therefore freshwater input to the marsh, may be repsonsible.

A more complete ecological characterization of the flora and foraminifera at each site would be required to best assess the potential sea level record. The results of these preliminary surveys indicate that each zonation may be an appropriate tool for reconstructing local MHW change but should not be broadly applied to distant locations. More rigorous statistical analysis and characterization of the zones requires a greater number of samples and auxiliary information, such as temporal and spatial $\mathrm{pH}$ variability at the field sites. If the foraminiferal populations are significantly influenced by rainfall or seasonality, it is possible that down-core variations in the foraminiferal assemblage are a response to these factors. 


\section{Chapter 5}

\section{HYNES BROOK, PORT-AU-PORT PENINSULA}

\section{Introduction and Geologic Setting}

Paleozoic carbonate platform sediments provide the framework for the Port-auPort peninsula. Tilted beds on the north side of the peninsula define two large, shallow embayments. Numerous swash-aligned barrier-spits line the shore of West Bay. They are supplied by the updrift erosion of highstand marine terraces and glacial material.

Hynes Brook is the local name for a small stream that enters West Bay at the border between Picadilly Head and West Bay Centre (Figure 5.1). At the stream outlet, a small sand and gravel barrier diverts the outlet slightly to the east. Tidal ranges predicted for the harbor of Port-au-Port, $30 \mathrm{~km}$ to the east, are a mean tidal range of $1.06 \mathrm{~m}$ and a spring tidal range of $1.30 \mathrm{~m}$ (Canadian Hydrographic Service, 1999). These ranges are probably significantly truncated in the backbarrier environment (Table 5.1). Between the barrier (to the north) and Rt. 463 (to the south) the stream is flanked by a fluvial-fringing marsh. Relatively steep valley walls restrict the marsh and confine the meandering stream. The marsh is well zoned with respect to vegetation, and is dominated by high marsh and higher high marsh flora (Figure 5.2). Several small salt pannes are found on the western side of the marsh. Spartina alterniflora characterizes the low marsh. Juncus gerardii, Potentilla species, Scirpus species, and Solidago sempervirens characterize the higher high marsh. Iris versicolor marks the upper limit of marine influence at the margin of the marsh. 

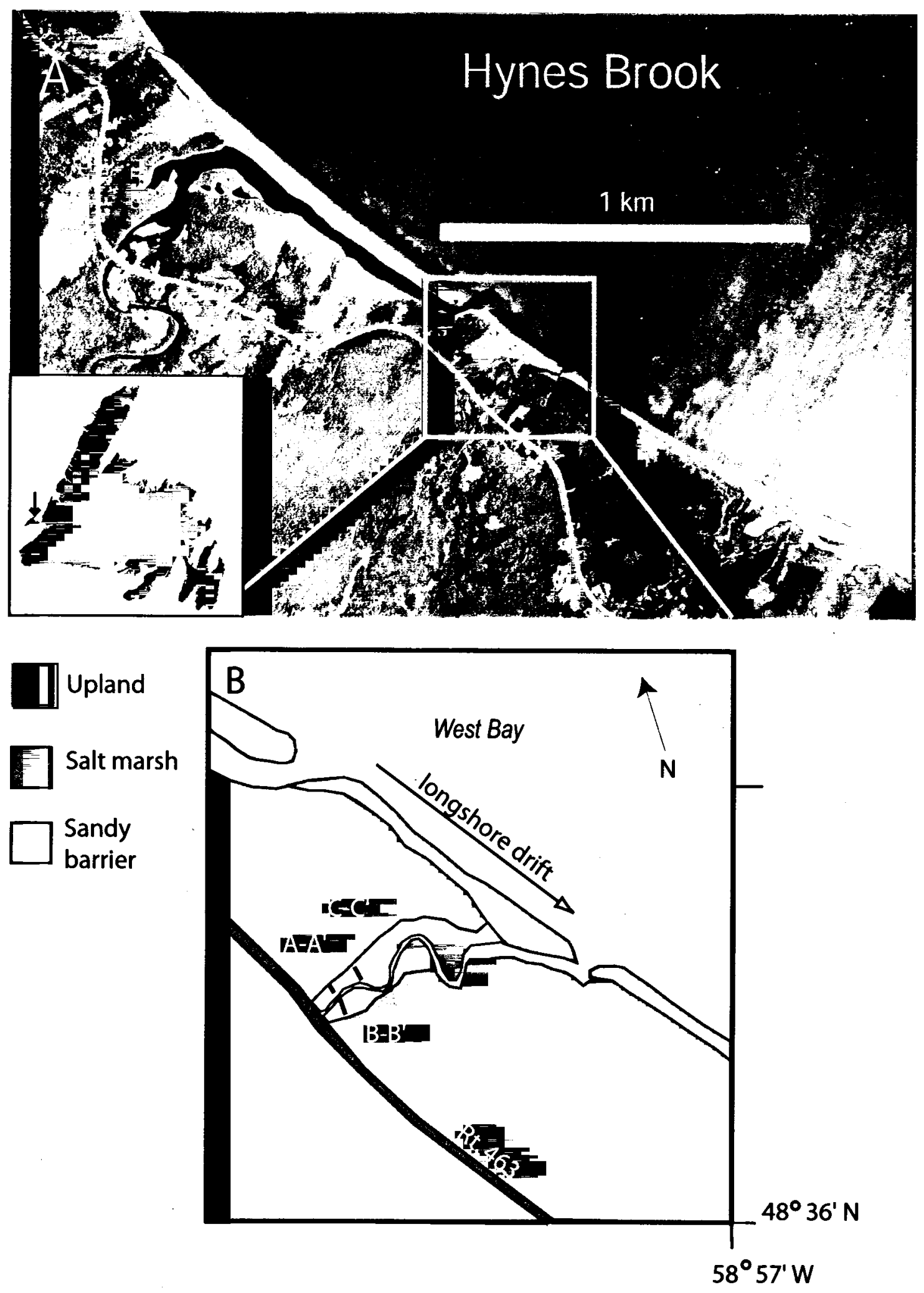

Figure 5.1 A) Location map for site at Hynes Brook. B) Simplified geomorphic map of Hynes Brook site. 

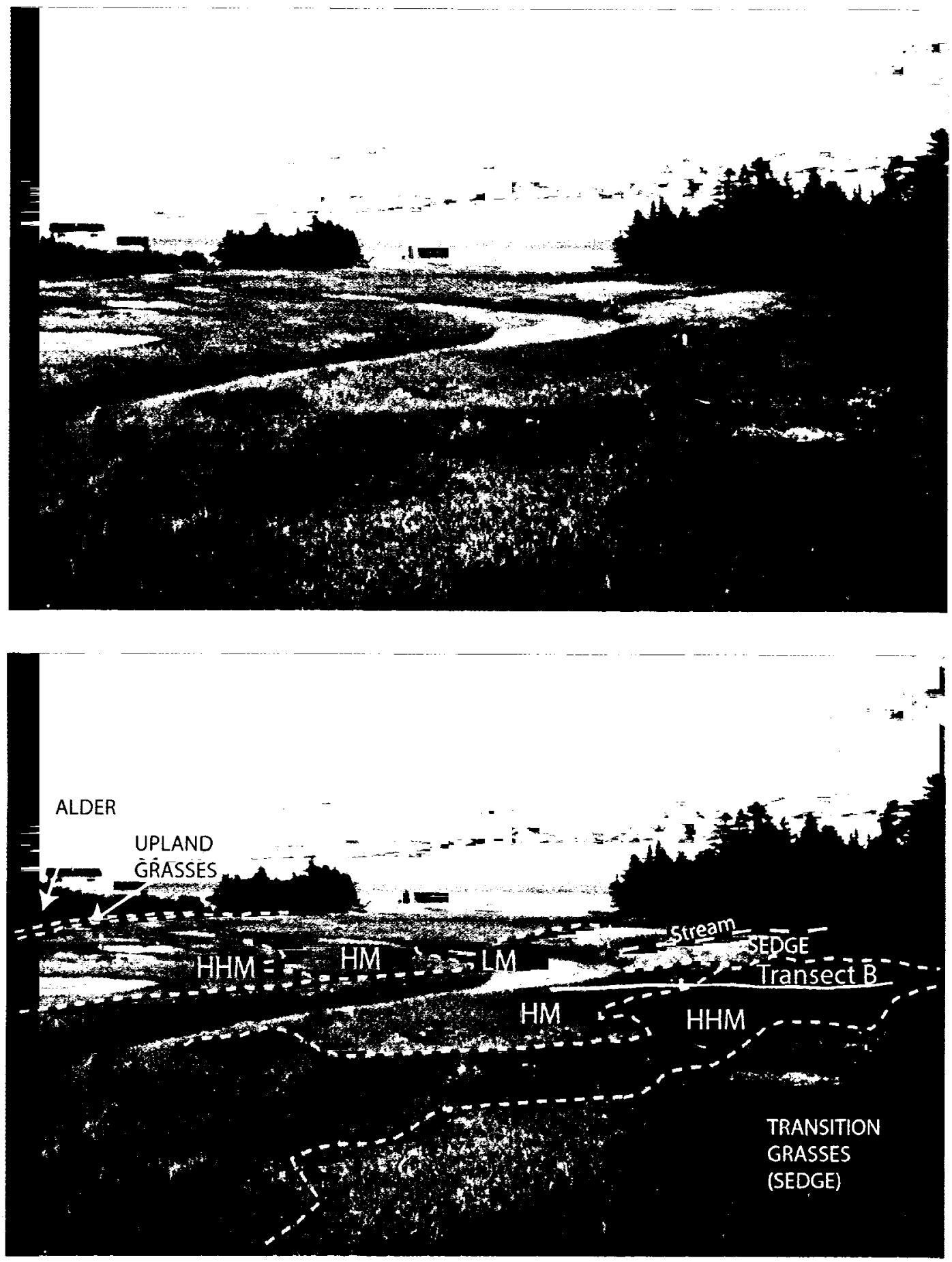

Figure 5.2 Oblique view of Hynes Brook field area. Interpretation below indicates major floral zones and the location of one transect (B). 
Table 5.1 Tidal range data for Port-au-Port and Hynes Brook (Canadian Hydrographic Service, 1999).

\begin{tabular}{ll}
\hline Mean tidal range & $1.06 \mathrm{~m}$ \\
\hline Spring tidal range & $1.3 \mathrm{~m}$ \\
Predicted tidal range (7-2-99) & $0.80 \mathrm{~m}$ \\
Measured tidal range (7-2-99) & $0.49 \mathrm{~m}$ \\
\hline
\end{tabular}

\section{Previous Work}

This location falls within the "Type B" sea-level area defined by Quinlan and Beaumont (1981, 1982). Regional sea-level change has been studied for nearly three decades, but significant uncertainties remain. Recent re-mapping of late- and post-glacial deposits indicates that defining the post-glacial highstand is more complicated than previously known (Bell et al., 2001). Features interpreted as post-glacial deltas in this area were re-mapped as submarine fans, limiting their utility for constraining sea level. Bell et al. (2001) suggest that only one reliable high-stand indicator may be identified at $+35.4 \mathrm{~m}$, and dated to $16,100 \mathrm{cal}$ yr BP. Basal freshwater peat dates at present sea level indicate sea level passing below present by $\sim 10,500 \mathrm{cal}$ yr BP (Table X.2). Geophysical profiling of St. George's Bay, south of the Port-au-Port peninsula, indicates a sea-level minimum of at least $-20 \mathrm{~m}$ (Shaw and Forbes, 1995). The age of the lowstand is unknown, but is thought to be between 9,000 and $10,000{ }^{14} \mathrm{C}$ yr BP (Shaw and Forbes, 1995).

Previous work at Hynes Brook included foraminiferal analysis of two cores in the backbarrier area, slightly north of the transects investigated in this study (Brookes et al., 1984). Calibrated basal peat dates of $\sim 2500$ yr BP and $\sim 3000$ yr BP indicate sea-level rise of $\sim 1 \mathrm{~m} / \mathrm{kyr}$ through the late Holocene at this location (see Table 2.2). More recent work 
at Big Marsh, a marsh immediately west of Hynes Brook, confirms this rate of long-term sea-level rise (Wright and van de Plassche, 2001).

\section{Results}

\section{Salt-marsh Stratigraphy}

Stratigraphic units are low marsh, high marsh, higher high marsh, and transitional peat, compact mud, and sandy gravelly mud. Cores collected along four transects reveal the diverse vertical and lateral distribution of these units. Foraminiferal analyses of surficial samples indicate that two zones may be defined. The surficial foraminiferal zonation at this location is discussed in detail in Chapter 4. This foraminiferal zonation is related to floral changes, and both floral and microfaunal associations were used to interpret peat units from core samples.

Table 5.2 Faunal and floral zones for Hynes Brook, Newfoundland.

\begin{tabular}{|c|c|c|c|c|}
\hline & $\begin{array}{l}\text { Environmental } \\
\text { interpretation }\end{array}$ & $\begin{array}{l}\text { Elevation } \\
\text { above MHW }\end{array}$ & Foraminifera & Flora \\
\hline & Transition & 0.58 & Barren & $\begin{array}{l}\text { Iris versicolor } \\
\text { (MHHW marker) }\end{array}$ \\
\hline $\begin{array}{l}\text { Zone } \\
\text { 1a }\end{array}$ & $\begin{array}{l}\text { Higher high } \\
\text { marsh }\end{array}$ & $0.33-0.58$ & $\begin{array}{l}J . \text { macrescens, } B . \\
\text { pseudomacrescens, } M . \\
\text { fusca }\end{array}$ & $\begin{array}{l}\text { Juncus gerardii, } \\
\text { Potentilla sp., } \\
\text { Solidago sempervirens }\end{array}$ \\
\hline $\begin{array}{l}\text { Zone } \\
1 \mathrm{~b}\end{array}$ & High marsh & $0.08-0.33$ & $\begin{array}{l}B \text {. pseudomacrescens, } J \text {. } \\
\text { macrescens, } M \text {. fusca, } T \text {. } \\
\text { comprimata }\end{array}$ & Spartina alterniflora, \\
\hline
\end{tabular}

Cores were collected along three transects at this field site. Local datum was estimated MHW, based on on-site measurements and tidal predictions for the area. Transects A and B extend away from each other on either side of Hynes Brook. Cores indicate a peat unit thickest on the west side of the transect, adjacent to the present cut bank (Figure 5.3). The peat on the east side of the transect thins away from the stream 


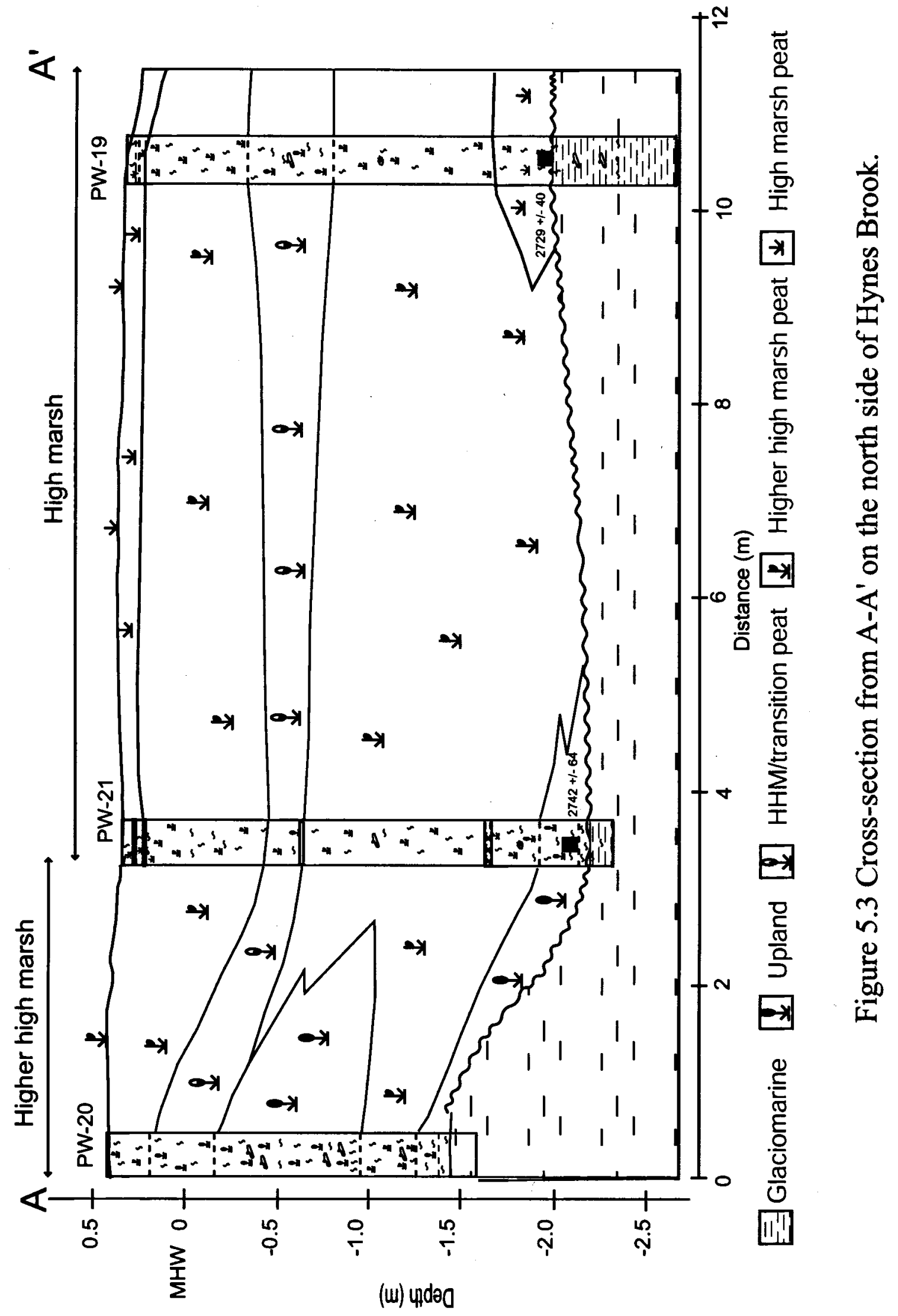


(Figure 5.4). Basal highest high marsh (HHM) or fresh upland peat unconformably overlies a compact mud or muddy sandy gravel. On the eastern side of the transect, the HHM peat grades to a transitional peat that is less than $0.5 \mathrm{~m}$ thick at approximately -1 m. The transition peat grades conformably back to a HHM peat that exists across most of the present marsh surface. On the eastern bank, the peat is less thick, and in some places the transition peat correlative to the middle unit on the opposite bank directly overlies the compact mud. This unit pinches out at less than $-1 \mathrm{~m}$. The transition peat is characterized by very low foraminiferal abundances.

\section{Radiocarbon Dates}

Four samples from this location were submitted for $\mathrm{AMS}{ }^{14} \mathrm{C}$ dating at the University of Arizona facility. All submissions were detrital grass fragments found on horizontal bedding planes near the base of the cores. Two of these samples, from cores PW-23 and PW-24 were too small to run. The data from the two dated samples are included in Table 5.3. Additional samples were not submitted for this project because no other large detrital pieces were recovered from the cores. Bulk samples from crucial elevations will be submitted in the future to provide more definition for the sea-level history at Hynes Brook.

Dates used in the sea-level reconstruction for this area were calibrated using the on-line version of CALIB 4.3 at the University of Washington (http://calib.org/calib/). Published dates were calibrated based on information provided in the publications, except for data from Wright and van de Plassche (2001) that were already calibrated. 
Table 5.3 Radiocarbon data for southwestern Newfoundland from this and published studies.

\begin{tabular}{|c|c|c|c|c|c|c|c|}
\hline Location & Lab ID & Sample ID & Age & Elevation & Age error & Elev. Error (m) & Source \\
\hline Hynes Brook & T12689 & PW-21-255A & 2742 & -2.55 & 64 & 0.2 & this study \\
\hline Hynes Brook & T12692 & PW-19-235A & 2729 & -2.19 & 40 & 0.15 & this study \\
\hline Hynes Brook & GX-9527 & $\begin{array}{l}\text { Hynes Brook basal } \\
\text { salt marsh }\end{array}$ & 2462 & -2.2 & 159 & 0.3 & Brookes et al., 1985 \\
\hline Hynes Brook & UQ-646 & $\begin{array}{l}\text { Hynes Brook basal } \\
\text { salt marsh B }\end{array}$ & 2985 & -3.4 & 282 & 0.3 & Brookes et al., 1985 \\
\hline Big River & & $\begin{array}{l}\text { In-core salt-marsh } \\
\text { date, uncalibrated }\end{array}$ & 950 & -1.25 & 40 & 0.3 & Wright and van de Plassche, 2001 \\
\hline Two Guts Pond & GSC-4292 & Basal salt-marsh & 2110 & -1.52 & 80 & 0.3 & $\mathbf{x}$ \\
\hline ST GEORGE & GSC-1145 & $\begin{array}{l}\text { Bog-bottom organic } \\
\text { debris, } 0 \mathrm{~m}\end{array}$ & 8158.5 & 0 & 199.5 & 0.5 & $\mathrm{x}$ \\
\hline St. George Bay & - & Lowstand & 9500 & -25 & 600 & 0.5 & $\mathbf{x}$ \\
\hline ST GEORGE & WAT-883 & $\begin{array}{l}\text { Bog-bottom organic } \\
\text { debris, St. George, } 0 \mathrm{~m}\end{array}$ & 10543 & 0 & 155 & 0.5 & $\mathbf{x}$ \\
\hline ROBHEAD 1 & GSC-1200 & Robinsons at $35.4 \mathrm{~m}$ & 16213 & 35.4 & 350 & 0.5 & $\mathbf{x}$ \\
\hline
\end{tabular}




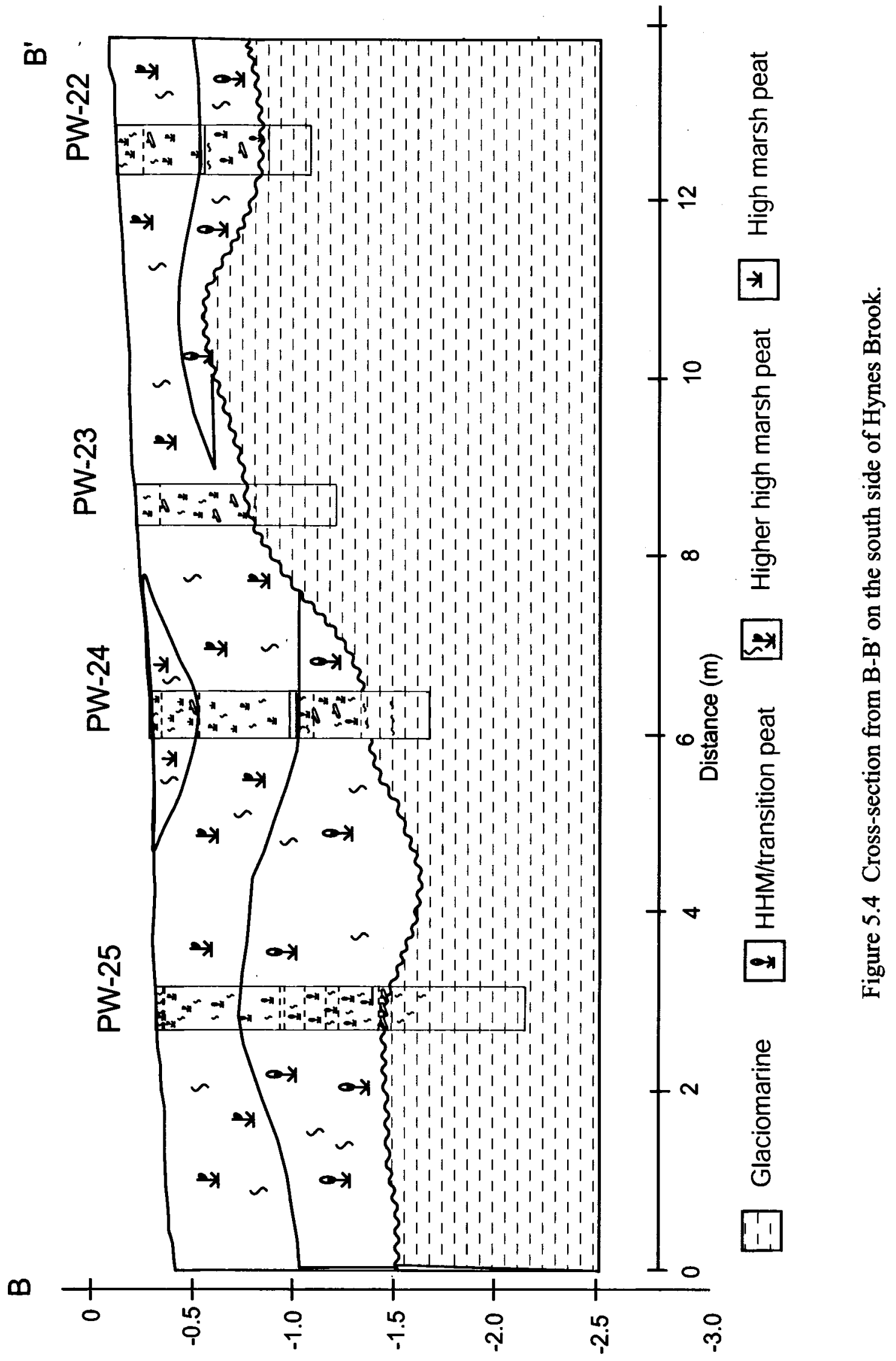




\section{Sea-level Reconstruction}

This study and other recent work (e.g., Wright and van de Plassche, 2001) improve the definition of late Holocene sea-level change in southwestern Newfoundland. Data from this and other studies concur, indicating a long-term sea-level rise of $\sim 1$ $\mathrm{mm} / \mathrm{year}$ through the late Holocene for this area (Figure 5.5). New AMS basal salt-marsh peat dates of $2742 \pm 64 \mathrm{cal}$ yr BP at $-2.55 \pm 0.2 \mathrm{~m}$ and $2729 \pm 40 \mathrm{cal}$ yr BP at $-2.19 \pm .15$ $m$ improve the temporal and vertical resolution of the oldest salt-marsh peats. Data from this study, in combination with data from Brookes et al. (1985) and Wright and van de Plassche (2001), indicate that the rate of sea-level change in southwestern Newfoundland may not have been constant over the past 3000 years. From 3000 to $2000 \mathrm{yr}$ BP the rate was $\sim 2 \mathrm{~mm} / \mathrm{yr}$. Limited data younger than $2000 \mathrm{yr}$ BP exists, but between 2000 and 1000 yr BP the rate has slowed to less than $1 \mathrm{~mm} / \mathrm{yr}$. From $1000 \mathrm{yr}$ BP to the present, sea level has risen at a slightly faster rate. The tide-gauge trend from Port-aux-Basques, $50 \mathrm{~km}$ south, if projected for the past 1700 years, does not intersect the envelope of sea-level change determined from peat ages (Figure 5.5).

The sea-level reconstruction for the late Holocene may be compared to sea-level change during the late Pleistocene through mid-Holocene (Figure 5.6). The post-glacial highstand is constrained by a shell at $+35.4 \mathrm{~m}$ dated to $\sim 13.1{ }^{14} \mathrm{C}$ kyr BP, but this may have been at tens of meters water depth. Sea level fell below present before $\sim 10.5 \mathrm{kyr}$ BP, falling to a lowstand at $-25 \mathrm{~m}$ (Shaw and Forbes, 1995). Subsequent rise to the present is constrained only by dates from the late Holocene (Figure 5.5). The rate of sealevel rise during the late Holocene is probably slower than during the early and mid- 


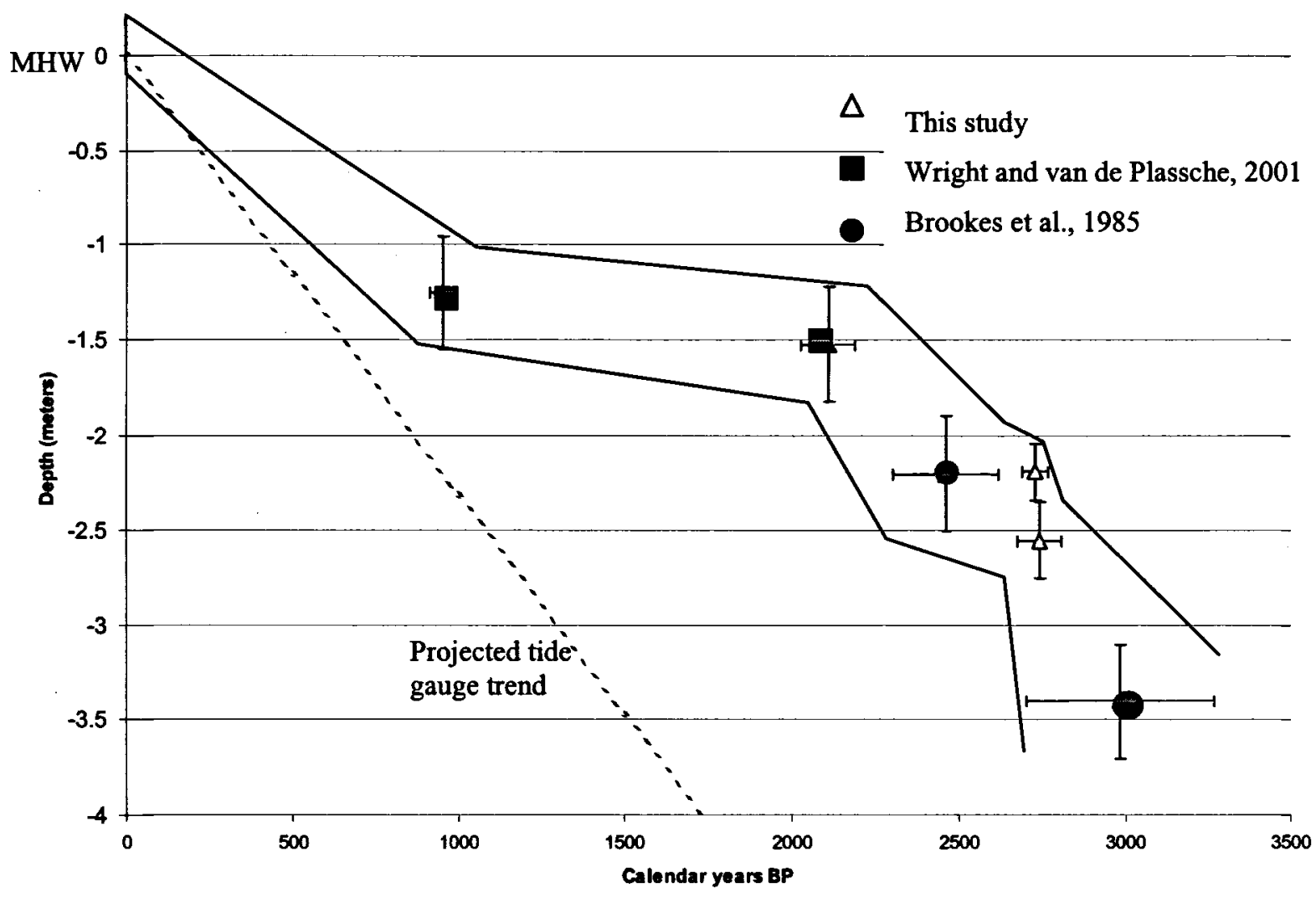

Figure 5.5 Late Holocene sea-level change in southwestern Newfoundland. Index points are from basal salt-marsh peats sampled in this and published studies. Vertical and temporal error bars indicate the uncertainty associated with each index point. These points are used as the basis for the construction of an envelope of sealevel change at this location. 


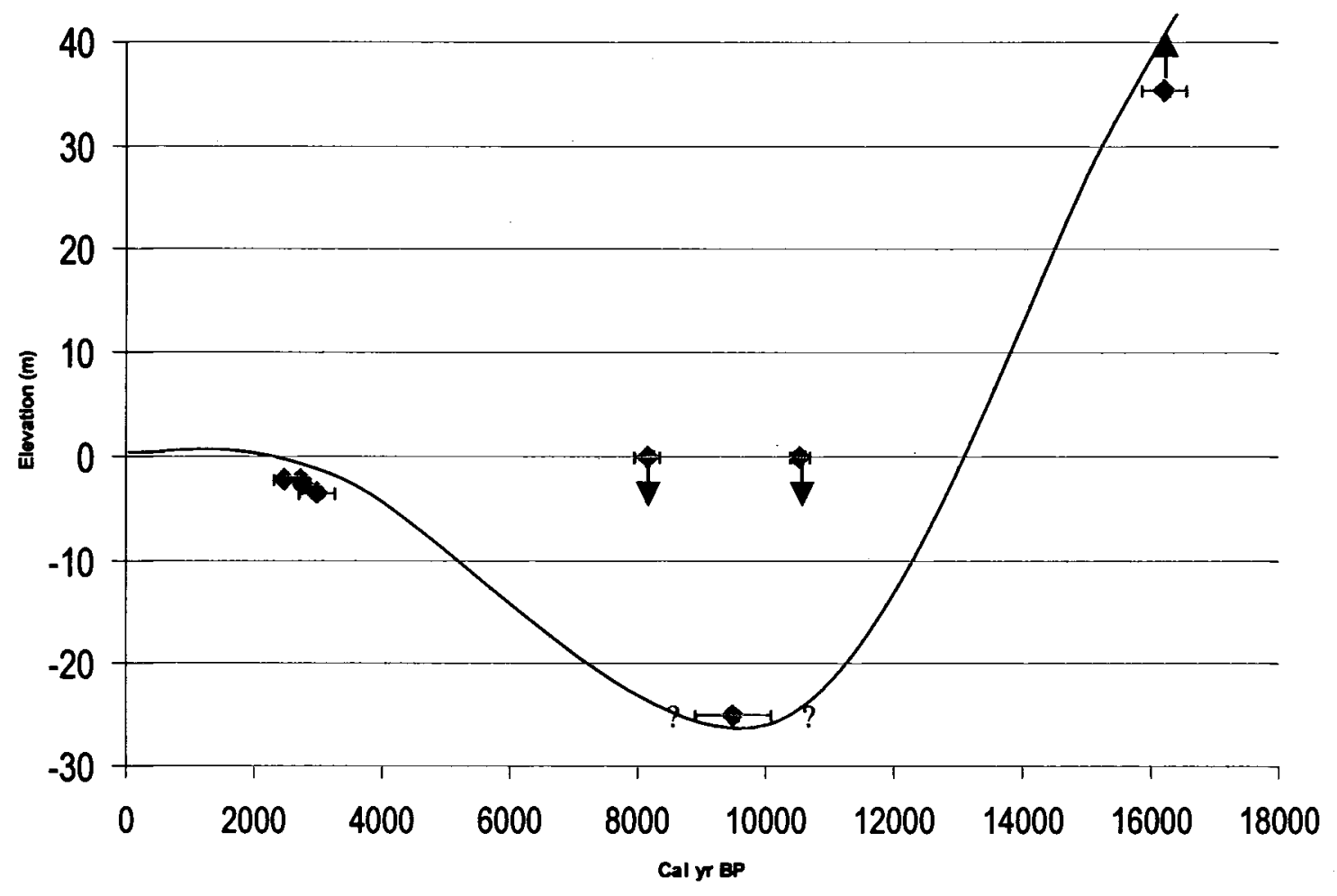

Figure 5.6 Post-glacial sea-level change in southwestern Newfoundland. Data are from this and previously published research. Arrows indicate that an index point is above or below datum. The lowstand is undated; lateral error bars approximate the age. The sea-level curve interpreted from this data is consistent with a B-type curve (Quinlan and Beamumont, 1982) but is poorly constrained except in the late Holocene. 
Holocene, but the absence of index points between 5000 and 10,000 years ago precludes any significant comparison.

\section{Discussion}

Late Holocene sea-level change in this area does have the predicted B-type sealevel history, but the magnitide and timing do not agree well with numerical models. This is the first calibrated timescale used to re-construct sea-level change in this region. Calibration influences the shape of the sea-level curve because calibrated late Pleistocene and early Holocene dates are significantly older than their associated raw radiocarbon ages. Calibration of the dates should ease comparisons between model predictions and data.

Limited data for the late Holocene indicate sea-level rise at variable rates. Bulk and AMS ${ }^{14} \mathrm{C}$ dates from basal peats agree, although the AMS dates are slightly older than conventional dates at comparable depths. Few data are available for the latest Holocene, making comparisons with the tide-gauge record difficult. Based on available data, the rate of rise since $1000 \mathrm{yr} \mathrm{BP}(1.25 \mathrm{~mm} / \mathrm{yr})$ is slightly slower than the rate calculated from the Port-aux-Basques tide gauge $(2.3 \mathrm{~mm} / \mathrm{yr})$. This may be an artifact of the data, or may represent a real trend in sea-level change from south to north along the western coast of the island.

The salt-marsh stratigraphy primarily represents a simple transgressive succession. Sections of high marsh or higher high marsh peat unconformably overlie glaciomarine sediments and alluvium. At the fringes of the marsh, some freshwater deposits are preserved above the glaciomarine sediments. Subsequent transgression has 
buried these with salt-marsh peat. Variations in the salt-marsh stratigraphy may be explained by changes in the rate of sea-level rise or barrier - inlet dynamics. The widespread unit of transitional peat found at $\sim 0.6-1 \mathrm{~m}$ below the marsh surface may have developed during a period when marine influence became restricted by the partial closure of the inlet due to barrier migration. Alternatively, this unit may have developed during a period of slowing sea-level rise, or slowing sea-level rise led to increased progradation of the barrier and restriction of the inlet. These questions cannot be resolved based solely on these data. 


\section{Chapter 6}

\section{ST. PAUL'S INLET \\ Introduction and Geologic Setting}

St. Paul's Inlet is located on the western coast of Newfoundland at $50^{\circ} \mathrm{N}$ latitude and $57^{\circ} \mathrm{W}$ longitude. Underlying platform sediments of the Paleozoic Cow Head Group define headlands and pinning points of the local coastal systems. The inlet is bounded by extensive barrier-spit systems on the north and south sides (Figure 6.1). During this study I investigated only the southern side of the inlet. Erosion of glacigenic deposits updrift of either barrier system supplies sediment to the barriers. At present, the barrierspit on the southern side of the inlet is eroding on its seaward side. This erosion and migration of the barrier eastward is exposing the underlying bedrock and creating a wave-cut platform (Figure 6.2). Grain size of the active barrier ranges from cobble to fine sand, fining distally. There is an active flood-tidal delta in the inlet, forcing the inlet thalweg toward the southern spit.

The backbarrier morphology of the southern spit is complex (Figure 6.1). Small channels dissect the backbarrier area, and the low-lying sandy deposits may be relict flood-tidal delta sands. Mean tidal range at this location is probably $\sim 1 \mathrm{~m}$, based on predictions for Portland Cove, $40 \mathrm{~km}$ to the north, by the Canadian Hydrographic Service (Table 6.1). A thin salt-marsh peat extends over much of the backbarrier area (Figure 6.2). The salt-marsh flora transforms laterally to an upland grassland. Parts of this grassland are used to graze sheep in the fall. Hummocky ground adjacent to these pens is probably related to herding of the sheep through this area. Unusual features of this marsh are the numerous boulders on the marsh surface (Figure 6.3). The marsh has grown up 


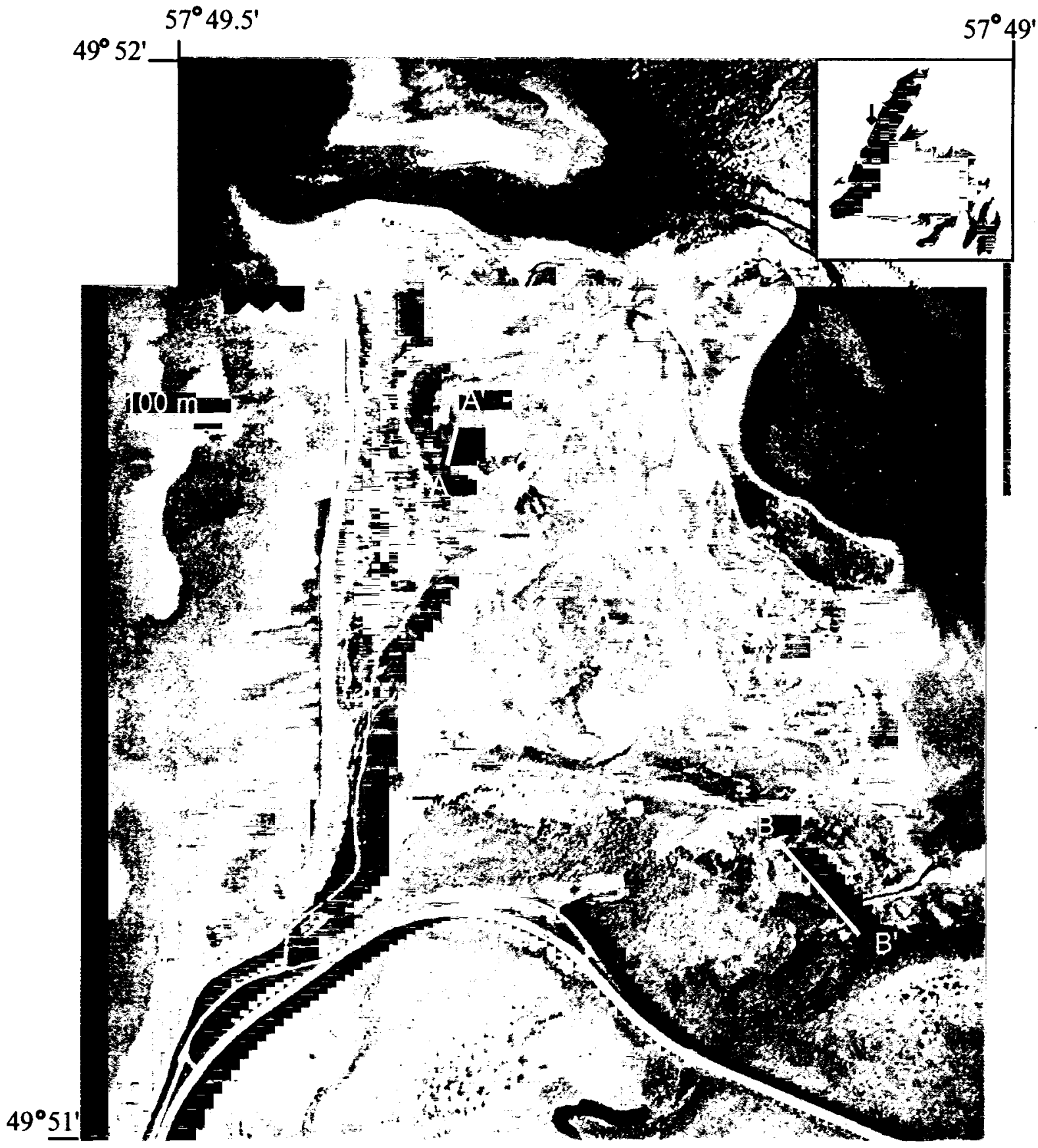

Figure 6.1 Aerial photo of the south side of St. Paul's Inlet. 


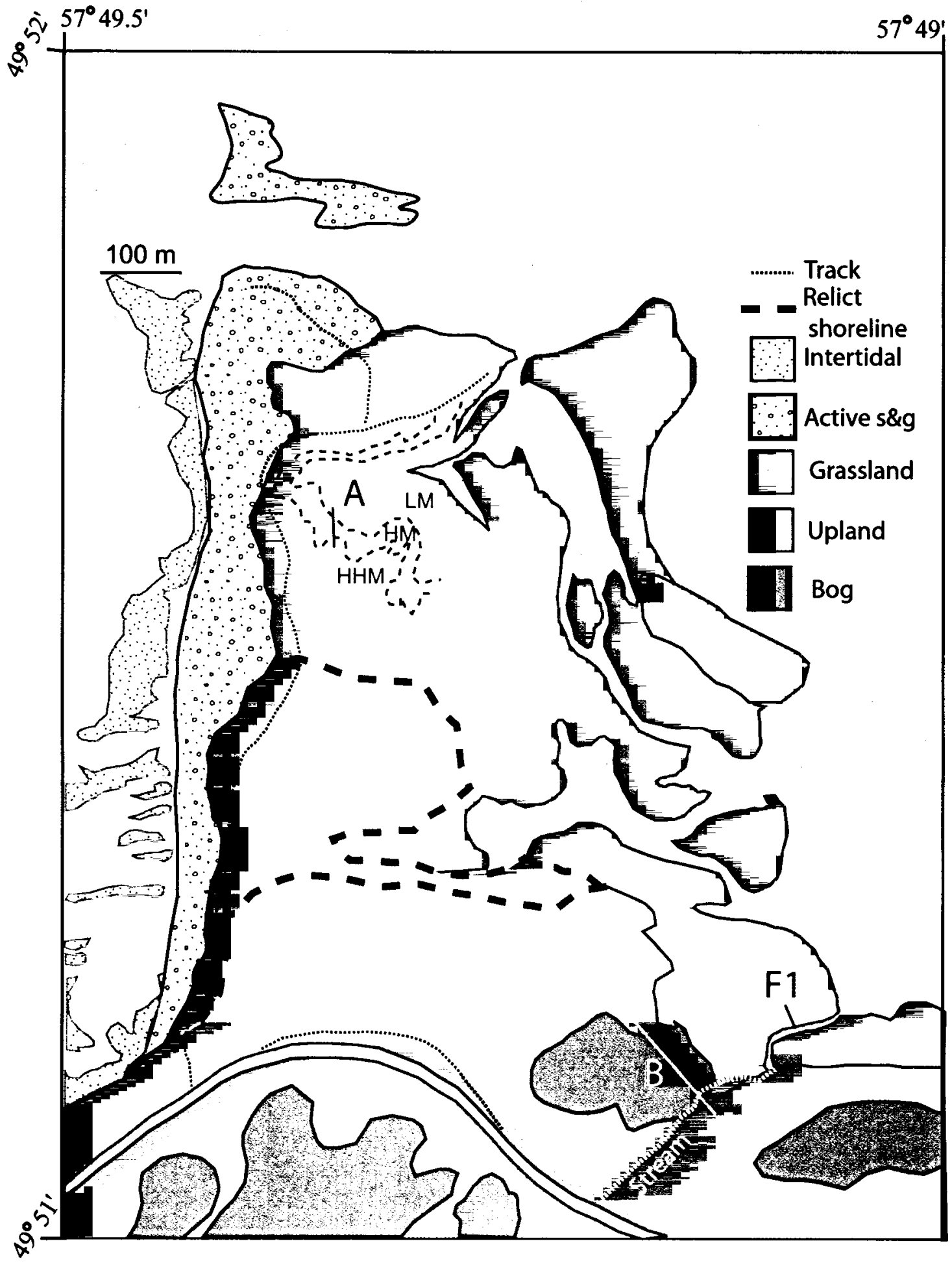

Figure 6.2 Generalized geomorphic map of St. Paul's Inlet. Transects A and B are indicated by lines. F1 is the southeastern surface sample transect. 


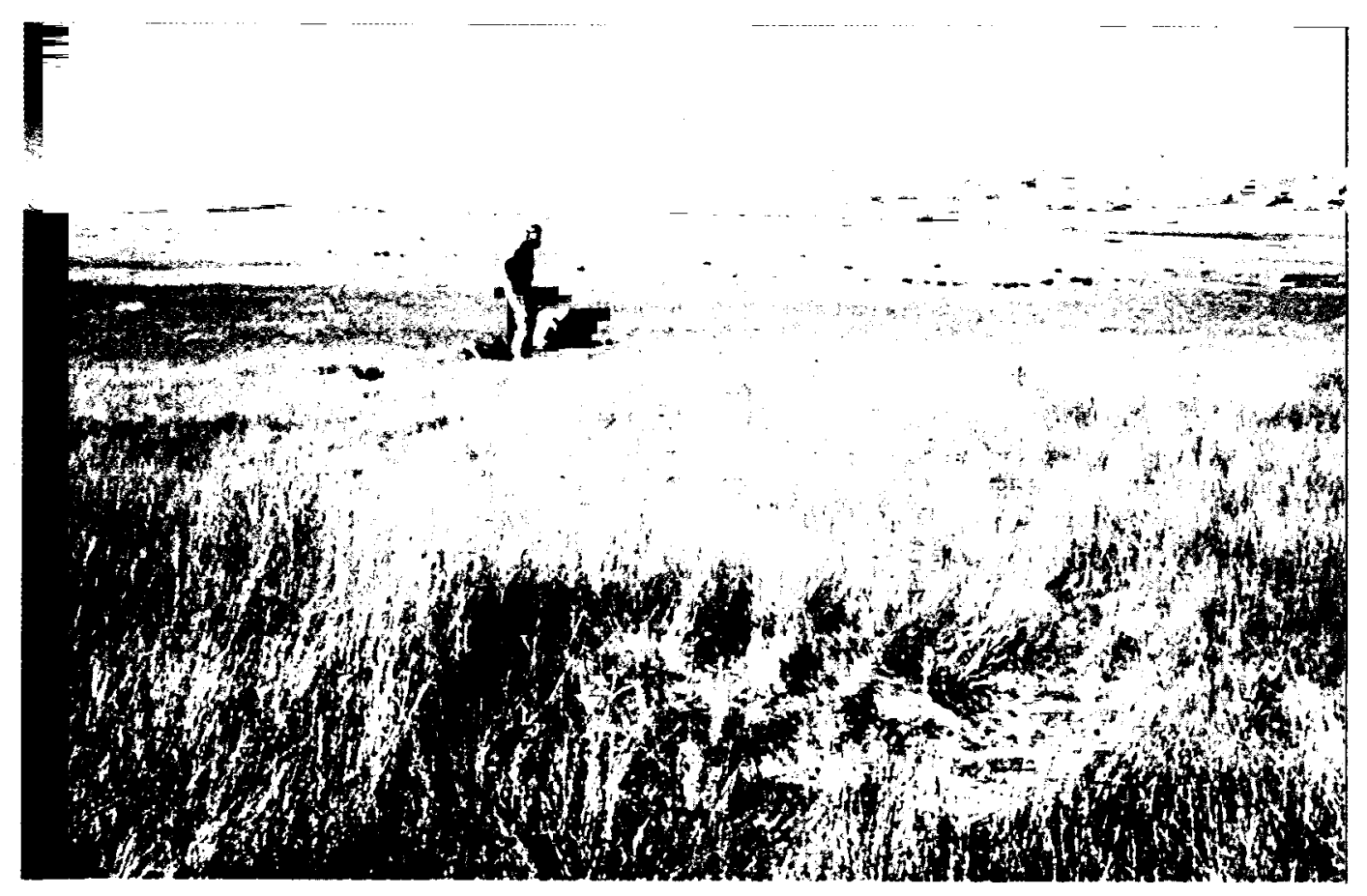

$=$

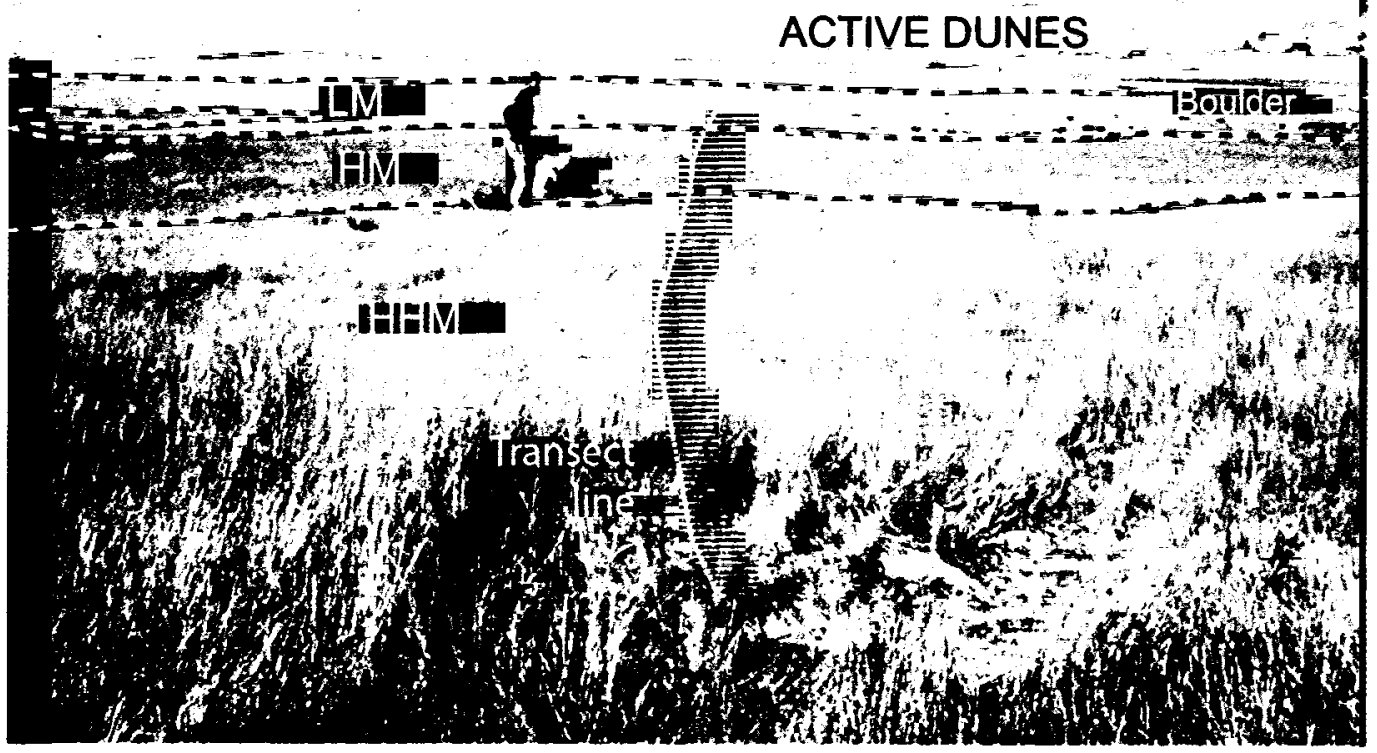

Figure 6.3 Barrier transect at St. Paul's Inlet, view north toward Inlet. Large boulders overlie peats, indicating ice rafting. Note the unusually large Triglochin maritima in the background. 
around some of the boulders, suggesting that they are erosional remnants of till that has mostly been re-worked. However, some of the boulders overlie peat deposits, indicating that they may have been emplaced by ice and that ice rafting may be significant in this location.

Table 6.1 Tidal range projections for Portland Cove (Canadian Hydrographic Service, 1999).

\begin{tabular}{lll}
\hline & & Location \\
\hline Mean tidal range & $1.09 \mathrm{~m}$ & Portland Cove \\
Spring tidal range & $1.40 \mathrm{~m}$ & Portland Cove \\
Projected tidal range & $1.44 \mathrm{~m}$ & Portland Cove \\
\hline
\end{tabular}

Several relict higher-than-present shorelines can be traced along the southern margin of the inlet (Figure 6.2). One shoreline, 3-5 m above present, defines the broad flat area to the south of the Inlet. It is roughly traced by the path of Rt. 430 and is locally vegetated by large bogs. At a slightly lower elevation, $\sim 2 \mathrm{~m}$ asl, another shoreline can be traced along the proximal edge of the southern spit.

Although there is very little relief across the marsh, surficial vegetation in this study area is zoned (Figure 6.3). Floral and microfaunal zonations are summarized in Table 6.2, and discussed in more detail in Chapter 4. The low-marsh vegetation is characterized by unusually large Triglochin maritima surrounded by a dwarf Eleocharis or Carex species (Figure 6.4). Low marsh peat is fibrous and nearly $100 \%$ organic. The foraminiferal zone associated with the low marsh is dominantly $J$. macrescens, with $M$. fusca, T. comprimata, and Haplophragmoides sp. In the high marsh zone, the dominant vegetation is Eleocharis (halophila?) species, forming a fibrous peat (Figure 6.4). The high marsh is associated with a less diverse foraminiferal population composed of $J$. macrescens and M. fusca. The highest high marsh is vegetated by Juncus gerardii and a Potentilla species, forming a dark brown fibrous peat. Foraminiferal populations are very 

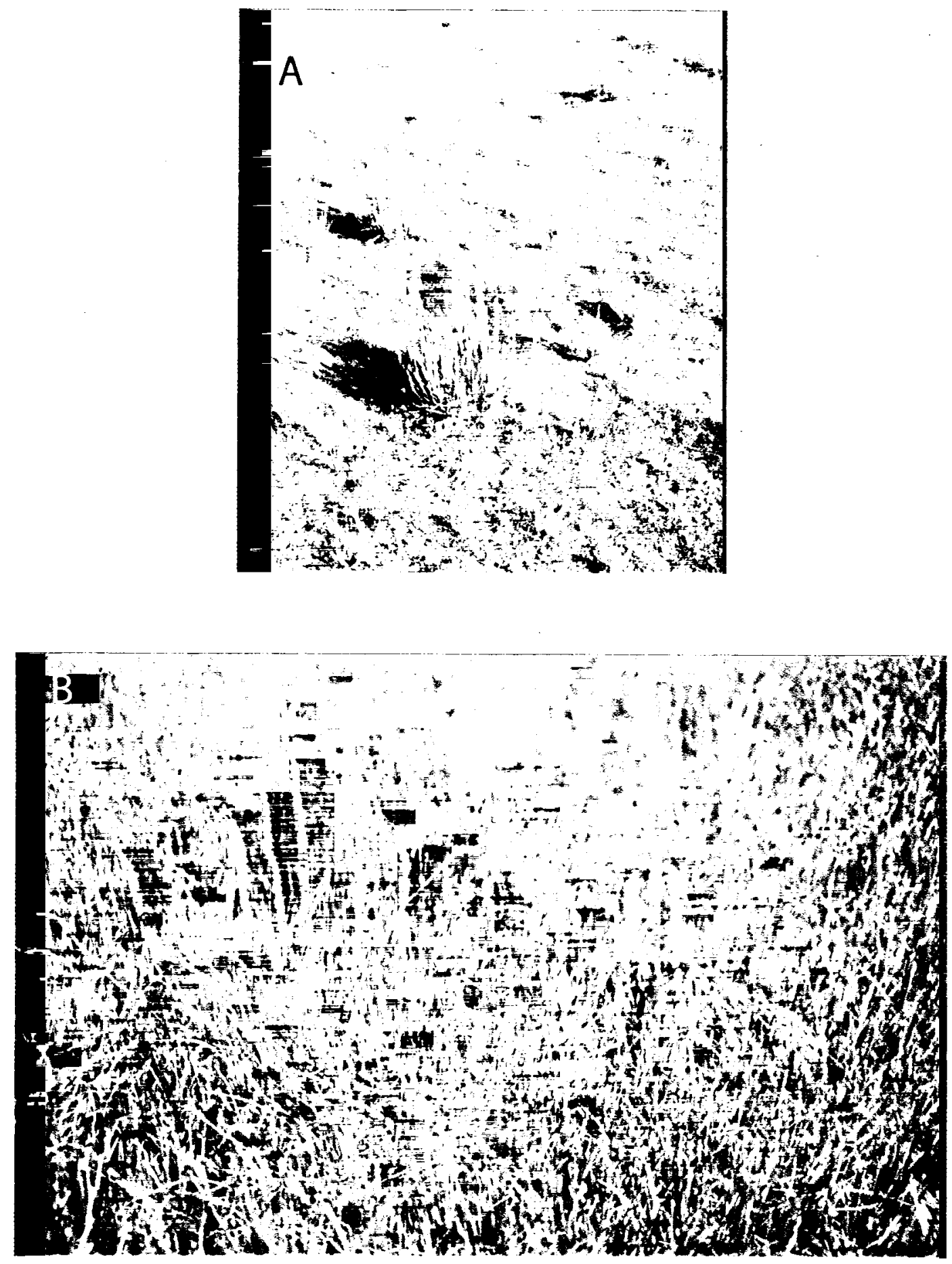

Figure 6.4 Plants from the low and high marsh at St. Paul's Inlet. A) Unusually large Triglochin maritima in the low marsh area surrounded by a stunted Eleocharis (?) sp. B) Triglochin maritima in the high marsh area surrounded by Eleocharis halophila (?), the rush common in the high marsh zone. 
low in this zone, and are dominated by $B$. pseudomacrescens with $J$. macrescens and a few species as minor components. Surficial samples from the upper part of the higher high marsh did not have any foraminifera. Iris versicolor marks the upper limit of tidal influence and the transition to upland grasses, similar to the zonation of Hynes Brook.

Table 6.2 Salt-marsh floral and microfaunal zones at St. Paul's Inlet

\begin{tabular}{llll}
\hline Zone & Elevation & Flora & $\begin{array}{l}\text { Dominant } \\
\text { Foraminifera }\end{array}$ \\
\hline Upland & $>0.45 \mathrm{~m}$ & $\begin{array}{l}\text { Forest, upland grasses, } \\
\text { boundary marked by Iris sp. }\end{array}$ & None \\
& & Sphagnum sp. & None \\
Bog & $>0.45 \mathrm{~m}$ & Juncus gerardii & B. pseudomacrescens \\
$1 \mathrm{a}(\mathrm{HHM})$ & $0.3-0.45 \mathrm{~m}$ & Elech \\
1b (HM) & $0.15-0.3 \mathrm{~m}$ & Eleocharis halophila (?) & J. macrescens \\
$2 \quad(\mathrm{LM})$ & $0-.15 \mathrm{~m}$ & Eleocharis sp., T.maritima & J. m., B. p. \\
\hline
\end{tabular}

\section{Previous Work}

Limited previous research on sea-level change has been completed at this site.

One shoreline, at $\sim 1.5 \mathrm{~m}$ asl, yielded a shell with a radiocarbon date of $\sim 250 \mathrm{yr} B P$ (Grant,1977). It is possible, however, that this shell was not in situ and was deposited during a storm (Liverman, 1994). At Cow Head, seven kilometers to the north, rockboring Hiatella arctica valves (in growth position) associated with a gravel terrace at $8 \mathrm{~m}$ asl yield uncorrected radiocarbon dates of $8250 \pm 320{ }^{14} \mathrm{C}$ yr BP (Brookes and Stevens, 1985). This date is interpreted to represent the death of the organisms due to erosion or gravel deposition over the boreholes as sea level fell below this elevation. Other dates from the region are on similar shells associated with emergent coastal features. Growthposition Mytilus edulis at $4 \mathrm{~m}$ asl from the mouth of Western Brook, $\sim 5 \mathrm{~km}$ southwest of St. Paul's Inlet, yielded an uncorrected date of $8340 \pm 150{ }^{14} \mathrm{C}$ yr BP and are interpreted to represent the age of the $+6 \mathrm{~m}$ shoreline at this location (Lowden et al., 1977). Growth- 
position Mytilus edulis collected at $8 \mathrm{~m}$ asl at Parsons Pond, $20 \mathrm{~km}$ northeast of St. Paul's Inlet, yielded an age of $8650 \pm 140{ }^{14} \mathrm{C}$ yr BP (Lowden et al., 1977). Dates of $1700-4130$ ${ }^{14} \mathrm{C}$ yr BP are associated with archeological sites on Cow Head, but are not definitively related to sea level (Tuck, 1982, in Brookes and Stevens, 1985). The lowest elevation site, $2.9 \mathrm{~m}$ asl, dated to $\sim 2700{ }^{14} \mathrm{C}$ yr BP, but is not a good sea-level indicator because of the uncertainty of the association to sea level.

\section{$\underline{\text { Results }}$}

\section{Salt-marsh Stratigraphy}

Cores were taken along two transects at this location (Figure 6.1). Exploratory cores collected throughout the area indicated where the longest, most continuous records might be found. One transect is located in the backbarrier, parallel to the modern seaward coast (barrier transect). The transect begins in the high marsh (HM) and terminates in the upper higher high marsh (HHM) (Figure 6.5). The other transect is located to the southeast of the barrier transect, crossing a bog and terminating in upland forest (bog transect) (Figure 6.6).

Cores collected along the barrier transect are all less than one meter in length. A cross-section constructed from these cores reveals alternating peat and sand units (Figure 6.7). Medium-fine, well-sorted sands at the southern end of the transect are conformably overlain by by as many as three peat units. The lowest peat was found only in the southernmost core (SPI-30), and is a fibrous HM peat. It is overlain by sand approximately $0.10 \mathrm{~m}$ thick, which in turn is overlain by another fibrous HM peat. This

peat unit may be correlated among four cores, varying between $8-15 \mathrm{~cm}$ thick. The upper 

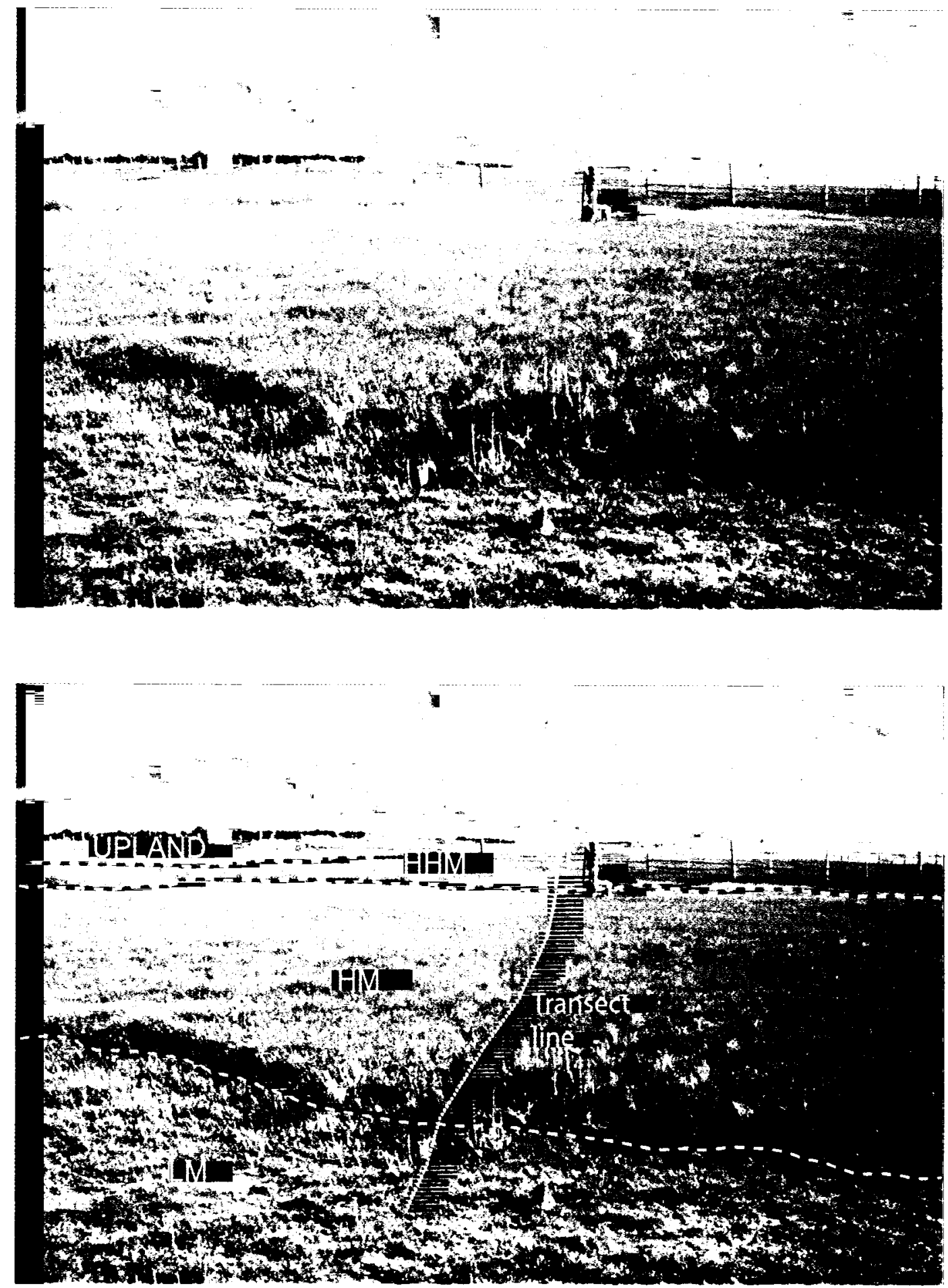

Figure 6.5 Barrier transect at St. Paul's Inlet, view south-southeast. Long Range in the background. Fenced areas are used seasonally for sheep grazing. 


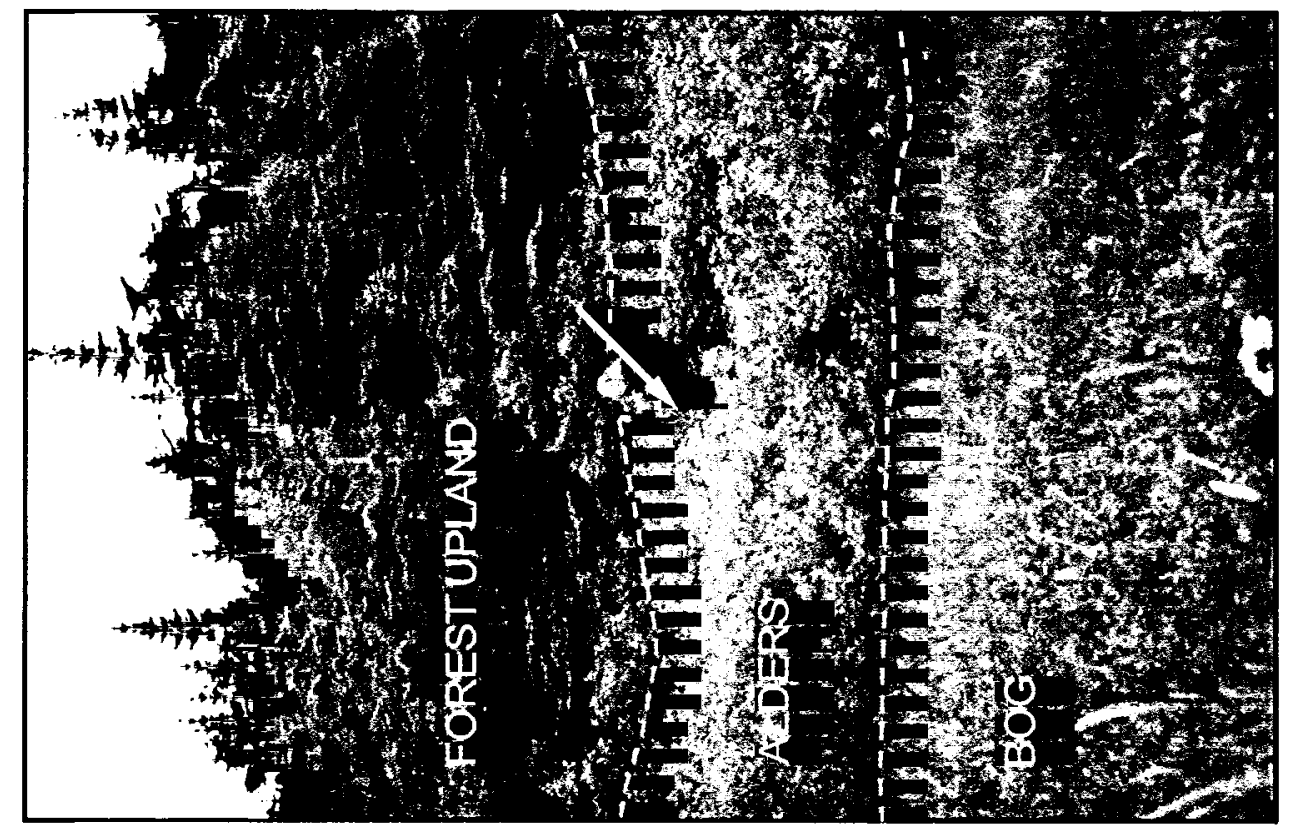

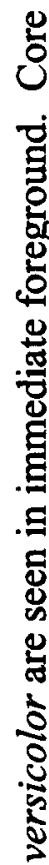

运

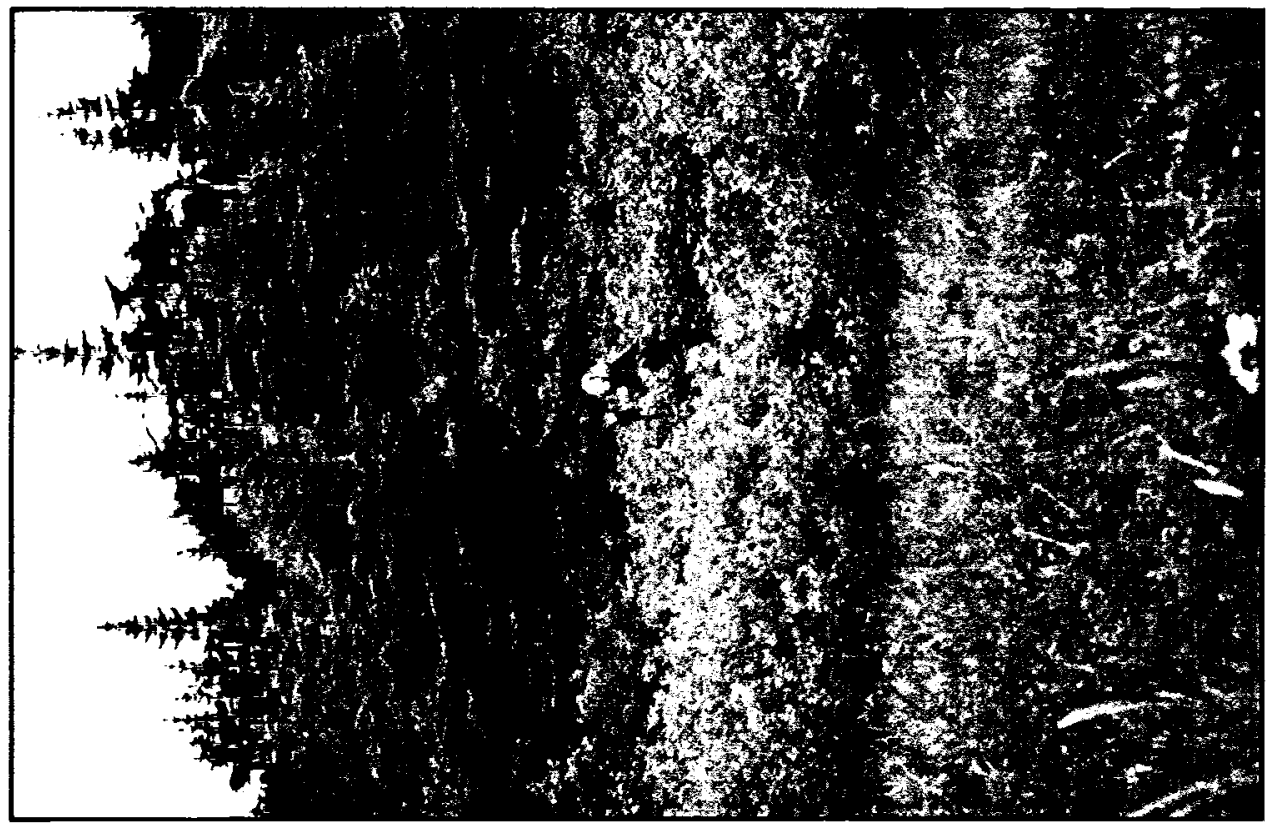

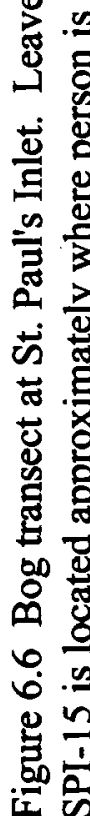




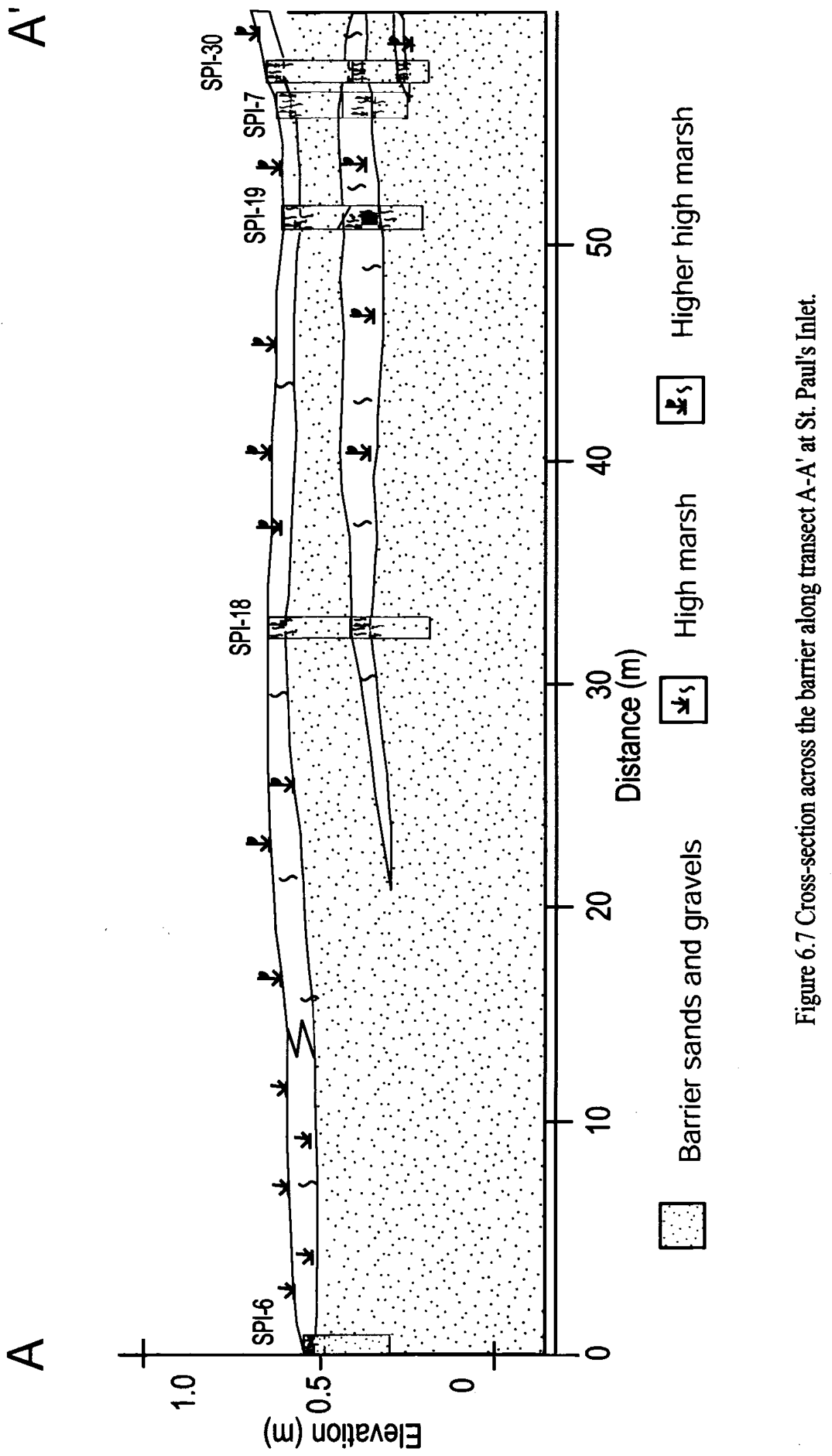


contact between this HM peat and overlying sand is sharp. The overlying sand unit is 0.2 to $0.3 \mathrm{~m}$ thick, and is conformably overlain by the thin surficial peat unit. This repetitive stratigraphy is interpreted to represent a washover sequence. Salt marshes initially colonized the barriers, were buried and/or eroded by overwash events (represented by the sharp upper peat contact), and subsequently re-established when the tidal regime flooded the surface of the washover fan frequently enough.

The bog transect is located less than a kilometer to the southeast, bounded on either end by upland forest and crossing a freshwater bog (Figure 6.8). Cores collected along this transect are also less than one meter long. The basal unit is sand, fine-grained and well-sorted in some areas and moderately sorted across the middle of the transect. Exploratory cores in this area showed that the sand unit underlying the bog is moderately sorted and includes shell fragments. This sand is unconformably overlain by a fibrous upland peat and then a detrital peat $\sim 0.5 \mathrm{~m}$ thick.

At either end of the transect, limited foraminifera-rich high-marsh peats overlie the sands. These limited units are conformably overlain by a fibrous upland peat that unconformably overlies the sands at slightly higher elevations. This fibrous upland peat is conformably overlain by detrital freshwater peat and, at the eastern end of the transect, an upland soil associated with a conifer forest. On the eastern end of the profile, small lenses of reworked mud overlie the salt marsh peat units, and the basal stratigraphy of the cores collected in the alder and upland forest zones is complex. The units are thin (1-3 $\mathrm{cm}$ thick), but the salt-marsh peat identified by the presence of foraminifera appears to have roots extending down from the peat into the underlying sand, suggesting that it is in place. On the western end of the profile, the stratigraphy is more continuous, and the 


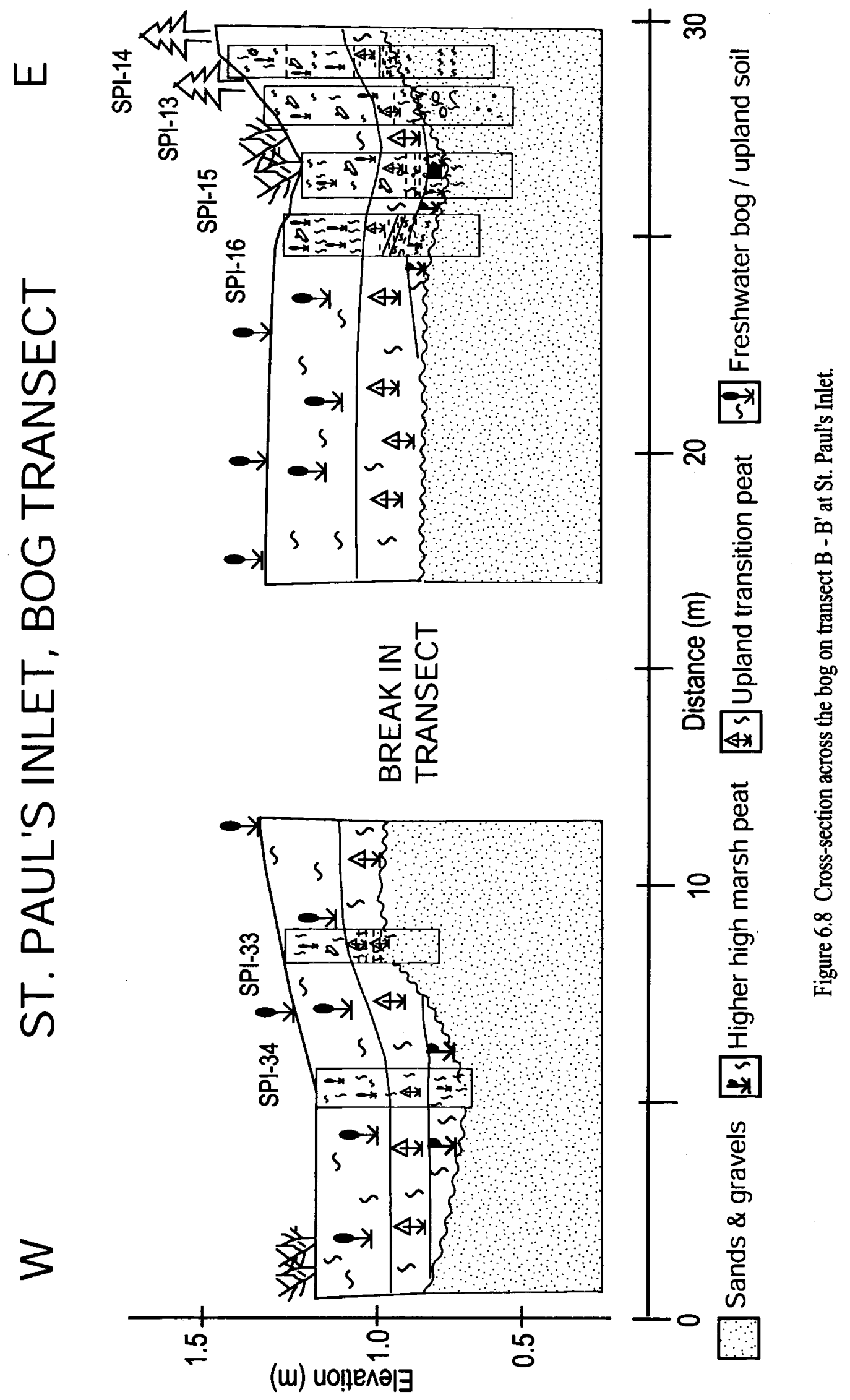


foraminifera-rich peat conformably gives way to a non-marine peat. The salt marsh units identified at depth are at the same elevation and have similar foraminifer assemblages, and may be correlated to each other across the transect.

\section{$\underline{\text { AMS }{ }^{14} \mathrm{C} \text { Dates }}$}

A complete report of the data associated with these radiocarbon dates and calibrations is included in Appendix II. Seven AMS ${ }^{14} \mathrm{C}$ dates were obtained for samples from St. Paul's Inlet. The sampled sites are indicated on the transect cross-sections, and results are summarized in Table 6.3. Three of these seven returned post-bomb signatures. Ages for the remaining samples range from $\sim 450$ yr BP to $\sim 1850$ yr BP. For the reconstruction of sea-level changes at this location, six of the dates are considered. The sample that is not included is explained below.

Samples were taken from cores along both transects. Three samples were dated from the barrier transect. Core numbers are given in parentheses. The lowest peat was sampled (SPI-30) and returned a post-bomb age. The middle peat unit (SPI-18) was dated to $\sim 1100 \mathrm{yr}$ BP, and the surface peat (SPI-19) yielded a post-bomb (A.D. 1950) age. The middle peat age of $\sim 1100 \mathrm{yr} \mathrm{BP}$ is considered a viable age, and the 'postbomb'age of the lowest peat unit is not considered correct. If this sample was correctly labelled in the field, it is possible that it was contaminated by humic acids in groundwater (e.g., Belknap et al., 1987). This age is not included in the reconstruction of local sealevel change.

Four samples were dated from cores along the bog transect. Three samples (core numbers in parentheses) were taken from salt-marsh units with high foraminiferal counts, yielding ages of $\sim 1850 \mathrm{yr} \mathrm{BP}$ (SPI-15), $\sim 450 \mathrm{yr}$ BP (SPI-34), and post-bomb (SPI-16). 
The remaining sample was submitted from a unit identified as 'transitional' which had a very low foraminiferal count and dated to $\sim 1170$ yr BP (SPI-33). The two oldest dates are considered viable; the two younger dates are somewhat problematic. The post-bomb date is from a core adjacent to the oldest date, from a comparable elevation, beneath tens of centimeters of peat. It is possible that this was a root that penetrated the overlying peat, then extended along a flat bedding plane within the buried peat and was misidentified as detrital. The $\sim 450 \mathrm{yr}$ BP date is from a core on the northwest end of the transect, adjacent to the $\sim 1170 \mathrm{yr}$ BP date. It is from a lower elevation than the older date, and the transitional sedge unit associated with the older date conformably overlies the salt-marsh peat yielding the younger date. It is possible that this is another case of contamination; other explanations may be appropriate.

Table 6.3 Radiocarbon data for St. Paul's Inlet.

\begin{tabular}{llllllll}
\hline Transect & Lab ID & Sample ID & Age (cal yr BP) & Elevation (m) & Zone & Sample description \\
\hline Bog & TO-8745 & SPI-15-38A & $1833 \pm 116$ & $0.42 \pm 0.1$ & 2 & Detrital Alnus bark fragment \\
Bog & T12695 & SPI-16-41A & Post-bomb & $0.43 \pm 0.1$ & 2 & Detrital (?) Juncus \\
Barrier & TO-8746 & SPI-18-29A & $1115.5 \pm 69.5$ & $-0.06 \pm 0.1$ & 2 & Detrital Scirpus \\
Barrier & T12694 & SPI-19-10A & Post-bomb & $0.05 \pm 0.1$ & 2 & Detrital grass \\
Barrier & & SPI-30-37 & Post-bomb & $-0.14 \pm 0.1$ & 2 & Detrital grass \\
Bog & & SPI-33-27 & $1170 \pm 117$ & $0.39 \pm 0.3$ & Trans. & Detrital grass \\
Bog & T14376 & SPI-34-42 & $465 \pm 35$ & $0.30 \pm 0.1$ & 2 & Detrital grass \\
\hline
\end{tabular}

\section{Discussion}

The stratigraphies of the barrier and bog transects suggest different sea-level trends. The repetitious stratigraphy of the barrier transect (Figure 6.7) is a transgressive stratigraphy and is interpreted to represent recent local sea-level rise. The bog transect (Figure 6.8) has a regressive stratigraphy which may result from a) local relative sea-level fall or b) increasing isolation from marine influence as the barrier prograded north. These two hypotheses are not mutually exclusive. The elevation of the salt-marsh units 
in the barrier transect is $\sim 0.4 \mathrm{~m}$ greater than the modern marsh with a comparable foraminiferal assemblage. At this location, this difference is greater than the elevation range of that foraminiferal zone. This evidence supports the hypothesis of local relative sea-level fall.

The AMS ${ }^{14} \mathrm{C}$ dates may resolve the apparent opposing stratigraphic evidence. The oldest date is associated with the bog transect, and some of the younger dates are associated with the barrier transect. Two sea-level change reconstructions are shown in Figure 6.89. In Reconstruction One, four of the five data points are connected to indicate sea level falling continuously to present. Reconstruction Two uses three data points, and shows sea level falling till $\sim 1000 \mathrm{yr} \mathrm{BP}$, then rising slowly $(<0.1 \mathrm{~mm} / \mathrm{yr})$ to the present. The latter reconstruction better fits the stratigraphic evidence and is the preferred hypothesis.

Reconstruction 2 better defines the passage of sea level below present at this site and the location of the hinge line between falling and rising sea level. Previous research in this region utilized marine shells in emergent coastal features to define the passage of sea level below present. This study adds control for the late Holocene to existing the data. Previous interpretations of Holocene sea-level change for this area projected that sea level passed below present shortly after $800014 \mathrm{C}$ yr BP based on the rates of change from the early Holocene (Brookes and Stevens, 1985). The addition of late Holocene data indicating that sea-level fell below present at this location as recently as $\sim 1000 \mathrm{yr}$ BP provides a more complete picture of sea-level change along the Northern Peninsula. Based on the early- mid Holocene data, it is difficult to understand why the hinge line would have 'stalled' somewhere along the Northern Peninsula during the Holocene 


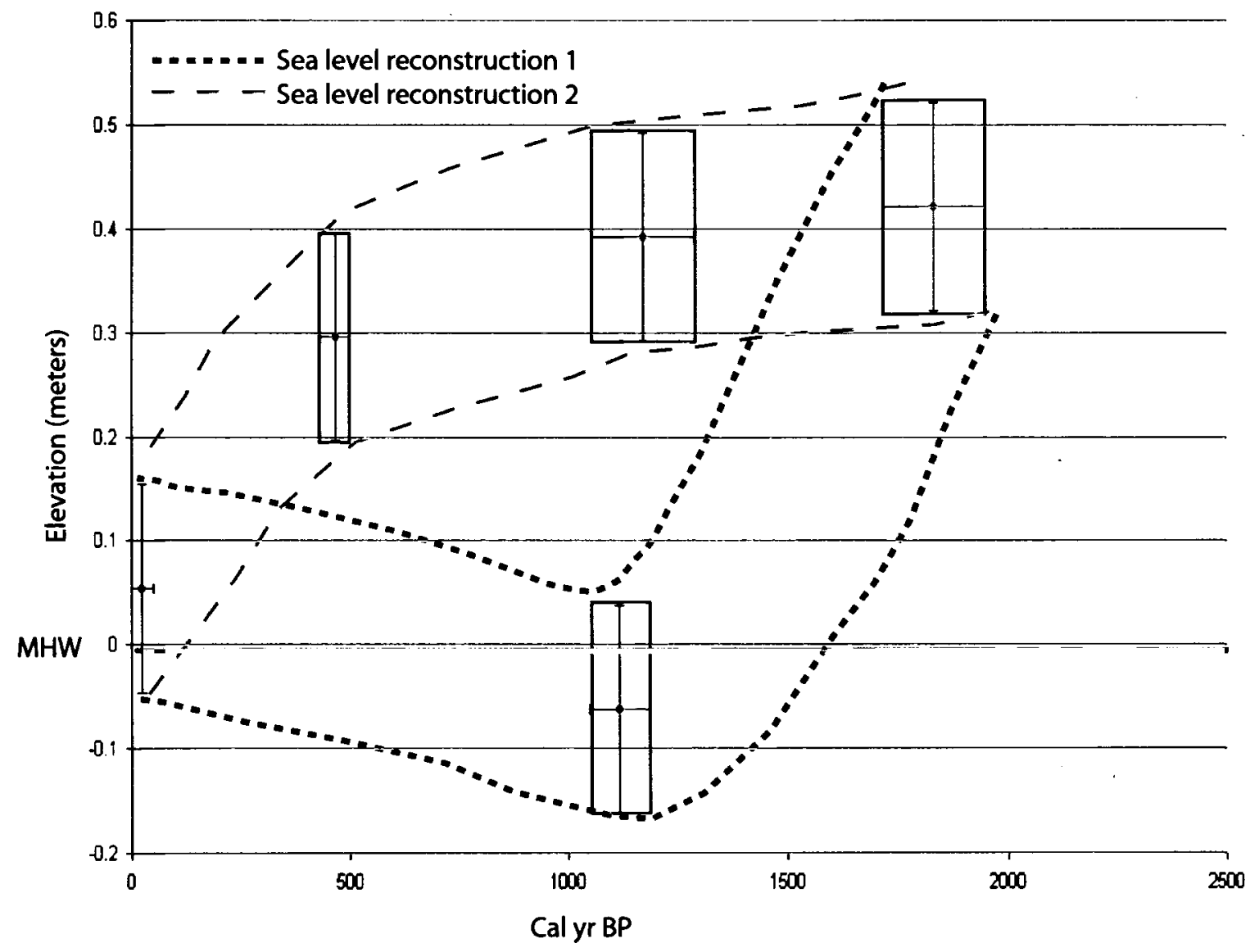

Figure 6.9 Sea level reconstructions for St. Paul's Inlet based on new AMS ${ }^{14} \mathrm{C}$ dates. Sea level reconstruction 1 is favored by the stratigraphic record that indicates recent sea-level rise but excludes several data points. Sea level reconstruction 2 includes more of the available data points. MHW is indicated by a heavy gray line. 
(Liverman, 1994). If, in fact, it passed through here relatively recently, it is easier to understand why the northern end of the Northern Peninsula continues to emerge and why the coast of Quebec and Labrador only slightly northwest of the study site are also slowly emergent. Previous interpretations of sea-level change in this area suggested that sea level fell slightly below present during the early Holocene, rose above present during mid-Holocene, then fell to the present (Grant, 1989). Based on the data presented here for the late Holocene, this sea-level history cannot be ruled out. 


\section{Chapter 7}

\section{DEADMAN'S BAY}

\section{Introduction and Geologic Setting}

Deadman's Bay is a large, swash-aligned sandy barrier located at $49^{\circ} 20^{\prime} \mathrm{N}$ and $53^{\circ} 43^{\prime} \mathrm{W}$ in northeastern Newfoundland (Figure 7.1). The region is underlain by granite, and is characterized by low topographic relief and large, progradational barriers and capes. Numerical models predict a type B sea-level curve for this area (Quinlan and Beaumont, 1981). No obvious glacigenic sediment sources for the barriers were identified, but the sediment may be recycled from sources now submerged on the inner shelf (Shaw and Forbes, 1990).

Deadman's Bay barrier is $\sim 2.5 \mathrm{~km}$ long, with a narrow but deep inlet at the southeastern end (Figure 7.2). It is composed of well-sorted medium-fine grained sand. Active and inactive washover fans line the barrier (Shaw and Forbes, 1990). Inactive fans are heavily vegetated by marsh, bog, or conifer forest. Previous research identified deep channels incised at the northwestern end of the barrier that are interpreted as floodtidal channels that subsequently filled with organic pond sediments (Shaw and Forbes, 1990). Depressions in these channel fills form small ponds. Peat overlying these channels in some areas is saturated, and cracks in the marsh surface may be the result of recent slow soil creep over permafrost (Figure 7.3). Ice-push ridges are present along part of the lagoon margin (Figure 7.4)

Mean tidal range in this area is extrapolated to be $0.67 \mathrm{~m}$ based on projections for Valleyfield, $\sim 25 \mathrm{~km}$ south where spring tidal range is $0.88 \mathrm{~m}$ (Canadian Hydrographic 


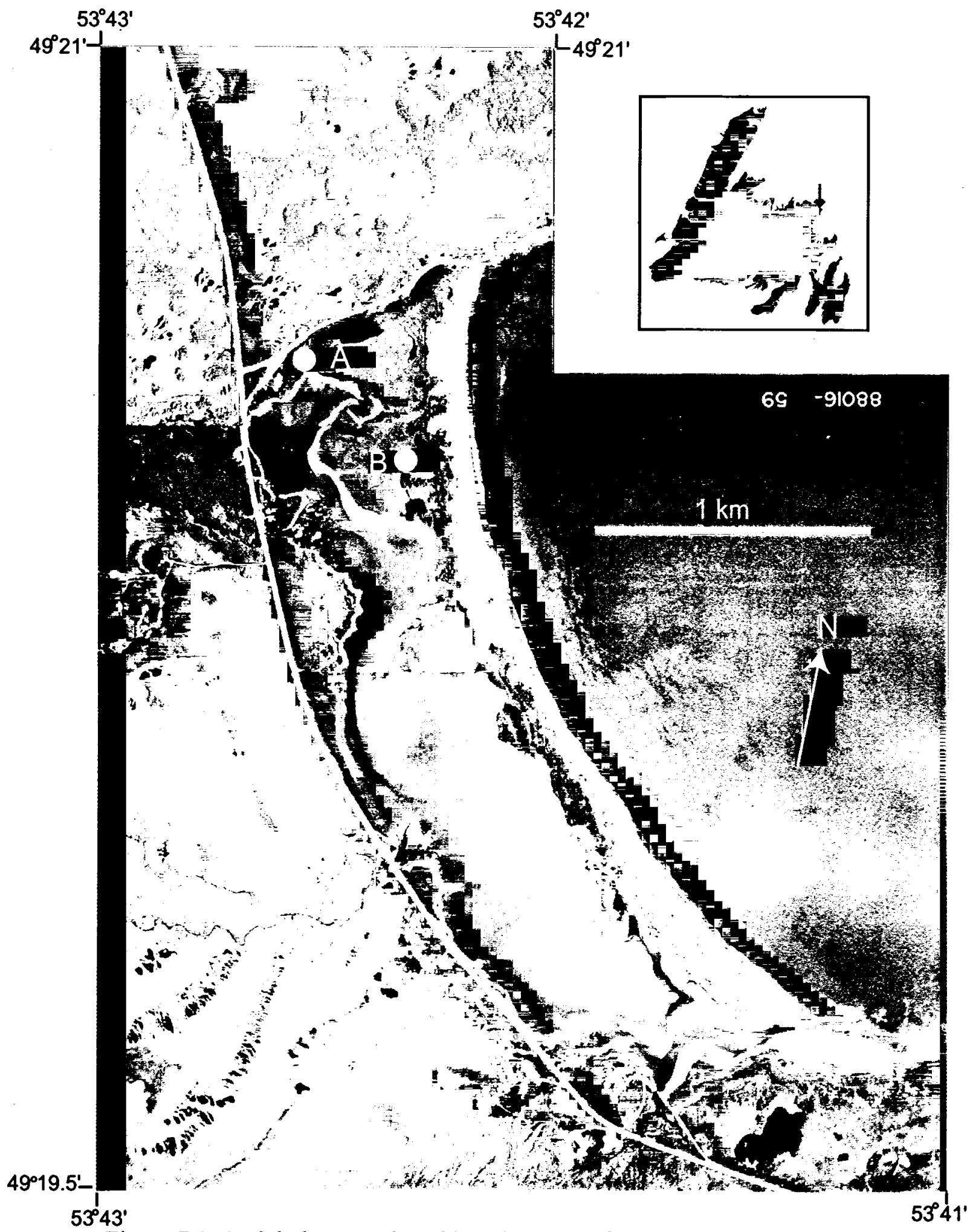

Figure 7.1 Aerial photograph and location map of Deadman's Bay barrier. Location of core transects is indicated. 


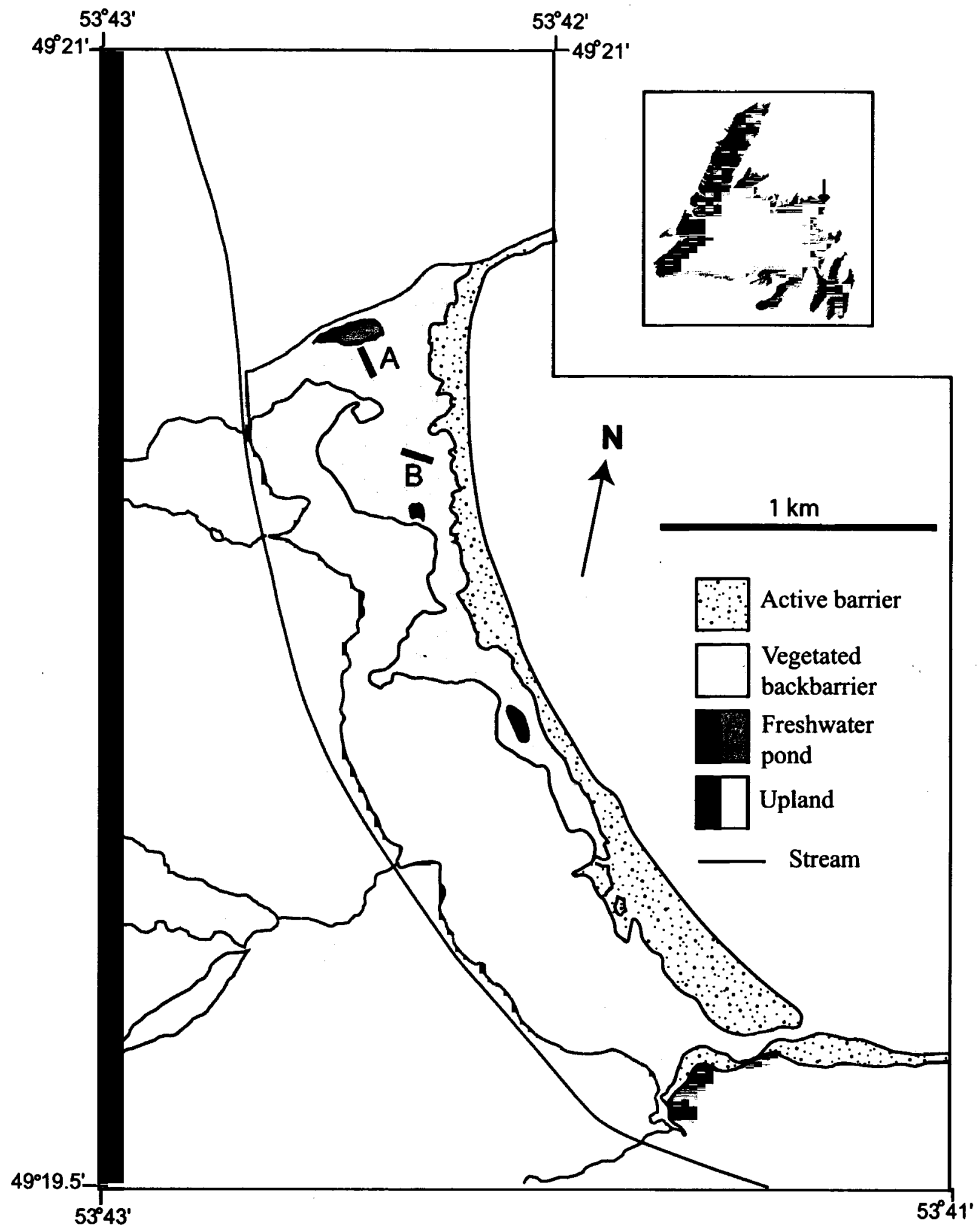

Figure 7.2 Geomorphic map of Deadman's Bay barrier. Location of core transects is indicated. 


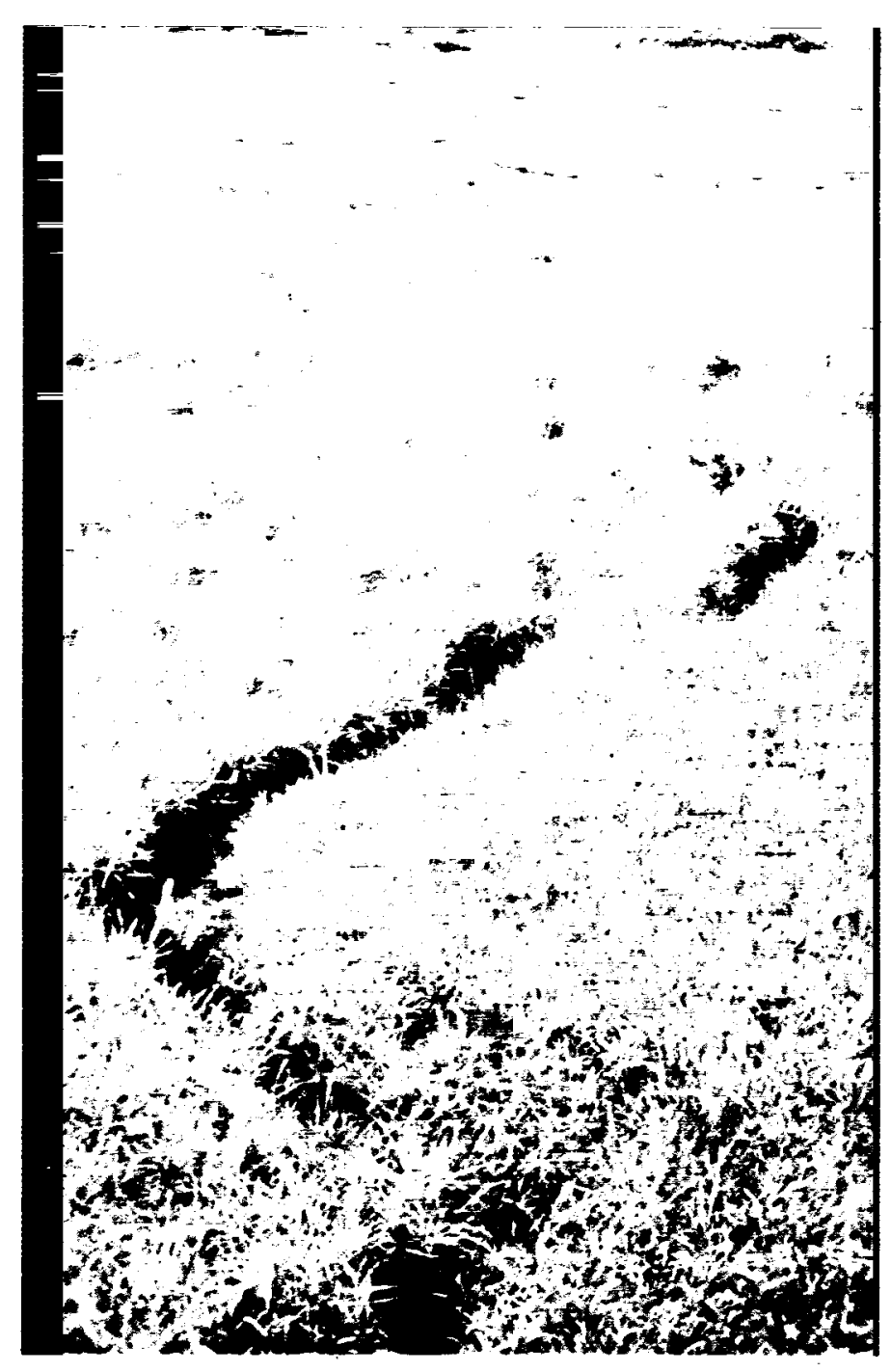

Figure 7.3 Close-up view or marsh surface looking east, near transect 1. Cracks in the surface may be the result of solifluction and may leave gaps of several centimeters in the marsh surface. 

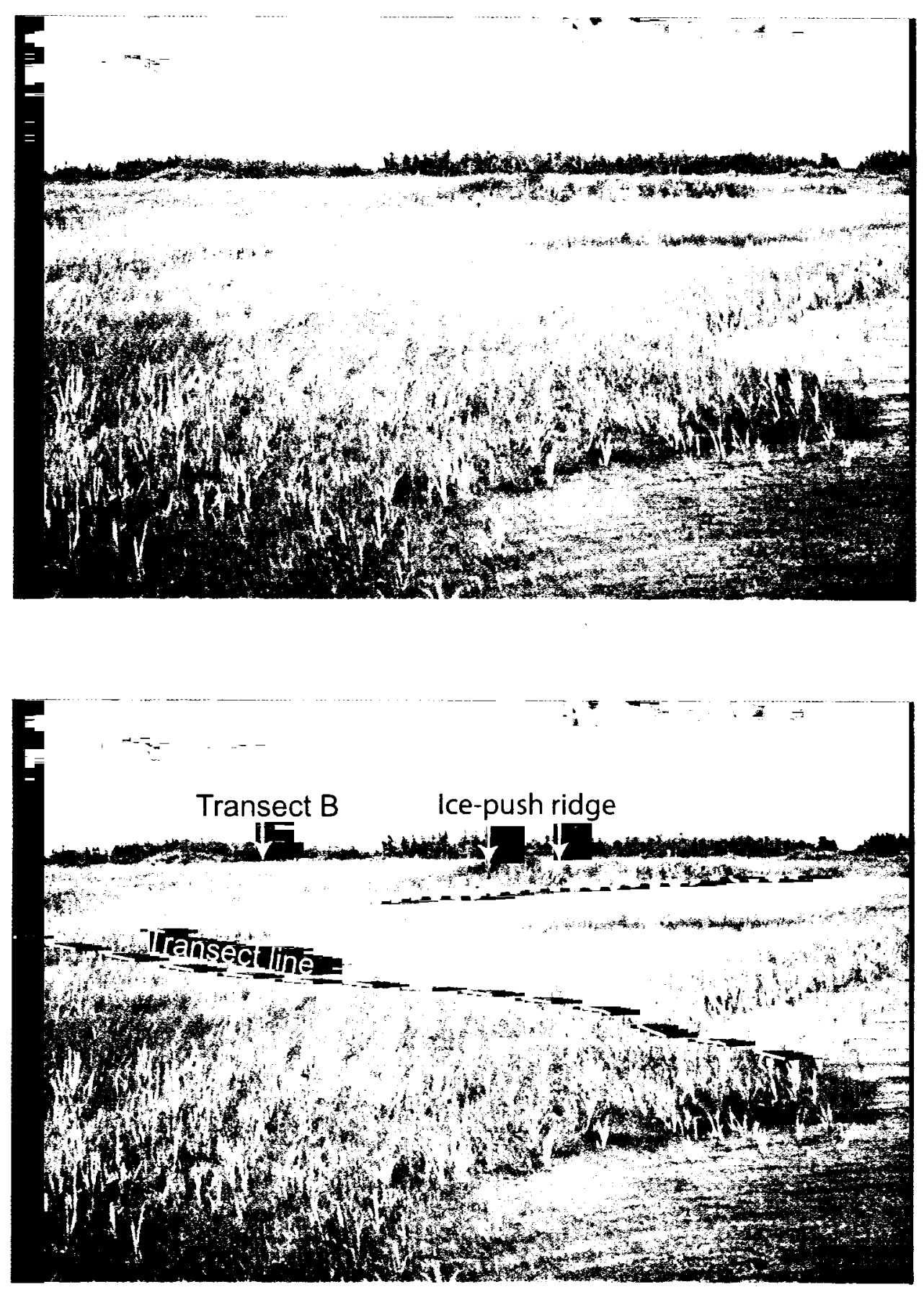

Figure 7.4 Southern surface sample transect at Deadman's Bay, view to the east. Ice-push ridges are distinguished by topotgraphy and vegetation. Note Scirpus sp. growing to water's edge along transect, indicating brackish conditions. Location of transect B is in the distant background. 
Service, 1999). Periodic water-level measurements over a tidal cycle at the northwestern end of the barrier reveal that the tidal range is greatly truncated behind the barrier (Table 7.1). Several streams may provide significant freshwater to the lagoon (Figure 7.2).

Table 7.1 Tidal range projections for Valleyfield and Deadman's Bay.

\begin{tabular}{lll}
\hline & & Location \\
\hline Mean tidal range & $0.67 \mathrm{~m}$ & Valleyfield \\
Spring tidal range & $0.88 \mathrm{~m}$ & Valleyfield \\
Projected tidal range 7-20-99 & $0.45 \mathrm{~m}$ & Valleyfield \\
Measured tidal range 7-20-99 & $0.08 \mathrm{~m}$ & Deadman's Bay \\
\hline
\end{tabular}

The present backbarrier flora is not that of a typical salt marsh. The surface is dominated by Scirpus and Carex species; Juncus gerardii is present in some areas. No foraminifera were found in surface samples collected along two transects. Scirpus growing to the water's edge confirms the brackish nature of the backbarrier (Figure 7.4). The foraminiferal zones of basal samples at this location are based on samples collected at Village Cove, New World Island, approximately $75 \mathrm{~km}$ west of Deadman's Bay. The foraminiferal zones are defined primarily by the relative abundances of $B$.

pseudmacrescens versus $J$. macrescens. Samples with more abundant $J$. macrescens are associated with a higher elevation range, and characterize the higher high marsh. A complete description of the surficial zonation at Village Cove is included in Chapter 4 .

Table 7.2 Foraminiferal zones at Village Cove, New World Island.

\begin{tabular}{llll}
\hline Zone & Range $(\mathrm{m})$ & Flora & Foraminifera \\
\hline High marsh & $0-0.17$ & Mixed & $\begin{array}{l}\text { B. pseudomacrescens, } \\
\text { J. macrescens }\end{array}$ \\
Higher high marsh & $0.17-0.32$ & $\begin{array}{l}\text { D. spicata, } S . \\
\text { patens }\end{array}$ & $\begin{array}{l}\text { J. macrescens, } B . \\
\text { pseudomacrescens }\end{array}$ \\
\hline
\end{tabular}




\section{Previous Work}

Recent sea-level trends have been inferred from isolated cores collected at several barriers in the vicinity of Deadman's Bay (Shaw and Forbes, 1990; Shaw and Edwards, 1994). Previous work at Deadman's Bay included analysis and interpretation of two cores collected at the northwest end of the barrier (Shaw and Forbes, 1990). Basal sediments were analyzed for foraminifera and found to be barren. Radiocarbon dated salt marsh peat at Man Point, just west of Deadman's Bay, constrains paleo-sea level to -0.15 m asl at $3162 \pm 104 \mathrm{cal}$ yr BP (Shaw and Forbes, 1990). Other dated material only indicates terrestrial versus marine association; these dates are summarized in Table 7.3. Many of the late Holocene dates are on freshwater peat, indicating a maximum elevation for sea level.

More research has focused on early Holocene sea-level changes in this area. Postglacial highstand in this area may be $\sim 45 \mathrm{~m}$ asl (Grant, 1980) or higher (Catto, 1993), but this is not well constrained. There is no good chronological definition of the highstand. An in situ sample of Abies balsamea from Pound Cove, southeast of Deadman's Bay, indicates that sea-level passed below present by $9071 \pm 65 \mathrm{cal}$ yr BP (Shaw and Edwardson, 1994). The lowstand is defined by wave-cut terraces at -17 to $-21 \mathrm{~m}$ asl (Shaw and Edwardson, 1994). By correlation with geophysical data from Hamilton Sound, an in situ Mya truncata dated to $9638 \pm 147$ cal yr BP provides another indication of the timing of the lowstand. 


\section{$\underline{\text { Results }}$}

\section{Salt-marsh Stratigraphy}

There are four main stratigraphic units: sand; organic mud (gyttja); higher-highmarsh peat; and freshwater/transitional peat. The sand unit has a fine-grained, wellsorted texture and is dominantly quartz. The organic mud (gyttja) is an olive-grey ( $5 \mathrm{Y}$ $5 / 2)$ to brown (2.5 Y 4/2) colored mud with some in situ rootlets. This unit was also identified and described by Shaw and Forbes (1990). The peat units are differentiated by floral components and foraminiferal assemblage. The brackish-fresh peat is a fibrous peat associated with Scirpus sp. and barren of foraminifera. The higher high marsh peat is a fibrous peat associated with Juncus roots and abundant J. macrescens.

Cores for detailed analysis were collected along two transects in the proximal backbarrier area, close to the areas selected for single cores by Shaw and Forbes (1990). The stratigraphy interpreted along the two transects differs, reflecting the influence of the flood-tidal channels. Transect A is oriented west-east across the northwestern (proximal) end of the barrier (Figure 7.1). Fine-grained, well-sorted sand is overlain by approximately $0.6-0.7 \mathrm{~m}$ of peat (Figure 7.5 ). The lower $0.2-0.3 \mathrm{~m}$ of peat is HHM peat, grading to brackish-fresh peat. In some areas, the surface was vegetated by bog plants and woody shrubs.

Transect B is oriented oblique to the trend of one of the paleo-flood-tidal channels (Figure 7.6). The basal unit is fine, well-sorted sand incised at the eastern end of the transect and filled with almost one meter of gyttja (Figure 7.7). Overlying this fill, and 


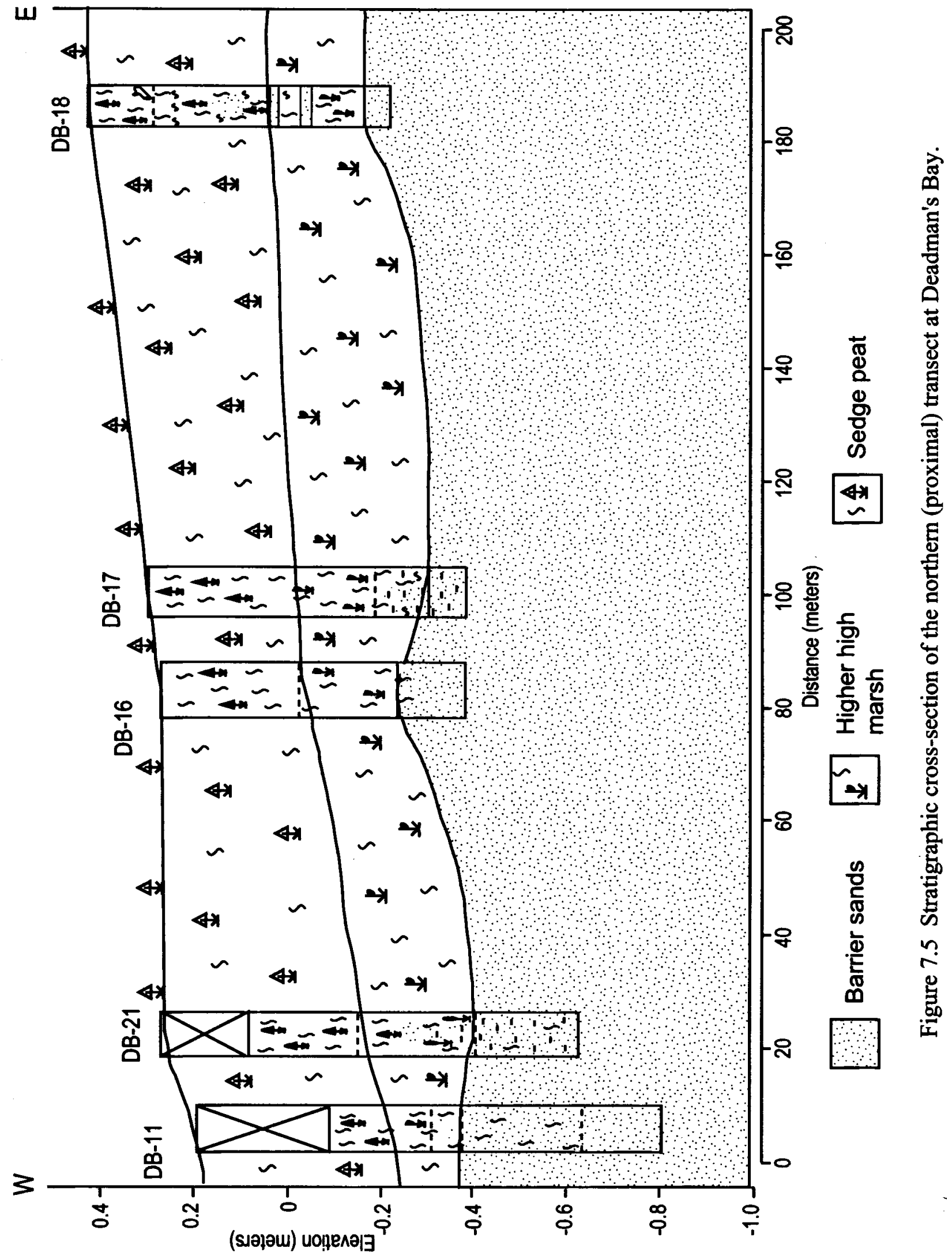




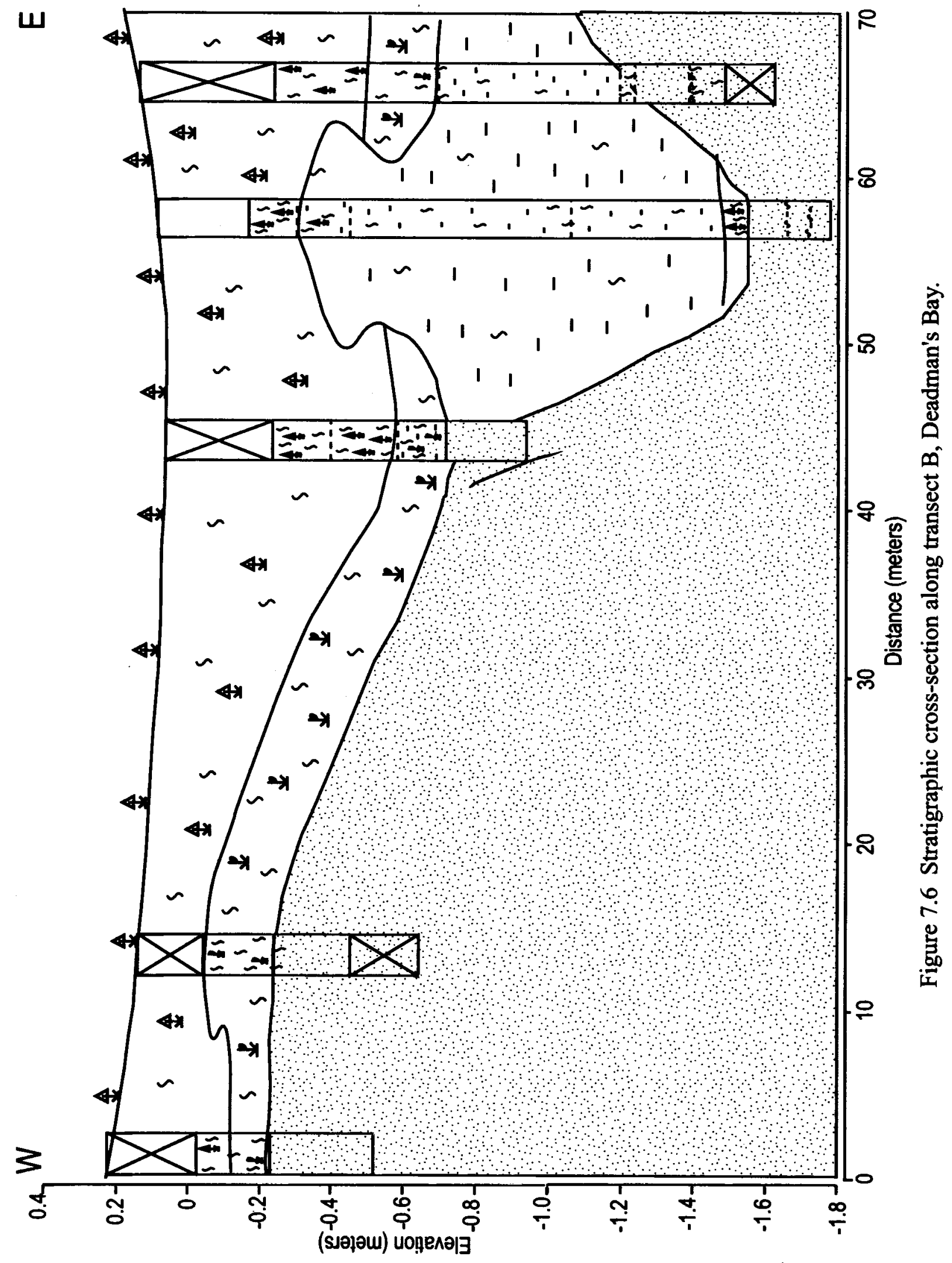


directly overlying the fine sand at the western end of the transect, is a unit of higher high marsh peat approximately $30 \mathrm{~cm}$ thick. This higher high marsh peat grades upward into a brackish-fresh sedge peat that constitutes the present vegetation in the backbarrier.

The stratigraphy of both these transects is regressive. The transition from barrier sands to HHM peat, then to brackish-fresh peat indicates decreasing marine influence at the more confined end of the lagoon. This may be explained by either: 1) a fall in local relative sea level, or 2) isolation from marine influence due to high sedimentation rates. Neither hypothesis is mutually exclusive. The role of local sea-level change is addressed in the following section. On the basis of the stratigraphy and field observations, it is likely that southward progradation of the spit led to restriction of the tidal inlet and decreased open-marine exchange with the lagoon. The numerous freshwater streams flowing into the lagoon may have reduced the salinity of the water and promoted the expansion of brackish and freshwater flora.

\section{$\underline{\text { AMS }}{ }^{14} \mathrm{C}$ Dates}

Four new $\mathrm{AMS}{ }^{14} \mathrm{C}$ dates were obtained from basal peat samples at Deadman's Bay. A complete description of these results is included in Appendix II. The sampled sites are indicated on the transect cross-sections, and results are summarized in Table 7.3. All of the samples were detrital grass fragments, mostly Scirpus. Calibrated ages range from $181 \pm 44 \mathrm{yr}$ BP to $1561 \pm 49 \mathrm{yr}$ BP. The three older samples are associated with salt marsh; the youngest sample is from the greatest depth and is associated with deposition in one of the freshwater ponds in the back-barrier. This sample, DB-19-95, is not directly associated with sea level, and is not considered to be a good index point. The 


\begin{tabular}{|c|c|c|c|c|c|}
\hline Location & Lab ID & Sample ID/description & Age cal yr BP & $\begin{array}{l}\text { Elevation } \\
\text { (meters) }\end{array}$ & Source \\
\hline Man Point & GSC-4604 & Fresh peat & $179.5 \pm 35.5$ & 2.4 & NA Shaw and Forbes, 1990 \\
\hline Deadmans & BET-27234 & Fresh peat & $1218 \pm 50$ & 0.67 & NA Shaw and Forbes, 1990 \\
\hline Cape Freel & GSC-4542 & Fresh peat & $1537 \pm 30$ & 4.71 & NA Shaw and Forbes, 1990 \\
\hline Deadmans & BET-27233 & Gyttja & $1644.5 \pm 34.5$ & -0.56 & NA Shaw and Forbes, 1990 \\
\hline Man Point & BET-36169 & Fresh peat & $2222 \pm 44$ & 0.85 & NA Shaw and Edwards, 1994 \\
\hline Man Point & GSC-4509 & Fresh peat & $2825.5 \pm 50.5$ & 1.1 & NA Shaw and Forbes, 1990 \\
\hline Man Point & GSC-4592 & Salt-marsh peat & $3162 \pm 104$ & -0.15 & 0.3 Shaw and Forbes, 1990 \\
\hline Man Point & GSC-4662 & Fresh peat & $3262 \pm 102$ & -0.1 & NA Shaw and Forbes, 1990 \\
\hline Man Point & GSC-4520 & Fresh peat & $3392.5 \pm 76.5$ & 1.14 & NA Shaw and Forbes, 1990 \\
\hline Eastport & BET-27231 & Fresh peat & $6290 \pm 119$ & -3.3 & NA Shaw and Forbes, 1990 \\
\hline Pound & GSC-4882 & Wood & $9071 \pm 65$ & 0 & NA Shaw and Edwards, 1994 \\
\hline Hamilton & BET-51675 & Shell & $9637.5 \pm 148.5$ & -55.4 & 1 Shaw and Edwards, 1994 \\
\hline Hamilton & BET-51676 & Bryozoan & $10470.5 \pm 112.5$ & -55.5 & 1 Shaw and Edwards, 1994 \\
\hline Newtown & WAT-888 & Wood & $12091.5 \pm 541.5$ & 0 & NA Davis and Wickham, 1987 \\
\hline Freemans & GSC-3973 & Gyttja & $13008.5 \pm 196.5$ & 56 & NA Blake, 1987 \\
\hline Parsons & GSC-4182 & Shell & $13919 \pm 415$ & 2 & 1 Shaw and Forbes, 1990 \\
\hline Hamilton & BET-51677 & Shell & $13566 \pm 119$ & -56.6 & 1 Shaw and Edwards, 1994 \\
\hline Exploits & BET-51672 & Shell & $13984 \pm 160$ & -82 & 1 Shaw and Edwards, 1994 \\
\hline Deadman's & DB-12-36 & & $193 \pm 25$ & -0.223 & This study \\
\hline Deadman's & DB-19-95 & & $181 \pm 44$ & -0.677 & This study \\
\hline Deadman's & DB-16-50 & & $1219 \pm 21$ & -0.225 & This study \\
\hline Deadman's & DB-18-58 & & $1560.5 \pm 49.5$ & -0.146 & This study \\
\hline
\end{tabular}

Table 7.3 Radiocarbon data for northeastern Newfoundland from this and published studies. 
samples are all from a very narrow depth range, between -0.25 to $-0.68 \mathrm{~m}$. The wide range in ages across a narrow elevation range is consistent with the range of ages that might be expected based on previous studies.

\section{Discussion}

This study provides important definition of late Holocene sea-level change in this area; previous studies only inferred sea-level change during this period by dating freshwater deposits close to sea level (Shaw and Forbes, 1990; Shaw and Edwardson, 1994). The four new dates acquired for this study indicate that sea-level has remained nearly constant from $\sim 1500$ yr BP to present (Figure 7.7). The salt marsh peat (GSC4592) dated by Shaw and Forbes (1990) is associated with a different datum, but by applying very conservative (large) vertical error bars, this index point is included in the envelope of sea-level change (Figure 7.7). Inclusion of this point extends the late Holocene record to $\sim 3100 \mathrm{yr} \mathrm{BP}$, and indicates that sea level has remained close to present since that time. The depth of these index points suggests that sea-level may have risen in the past 200 years, but no data are available to address this hypothesis.

The development of the Deadman's Bay barrier may reflect the consistent late Holocene sea level. The sea-level history at this location does not support local relative sea-level fall, and the regressive stratigraphy observed at this location must be explained by abundant sediment supply. Following initial deposition of the barrier and associated flood-tidal delta, a salt marsh was established. As the barrier-spit prograded to the southeast, marine influence in the lagoon declined and brackish and freshwater flora and fauna became dominant. 


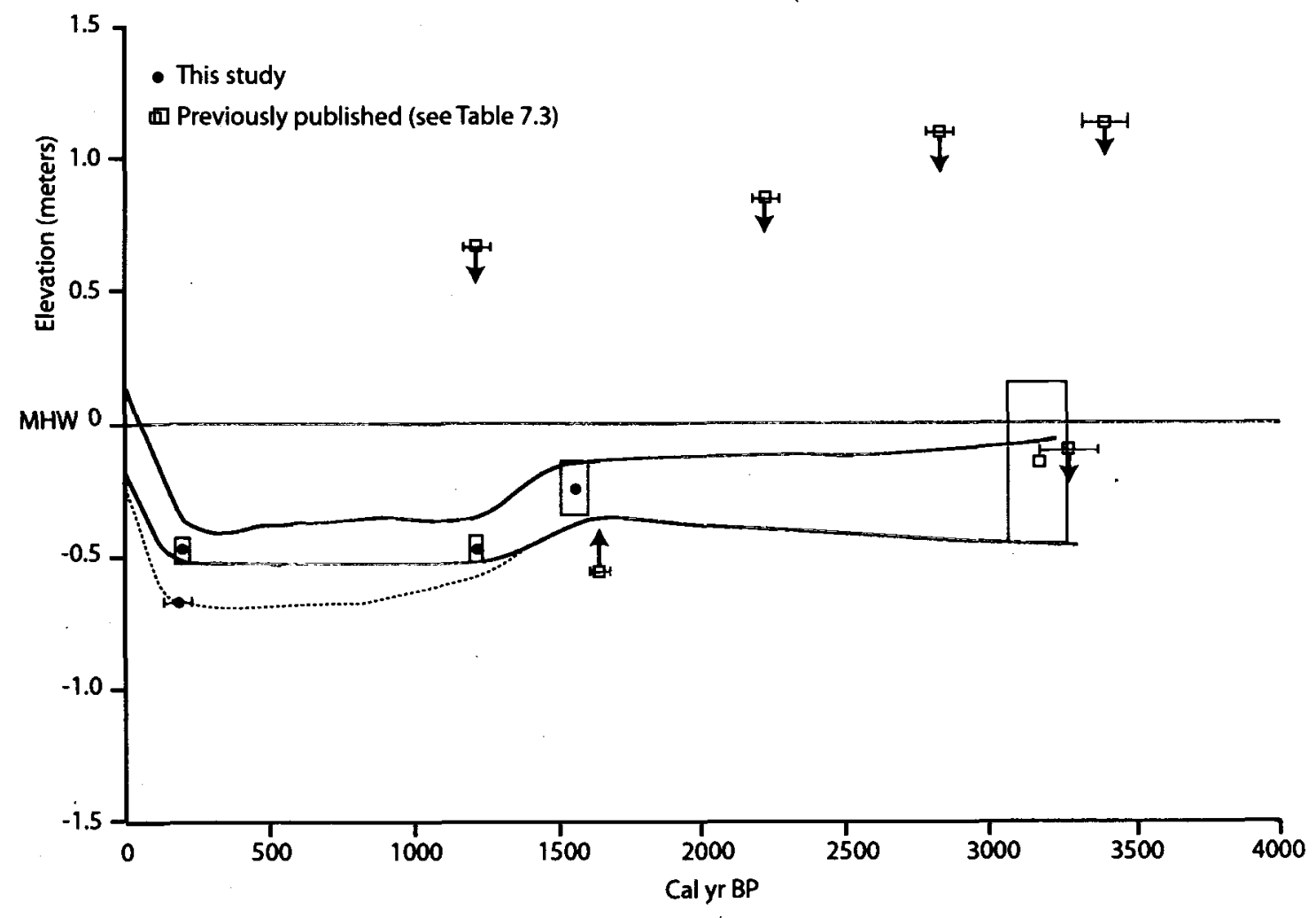

Figure 7.7 Late Holocene relative sea-level change reconstruction for Deadman's Bay. Arrows from index points indicate the sea level was above or below point. 


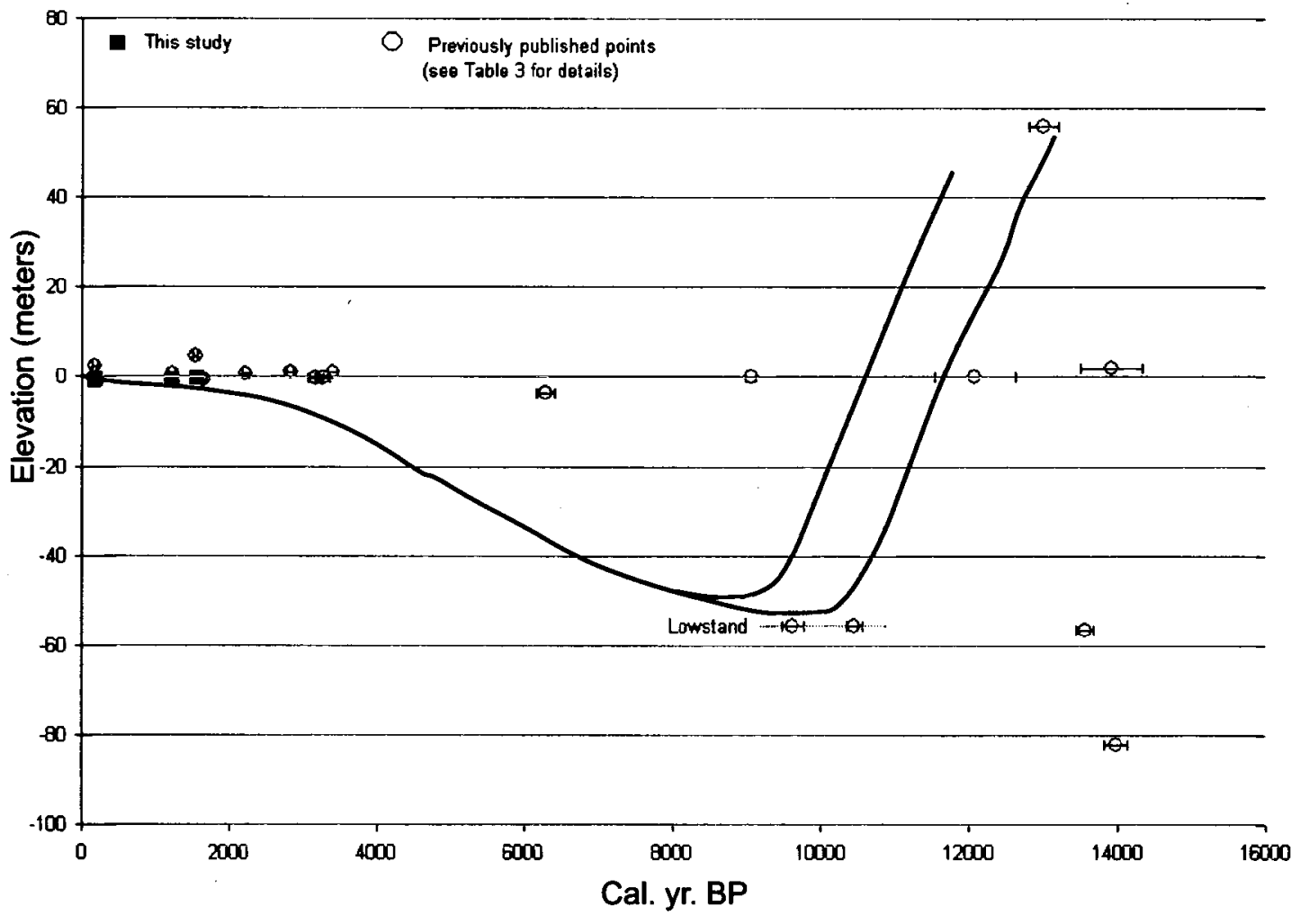

Figure 7.8 Late Pleistocene - Holocene sea-level change reconstruction for northeast Newfoundland. 
The chronology of late Pleistocene to early Holocene sea-level change is altered by calibrating ${ }^{14} \mathrm{C}$ dates. Previous research based sea-level changes during this period on ages reported in ${ }^{14} \mathrm{C}$ yr BP. The calibration of these published dates yields older ages for many early Holocene samples. A wood sample at $\sim 0$ m asl (WAT-888) was previously reported as $10,290 \pm 380{ }^{14} \mathrm{C}$ yr BP (Davis and Wickham, 1987); the calibrated age is $12092 \pm 541{ }^{14} \mathrm{C}$ yr BP. The shape of the late Pleistocene - Holocene sea-level change curve for this area is a type B, but better definition of the early and mid-Holocene sealevel history is needed (Figure 7.8). 


\section{Chapter 8}

\section{PLACENTIA, AVALON PENINSULA}

\section{Introduction and Geologic Setting}

Placentia is located at $47^{\circ} 14^{\prime} \mathrm{N}$ and $57^{\circ} 58^{\prime} \mathrm{W}$ on the western coast of the Avalon Peninsula in the southeastern part of Newfoundland (Figure 8.1). Salt marshes are not abundant on the Avalon peninsula, despite an abundance of baymouth barriers that provide significant shelter. Some of the backbarrier areas are vegetated, but the peat is typically thin and the flora represents brackish or upland environments. It is possible that significant freshwater discharge into the lagoons from rivers and streams inhibits the development of salt marshes in many areas.

The salt marsh investigated at Placentia overlies the lee side of a complex swashaligned barrier-spit. A dozen phases, or pulses, of progradation identified by Shaw and Forbes (1990) compose the barrier. Interpretation of aerial photographs shows an initial phase of recurved spits followed by successive progradation seaward (Figure 8.2). Early phases of the barrier were bounded on either end by outcropping bedrock. Additional sediment allowed progradation of the barrier seaward of the distal bedrock headland and redevelopment of a spit. An early eighteenth century map of the area shows a barrier configuration similar to the present, and notes the gravel beach where cod were dried on the seaward side of the barrier (Fig. 8.3). Much of the barrier was protected by engineered structures during re-settlement efforts post-1950, as seen by comparing aerial photos from 1950 and 1995 (Figures 8.1, 8.4). 


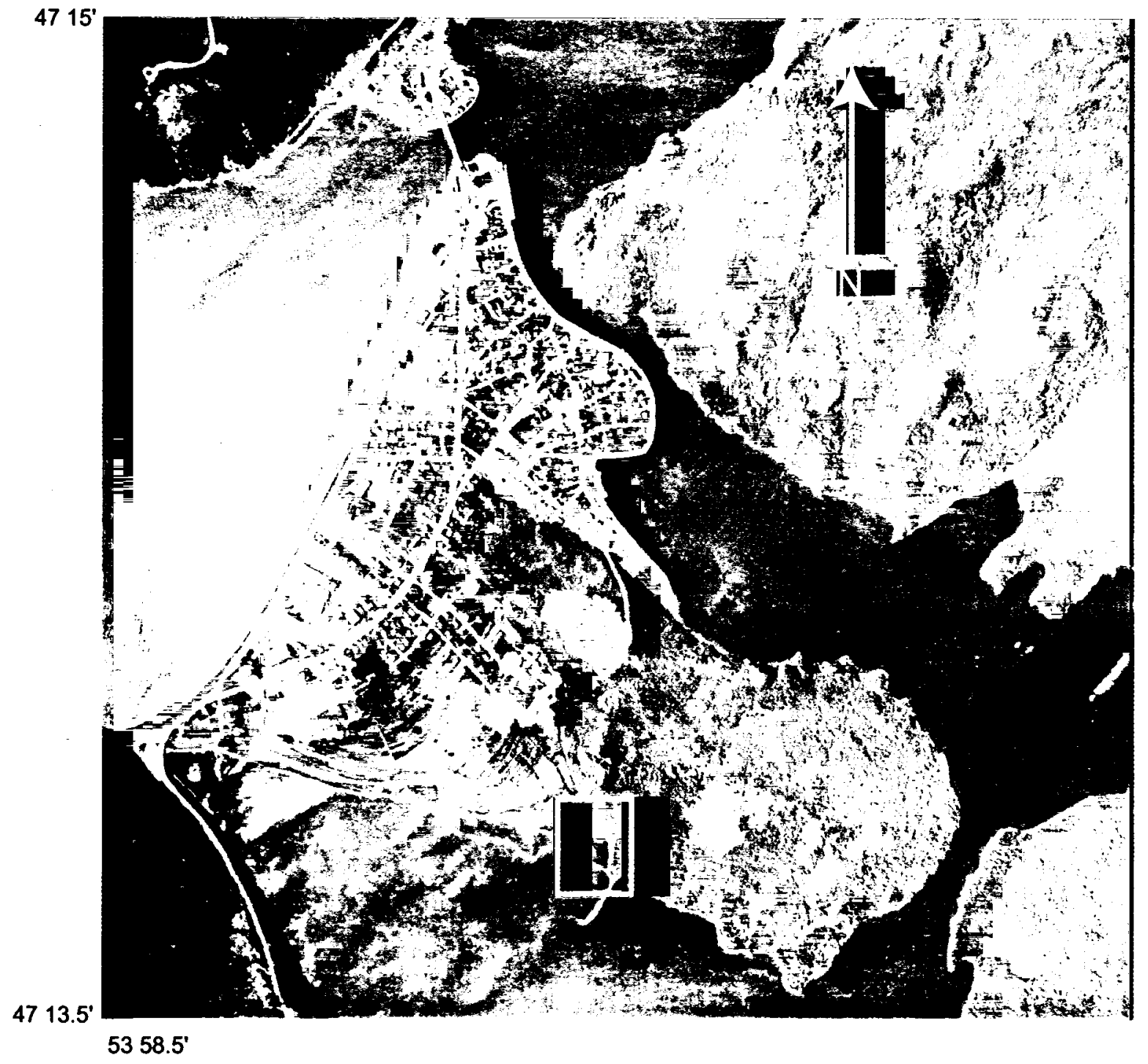

Figure 8.1 Location of field area in Southeast Arm, Placentia. Aerial photograph of Placentia, 1993. The field site is shown by the white square. 


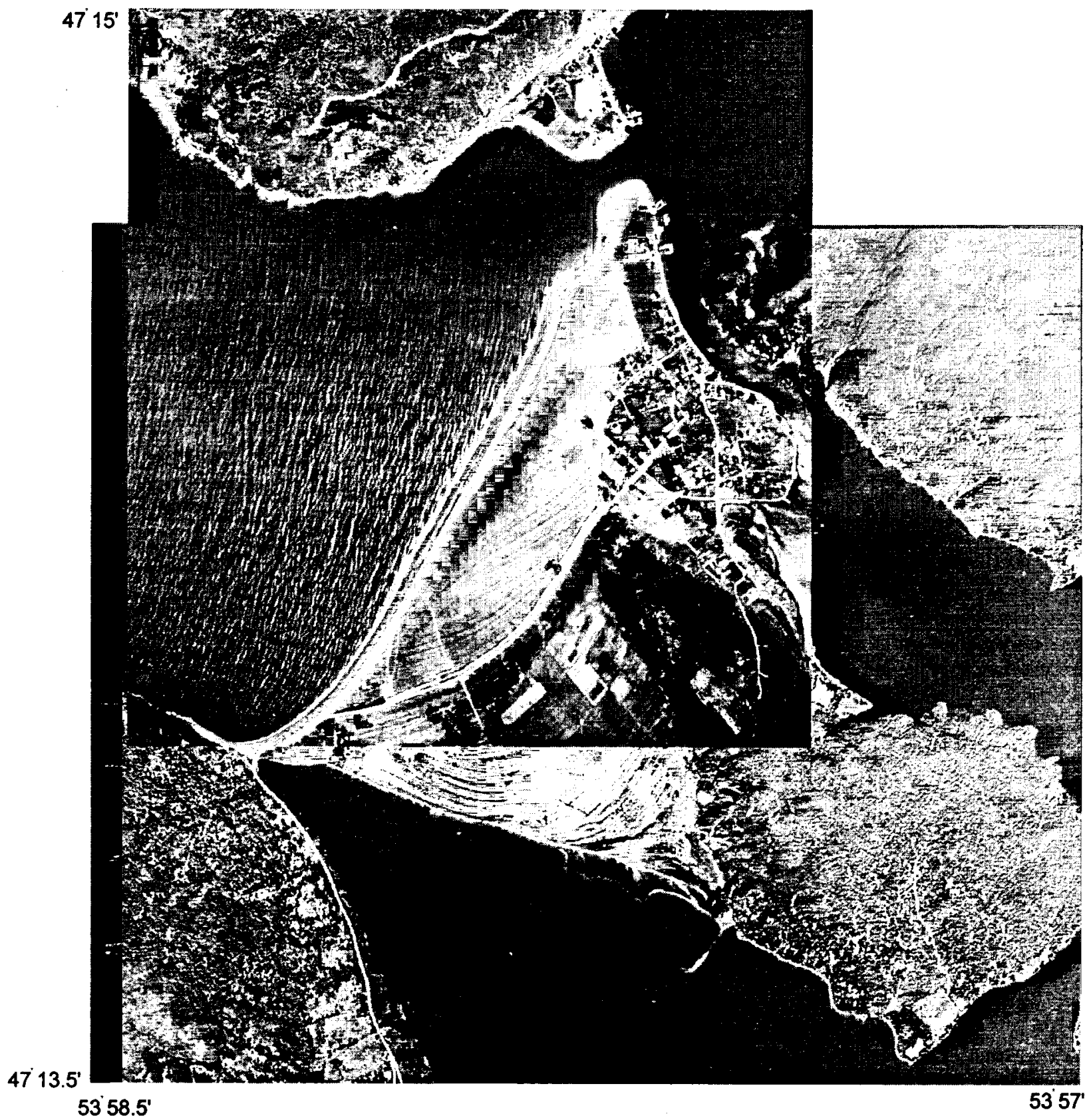

Figure 8.2 Aerial photographs of Placentia c. 1950, prior to re-settlement of many people from outports. Note the completely undeveloped beach plain. 
•วu!̣ s!

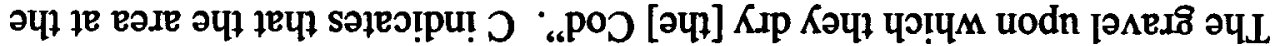

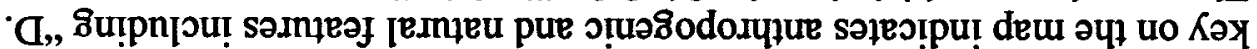
әપI pure ' '

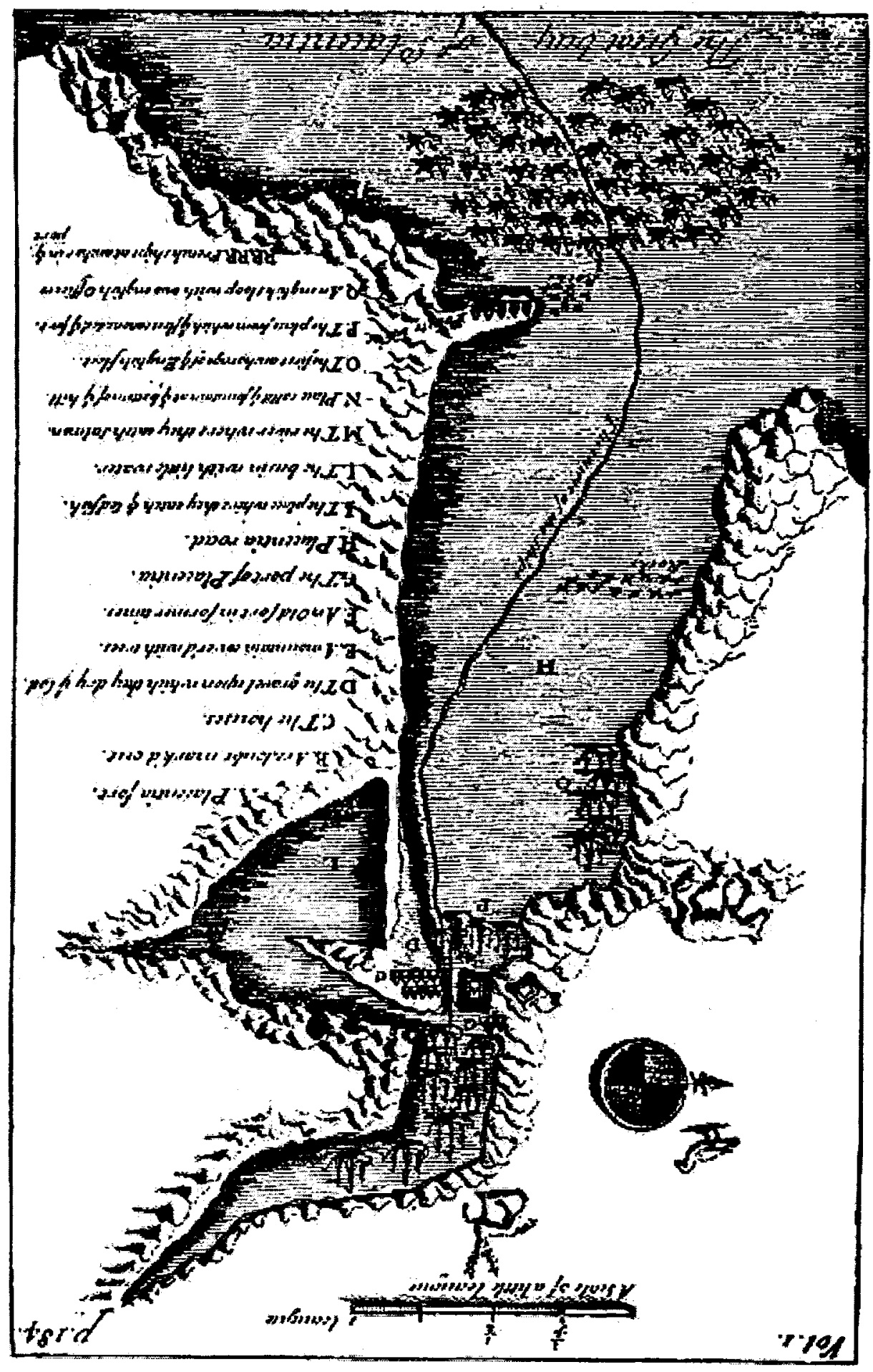




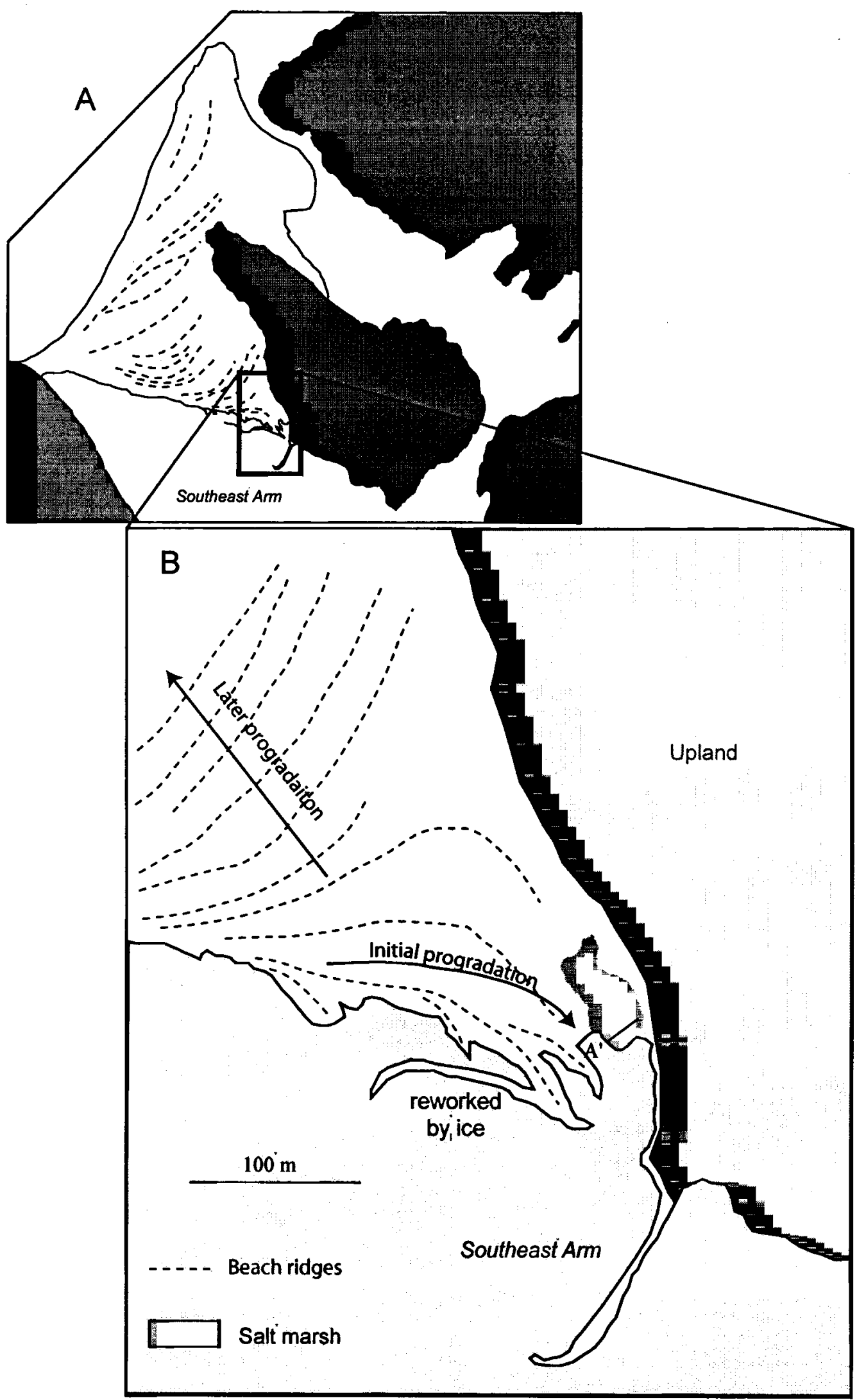

Figure 8.4 Generalized geomorphic maps of A) Placentia and B) the field site. 
Tidal ranges at Placentia are estimated from Argentia, $\sim 5 \mathrm{~km}$ north-northwest (Canadian Hydrographic Service, 1999). These ranges are most accurate for the western side of the barrier complex, open to Placentia Bay. Marine access to the backbarrier area, the Southeast Arm, is extremely restricted at this location. Water is forced to pass through two narrow openings: 1) at the northern end of the barrier, an engineering structure fixes the channel; 2) at the eastern end of the bedrock knob bounding the barrier, the water must pass through a bedrock-controlled bottleneck. These two restrictions may explain why the tidal range in the back barrier area is significantly decreased (Table 8.1). Measurements in the field also indicated a $\sim 0.5$ hour lag from predicted high tide at Argentia at the field site.

Table 8.1 Projected tidal ranges at Argentia and measured range at Placentia (Canadian Hydrographic Service, 1999).

\begin{tabular}{lcl} 
& Range (meters) & \multicolumn{1}{c}{ Location } \\
\cline { 2 - 3 } Mean tidal range & 1.49 & Argentia \\
Spring tidal range & 1.92 & Argentia \\
Projected tidal range 7-28-99 & 1.4 & Argentia \\
Measured tidal range 7-28-99 & 0.75 & Southeast Arm, Placentia \\
\hline
\end{tabular}

Although the backbarrier area at this location is extensively vegetated, the peat is mostly thin $(<0.50 \mathrm{~m})$. It is locally thick at the eastern end of the barrier adjacent to the steep bedrock outcrop. In this area the vegetation is well zoned (Figure 8.5). The location of the transect in this area is shown in Figure 8.2). There are four main stratigraphic units: fine, well-sorted sand; detrital freshwater peat; higher high marsh peat; and high marsh peat (Figure 8.6). The floral and foraminiferal zones roughly correspond, and are narrowly vertically restricted (Table 8.2). The high marsh (HM) zone, characterized by Spartina patens and an foraminiferal assemblage dominated by equal proportions of $J$. macrescens and B. pseudomacrescens with some $M$. fusca, has a 

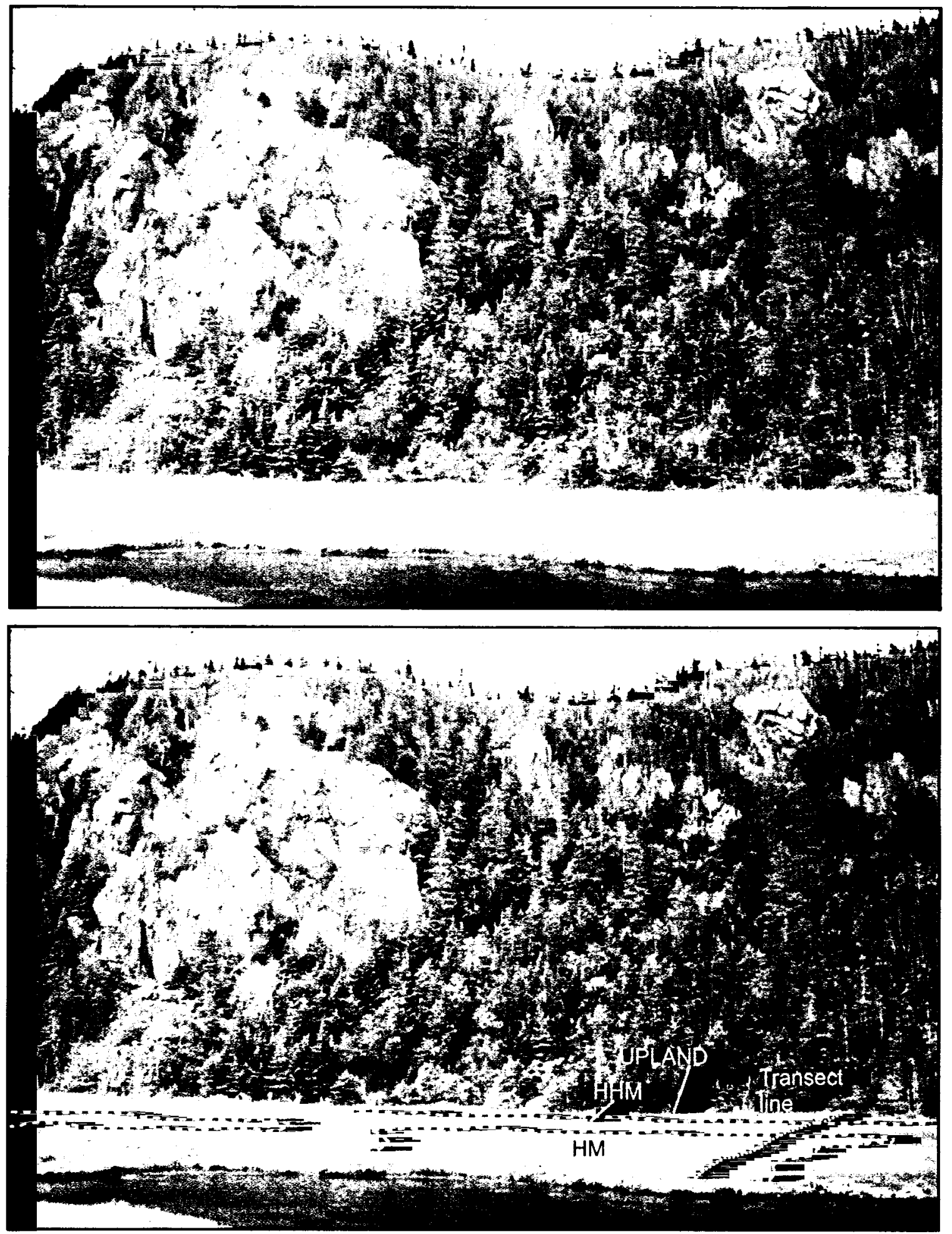

Figure 8.5 Oblique photograph of field area indicating major floral zones and the transect line. 


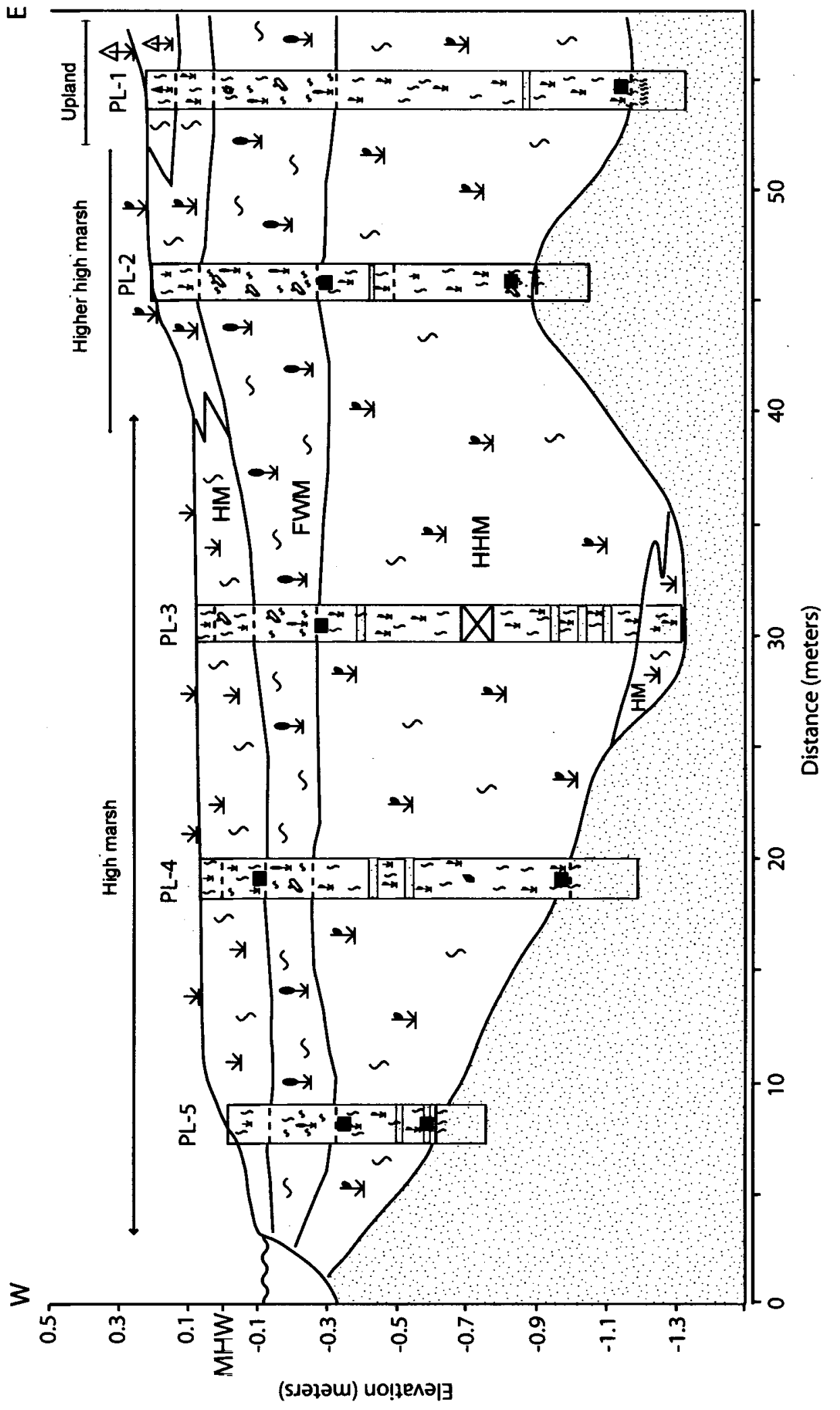

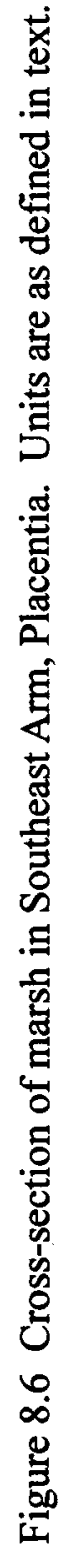


$\sim 0.15 \mathrm{~m}$ vertical range. HM peat is very fibrous, and has little if any inorganic content. The higher high marsh (HHM) zone has a vertical range of $\sim 0.10 \mathrm{~m}$, and is characterized by Juncus gerardii and abundant $J$. macrescens. Freshwater peat is detrital, very dark brown to black in color, and is not associated with any foraminifera. At the high end of the marsh, a narrow transitional zone between the HHM and upland is associated with a mix of Juncus, Potentilla, and unidentified upland grasses.

Table 8.2 Floral and foraminiferal zones at Southeast Arm, Placentia

\begin{tabular}{llll}
\hline Elevation $(\mathrm{m})$ & Zone & Flora & Dominant Foraminifera \\
\hline $0(\mathrm{MHW})-$ & High marsh & Spartina patens & $\begin{array}{l}\text { J. macrescens } \\
\text { B. pseudomacrescens }\end{array}$ \\
0.15 & Higher high marsh & Juncus gerardii & $\begin{array}{l}\text { M. fusca } \\
\text { J. macrescens }\end{array}$ \\
$0.15-0.25$ & Scirpus sp. & \\
\hline 0.25 & Transition & S &
\end{tabular}

\section{Previous Work}

There has been no previous detailed work on the salt marsh at this location or on other salt marshes on the Avalon Peninsula. According to the prediction made by numerical models, this area should have a type B sea-level curve, and may lie just west of a type $\mathrm{C}$ area (Quinlan and Beaumont, 1981). Prior to beginning fieldwork, I anticipated that this area should yield the peat of greatest thickness, based on the numerical models. The barrier at Placentia was investigated by Shaw and Forbes (1995). They determined that the minimum age for the barrier is $\sim 2000{ }^{14} \mathrm{C}$ yr old, as indicated by basal peat (Shaw and Forbes, 1995). The depth of that sample cannot be related to the datum established in this study. 


\section{$\underline{\text { Results }}$}

\section{Salt-marsh Stratigraphy}

Preliminary cores were collected along two northeast - southwest trending transects perpendicular to a small tidal channel incising the marsh. The stratigraphy interpreted along the two transects was similar, and cores for foraminiferal analysis and AMS dating were collected along just one transect (Figure 8.2, 8.5). There are four main stratigraphic units: fine, well-sorted sand; detrital freshwater peat; higher high marsh peat; and high marsh peat (Figure 8.6). A thick (as much as $0.9 \mathrm{~m}$ ) unit of HHM peat overlies the basal fine-grained, well-sorted sand. Unconformably overlying this HHM peat is a $\sim 0.3 \mathrm{~m}$ thick unit of detrital freshwater peat. The uppermost unit is a thin HM peat laterally grading into HHM peat conformably overlying the detrital freshwater peat unit. Scattered lenses of medium-fine-grained sand are found throughout the section.

The salt-marsh stratigraphy at this location may be generally characterized as transgressive. The massive, fine-grained quartz sand is interpreted to be barrier sand deposited during the initial recurved spit stage of the barrier. The thick HHM peat is interpreted to represent a period of transgression during which the barrier was initially colonized by marsh flora and fauna, and the sedimentation on the marsh surface kept pace with rising MHW. The abrupt change to detrital, freshwater peat across the marsh may be interpreted as either: 1) a regression and stasis or drop in local relative sea level, or 2) closure of the local barrier inlet (or one of the inlets to the Southeast Arm) and a period of no marine influence. Subsequent conformable development of a HM and HHM peat above this freshwater unit indicates recent local relative sea-level rise or breaching 
of one of the bottlenecks. Lenses (up to $1 \mathrm{~cm}$ thick) of fine-grained sand could not be correlated to each other, and are interpreted to be ice-rafted debris.

\section{$\underline{\text { AMS }{ }^{14} \mathrm{C} \text { Dates }}$}

A complete report of the data associated with these radiocarbon dates and calibrations is included in Appendix C. Eight AMS ${ }^{14} \mathrm{C}$ dates from five cores constrain the age of stratigraphic units and boundaries at this location. Four of the dates are for basal samples; four dates are in-core samples. Samples are indicated on the stratigraphic cross-section (Figure 8.6). Basal dates ranged from $\sim 2100$ cal yr BP to $\sim 1376$ cal yr BP; age increased as depth in core increased. All of these dates are considered viable for interpretation of of past sea level.

Three in-core dates were obtained from samples at the base of the freshwater peat unit. Ages of these three samples ranged from $\sim 708 \mathrm{cal} \mathrm{yr}$ BP to $\sim 189 \mathrm{cal} \mathrm{yr} \mathrm{BP}$. The wide range of ages from the base of this unit may indicate gradual development of the freshwater unit, recycling of older material in the detritus, or contamination by younger material. The remaining in-core date was sampled at the upper contact between the freshwater peat and overlying salt-marsh peat, yielding an age of $\sim 100 \mathrm{cal}$ yr BP. This date is used to help reconstruct past sea-level change at this location. Autocompaction is not considered to be great enough to significantly change the elevation of the sample with respect to its original depositional setting. The date is used to constrain the recent development of salt marsh over detrital peat. 
Table 8.3 Radiocarbon data for Southeast Arm, Placentia.

\begin{tabular}{llllll}
\hline $\begin{array}{l}\text { Sample } \\
\text { type }\end{array}$ & Lab ID & Sample ID & Age (cal yr BP) & Elevation (m) Sample description \\
\hline Basal & T14366 & PL-1-137 & $2101 \pm 58$ & -1.151 & Detrital grass \\
In-core & T14370 & PL-2-49 & $635 \pm 15$ & -0.289 & Detrital grass \\
Basal & T14367 & PL-2-103 & $1469 \pm 62$ & -0.829 & Detrital grass \\
In-core & T14371 & PL-3-35A & $708 \pm 33$ & -0.273 & Detrital grass \\
In-core & T14373A & PL-4-20 & $100 \pm 39$ & -0.137 & Detrital grass \\
Basal & T14372 & PL-4-106 & $1803 \pm 80$ & -0.997 & Detrital grass \\
In-core & T14369 & PL-5-33 & $189 \pm 24$ & -0.349 & Detrital grass \\
Basal & T14368A & PL-5-61 & $1376 \pm 148$ & -0.629 & Detrital grass \\
\hline
\end{tabular}

\section{Discussion}

The salt-marsh stratigraphy and five AMS ${ }^{14} \mathrm{C}$ dates are used to constrain sealevel change at this site. The transgressive marsh stratigraphy is interpreted to reflect long-term sea-level rise. Four basal dates and a shallow in-core date constrain the rate of sea-level rise (Figure 8.7). The oldest basal date of $2101 \pm 58 \mathrm{cal}$ yr BP is consistent with the minimum barrier age estimated by Shaw and Forbes (1990), and suggests that a salt marsh began to develop soon after barrier growth. This and subsequent basal dates indicate slow but consistent sea level rise of $\sim 0.7 \mathrm{~mm} / \mathrm{yr} 1000 \mathrm{cal}$ yr BP. Between 100 and $1000 \mathrm{cal}$ yr BP, no dates are available. The shallow in-core date from PL-4 indicates that salt marsh was re-established at $100 \pm 39 \mathrm{cal}$ yr BP. The tide-gauge trend, based on a linear regression of the data from Argentia, is projected to $500 \mathrm{cal}$ yr BP and plotted with the sea-level index points on Figure 8.7. This trend is similar to the rate of change implied by the single recent index point.

The abrupt, widespread transition to detrital freshwater peat is interpreted to represent a period of either local relative sea-level fall and/or closure of one of the inlets to the Southeast Arm. Based on the in-core radiocarbon dates, this transition occurred prior to $708 \pm 33 \mathrm{cal}$ yr BP, unless that sample is older material that contaminated the 


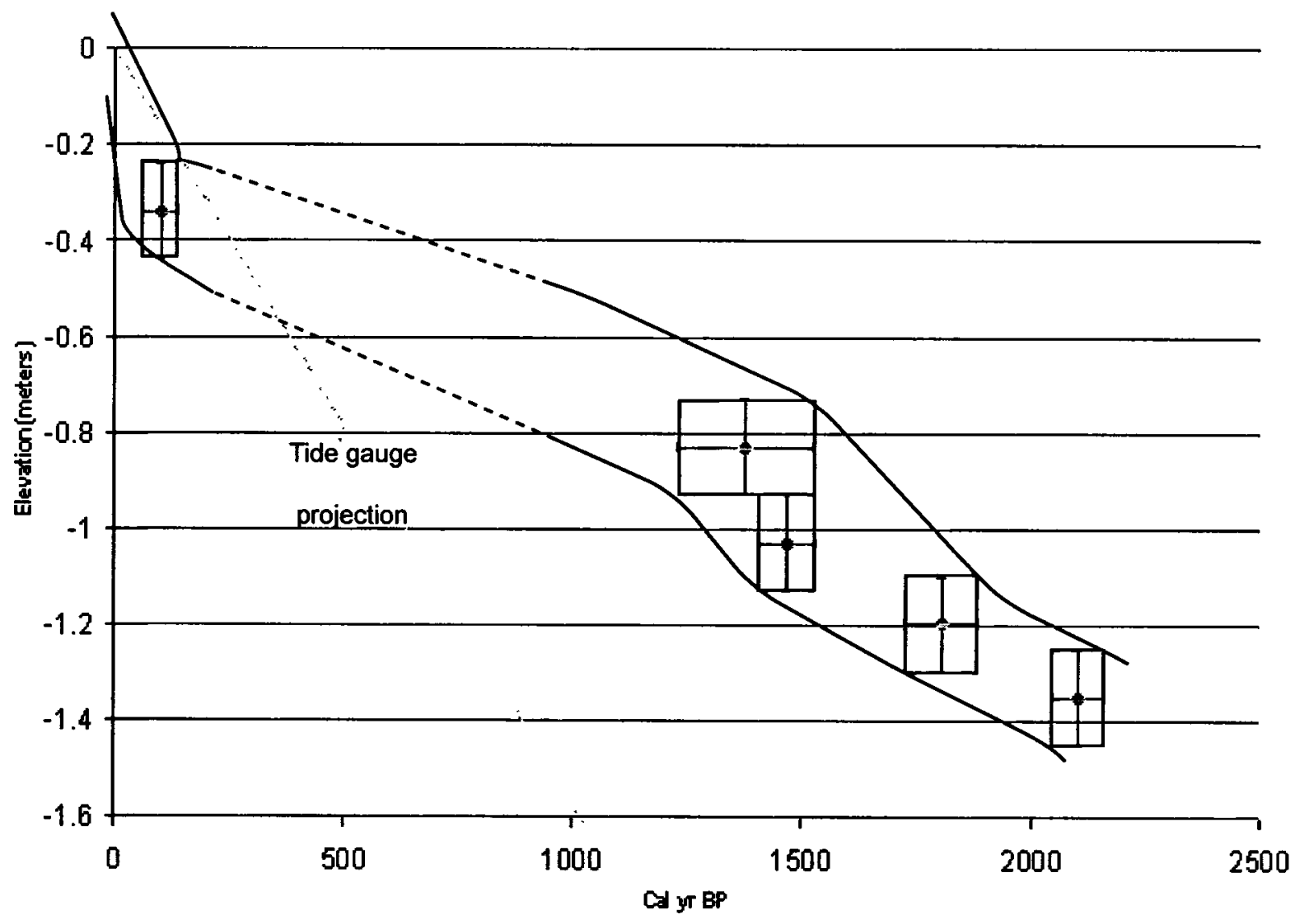

Figure 8.7 Sea level reconstruction for Placentia. Four basal and one in-core radiocarbon dates constrain the rate of rising sea level over the past 2000 years. The dashed line is a projection of the rate of recent sea-level change based on the tide gauge record from Argentia. 
peat. An in-core date from the same elevation in an adjacent core (PL-2) is $635 \pm 15 \mathrm{cal}$ yr BP, supporting the onset of detrital peat deposition prior to $700 \mathrm{cal}$ yr BP. Available data do not help differentiate between the two possible hypotheses for development of this detrital peat. Inlet closure, perhaps even by the small sand and gravel bar immediately south of the field area, is the most plausible explanation for the development of the detrital unit across the entire marsh. It is not possible to determine whether the inlet closure was related to relative sea-level fall. An increase in the sediment flux may have temporarily closed an inlet. The nearshore sand and gravel ridge may have been pushed onshore by ice. It is interesting to note that the onset of the freshwater peat and subsequent re-establishment of salt marsh roughly correspond to the beginning and end of the Little Ice Age (as defined by Mayewski et al., 1993). This cooling may have increased the amount of ice in the backbarrier area of Placentia, leading to the displacement of nearshore sand and gravel bars. Data are not available to consider this idea more than speculation. 


\section{Chapter 9}

\section{LATE HOLOCENE SEA-LEVEL CHANGE AROUND NEWFOUNDLAND}

\section{Introduction}

Late Holocene sea-level change was reconstructed at four sites around Newfoundland using salt-marsh stratigraphy and AMS ${ }^{14} \mathrm{C}$ dating of basal samples (Figure 9.1). These local relative sea-level histories are individually discussed in previous chapters. Each record is related to a local MHW datum, so the records are comparable (Figure 9.2). Comparison reveals that there are significant variations in the trend of sealevel change around the island in the late Holocene. Generally, sea level is rising around the southern part of the island and falling around the northwest of the island. The longest record is from Hynes Brook, on the Port-au-Port peninsula, extending to $\sim 3 \mathrm{kyr}$ BP. The rate of rise from $\sim 3 \mathrm{kyr}$ BP to $\sim 2 \mathrm{kyr} \mathrm{BP}$ is $\sim 2 \mathrm{~mm} / \mathrm{yr}$. This is the most rapid rate of rise among all four records. From 2000 yr BP to the present, the trends at all four sites are slightly different. The rate of rise at each site varies over this period, but in general the fastest rate of rise is still at Hynes Brook. The rate of rise is slightly slower at Placentia and close to $0 \mathrm{~mm} / \mathrm{yr}$ at Deadman's Bay. At St. Paul's Inlet, sea level may have 1) fallen slightly till $1 \mathrm{kyr}$ BP, then risen slightly to present, or 2) slowly fallen continuously to present. The sea-level change envelope for St. Paul's Inlet does not overlap any others (Figure 9.2). The Deadman's Bay envelope overlaps only that of Placentia during the last several hundred years, whereas there is significant overlap between the Placentia and Hynes Brook envelopes. The distinct trends of each reconstruction indicate differential late Holocene sea-level change around 


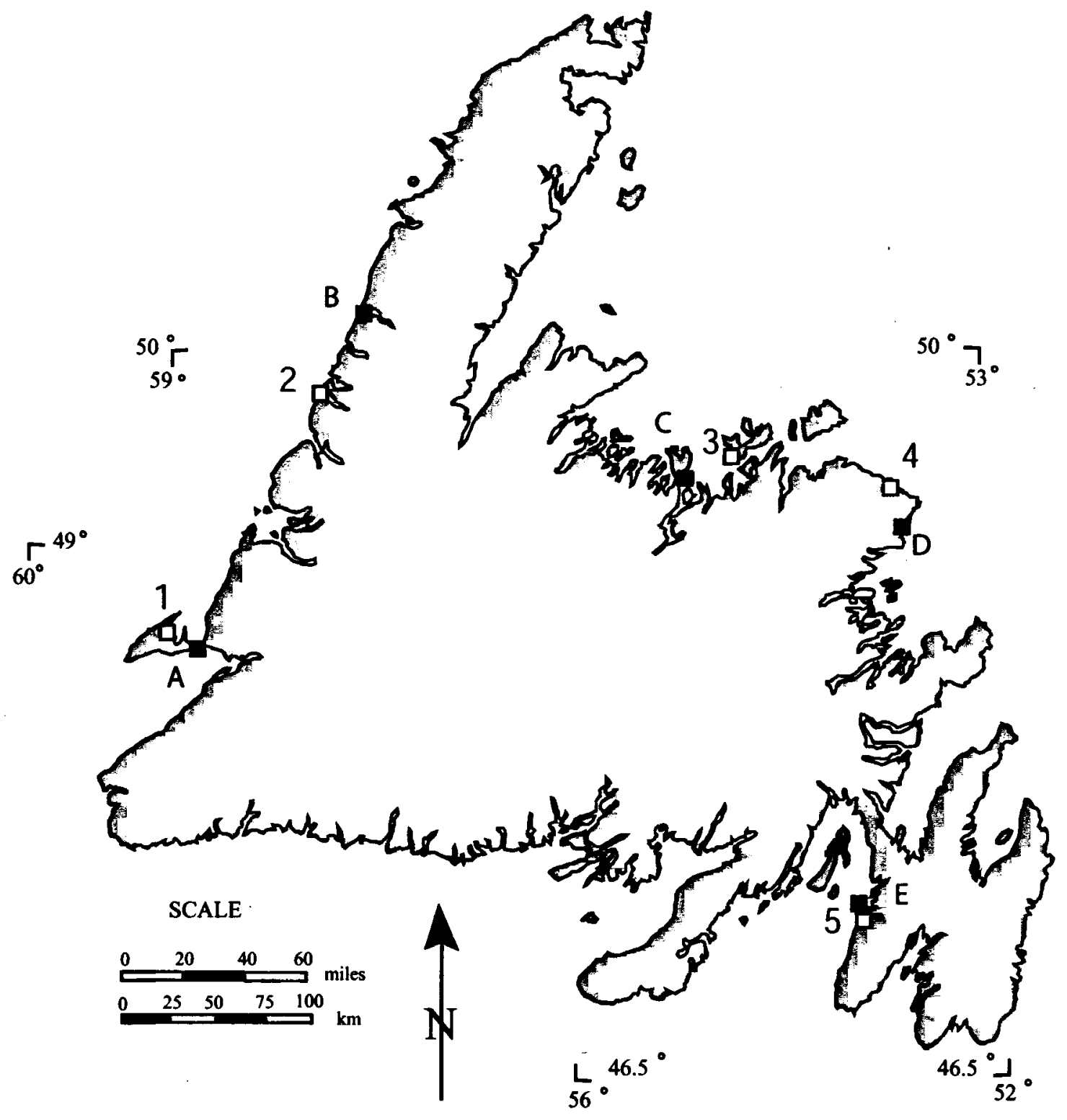

Figure 9.1 Location map showing study sites (ㅁ): 1) Hynes Brook, 2) St. Paul's Inlet, 3) Village Cove, New World Island, 4) Deadman's Bay, and 5) Southeast Arm, Placentia. Subordinate water level stations are ( $)$ : A) Port-au-Port, B) Portland Creek, C) Exploits Lower Hbr., D) Valleyfield, and E) Argentia. 


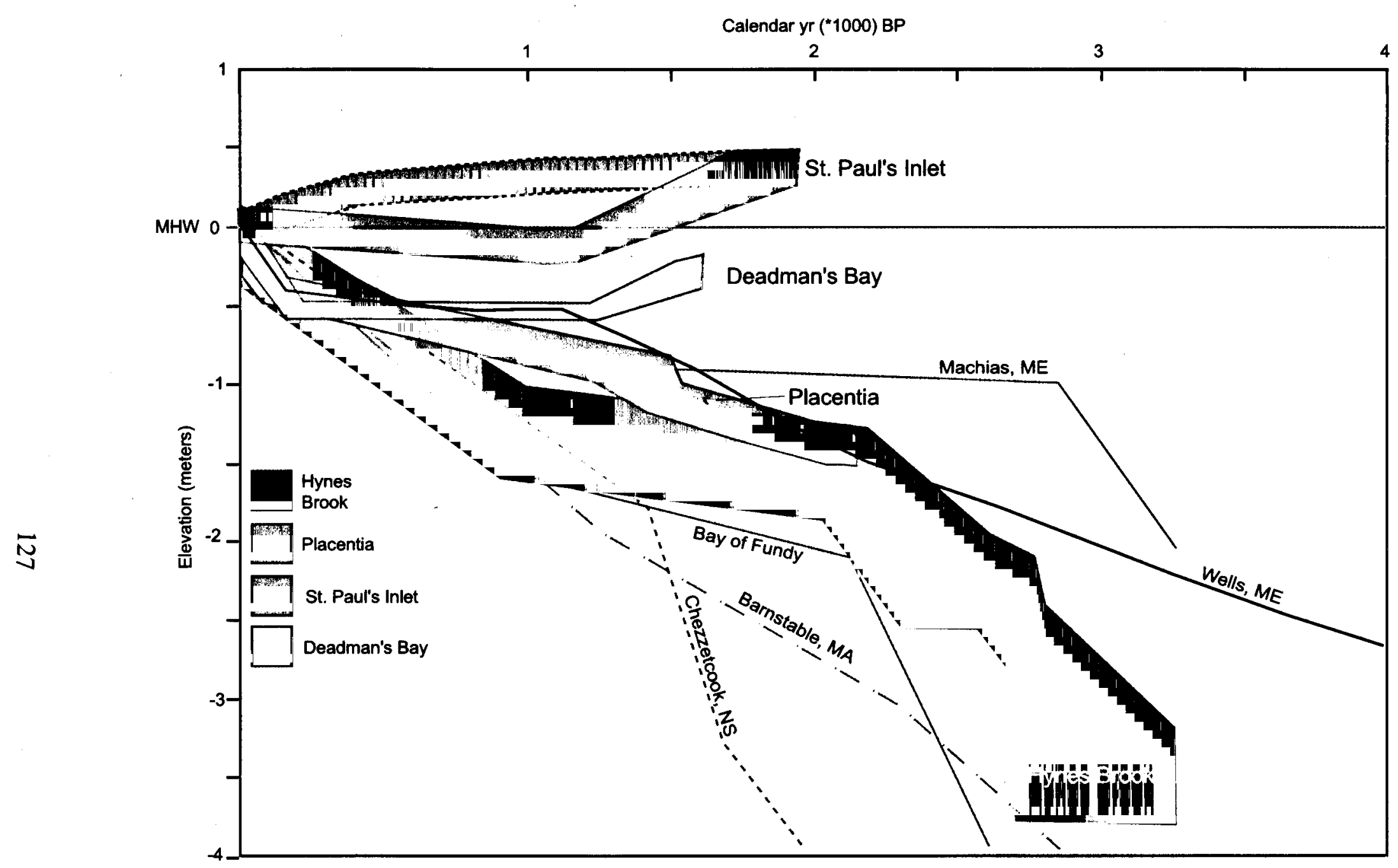

Figure 9.2 Comparison of late Holocene sea-level reconstructions for Newfoundland with sea-level envelopes from the Gulf of Maine. 
the island. The geographic trends of this difference are discussed further with reference to implications for location of a glacioisostatic hinge, forebulge migration, timing of deglaciation, and agreement or disagreement with numerical models.

\section{Comparison to Published Sea-level Reconstructions}

The sea-level reconstructions resulting from this study broadly agree with published sea-level histories, but provide much more constraint on sea level through time. Individual comparisons to other local curves are included in previous chapters. With the exception of Brookes et al. (1985), most previously published studies focused on early to mid-Holocene sea-level changes. These studies focused primarily on the emergent marine record or the nearshore record. The results of this study complement those efforts, and refine the late Holocene reconstructions. One major improvement over published work is the calibration of AMS ${ }^{14} \mathrm{C}$ dates. Calibrated dates provide a more accurate reconstruction of the rates of sea-level change, and are necessary to constrain numerical models.

The suite of Holocene sea-level curves for the west coast of Newfoundland is the most interesting for a broader discussion, and impacts subsequent interpretations of the isostatic hinge and migrating forebulge. Published sea-level curves for the west coast indicate a transition from a type B curve in the southwest to a type A or modified type A in the northeast (Figure 9.3). Based on research to date, it is considered uncertain whether the Northern Peninsula was ever submerged. Work in the area by Grant (1980, $1989,1992)$ indicates that the history of the tip of the Peninsula may represent continuous 

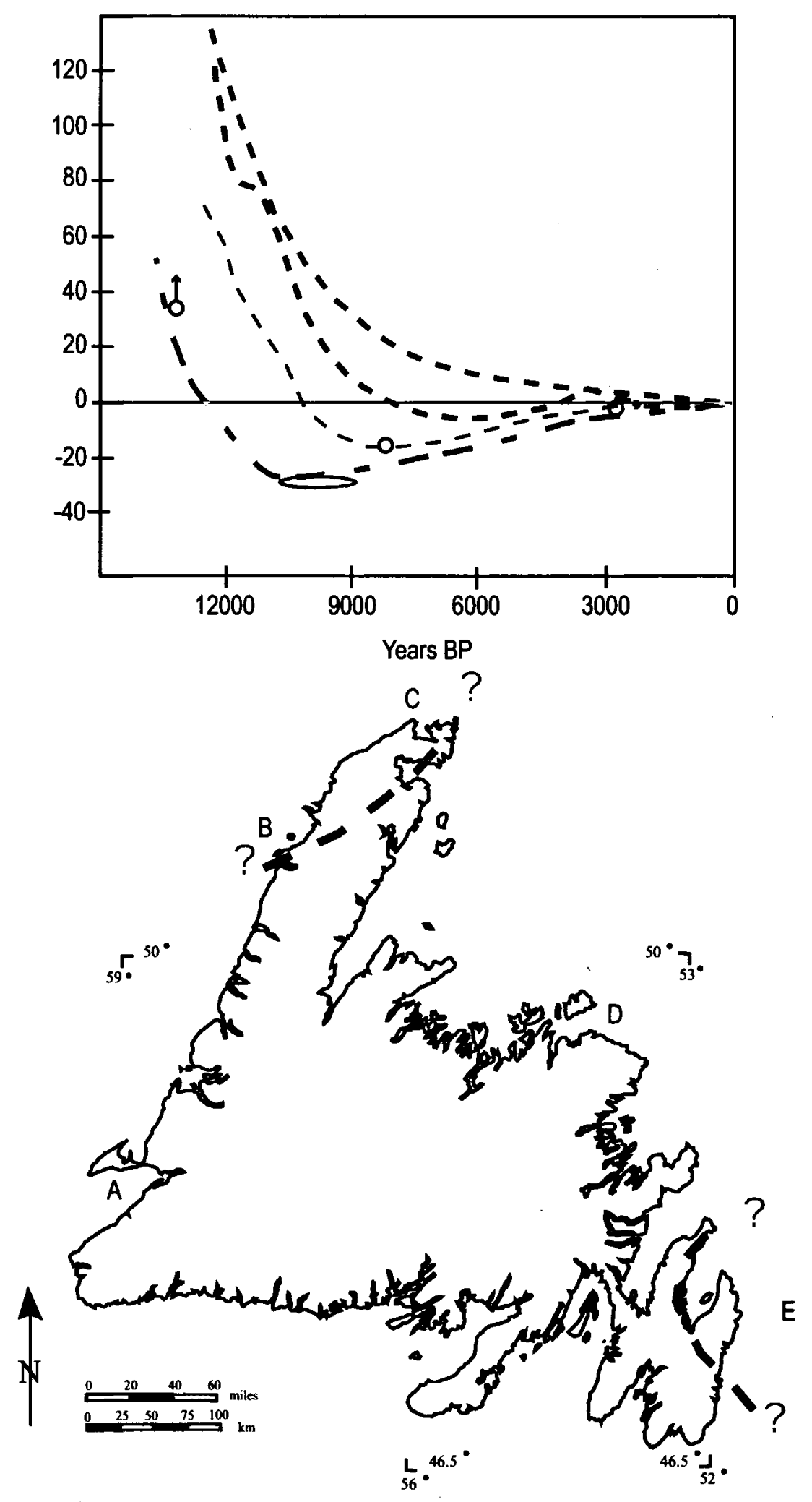

Figure 9.3 Comparison to sea-level curves from western NFLD

129 
emergence. Midway up the Peninsula, at Port-aux-Choix, Grant $(1992,1994)$ suggests a modified type A curve. Sea level may have briefly dropped below present between 8,000 $-5,000 \mathrm{yr} \mathrm{BP}$, then risen several meters above present by $3,000 \mathrm{yr} \mathrm{BP}$, and subsequently fallen to present. Results for the west coast support the type B curve characterizing the southwest (Port-au-Port area), but cannot confirm or refute the possibility of a modified type A curve for some or all of the Northern Peninsula. No evidence for marine transgression of the upper Northern Peninsula has been identified. Liverman (1994) suggests that it cannot be discounted as a possibility, but does not offer a mechanism for raising sea level nearly ten meters during the mid-Holocene. It may remain a possibility, but is not favored in this discussion due to both a lack of evidence and a mechanism for rapid changes.

\section{Glacioisostatic Hinge}

The glacioisostatic hinge is the transition from rising to falling sea level. Previous studies located the present position of the hinge at about $50-50.5^{\circ} \mathrm{N}$, transecting the Northern Peninsula (Figure 9.4) (Liverman, 1994; Shaw and Forbes, 1995). The location and orientation of the hingeline is not well constrained. Based on the age and distribution of emergent marine deposits, Liverman (1994) estimates that the hinge bisects the Northern Peninsula from Daniel's Harbour (on the west coast) to White Bay. In addition to emergent marine features, Shaw and Forbes (1995) consider offshore geophysical data indicating the postglacial lowstand. Their interpretation of these data locates the hinge line trending sharply NW-SE from $\sim 50^{\circ} \mathrm{N}$ (Figure 9.4). The zero meter contour follows other contoured lowstand depths to form a concentric ring around the island. Results of 


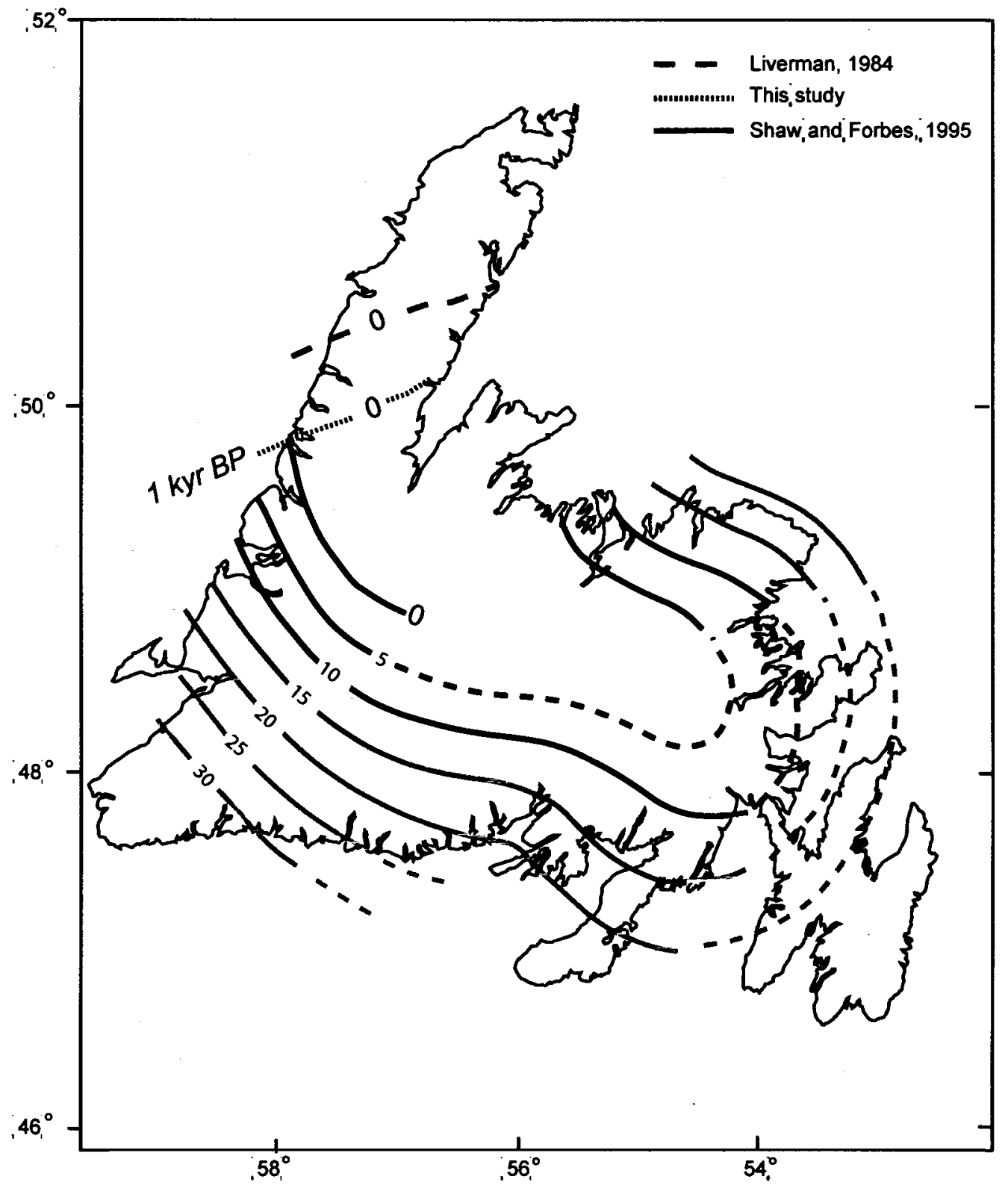

Figure 9.4 Postglacial sea-level lowstand (meters) and 0 isobase indicating the hinge line. Present location of the hinge is shown based on estimates from Liverman (1994) and Shaw and Forbes (1995). Location of the hinge 1 kyr BP is based on the results of this study. 
this study, specifically the sea-level reconstruction for St. Paul's Inlet, indicate that the hinge may have passed through $50^{\circ} \mathrm{N} \sim 1000$ yr BP (Figure 9.4). This is in agreement with Liverman's (1994) estimate for the present location of the hinge, and provides important spatial and temporal data regarding the migration of this feature.

The tide gauge data also support an E-W trending hinge (Figure 9.4) and a simpler pattern of isostatic uplift than that suggested by the Shaw and Forbes (1995) model. The Port-aux-Basques tide gauge indicates sea-level rise of $\sim 2 \mathrm{~mm} / \mathrm{yr}$ (Figure 3.3). Along the west coast, gauges to the north follow a trend of decreasing sea-level rise (Lark Harbour) to falling sea level (Savage Cove, Northern Peninsula) (Figure 3.3). Although the records from these locations are too short to use quantitatively, the gradual transition from rising to falling is in agreement with Liverman's (1994) estimated hinge.

\section{Migration of Collapsing Forebulge?}

The rate of migration of the isostatic hinge, based on the salt-marsh and tidegauge data, is estimated to be $50 \mathrm{~km} / \mathrm{kyr}(0.5 \mathrm{~km} / \mathrm{yr})$. The rate of forbulge migration from south to north along the west coast of Newfoundland is estimated to be $45 \mathrm{~km} / \mathrm{kyr}$ between 13,000 and $7,000{ }^{14} \mathrm{C}$ yr BP (Liverman, 1994). This rate is also consistent with the rate of forebulge migration calculated between Moosehead Lake (ME) and Quebec City (Balco et al., 1998), but si somewhat lower than the $70-110 \mathrm{~km} / \mathrm{kyr}$ rate estimated for the Gulf of Maine (Barnhardt et al., 1995). However, if this rate continued through the Holocene the forebulge should already have migrated to the north and west of the island. Liverman (1994) suggests that this passage may have occurred as early as 60007000 yr BP. The early Holocene passage of the forebulge would be consistent with at 
modified type A curve for the Northern Peninsula, but there is no strong evidence for this reconstruction.

Is the continued uplift of the northern tip of the Northern Peninsula the result of a migrating forebulge? If so, then the rate of forebulge migration either slowed considerably during the Holocene, or the estimates for late Pleistocene - early Holocene forebulge collapse are incorrect. Recent review of sea-level highstand indicators from the St. George's Bay area (Bell et al., 2001) suggest that a re-evaluation of these data is necessary. The late Holocene sea-level record described in this study cannot directly address this issue. However, if the record from St. Paul's Inlet is interpreted to show the first passage of sea level below present, the migration of the hinge line from St. Paul's Inlet north may be a proxy for the migration of the forebulge. Using available sea-level change data to constrain the migration of the forebulge remains problematic. Gravity anomaly data may provide limited support for the existence of a forebulge at the northern end of the Northern Peninsula. An isolated gravity low is centered on the northwest of the Northern Peninsula, just north of the approximate location of the hinge line (Figure 9.5) (Dehler and Roest, 1998). This low could be associated with the forebulge, but a more sophisticated analysis of these data is required to confirm this speculation.

\section{Comparison of Data to Numerical Models}

The long-term records extends the trends determined from tide-gauge records, which are the basis of popular glacioisostatic numerical models (Tushingham and Peltier, 1991; Peltier 2001, 2002). The long-term trends and tide gauge trends do not agree with 


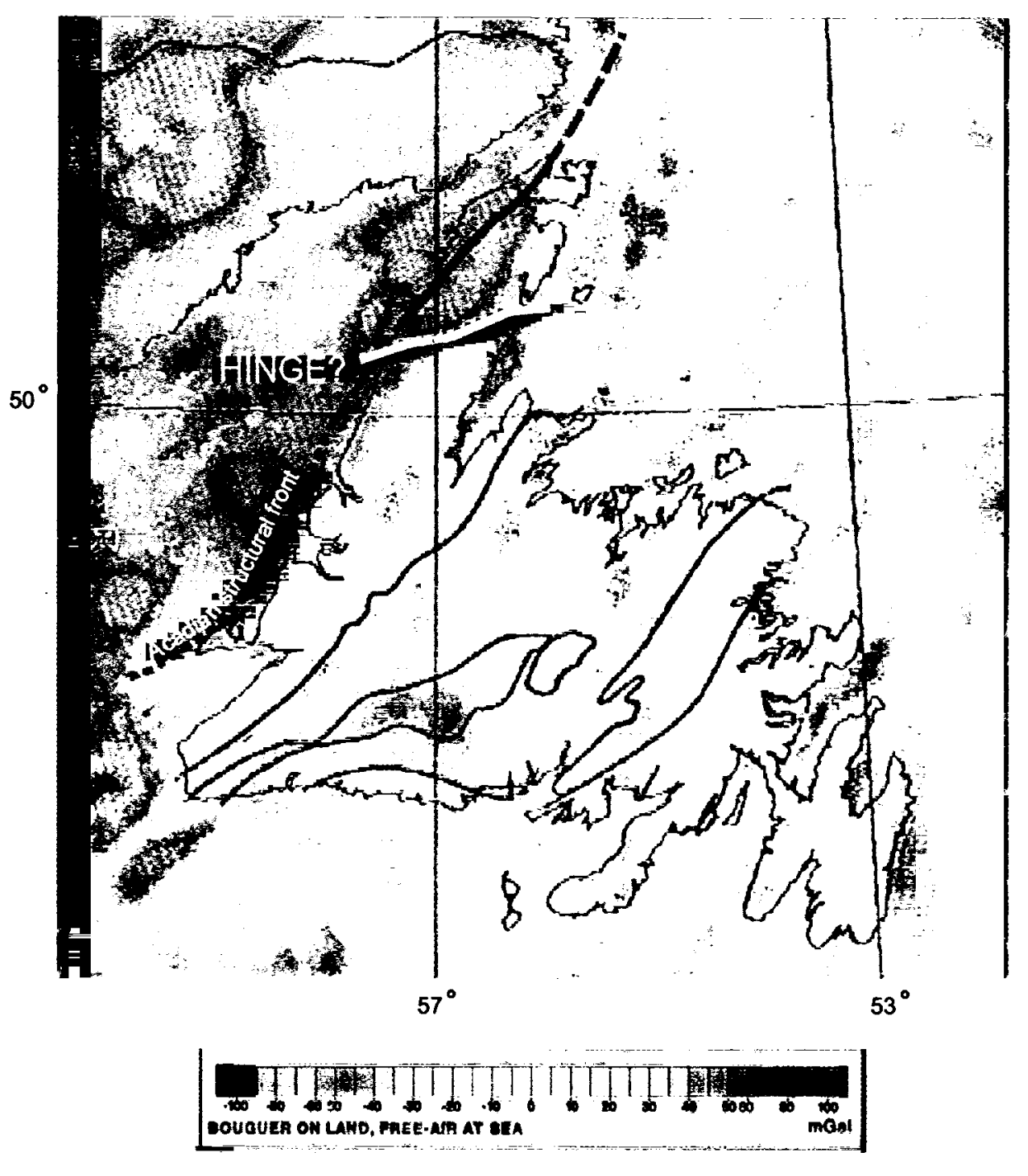

Figure 9.5 Gravity anomaly map of Newfoundland, from the Atlantic region gravity anomaly map of Dehler and Roest (1998). Note the gravity low in the northwest of the Northern Peninsula; the estimated position of the hingeline (Liverman, 1994) is indicated by a white line. 
numerical model predictions of sea-level change. Detailed models for Newfoundland are limited to those by Quinlan and Beaumont $(1981,1982)$, as discussed in Chapter 1. The sea-level reconstructions resulting from this project do not fit the zones estimated for 'minimum' or 'maximum' ice sheet models (Denton and Hughes, 1981). The 'maximum' model provides a closer fit to the data, but Quinlan and Beaumont (1981) acknowledge that neither model fits late Holocene data very well.

Comparison of these data to other predictive models for sea-level change is similarly unsatisfying. Global-scale models of glacioisostatic adjustment predict present sea-level change on a coarse grid, and it is difficult to determine whether the pattern predicted for Newfoundland (Peltier, 1999, 2001) corresponds to these new data. The location of the hinge may only be generally inferred from the most recent suite of sealevel trend predictions of the ICE-4G model (Peltier, 2001). The hinge predicted by that model passes through Newfoundland, but its exact location is not well defined (Figure 1.3). Other numerical models focus closely on the early Holocene to the exclusion of current trends (Dyke and Peltier, 2000). Thorleifson (2001) summarized the need to create more temporally and spatially detailed reconstructions and predictions of sea-level change. The definition of late Holocene sea-level trends using calibrated ages and vertically well constrained index points will provide important data for linking the tidegauge records with long-term changes. 


\section{Comparison to Maritimes and Gulf of Maine}

Comparing the Newfoundland sea-level changes to late Holocene records of sealevel change around the Gulf of Maine emphasizes the differentiation of sea-level trends across Newfoundland (Figure 9.1). This plot indicates that the southern field sites, Hynes Brook and Placentia, significantly overlap sea-level trends for the Maine coast. The trend of sea-level change at Deadman's Bay is less steep than any Gulf of Maine trend, while there is no overlap between the St. Paul's Inlet record and Gulf of Maine records. Correlating centennial or millenial rates of change among these records is not possible at this point. The Newfoundland records do not have enough index points to make them comparable to the Maine records.

The overlap between the southern Newfoundland sites and the Wells, ME and Machias, ME records confirm that the contours of isostatic uplift generally parallel the present shoreline. Previously published uplift patterns (Emery and Aubrey, 1991) are more convoluted than those predicted by analysis of tide-gauge and salt-marsh records in this study (Figure 3.5). The tide-gauge records indicate that the historic record supports shore-parallel contours. The salt-marsh records show that long-term late Holocene trends, at a contour interval of $2 \mathrm{~mm} / \mathrm{yr}$, are consistent with simpler contours as well. Considered together, the Newfoundland and Gulf of Maine late Holocene salt-marsh records show increased rates of mid-Holocene sea-level rise closer to the former Laurentide ice margin (more distal, thinner ice). This is consistent with late Holocene sea-level trends from Connecticut, which show greater rates of rise through the late Holocene than the Newfoundland records (Thomas and Varekamp, 2001; van de Plassche, 1998). 


\section{Chapter 10}

\section{CONCLUSIONS AND FUTURE WORK}

\section{Project Objectives and Conclusions}

Analysis of salt-marsh records at four sites and tide-gauge records from six sites around the island of Newfoundland constrain late Holocene sea-level change for this region. The reconstruction of sea-level change around the island addresses the following questions:

- Is there a significant geographic trend in sea-level change around the island during the late Holocene?

There is a significant geographic varaibility in sea-level change around the island during the late Holocene. Tide gauge data indicate historic sea-level rise around most of the island except for the northern half of the Northern Peninsula. Historic rates of rise may only be reliably estimated from four stations in the region. Estimates for local sealevel change on the Avalon Peninsula are $+1.6 \mathrm{~mm} / \mathrm{yr}$. Along the west coast, sea-level trends vary roughly north to south. At approximately $47^{\circ} \mathrm{N}$ (Port-aux-Basques), sea level is changing at $+2.3 \mathrm{~mm} / \mathrm{yr}$. On the west side of the Gulf of St. Lawrence, at $50^{\circ} \mathrm{N}$, sea level is falling slightly at $-0.7 \mathrm{~mm} / \mathrm{yr}$. The hinge between falling and rising sea level is estimated to extend northeast from this location across the Northern Peninsula.

There is a north-south geographic trend to millenial sea-level variability as well. Sea-level reconstructions for the southeast and southwestern parts of the island overlap, and indicate continuous sea-level rise at varying rates at these locations. In the northeast, sea level has remained close to present during the late Holocene, probably rising very slowly. At the base of the northern peninsula, sea level has also remained close to 
present through the late Holocene. Interpretation of the salt-marsh stratigraphy at this location indicates a more complex sea-level history. From $\sim 2000$ yr BP to $\sim 1000$ yr BP, sea level fell slightly at this location. Since $\sim 1000 \mathrm{yr} B P$, a transgressive stratigraphy has developed indicating sea-level rise. The transition from falling to rising sea level at this location delineates the position of the glacioisostatic hinge at $\sim 1000$ yr BP.

- How do late Holocene sea-level changes compare to historic sea-level trends? At each location, late Holocene sea level has risen at variable rates. Basal-peat samples best constrain rates of sea-level rise on the Avalon peninsula, and show a slower rate of rise prior to $\sim 500 \mathrm{yr} \mathrm{BP}$. The rate of present sea-level rise determined for sites in southern Newfoundland is more rapid than most past rates of change, but past rates have been variable. Available data are not comprehensive enough to address this question fully, but highlight the variability at each location and between locations during the late Holocene.

- Can the influence of glacioisostatic adjustment be determined from late Holocene sea-level trends?

Variable sea-level trends and millenial sea-level reconstructions are best explained as a continued isostatic response to deglaciation. This results of this research support the migration of a decaying marginal forebulge from southeast to northwest following deglaciation. The identification of the former position of the glacioisostatic hinge at St. Paul's Inlet allows a rate of $5 \mathrm{~km} / 100 \mathrm{yr}$ to be calculated for the rate of forebulge migration. This rate is somewhat slower than rates previously proposed for Newfoundland (Liverman, 1994). 
- Calibration of AMS ${ }^{14} \mathrm{C}$ dates is crucial to comparing millenial sea-level change to historic records and predictions from numerical models.

Recent discussions of numerical models do not compare the model results to calibrated radiocarbon dates (Peltier, 1999). This is critical, especially for constraining the timing of postglacial sea level highstands which are old enough that the radiocarbon age is a significant underestimate of the age in calendar years.

\section{Future Research}

This research builds on decades of related research in New England and the Maritime provinces. Future research may expand in three different areas: 1) sea-level change, 2) numerical models, and 3) application of sea-level change to pre-historic archeology.

Future sea-level change research related to this project may be focused on developing a more complete history or late Holocene sea-level change around Newfoundland, or on developing similar records of late Holocene sea-level change in isostatically uplifting areas. In Newfoundland, detailed ecological and geomorphological studies of the marshes investigated in this project will yield better insights into the dynamics of these salt marshes and barriers. Why aren't there more salt marshes? Is the frequency of tidal flooding the primary control on floral and foraminiferal distributions, as assumed in this study? At Hynes Brook, where the oldest dates were obtained, an expanded coring program may yield younger samples suitable for dating. This would facilitate construction of a curve from one location, and eliminate vertical uncertainties associated with assembling index points from several locations. Investigation of late 
Holocene uplift recorded by salt marsh peat preservation may be possible at other locations. Several broad wetlands on the coast of Hudson's Bay are possible targets; if they are fringed by salt marsh at present, it may be possible to trace this peat under freshwater material as it is uplifted.

Collaboration with geodynamicists is crucial to constrain numerical models predicting present rates of sea-level change, past ice configurations, and/or rheological properties of Earth. At present, there is a renewed interest in developing models that will accept greater spatial variability in rheology and deglacial history. Tuning these models will rely heavily on the existence of high-resolution sea-level records and updated analyses of tide gauge records. These models should address the behavior of the forebulge during deglaciation and its contribution to sea-level and lake-level change. Further research on lake-level change related to passage of a decaying forebulge may offer the best opportunities for extending records of crustal adjustment during deglaciation.

An additional application of late Holocene sea-level records is in paleogeographic reconstructions and archeology. Around Newfoundland and Labrador, most known prehistoric sites are associated with the shoreline. Detailed sea-level histories for different areas of the island are crucial for predicting the location and preservation potential of sites (Renouf and Bell, 2000). One current archeological problem in Newfoundland is resolving the apparent absence of sites older than $\sim 5000$ years, although there are older sites in nearby Labrador. It is likely that these older sites also exist in Newfoundland, but are either submerged or uplifted significantly depending on their location. 


\section{REFERENCES CITED}

Balco, G., Belknap, D.F., and Kelley, J.T., 1998, Glacioisostasy and lake-level change, Moosehead Lake, Maine: Quaternary Research, v. 49, p. 157-170.

Barnhardt, W.A., Gehrels, W.R., Belknap, D.F., and Kelley, J.T., 1995, Late Quaternary relative sea level change in the western Gulf of Maine: evidence for a migrating glacial forebulge: Geology v.23, p. 317-320.

Barnhardt, W.A., Belknap, D.F. and Kelley, J.T., 1997, Stratigraphic evolution of the inner continental shelf in response to late Quaternary relative sea-level change, northwestern Gulf of Maine: Geological Society of America Bulletin, v. 109, p. $612-630$

Batterson, M.J., Liverman, D.G.E., Catto, N.R., and Bell, T., 2001, The Quaternary geology of Newfoundland - A review: Geological Association of Canada / Mineralogical Association of Canada Annual Meeting, Abstracts Volume, p. 9.

Belknap, D.F., and Kraft, J.C., 1977, Holocene relative sea-level changes and coastal stratigraphic units on the northwest flank of the Baltimore Canyon trough geosyncline: Journal of Sedimentary Petrology, v. 47, p. 610-629.

Belknap, D.F., and Kraft, J.C., 1985, Influence of antecedent geology on stratigraphic preservation potential and evolution of Delaware's barrier systems: Marine Geology, v. 63, p. 235-262.

Belknap, D.F., Andersen, B.G., Anderson, R.S., Anderson, W.A., Borns, H.W., Jr., Jacobson, G.L., Kelley, J.T., Shipp, R.C., Smith, D.C., Stuckenrath, R., Jr., Thompson, W.B., and Tyler, D.A., 1987, Late Quaternary sea-level changes in Maine, in Nummedal, D., Pilkey, O., and Howard, J.D., eds., Sea-level fluctuation and coastal evolution: Society of Economic Paleontologists and Mineralogists Special Publication No. 41, p. 71-85.

Bell, T., Liverman, D.G.E., Batterson, M.J., and Sheppard, K., 2001, Late Wisconsinan stratigraphy and chronology of southern St. George's Bay, Newfoundland: a re-appraisal: Canadian Journal of Earth Sciences, v. 38, p. 851-869.

Brady, H.B., 1870, Analysis and descriptions of foraminifera, Part II: Annals and Magazine of Natural History, series 4, v. 6, p.273-309.

Brookes, I.A., 1974, Late-Wisconsin glaciation of southwestern Newfoundland (with special reference to the Stephenville map-area): Geological Survey of Canada, Paper 73-04.

Brookes, I.A., Scott, D.B., and McAndrews, J.H., 1985, Postglacial relative sea-level change, Port au Port area, west Newfoundland: Canadian Journal of Earth Sciences, v. 22 , p. 1039-1047. 
Brookes, I.A., and Stevens, R.K., 1985, Radiocarbon age of rock-boring Hiatella arctica (Linné) and postglacial sea-level change at Cow Head, Newfoundland: Canadian Journal of Earth Sciences, v. 22, p. 136-140.

Brönniman, P., Lutze, G.F., and Whittaker,J.E., 1989, Balticammina pseudomacrescens, a new brackish Trochamminid from the western Baltic Sea, with remarks on the wall structure: Meyniana, v. 41, p. 167-177.

Brönniman, P., and Whittaker,J.E., 1984, A lectotype for Jadammina macrescens (Brady) and emendation of Jadammina Bartenstein and Brand (protozoa: Foraminiferida): Bulletin of the British Museum of Natural History (Zool.), v. 46, p. 303-309.

Cabanes, C., Cazenave, A., and Le Provost, C., 2001, Sea level rise during past 40 years determined from satellite and in situ observations: Science, v. 294, p. 840-842.

CALIB 4.3, 2002, http://calib.org/calib/.

Canadian Hydrographic Service, 1999, data published in Tide Tables: East Coast of North and South America: International Marine, $370 \mathrm{p}$.

Catto, N.R., 2001, Coastal hazards in insular Newfoundland: Geological Association of Canada/Mineralogical Association of Canada Annual Meeting, Abstracts Volume, p. 23.

Clark, P.U., and Mix, A.C., 2002, Ice sheets and sea level of the Last Glacial Maximum: Quaternary Science Reviews, v. 21, p. 1-7.

Cushman, J.A., 1937, A monograph of the foraminiferal family Valvulinidae: Cushman Laboratory for Foraminiferal Research, Special Publication no. 8, $210 \mathrm{p}$.

Cushman, J.A., and Brönniman, P., 1948, Some new genera and species of foraminifera from brackish water of Trinidad: Contributions from the Cushman Laboratory for Foraminiferal Research, v. 24, p. 37-42.

Daly, J.F., Belknap, D.F., and Kelley, J.T., 1999, Indicative meaning of foraminifera and plants as a constraint of salt-marsh peat derived relative sea-level curves, Eos Transactions, v. 80, p. S182.

Daly, R.A., 1934, The Changeing World of the Ice Age: New Haven, Yale University Press, $271 \mathrm{p}$.

Davis, A.M., and Wickham, S.M., 1987, The microstratigraphy of two peat sequences from northeastern Newfoundland: Geographie physique et Quaternaire, v. 41, p. 355-364. 
Davis, J.L., and Mitrovica, J.X., 1996, Glacial isostatic adjustment and the anomalous tide gauge record of eastern North America: Nature, v. 379, p. 331-333.

de Rijk, S., 1995, Salinity control on the distribution of salt-marsh foraminifera (Great Marshes, Massachusetts: Journal of Foraminiferal Research, v. 25, p. 156-166.

de Rijk, S., and Troelstra, S., 1997, Salt marsh foraminifera from the Great Marshes, Massachusetts: environmental controls: Paleogeography, Paleoclimatology, Paleoecology, v. 130, p. 80-112.

de Rijk, S., and Troelstra, S., 1999, The application of a foraminiferal actuo-facies model to salt-marsh cores: Paleogeography, Paleoclimatology, Paleoecology, v. 149, p. 59-66.

Dehler, S.A., and Roest, W.R., 1998, Gravity anomaly map, Atlantic Region, Canada: Geological Survey of Canada Open File Report, 1 sheet.

Denton, G.H., and Hughes, T.J., 1981, The Last Great Ice Sheets: New York, Wiley, 484p.

Douglas, B.C., 2001, Sea level change in the era of the recording tide gauge, in Douglas, B.C., Kearney, M.S., and Leatherman, S.P., eds., Sea Level Rise: History and Consequences: New York, Academic Press, p. 37-64.

Douglas, B.C., and Peltier, W.R., 2002, The puzzle of global sea-level rise: Physics Today, v. 55, p. 35-40.

Dyke, A.S., and Peltier, W.R., 2000, Forms, response times and variability of relative sea-level curves, glaciated North America: Geomorphology, v. 32, p. 315-333.

El-Sabh, M.I., and Murty, T.S., 1986, Seasonal and long-term sea level variations in the Atlantic coast of Canada: Marine Geodesy, v. 10, p. 295-308.

Emery, K.O., and Aubrey, D.G., 1991, Sea Levels, Land Levels, and Tide Gauges: New York, Springer-Verlag, p. 127-134.

Forbes, D.L., Orford, J.D., Carter, R.W.G., Shaw, J., and Jennings, S.C., 1995, Morphodynamic evolution, self-organisation, and instability of coarse-clastic barriers on paraglacial coasts: Marine Geology, v. 126, p. 63-85.

Garlie, C.S., and Bell, T., 1997, Possible Raised Marine Sediments on the East Coast of the Avalon Peninsula, Newfoundland, Annual Meeting, Atlantic Geoscience Society, Amherst, Nova Scotia. 
Gehrels, W.R., 1994, Holocene sea-level changes in the northern Gulf of Maine: Regional trends and local fluctuations determined from foraminiferal analyses and paleotidal modelling: Unpublished Ph.D. thesis, University of Maine, 337p.

Gehrels, W.R., 1999, Middle and late Holocene sea-level changes in eastern Maine reconstructed from foraminiferal saltmarsh stratigraphy and AMS 14C dates on basal peat: Quaternary Research, v. 52, p. 350-359.

Gehrels, W.R., Belknap, D.F., Black, S., and Newnham, R.M., in press, Rapid sea-level rise in the Gulf of Maine since $1800 \mathrm{AD}$ : The Holocene.

Gehrels, W.R., Belknap, D.F., and Kelley, J.T., 1996, Integrated high-precision analyses of Holocene sea-level changes: Lessons from the coast of Maine: Geological Society of America Bulletin, v. 108, p. 1073-1088.

Gehrels, W.R., Roe, H.M., and Charman, D.J., 2001, Foraminifera, testate amoebae and diatoms as sea-level indicators in UK saltmarshes: a quatitative multiproxy approach: Journal of Quaternary Science, v. 16, p. 201-220.

Gehrels, W.R., and van de Plassche, O., 1999, The use of Jadammina macrescens (Brady) and Balticammina pseudomacrescens Brönniman, Lutze and Whittaker (Protozoa: Foraminiferida) as sea-level indicators: Paleogeography, Paleoclimatology, and Paleoecology, v. 149, p. 89-101.

Goldstein, S.T., and Harben, E.B., 1993, Taphofacies implication of infaunal foraminiferal assemblages in a Georgia salt marsh, Sapelo Island: Micropaleontology, v. 39, p. 53-62.

Goldstein, S.T., Watkins, G.T., Kuhn, R.M., 1995, Microhabitats of salt marsh foraminifera: St. Catherines, Georgia, USA: Marine Micropaleontology, v. 26, p. $17-29$.

Gornitz, V., 1995, A comparison of differences between Recent and late Holocene sealevel trends from eastern North America and other selected regions: Journal of Coastal Research, Special Issue no. 17, p. 287-297.

Grant, D.R., 1970, Recent coastal submergence of the Maritime Provinces, Canada: Canadian Journal of Earth Sciences, v. 7, p. 676-689.

Grant, D.R., 1987, Quaternary geology of Nova Scotia and Newfoundland, XIIth INQUA Congress Field Excursion A-3/C-3: Ottawa, National Research Council, 62 p.

Grant, D.R., 1994, Quaternary geology, Cape Breton Island, Nova Scotia: Geological Survey of Canada Bulletin, $168 \mathrm{p}$. 
Horton, B.P., Edwards, R.J., and Lloyd, J.M., 1999, A foraminiferal-based transfer function: Implications for sea-level studies: Journal of Foraminiferal Research, v. 29 , p. $117-129$.

Hughes, T.J., 1998, Ice Sheets. New York: Oxford University Press, 343 p.

Interactive wavelet analysis, http://ion.researchsystems.com/IONScript/wavelet/.

IPCC, 2002, Technical Summary of the Third Assessment Report, http://www.ipcc.ch/pub/wg1TARtechsum.pdf.

Kelley, J.T., Belknap, D.F., Jacobson, G.L. Jr., Jacobson, H.A., 1988, The morphology and origin of salt marshes along the glaciated coastline of Maine, USA: Journal of Coastal Research, v. 4, p. 649-666.

Kelley, J.T., Dickson, S.M., Belknap, D.F., and Stuckenrath, R., 1992, Sea-level change and the introduction of late Quaternary sediment to the southern Maine inner continental shelf, Wehmiller, J. and Fletcher, C., (eds.), Quaternary Coasts of the United States: Society of Economic Paleontologists and Mineralogists, Special Paper 48, p. 23-34.

Kelley, J.T., Belknap, D.F., and Daly, J.F., 2001, Comment on "North Atlantic ClimateOcean Variations and Sea Level in Long Island Sound, Connecticut, Since $500 \mathrm{cal}$ yr A.D." (van de Plassche, 2000) (Quaternary Research 53, 89-97), Quaternary Research, v. 55, p. 105-107.

Lincoln, J.M., and FitzGerald, D.M, 1988, Tidal distortion and flodd dominance at five small tidal inlets in southern Maine: Marine Geology, v. 82, p. 133-148.

Liverman, D.G.E., 1994, Relative sea-level history and isostatic rebound in Newfoundland, Canada: Boreas, v. 23, p. 217-230.

Loeblich, A.R., Jr., and Tappan, H., 1988, Foraminiferal Genera and Their Classification. New York: Van Nostrand Reinhold, 2 vol., 970 p., 847 plates.

Lowdon, J.A., Robertson, I.M., and Blake, W. Jr., 1977, Geological Survey of Canada radiocarbon dates XVII: Geological Survey of Canada, Paper 77-7, p. 3.

Marshall, S.J., James, T.S., Clarke, G.K.C., 2002, North American Ice Sheet reconstructions at the Last Glacial Maximum: Quaternary Science Reviews, v. 21, p. $175-192$.

Mayewski, P.A., Meeker, L.D., Whitlow,S., Twickler, M.S., Morrison, M.C., Grootes, P.M., Bond, G.C., Alley, R.B., Meese, D.A., Gow, A.J., Taylor, K.C., Ram, M. and Wumkes, M., 1994, Changes in atmospheric circulation and ocean ice cover over the North Atlantic during the last 41,000 years: Science, v. 263, p. 1747-1751. 
McIntyre, W.G., and Morgan, J.P., 1964, Recent Geomorphic History of Plum Island, Massachusetts and Adjacent Coasts: Baton Rouge, Louisiana State University Press, $44 \mathrm{p}$.

Milne, G.A., Davis, J.L., Mitrovica, J.X., Scherneck, H-G, Johannson, J.M., Vermeer, M., and Koivula, H., 2001, Sapce-geodetic constraints on glacial isostatic adjustment in Fennoscandia: Science, v. 291, p. 2381-2385.

Mudge, B.F., 1858, The salt marsh formations of Lynn: Proceedings of the Essex Institute, v. 2, p. 117-119.

Nerem, R.S., and Mitchum, G.T., 2001, Observations of sea level change from satellite altimetry, in Douglas, B.C., Kearney, M.S., and Leatherman, S.P., eds., Sea Level Rise: History and Consequences: New York, Academic Press, p. 121-164.

Nydick, K.R., Bidwell, A.B., Thomas, E., and Varekamp, J.C., 1995, A sea-level rise curve from Guilford, Connecticut, USA: Marine Geology, v. 124, p. 137-159.

Orson, R.A., Warren, R.S., and Niering, W.A., 1998, Interpreting sea level rise and rates of vertical marsh accretion in a southern New England tidal salt marsh: Estuarine, Coastal and Shelf Science, v. 47, p. 419-429.

Ozarko, D.L., Patterson, R.T., and Williams, H.F.L., 1997, Marsh foraminifera from Nanaimo, British Columbia (Canada): Implications of infaunal habitat and taphonomic biasing: Joumal of Foraminiferal Research, v. 27, p. 51-68.

Parker, F.L. and Athearn, W.D., 1959, Ecology of marsh foraminifera in Poponesset Bay, Massachusetts: Journal of Paleontology, v. 33, p. 333-343.

Peltier, W.R., 1999, Global sea level rise and glacial isostatic adjustment: Global and Planetary Change, v. 20, p. 93-123.

Peltier, W.R., 2001, Global glacial isostatic adjustment and modern instrumental records of relative sea level history, in Douglas, B.C., Kearney, M.S., and Leatherman, S.P., eds., Sea Level Rise: History and Consequences: New York, Academic Press, p. 65-96.

Peltier, W.R., 2002, On eustatic sea level history: Last Glacial Maximum to Holocene: Quaternary Science Reviews, v. 21, p. 377-396.

Permanent Service for the Study of Mean Sea Level, http://www.pol.ac.uk/psmsl/.

Phleger, F.B., 1954, Ecology of formainifera and associated microorganisms from Mississippi Sound and environs: Bulletin of the American Association of Petroleum Geologists, v. 38, p. 584-647. 
Pirrazoli, P.A., 1991, World Atlas of Holocene Sea-Level Changes: Amsterdam, Elsevier Ocean Series no. 58, 300p.

Quinlan, G., and Beaumont, C., 1981, A comparison of observed and theoretical postglacial relative sea level in Atlantic Canada: Canadian Journal of Earth Sciences, v. 18 , p. 1146-1163.

Quinlan, G., and Beaumont, C., 1982, The deglaciation of Atlantic Canada as reconstructed from the postglacial relative sea-level record: Canadian Journal of Earth Sciences, v. 19, p. 2232-2246.

Renouf, M.A.P. and Bell, T., 2000, Integrating Sea Level History and Geomorphology in Targeted Archaeological Site Survey: The Gould Site (EeBi-42), Port au Choix, Newfoundland: Northeastern Anthropology, v. 59, p. 47-64.

Redfield, A.C., and Rubin, M., 1962, The age of salt marsh peat and its relation to recent changes in sea level at Barnstable, Massachusetts: Proceedings of the National Academy of Sciences, v. 48, p. 1728-1735.

Saffert, H., and Thomas, E., 1998, Living foraminifera and total populations in salt marsh peat cores: Kelsey Marsh (Clinton, CT) and the Great Marshes (Barnstable, MA): Marine Micropaleontology, v. 33, p. 175-202.

Scott, D.B., 1976, Brackish-water foraminifera from southern California and description of Polysaccammina ipohalina n. gen., n. sp.: Journal of Foraminiferal Research, v. 17 , p. 101-105.

Scott, D.B., Boyd, R., and Medioli, F.S., 1987, Relative sea-level changes in Atlantic Canada: Observed level and sedimentological changes vs. theoretical models, Wehmiller, J. and Fletcher, C., (eds.), Quaternary Coasts of the United States: Society of Economic Paleontologists and Mineralogists, Special Paper 48, p. 23-34.

Scott, D.B., Brown, K., Collins, E.S., and Medioli, F.S., 1995, A new sea-level curve from Nova Scotia: evidence for a rapid acceleration of sea-level rise in the late midHolocene: Canadian Journal of Earth Sciences, v. 32, p. 2071-2080.

Scott, D.B., and Greenberg, D.A., 1983, Relative sea-level rise and tidal development in the Fundy tidal system: Canadian Journal of Earth Sciences, v. 20, p. 1554-1564.

Scott, D.B., and Medioli, F.S., 1978, Vertical zonations of marsh foraminifera as accurate indicators of former sea-levels: Nature, v. 272, p. 528-531.

Scott, D.B., and Medioli, F.S., 1980, "Quantitative Studies of Marsh Foraminiferal Distributions in Nova Scotia: Implications for Sea-Level Studies": Cushman Foundation for Foraminiferal Research Special Publication no. 17, pp. 1-57. 
Scott, D.B., and Medioli, F.S., 1982, Micropaleontological documentation for early Holocene fall of relative sea level on the Atlantic coast of Nova Scotia: Geology, v. 10, p. $278-281$.

Scott, D.B., Medioli, F.S., and Schafer, C.T., 1977, Temporal changes in foraminiferal distribution in Miramichi River Estuary, New Brunswick: Canadian Journal of Earth Sciences, v. 15, p. 1566-1587.

Scott, D.B., Medioli, F.S., and Schafer, C.T., 2001, Monitoring in Coastal Envirnoments Using Foraminifera and Thecamoebian Indicators: Cambridge University Press, $177 \mathrm{p}$.

Scott, D.B., Schnack, E.S., Ferrero, L., Espinosa, M., and Barbosa, C.F., 1990, Recent marsh foraminifera from the east coast of South America: comparison to the northern hemisphere, in Hemleben, C., Kaminski, M.A., Kuhnt, W., and Scott, D.B., eds., Paleoecology, Biostratigraphy, Paleoceanography and Taxonomy of Agglutinated Foraminifera: NATO ASI Series C. 327, Math and Physical Sciences, p. 717-738.

Scott, D.B., Suter, J.R., and Kosters, E.C., 1991, Marsh foraminifera and arcellaceans of the lower Mississippi Delta: controls on spatial distribution: Micropaleontology, v. 37 , no. 4, p. 373-392.

Shaler, 1886, Preliminary report on sea-coast swamps of the eastern United States: U.S. geological Survey $6^{\text {th }}$ Annual Report, p. 353-398.

Shaw, J., and Edwardson, K.A., 1994, Surficial sediments and post-glacial sea-level history, Hamilton Sound: Atlantic Geology, v. 30, p. 97-112.

Shaw, J., and Forbes, D.L., 1990, Relative sea-level change and coastal response, northeast Newfoundland: Journal of Coastal Research, v. 6, p. 641-660.

Shaw, J., and Forbes, D.L., 1992, Barriers, barrier platforms, and spillover deposits in St. George's Bay, Newfoundland: Paraglacial sedimentation on the flanks of a deep coastal basin: Marine Geology, v. 105, p. 199-140.

Shaw, J., and Forbes, D.L., 1995, The postglacial relative sea-level lowstand in Newfoundland: Canadian Journal of Earth Sciences, v. 32, p. 1308-1330.

Stea, R.R., Piper, D.J.W., Fader, G.B.J., and Boyd, R., 1998, Wisconsinan glacial and sea-level history of Maritime Canada and adjacent continental shelf, a correlation of land and sea events: Geological Society of America Bulletin, v. 110 , p. $821-845$.

Stuiver, M., and Reimer, P.J., 1993, Extended ${ }^{14} \mathrm{C}$ database and revised CALIB 3.0 radiocarbon calibration program: Radiocarbon, v. 35, p. 215-230. 
Thomas, E., and Varekamp, J.C., 1991, Paleo-environmental analyses of marsh sequences (Clinton, Connecticut): Evidence for punctuated rise in relative sealevel during the latest Holocene: Journal of Coastal Research Special Issue no. 11, p. $125-158$.

Thorleifson, L.H., 2001, Measurement and modelling of glacial isostatic adjustment (conference report): Geoscience Canada, v. 28, p. 156-158.

Todd, R., and Brönniman, P.,1957, Recent foraminifera and thecamoebina from the eastern Gulf of Paria: Cushman Foundation for Foraminiferal Research, Special Publication 3, $43 \mathrm{p}$.

Törnqvist, T.E., van Ree, M.H.M., van 't Veer, R., and van Geel, B., 1998, Improving methodology for high-resolution reconstruction of sea-level rise and neotectonics by paleoecological analysis and AMS $14 \mathrm{C}$ dating of basal peats: Quaternary Research, v. 49, p. 72-85.

van Heteren, S., FitzGerald, D.M., Barber, D.C., Kelley, J.T., and Belknap, D.F., 1996, Volumetric analysis of a New England barrier system using ground-penetrating Radar and coring techniques: Journal of Geology, v. 104, p. 471-483.

van de Plassche, O., 1991, Late Holocene sea-level fluctuations on the shore of Connecticut inferred from transgressive and regressive overlap boundaries in saltmarsh deposits: Journal of Coastal Research Special Issue no. 11, p. 159-179.

van de Plassche, O., van der Borg, and de Jong, A.F.M., 1998, Sea level - climate correlation during the past 1400 yr: Geology, v. 26, p. 319-322.

Varekamp, J.C., and Thomas, E., 1998, Climate Change and the rise and fall of sea level over the millenium: Eos (Transactions, American Geophysical Union), v. 79, p. 69-75.

Varekamp, J.C., Thomas, E., and Thompson, W.G., 1999, Sea level-climate correlation during the past 1400 yr: Comment: Geology, v. 27, p. 189-190.

Varekamp, J.C., Thomas, E., and van de Plassche, O., 1992, Relative sea-level rise and climate change over the last 1500 years (Clinton, CT, USA): Terra Nova, v. 4, p. 293-304.

Wigley, T.M.L., and Raper, S.C.B., 1987, Thermal expansion of sea water associated with global warming: Nature, v. 330, p. 127-131.

Williamson, W.C., 1858, On Recent Foraminifera of Great Britain: London, Ray Society, $107 \mathrm{p}$.

Wright and van de Plassche, 2001, GAC-MAC field guide to Quaternary west coast of Newfoundland. 


\section{Appendix A}

\section{SYSTEMATIC TAXONOMY}

Identifications follow de Rijk and Troelstra (1997) and Gehrels and van de Plassche (1999). Generic names follow the descriptions of Loeblich and Tappan (1988).

Balticammina pseudomacrescens Brönniman, Lutze, and Whittaker, 1989

Plate I, figs. 2-4

Trochammina macrescens Scott and Medioli, 1980, p. 39, pl. 3, figs. 1-3.

Trochammina macrescens f. macrescens Scott et al., 1990, p. 737, pl. 1, fig. 1a, b. Trochammina macrescens (type A) De Rijk, 1995, pl. 1, figs. 1-3.

Balticammina pseudomacrescens Brönniman, Lutze, and Whittaker, 1989, p.169, pls. 1-3, Gehrels and van de Plassche, 1999, p. 98, pl. 1, figs. 6-10.

Jadammina macrescens (Brady, 1870)

Plate I, fig. 1

Trochammina inflata (Montagu) var. macrescens Brady, 1870, p. 290, pl. 11, figs. 5a-c. Jadammina polystoma Parker and Athearn, 1959, p. 341, pl. 50, figs. 21, 22, 27; Scott and Medioli 1980, p. 39, pl. 3, figs. 9-11.

Trochammina macrescens Brady. Parker and Athearn, 1959, p. 341, pl. 50, figs. 23-25; Scott and Medioli, 1980, pl. 3, figs. 4-8.

Trochammina macrescens f. polystoma Scott et al., 1990, p. 737, pl. 1, fig. 2a-c. Jadammina macrescens (Brady) Brönniman and Whittaker, 1984, p. 305, figs. 1-15; Gehrels and van de Plassche, 1999, p. 98, pl. 1, figs. 1-5.

Discussion: The distinction between Balticammina and Jadammina follows the descriptions made by de Rijk and Troelstra (1997) and Gehrels and van de Plassche (1999). As noted by these authors, the major distinguishing feature is the open umbilicus and slightly inflated chambers of Balticammina. Gehrels (1998, pers. comm.) also noted that the dorsal side of the chambers are frequently collapsed for fossil Balticammina.

\section{Eggerella advena (Cushman)}

Plate II, fig. 9

Eggerella advena Cushman, 1937, p. 51, pl. 5, figs. 12-15; Scott et al., 1977, p. 1579, pl. 2, fig. 7; Scott and Medioli, 1980, p. 40, pl. 2, fig. 7.

\section{Haplophragmoides sp.}

Haplophragmoides manilaensis Scott et al., 1990, p. 730, pl. 1, figs. 9a, b; Scott et al., 1991 , p. 385, pl. 1, figs. 18, 19.

Haplophragmoides bonplandi Todd and Brönniman, 1957, p. 23, pl. 2, fig. 2. Scott and Medioli, 1980, p. 40, pl. 2, figs. 4, 5.

Remarks: Usually characteristic of low-salinity high marsh areas (Scott et al., 2001). This genera was not identified to the species level in this study, and occurred rarely. 
Miliammina fusca (Brady)

Plate II, figs. 1-3

Quinqueloculina fusca Brady, 1870, p. 286, pl. 11, figs., 2,3.

Miliammina fusca (Brady). Phleger, 1954, p. 642, pl. 2, figs. 22, 23; Scott et al., 1977, p. 1579, pl. 2, figs., 8,9; Scott and Medioli, 1980, p. 40, pl. 2, figs. 1-3.

\section{Polysaccammina ipohalina Scott}

Plate II, figs. 6-8

Polysaccammina ipohalina Scott, 1976, p. 318, pl. 2, figs. 1-4; Scott and Medioli, 1980, p. 43, pl. 2, figs. 8-11; Scott et al., 1991, p. 386, pl. 2, fig. 3.

Tiphotrocha comprimata (Cushman and Brönniman)

Plate I, figs. 7-9

Trochammina comprimata Cushman and Brönniman, 1948, p. 41, pl. 8, figs. 1-3;

Phleger, 1954, p. 646, pl. 3, figs. 20, 21.

Tiphotrocha comprimata (Cushman and Brönniman). Scott et al., 1977, p. 1579, pl. 4, figs. 3, 4; Scott and Medioli, 1980, p. 44, pl. 5, figs. 1-3; Scott et al., 1990, pl. 1, figs.

$10 \mathrm{a}, \mathrm{b}$.

Trochammina inflata (Montagu) Kornfeld, 1931

Plate I, figs. 5,6

Nautilus inflatus Montagu, 1808, p. 81, pl. 18, fig. 3.

Rotalina inflata Williamson, 1858, p. 50, pl. 4, figs. 93, 94.

Trochammina inflata (Montagu). Phleger, 1954, p. 646, pl. 3, figs. 22, 23; Scott et al., 1977, p. 1579, pl. 4, figs. 6,7; Scott and Medioli, 1980, p. 44, pl. 3, figs. 12-14, pl. 4, figs. 1-13; Scott et al., 1990, p. 733, pl. 1, figs. 3a, b; Scott et al., 1991, p. 388, pl. 2, figs. 7, 8.

Trochamminita salsa (Cushman and Brönniman)

Plate II, figs. 4,5

Labrospira salsa Cushman and Brönniman, 1948, p. 17, pl. 4, figs. 1-3. 


\section{Plate I.}

Figure 1.J. macrescens, ventral view.

Figure 2. B. pseudomacrescens, ventral view.

Figure 3. B. pseudomacrescens, deformed test, ventral view.

Figure 4. B. pseudomacrescens, close-up view of slit-shaped aperture.

Figure 5. T. inflata, dorsal view.

Figure 6. T. inflata, ventral view.

Figure 7. T. comrimata, dorsal view.

Figure 8. T. comrimata, juvenile (?), ventral.

Figure 9. T. comrimata, ventral view.

\section{Plate II.}

Figure 1. M. fusca, coarse-grained test.

Figure 2. $M$. fusca, fine-grained test.

Figure 3. M. fusca, close-up of aperture.

Figure 4. T. salsa, slightly oblique side view.

Figure 5. T. salsa, view of multiple areal apertures on outermost chamber.

Figure 6. P. ipohalina

Figure 7. P. ipohalina

Figure 8. $P$. ipohalina

Figure 9. E. advena 


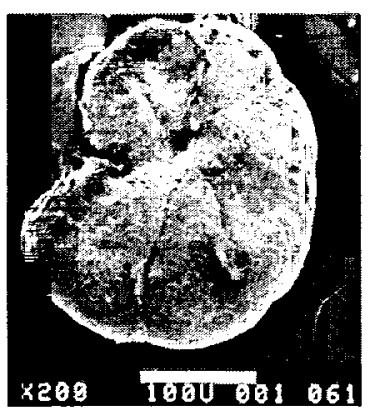

1
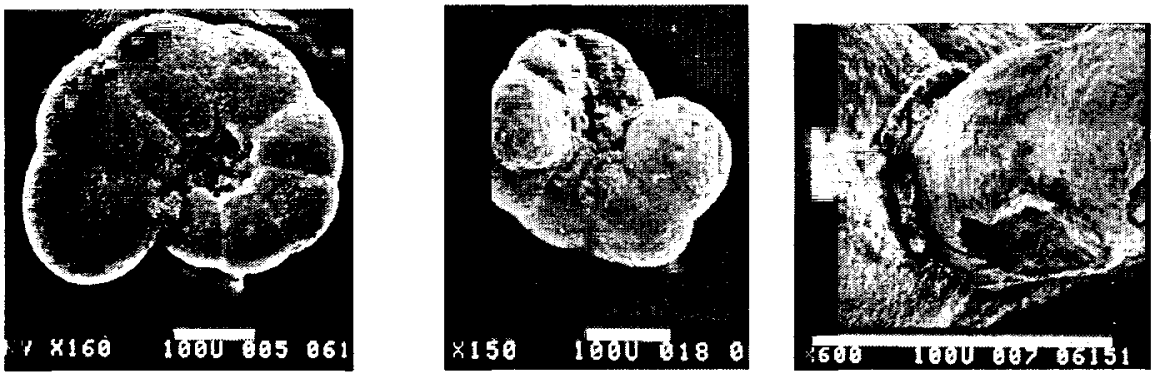

2

3

4
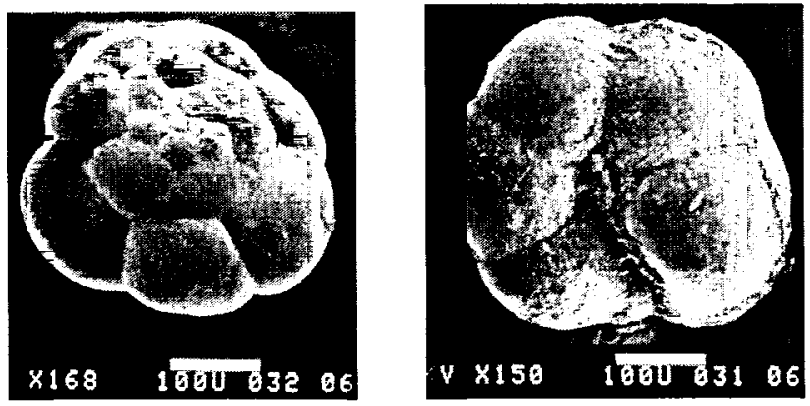

5

6

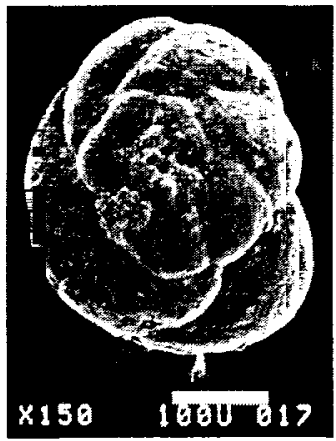

7
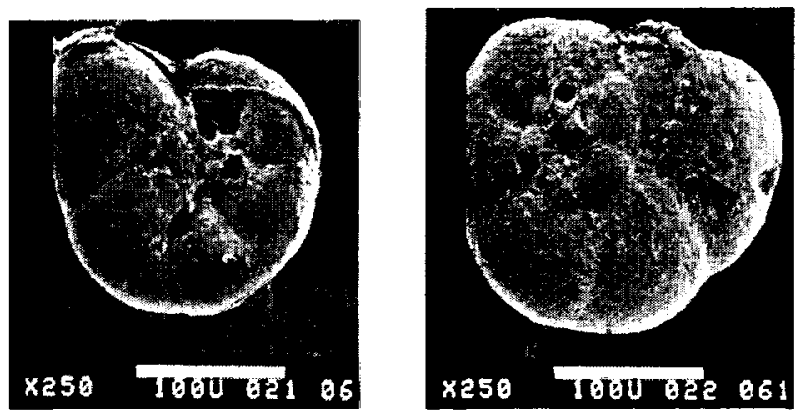

8

9

Plate I., SEM images of foraminifera. 1),J. macrescens, 2-4), B. pseudomacrescens 5-6), $T$. inflata, and 7-9) T. comprimata. 


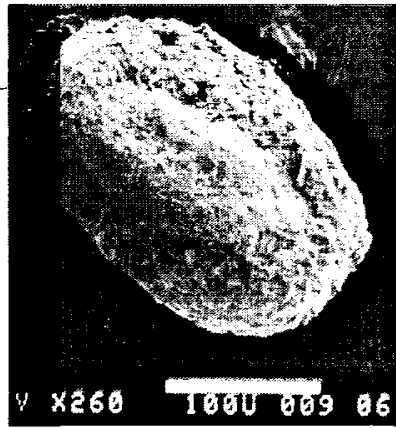

1

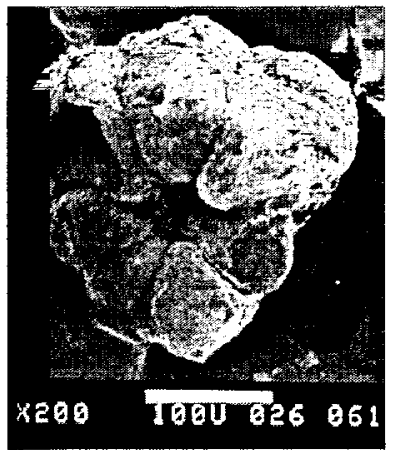

4

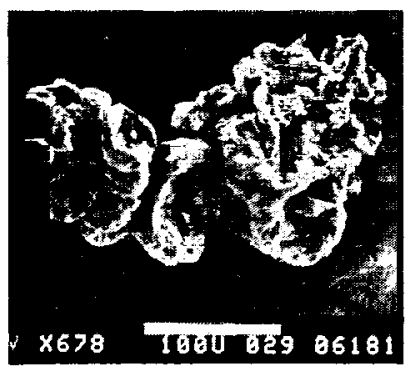

6

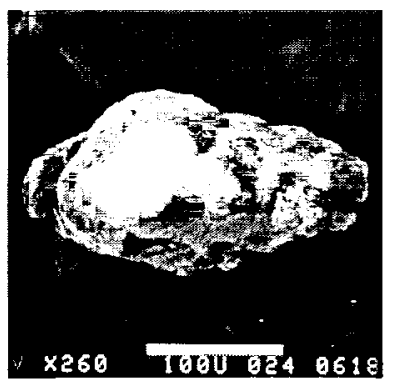

9

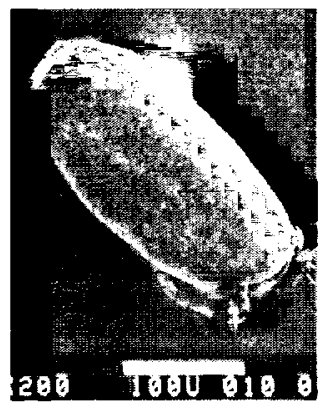

2

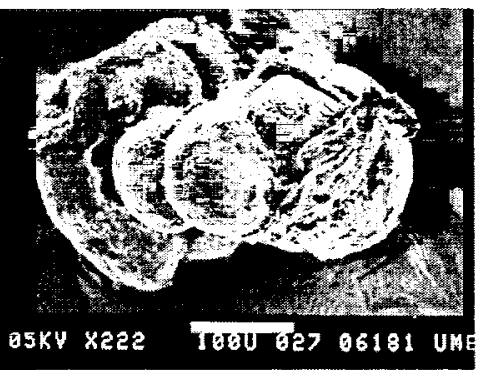

5

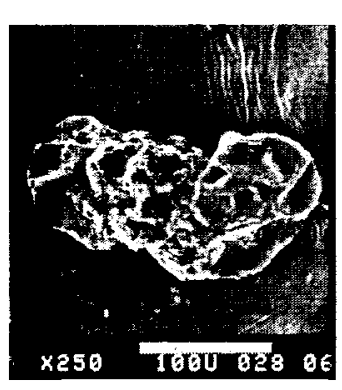

7

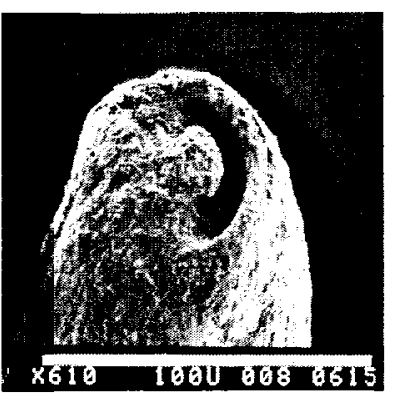

3

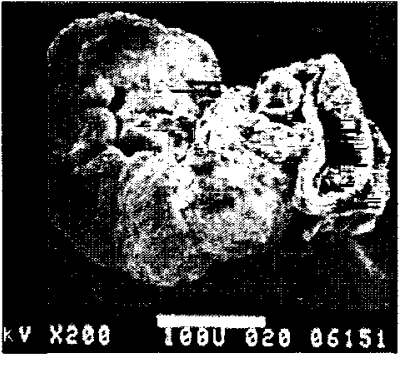

8

Plate II.. SEM images of foraminifera. , 1-3), M. fusca,4-5), T. salsa 6-8). P. ipohalina, 9) E. advena. 
Appendix B

FORAMINIFERA COUNTS 
Raw numbers

\begin{tabular}{|c|c|c|c|c|c|c|c|c|c|c|}
\hline Sample no. & J. macre & B. pseudo & T. inflata & T. compri & Haplo & M. fusca & P. ipohal & T. salsa & Other & TOTAL \\
\hline PL-F1 & 6 & 7 & 0 & 0 & 0 & 0 & 0 & 0 & o 3 & \begin{tabular}{|l|l}
3 & 13 \\
\end{tabular} \\
\hline PL-F2 & 47 & 28 & 0 & 4 & 1 & 9 & 0 & $\underline{0}$ & 0 & 89 \\
\hline PL-F3 & 43 & 24 & 12 & 5 & 4 & 8 & 0 & 10 & 2 & 108 \\
\hline PL-F4 & 38 & 31 & 5 & 11 & 0 & 13 & 2 & 0 & 0 & 100 \\
\hline PL-F5 & 66 & 18 & 36 & 8 & 0 & 10 & 1 & $\underline{0}$ & 2 & 141 \\
\hline PL-F6 & 43 & 13 & 8 & 11 & 2 & 28 & 1 & 0 & 1 & $10^{7}$ \\
\hline PL-F7 & 43 & 21 & 0 & 0 & 13 & 11 & 0 & 10 & 5 & 103 \\
\hline PL-F8 & 39 & 31 & 51 & 7 & 1 & 5 & 0 & 0 & 2 & 136 \\
\hline PL-1-3 & 24 & 13 & 7 & 33 & 1 & 2 & $\underline{0}$ & $\underline{0}$ & 12 & 92 \\
\hline SPI-F1 & 19 & 27 & 1 & 0 & 0 & 3 & 0 & 0 & & 50 \\
\hline SPI-F2 & 24 & 12 & 2 & 0 & 1 & 0 & 0 & 0 & & 39 \\
\hline SPI-F3 & 6 & 1 & 0 & 0 & 0 & 2 & 0 & $\underline{0}$ & - & $s$ \\
\hline SPI-F4 & 10 & 25 & & & & 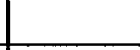 & 2 & 2 & & 37 \\
\hline SPI-F5 & 19 & 0 & 7 & g & 0 & 0 & $\underline{0}$ & $\underline{0}$ & & 26 \\
\hline SPI-F6 & 12 & 35 & & & & 1 & 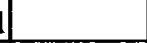 & & & 48 \\
\hline SPI-F12 & 0 & 0 & 0 & 0 & 0 & 0 & 0 & 0 & 0 & c \\
\hline SPI-F13 & 0 & 0 & 0 & 0 & 0 & 0 & 0 & $\mathbf{0}$ & 0 & o \\
\hline SPI-F14 & 7 & 5 & & & & 3 & 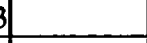 & & 2 & 17 \\
\hline SPI-F15 & 44 & 6 & 2 & 0 & 0 & 2 & 0 & 0 & 1 & 55 \\
\hline PW-F1 & 44 & 51 & 8 & 8 & 7 & 13 & $\mathbf{0}$ & 0 & & 13 \\
\hline PW-F2 & 74 & 78 & 15 & 9 & 8 & 28 & 0 & 0 & & 212 \\
\hline PW-F3 & 44 & 35 & 13 & 11 & 2 & 17 & 2 & 2 & 0 & 120 \\
\hline PW-F4 & 36 & 48 & & 10 & & 2 & 2 & & & 96 \\
\hline PW-F5 & 38 & 13 & 3 & 1 & 6 & 6 & $\mathbf{0}$ & 0 & 0 & 67 \\
\hline PW-F6 & 30 & 8 & 1 & d & 1 & 14 & 0 & 0 & 1 & 55 \\
\hline PW-F7 & 16 & 2 & & & . & & & & & 18 \\
\hline PW-F11 & 89 & 36 & & 2 & 1 & 3 & 3. & & & 125 \\
\hline PW-F12 & 113 & 39 & 0 & 0 & 14 & 4 & $\mathbf{0}$ & 0 & 0 & 17 \\
\hline PW-F13 & 32 & 63 & & 2 & 9 & 1 & 1 & & & $10^{\circ}$ \\
\hline PW-F14 & 57 & 60 & 4 & 6 & 22 & 2 & 0 & $\underline{0}$ & 1 & 152 \\
\hline PW-F15 & 3 & 0 & 0 & 0 & 1 & 9 & 0 & $\underline{0}$ & & 13 \\
\hline VC-F1 & 23 & 129 & 4 & 1 & 0 & 5 & 0 & 0 & & 162 \\
\hline VC-F2 & 32 & 84 & 0 & d & g & 11 & $\underline{0}$ & $\underline{0}$ & 0 & 127 \\
\hline VC-F3 & 49 & 56 & 0 & 0 & 0 & 4 & o & $\underline{0}$ & & 109 \\
\hline VC-F4 & 76 & 76 & 0 & 1 & 0 & 1 & 0 & 0 & 1 & 155 \\
\hline VC-F5 & 97 & 50 & 0 & d & 1 & 1 & 0 & 0 & 0 & 149 \\
\hline VC-F6 & 27 & 65 & 0 & 1 & 1 & 0 & 0 & 0 & 0 & 94 \\
\hline VC-F7 & 13 & 8 & 0 & d & 0 & 0 & 0 & 0 & & 21 \\
\hline VC-F8 & 12 & 11 & 0 & 0 & 0 & 0 & 0 & 0 & & 23 \\
\hline DB-F1 & 0 & 0 & 0 & 0 & 0 & 0 & 0 & $\underline{0}$ & 0 & c \\
\hline DB-F2 & $d$ & 0 & 0 & $d$ & 0 & 0 & 0 & 0 & $d$ & d \\
\hline
\end{tabular}




\begin{tabular}{|c|c|c|c|c|c|c|c|c|c|c|c|c|c|}
\hline Depth & Volume Split & J. macre I & B.pseudo & T. inflate & T. compri & Haplo & M. fusce & A. mexic & P. ipohal & h. salsa & Other & TOTAL & Total/ce \\
\hline $\begin{array}{l}\text { Corre:- } \\
\text { - }\end{array}$ & BuV-19 & 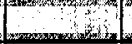 & 28 & Wom & & & When & arisina & & & & Som & $L^{5} \times$ \\
\hline $50-51$ & $11 / 8$ & 29 & 17 & 26 & 5 & 3 & 29 & & & & & 109 & 872 \\
\hline $70-71$ & $11 / 8$ & 12 & 5 & & & & 1 & 1 & & & & 18 & 144 \\
\hline $120-121$ & $11 / 8$ & 3. & & & & & 5 & 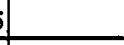 & & & & 8 & 64 \\
\hline $200-201$ & $\left.1\right|_{1 / 8}$ & 55 & 21 & 25 & 1 & 29 & 12 & & & & & 143 & 1144 \\
\hline $232-233$ & $1 \mid 1 / 8$ & 34 & 29 & 20 & 9 & 1 & 132 & 2 & 2 & & & 227 & 1816 \\
\hline$\underline{235-236}$ & $11 / 8$ & 27 & 33 & 11 & 3 & 4 & 8 & 1 & & & & 90 & 720 \\
\hline Corein & $\mathrm{BW}-20$ & & & & & & & & & & & & \\
\hline $140-141$ & $11 / 8$ & 35 & 19 & & & & & & & & & 54 & \\
\hline $140-141$ & $17 / 64$ & 16 & 6 & & 1 & 1 & 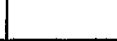 & & & & & 24 & \\
\hline $140-141$ & $15 / 64$ & 51 & 25 & 0 & 1 & 1 & 0 & 0 & $\underline{0}$ & 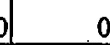 & 0 & 78 & 333 \\
\hline 181-182 & $11 / 8$ & 4 & 8 & & & & & & & & & 12 & \\
\hline 181-182 & $11 / 8$ & 9. & 5 & & & & 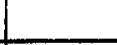 & & & & & 14 & \\
\hline $181-182$ & $15 / 64$ & 13 & 13 & 0 & 0 & 0 & 0 & 0 & 0 & 0 & 0 & 26 & 111 \\
\hline $188-189$ & $1 \mid 1 / 8$ & 4 & 2 & & & & & & & & & 6 & 48 \\
\hline Core: & PW-21 & 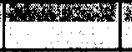 & 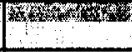 & 站 & & & & & & & & 4 & 11 \\
\hline $253-254$ & $11 / 8$ & 81 & 67 & 2 & & & 24 & & & 1 & & 175 & 1400 \\
\hline $256-257$ & $11 / 8$ & 41 & 36 & 6 & & 2 & 3 & & & & & 82 & \\
\hline$\underline{256-257}$ & $11 / 8$ & 35 & 37 & 3 & & 1 & 6 & & & - & & 82 & \\
\hline $256-257$ & 37260 & 76 & 73 & 3 & 0 & 3 & 9 & 0 & 0 & 0 & & 164 & 1312 \\
\hline Core: & PW-24, & & & & & 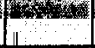 & & & & & & & \\
\hline 96-97 & $1 \mid 1 / 8$ & 18 & 28 & 5 & & & & & & & 1 & 52 & 416 \\
\hline $105-107$ & $1 \mid 1 / 8$ & 25 & 21 & 2 & & & & & & & & 48 & \\
\hline 105-107 & $17 / 64$ & 10 & 23 & 1 & & & & & & & & 34 & \\
\hline 105-107 & $15 / 64$ & 35 & 44 & 3 & 0 & 0 & 0 & 0 & 0 & 0 & d & 82 & 350 \\
\hline $110-111$ & $11 / 8$ & 1 & 3 & & & & & & & & & 4 & 32 \\
\hline Core: & $P W_{-25}$ & 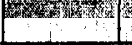 & and & & & & & & 14 & & 11 & & 4 \\
\hline $96-97$ & $1 \mid 1 / 8$ & 2 & 6 & & & & & & & & & 8 & 64 \\
\hline 104-105 & 1]1/8 & 12 & 4 & 2 & & 1 & & & & & 1 & 20 & 160 \\
\hline $109-110$ & $11 / 8$ & 2 & 4 & & & & 1 & $\perp$ & & & & 7 & 56 \\
\hline
\end{tabular}




\begin{tabular}{|c|c|c|c|c|c|c|c|c|c|c|c|c|c|c|}
\hline Depth & Volume & Split & J. macre & B. pseudo & T. inflata & T. compri & Haplo & M. fusca & A. mexic & P. ipohal & T. salsa & Other & TOTAL & Total/ce \\
\hline Core: & PW-19 & & & & 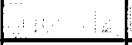 & . & & & & & & in & 6 & $\therefore$ \\
\hline 50-51 & & $11 / 8$ & 29 & 17 & 26 & 5 & 3 & 29 & & & & & 109 & 872 \\
\hline $70-71$ & & $11 / 8$ & 12 & 5 & & & & 1 & & & & & 18 & 144 \\
\hline $120-121$ & & $11 / 8$ & 3 & & & & & 5 & & & & & 8 & 64 \\
\hline 200-201 & & $11 / 8$ & 55 & 21 & 25 & 1 & 29 & 12 & & & & & 143 & 1144 \\
\hline$\underline{232-233}$ & & $11 / 8$ & 34 & 29 & 20 & 9 & 1 & 132 & 2 & & & & 227 & 1816 \\
\hline$\underline{235-236}$ & & $11 / 8$ & 27 & 33 & 11 & 3 & 4 & 8 & 1 & 1 & 1 & 2 & 90 & 720 \\
\hline Core: & $\mathrm{PW}-20$ & & $t$ & 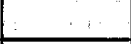 & & 1 & 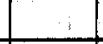 & & & $:$ & & & 2 & 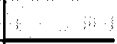 \\
\hline $140-141$ & & $11 / 8$ & 35 & 19 & & & & & & & & & 54 & \\
\hline $140-141$ & & $17 / 64$ & 16 & 6 & & 1 & 1 & & & & & & 24 & \\
\hline $140-141$ & & $15 / 64$ & 51 & 25 & 0 & 1 & 1 & $\underline{0}$ & 0 & 0 & 0 & ) & 78 & 333 \\
\hline$\underline{181-182}$ & & $11 / 8$ & 4 & 8 & & 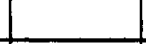 & t & 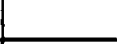 & 1 & & & & 12 & \\
\hline 181-182 & & $11 / 8$ & 9 & 5 & & 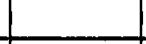 & 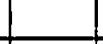 & & 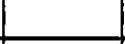 & & & & 14 & \\
\hline $181-182$ & & $15 / 64$ & 13 & 13 & 0 & 0 & 0 & $\underline{0}$ & 0 & 0 & 0 & ] & 26 & 111 \\
\hline 188-189 & & $1 \mid 1 / 8$ & 4 & 2 & & & & & & & & & 6 & 48 \\
\hline Core: & PW-21 & & 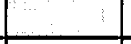 & & & & & & & & & & 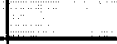 & \\
\hline $253-254$ & & $11 / 8$ & 81 & 67 & 2 & 2 & & 24 & & & 1 & 1 & 175 & 1400 \\
\hline $256-257$ & & $11 / 8$ & 41 & 36 & 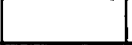 & & 2 & 3 & & & & & 82 & \\
\hline 256-257 & & $11 / 8$ & 35 & 37 & 3 & 3 & 1 & 6 & & & & & 82 & \\
\hline $256-257$ & & 37260 & 76 & 73 & 3 & 0 & 3 & 9 & 0 & 0 & 0 & 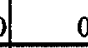 & 164 & 1312 \\
\hline Core: & $\mathrm{PW}-24$ & & 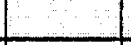 & ter & 1 & & & & 1 & & & & 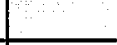 & 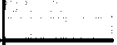 \\
\hline 96-97 & & $11 / 8$ & 18 & 28 & 5 & 5 & & & & & & 1 & 52 & 416 \\
\hline$\underline{105-107}$ & & $1 / 18$ & 25 & 21 & 2 & 2 & & & & & & & 48 & \\
\hline 105-107 & & $17 / 64$ & 10 & 23 & 1 & if & & & & & & & 34 & \\
\hline $105-107$ & & $15 / 64$ & 35 & 44 & 3 & 0 & 0 & $\underline{0}$ & 0 & 0 & 0 & d & 82 & 350 \\
\hline$\underline{110-111}$ & & $11 / 8$ & 1 & 3 & & & & & & & & & 4 & 32 \\
\hline Core: & PW-25 & & 1 & & & & & & & & & & & \\
\hline $96-97$ & & $11 / 8$ & 2 & 6 & & & & & & & & & 8 & 64 \\
\hline 104-105 & & 1 1/8 & 12 & 4 & 2 & 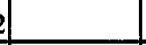 & 1 & & & & & 1 & 20 & 160 \\
\hline 109-110 & & $11 / 8$ & 2 & 4 & & & & 1 & & & & & 7 & 56 \\
\hline
\end{tabular}




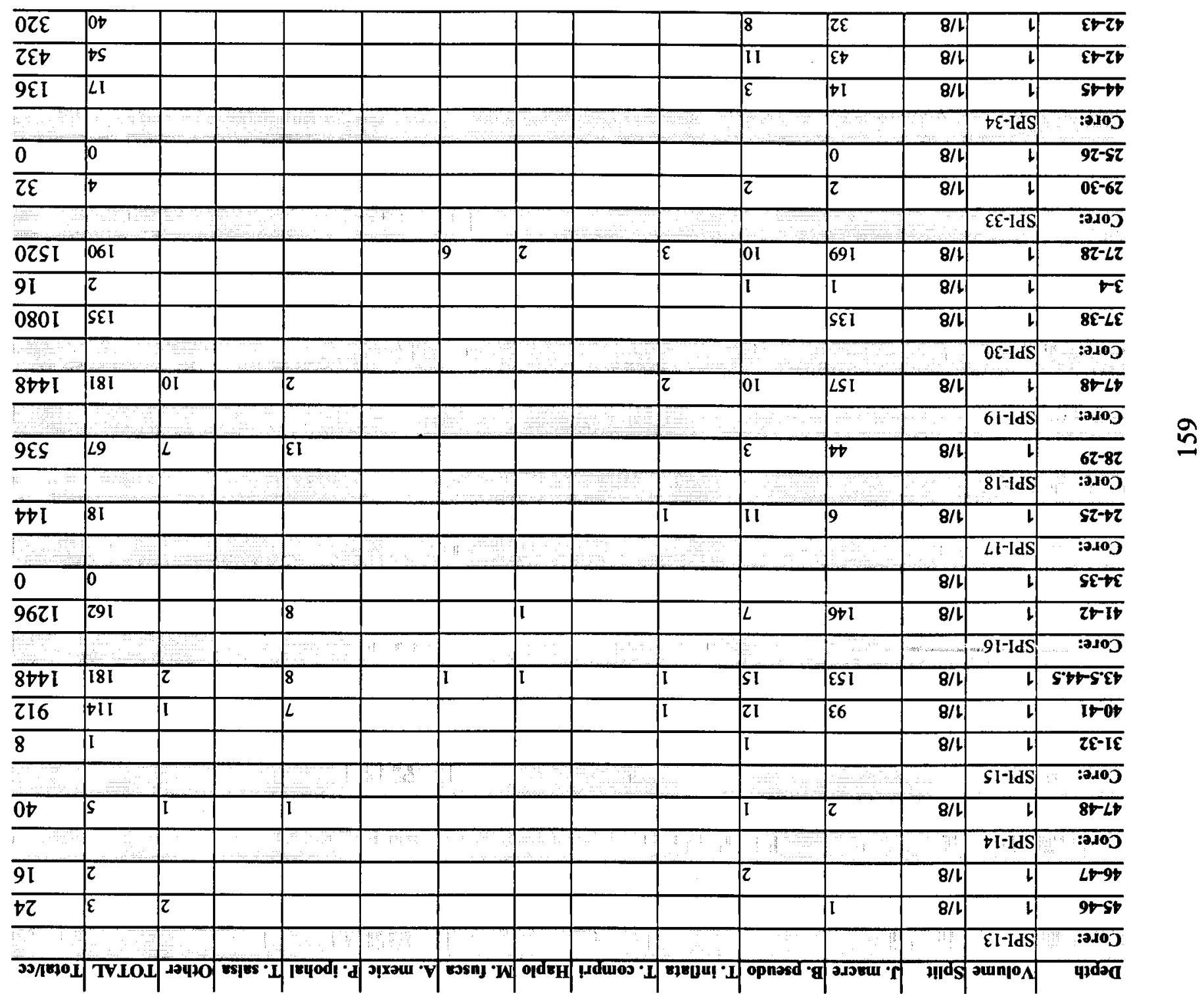




\begin{tabular}{|c|c|c|c|c|c|c|c|c|c|c|c|c|c|c|}
\hline $50 L$ & 88 & 8 & 1 & 1 & 1 & $z$ & & & 1 & $s$ & $\varepsilon L$ & \multicolumn{2}{|c|}{$8 / I \mid I$} & 98-58 \\
\hline$\overline{Z 6 L}$ & 66 & $L$ & & & & & & & $t$ & $\angle 2$ & 19 & \multicolumn{2}{|c|}{\begin{tabular}{l|l|l|}
$8 / \mathrm{I}$ & $\mathrm{I}$ \\
\end{tabular}} & $\overline{10 I-001}$ \\
\hline$t$ & tol & 2 & & & & I & & & $\varepsilon$ & $E \varepsilon$ & $\$ 9$ & \multicolumn{2}{|c|}{ t9/SI $\mid \mathrm{I}$} & IZI-0ZI \\
\hline & $\angle \mathcal{E}$ & & & & & & & & I & $D I$ & $\overline{2 z}$ & \multicolumn{2}{|c|}{$t 99 / L I I$} & $\overline{\text { IZI-0ZI }}$ \\
\hline & $\angle 9$ & 2 & & & & I & & & $z$ & $6 I$ & $\varepsilon t$ & \multicolumn{2}{|c|}{\begin{tabular}{l|l|l}
$8 / \mathrm{I}$ & $\mathrm{I}$ \\
\end{tabular}} & IZI-0ZI \\
\hline 0021 & OSI & & & & & & & & 62 & Iद & 06 & \multicolumn{2}{|c|}{$\begin{array}{l}8 / \mathrm{I} \\
\end{array}$} & $0 \notin I-6 \varepsilon I$ \\
\hline & & & & & & & & & & & & & I-Td & $: 2,100$ \\
\hline 79 & 8 & & & I & & $z$ & & & I & $\mathcal{E}$ & I & \multicolumn{2}{|c|}{$8 / 11$} & $\overline{56-76}$ \\
\hline & & & & & & & & & & & & & $61 * 80$ & $: 2.100$ \\
\hline $826 \mathrm{I}$ & Itz & I & & & $\varepsilon$ & $9 I$ & & & & 18 & $00+\mathrm{I}$ & \multicolumn{2}{|c|}{$8 / \mathrm{I}$} & $6 \mathrm{SS-85}$ \\
\hline & & & & & & & & & & & & & $81 \cdot 8 \mathrm{a}$ & $: 2.100$ \\
\hline 08 & 01 & & & & & J & & & & $\varepsilon$ & 9 & \multicolumn{2}{|c|}{$8 / 1 / 1$} & $8+\angle t$ \\
\hline $8+2$ & IE & & & & $I$ & $D$ & I & & & 8 & $\angle I$ & \multicolumn{2}{|c|}{$8 / 1 \mathrm{I}$} & $6 \mathrm{6S-8S}$ \\
\hline & & & & & & & & & & & & & $4 \cdot 80$ & $: 2000$ \\
\hline $0 z \varepsilon$ & $0 t$ & & & & & I & & & & $\varepsilon z$ & 91 & \multicolumn{2}{|c|}{$8 / 11$} & $05-6 t$ \\
\hline & & & & & & & & 1 & & & & 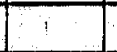 & $91-8 \mathrm{ga}$ & $: 2100$ \\
\hline 0 & 0 & & & & & & & & & & & \multicolumn{2}{|c|}{$8 / \pi 6^{\circ} 0$} & tSI-ESI \\
\hline$\longrightarrow$ & 1 & & 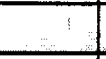 & & & & & & & & & & si-ga & $: 2.200$ \\
\hline$\overline{z \varepsilon}$ & $t$ & & & I & & & & & & $z$ & 1 & $8 / 1$ & & $6 \varepsilon-8 \varepsilon$ \\
\hline $8 t$ & 9 & & & & & & & & & & 9 & \multicolumn{2}{|c|}{$\begin{array}{l}8 / \mathrm{I} \\
\end{array}$} & $8 L-L L$ \\
\hline \multirow[t]{2}{*}{8} & $i$ & & & & & & & & & & 1 & \multicolumn{2}{|c|}{$8 / 1[1$} & 19-09 \\
\hline & & 11 & & & & & & & $\because 4$ & & & & $\varepsilon \mathfrak{E}-\mathrm{qd}$ & $: 2100$ \\
\hline 201 & $\hbar z$ & & & & & & & & I & 71 & 6 & \multicolumn{2}{|l|}{ t9/SI } & $8 \varepsilon-\angle \varepsilon$ \\
\hline \multirow[t]{2}{*}{0 ott } & $s s$ & & & & & & & I & & $8 \mathcal{E}$ & $9 \mathrm{I}$ & \multicolumn{2}{|c|}{$8 / \mathrm{l} / \mathrm{I}$} & $8 \varepsilon-\angle \varepsilon$ \\
\hline & 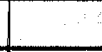 & $\ldots$ & & & & & & & & 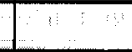 & & \multirow{2}{*}{\multicolumn{2}{|c|}{\begin{tabular}{|c|c|} 
& $21-80$ \\
$! \mid d s$ & 2umpos
\end{tabular}}} & $: 2000$ \\
\hline & & & & & & & & 00.1 & & if opna & ספנג & & & पग्वव \\
\hline
\end{tabular}


Appendix C

AMS ${ }^{14} C$ DATA 

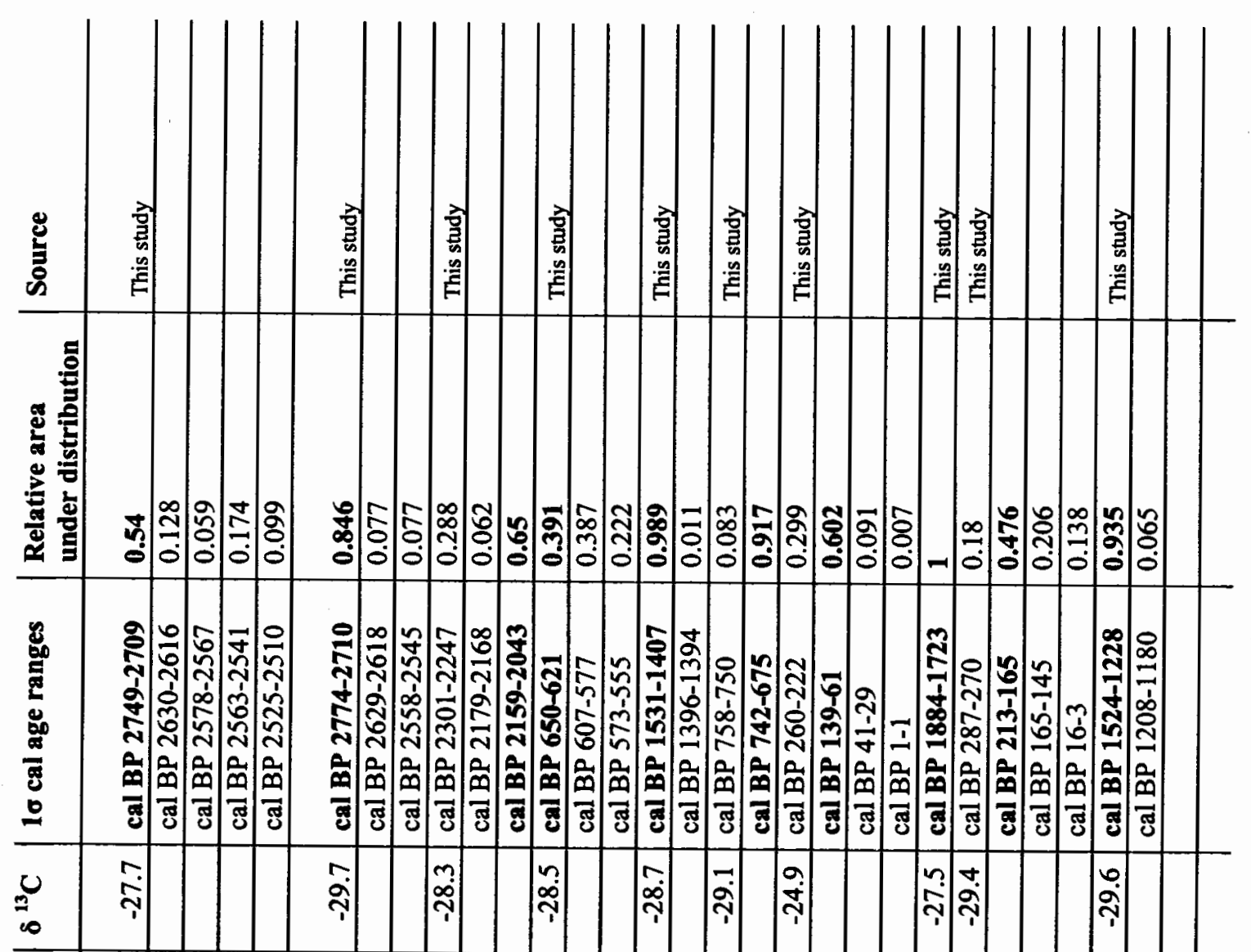

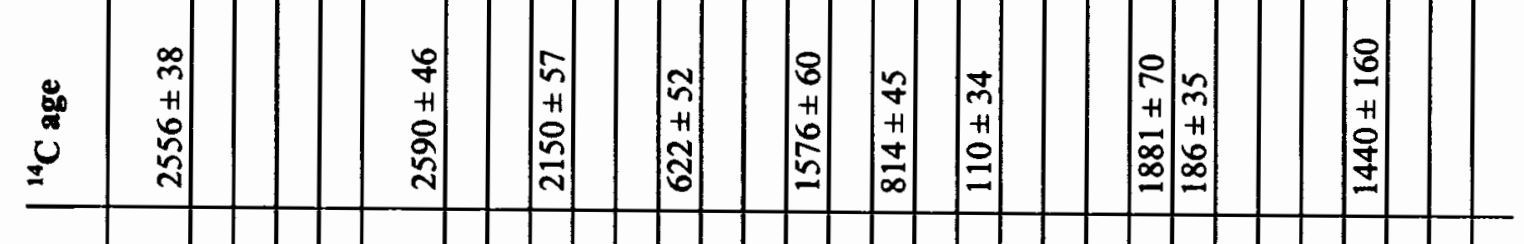

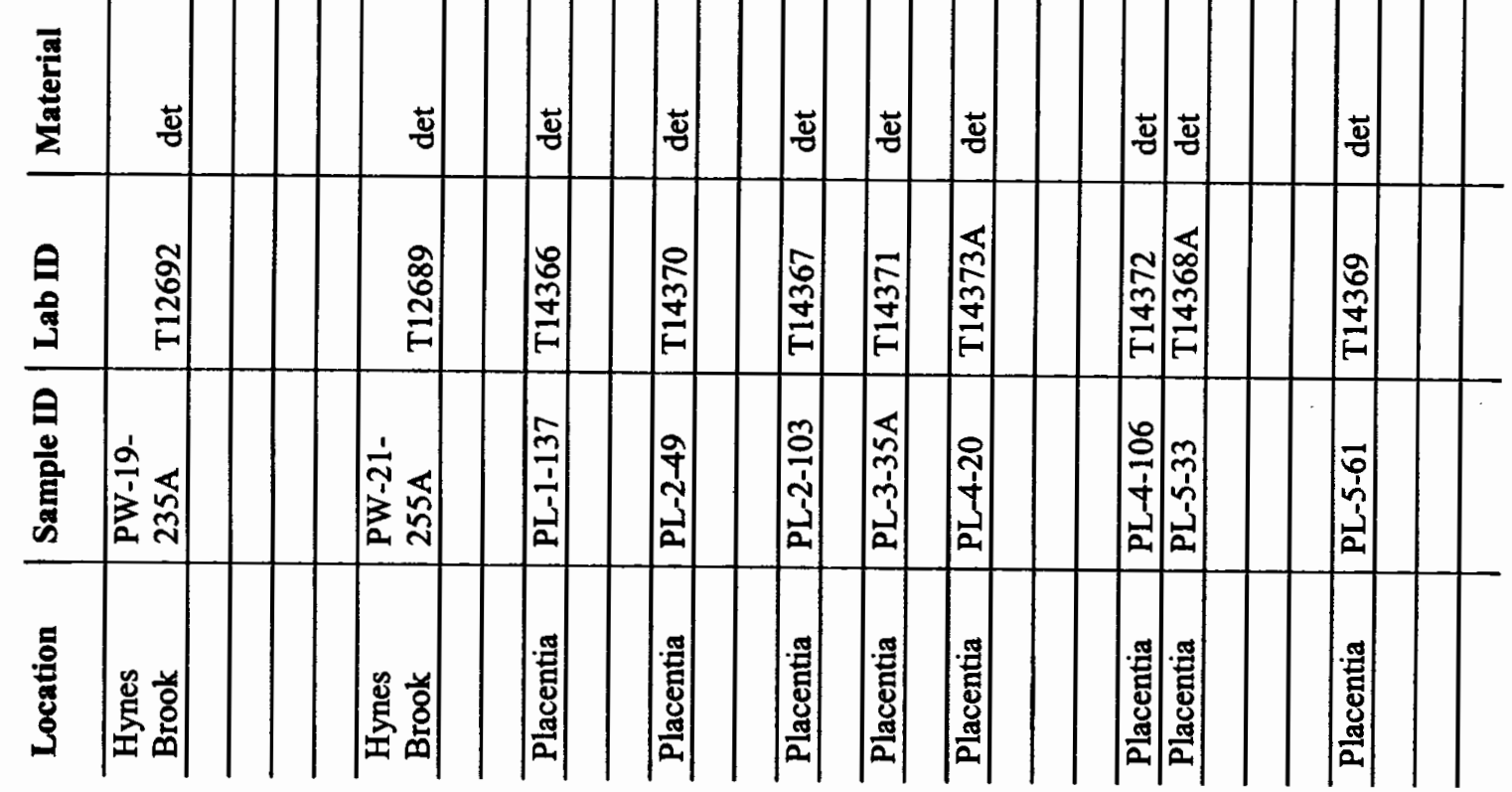




\begin{tabular}{|c|c|c|c|c|c|c|c|c|}
\hline Location & Sample ID & Lab ID & Material & ${ }^{14} \mathrm{C}$ age & $\delta^{13} \mathrm{C}$ & $1 \sigma$ cal age ranges & $\begin{array}{l}\text { Relative area } \\
\text { under distribution }\end{array}$ & Source \\
\hline $\begin{array}{l}\text { St. Paul's } \\
\text { Inlet }\end{array}$ & $\begin{array}{l}\text { SPI-15- } \\
38 \mathrm{~A}\end{array}$ & TO-8745 & Alder & $1910 \pm 100$ & -25 & cal BP 1966-1963 & 0.01 & This study \\
\hline \multirow[t]{2}{*}{$\begin{array}{l}\text { St. Paul's } \\
\text { Inlet } \\
\end{array}$} & $\begin{array}{l}\text { SPI-18- } \\
29 \mathrm{~A} \\
\end{array}$ & TO-8746 & Scirpus & $1190 \pm 120$ & -25 & cal BP 1256-1252 & 0.018 & This study \\
\hline & & & & & & cal BP 1234-1201 & 0.124 & \\
\hline \multirow[t]{3}{*}{$\begin{array}{l}\text { St. Paul's } \\
\text { Inlet } \\
\end{array}$} & SPI-33-27 & & $\operatorname{det}$ & $1240 \pm 140$ & -28.3 & cal BP 1287-1052 & 0.921 & This study \\
\hline & & & & & & cal BP 1029-1066 & 0.073 & \\
\hline & & & & & & cal BP 996-995 & 0.006 & \\
\hline \multirow[t]{2}{*}{$\begin{array}{l}\text { St. Paul's } \\
\text { Inlet }\end{array}$} & SPI-34-42 & $\mathrm{T} 14376$ & det & $376 \pm 40$ & -29 & cal BP $500-430$ & 0.677 & This study \\
\hline & & & & & & cal BP 361-326 & 0.323 & \\
\hline $\begin{array}{l}\text { Deadman's } \\
\text { Bay }\end{array}$ & & & & & & cal BP 23-3 & 0.198 & \\
\hline \multirow[t]{5}{*}{$\begin{array}{l}\text { Deadman's } \\
\text { Bay }\end{array}$} & DB-16-50 & T14377A & det & $1244 \pm 36$ & -11.5 & cal BP $1259-1248$ & 0.084 & This study \\
\hline & & & & & & cal BP 1240-1198 & 0.41 & \\
\hline & & & & & & cal BP $1190-1168$ & 0.214 & \\
\hline & & & & & & cal BP $1160-1136$ & 0.185 & \\
\hline & & & & & & cal BP 1108-1092 & 0.107 & \\
\hline \multirow[t]{4}{*}{$\begin{array}{l}\text { Deadman's } \\
\text { Bay }\end{array}$} & DB-19-95 & $\mathrm{T} 12690$ & det & $170 \pm 65$ & -27.3 & cal BP 289-255 & 0.182 & This study \\
\hline & & & & & & cal BP 225-137 & 0.499 & \\
\hline & & & & & & cal BP 108-74 & 0.145 & \\
\hline & & & & & & cal BP 33-1 & 0.173 & \\
\hline
\end{tabular}




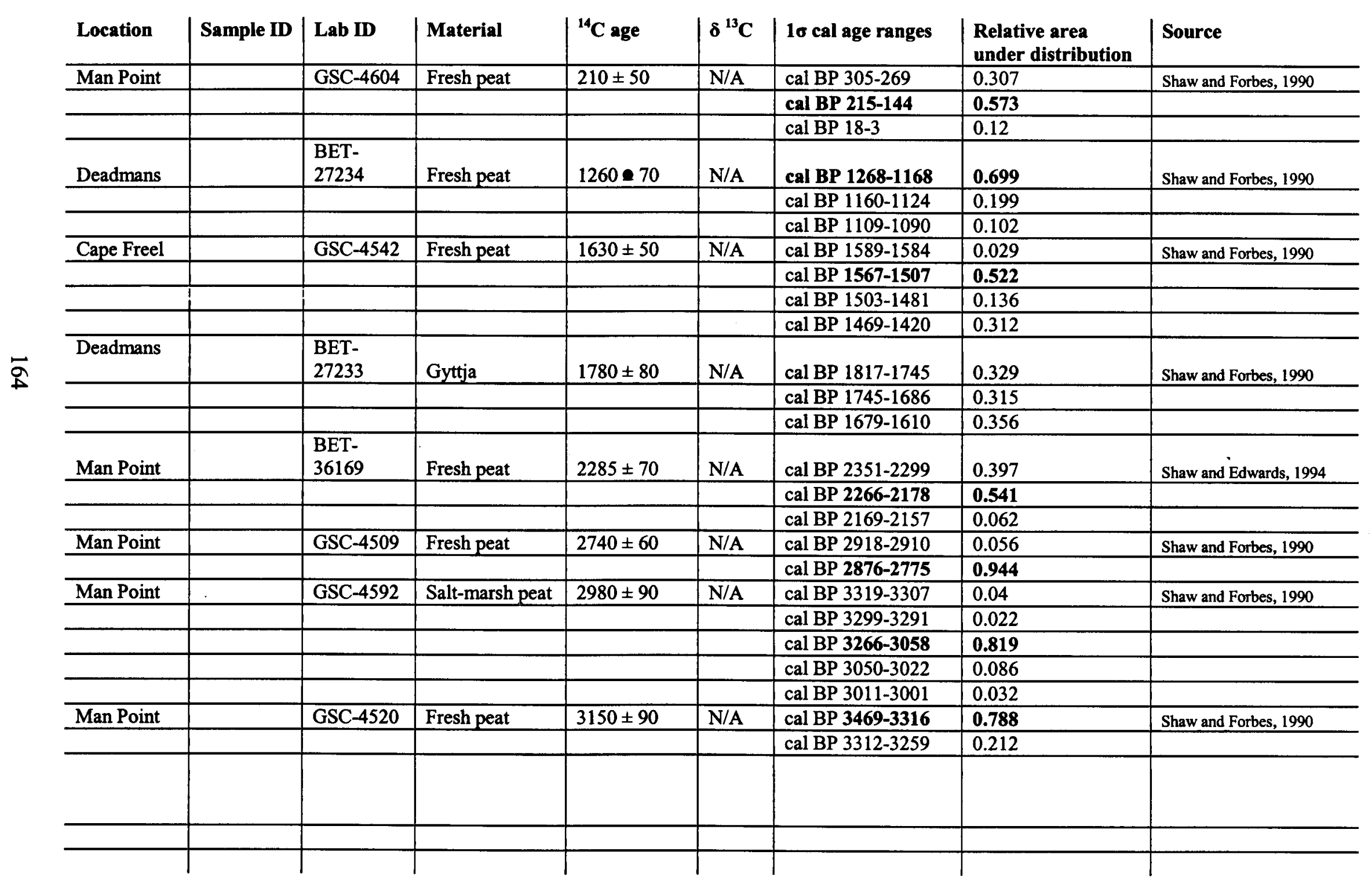




\begin{tabular}{|c|c|c|c|c|c|c|c|c|}
\hline Location & Sample ID & Lab ID & Material & ${ }^{14} \mathrm{C}$ age & $\delta{ }^{13} \mathrm{C}$ & $1 \sigma \mathrm{cal}$ age ranges & $\begin{array}{l}\text { Relative area } \\
\text { under distribution }\end{array}$ & Source \\
\hline \multirow{3}{*}{ Man Point } & & & & & & cal BP 3364-3160 & 0.913 & \\
\hline & & & & & & cal BP 3148-3141 & 0.023 & \\
\hline & & & & & & cal BP $3088-3081$ & 0.02 & \\
\hline Eastport & & $\begin{array}{l}\text { BET- } \\
27231\end{array}$ & Fresh peat & $5490 \pm 120$ & N/A & cal BP 6409-6171 & 0.928 & Shaw and Forbes, 1990 \\
\hline \multirow[t]{3}{*}{ Pound } & & GSC-4882 & Wood & $8140 \pm 80$ & N/A & cal BP 9252-9215 & 0.159 & Shaw and Edwards, 1994 \\
\hline & & & & & & cal BP 9212-9171 & 0.159 & \\
\hline & & & & & & cal BP 9136-9006 & 0.683 & \\
\hline \multirow[t]{3}{*}{ Hamilton } & & $\begin{array}{l}\text { BET- } \\
51675 \\
\end{array}$ & Shell & $8630 \pm 140$ & N/A & cal BP 9888-9879 & 0.02 & Shaw and Edwards, 1994 \\
\hline & & & & & & cal BP 9867-9847 & 0.047 & \\
\hline & & & & & & cal BP 9822-9807 & 0.033 & \\
\hline \multirow{4}{*}{ Hamilton } & & & & & & cal BP 10596-10588 & 0.019 & \\
\hline & & & & & & cal BP 10538-10358 & 0.653 & \\
\hline & & & & & & cal BP 10348-10324 & 0.061 & \\
\hline & & & & & & cal BP 10324-10248 & 0.187 & \\
\hline \multirow[t]{4}{*}{ Freemans } & & GSC-3973 & Gyttja & $11000 \pm 260$ & N/A & cal BP 13340-13245 & 0.11 & Blake, 1987 \\
\hline & & & & & & cal BP 13205-12812 & 0.815 & \\
\hline & & & & & & cal BP $12724-12660$ & 0.075 & \\
\hline & & & & & & & & \\
\hline
\end{tabular}




\begin{tabular}{|c|c|c|c|c|c|c|c|c|}
\hline Location & Sample ID & Lab ID & Material & ${ }^{14} \mathrm{C}$ age & $\delta^{13} \mathrm{C}$ & $1 \sigma \mathrm{cal}$ age ranges & $\begin{array}{l}\text { Relative area } \\
\text { under distribution }\end{array}$ & Source \\
\hline \multirow[t]{6}{*}{ Newtown } & & WAT-888 & Wood & $10290 \pm 380$ & N/A & cal BP 12776-12755 & 0.015 & Davis and Wickham, 1987 \\
\hline & & & & & & cal BP 12633-11550 & 0.924 & \\
\hline & & & & & & cal BP $11502-11486$ & 0.008 & \\
\hline & & & & & & cal BP 11471-11436 & 0.023 & \\
\hline & & & & & & cal BP 11428-11421 & 0.007 & \\
\hline & & & & & & cal BP 11385-11358 & 0.022 & \\
\hline \multirow[t]{2}{*}{ Parsons } & & GSC-4182 & Shell & $12000 \pm 240$ & N/A & cal BP 14913-14881 & 0.018 & Shaw and Forbes, 1990 \\
\hline & & & & & & cal BP 14334-13504 & 0.982 & \\
\hline \multirow[t]{2}{*}{ Hamilton } & & $\begin{array}{l}\text { BET- } \\
51677\end{array}$ & Shell & $11620 \pm 100$ & N/A & cal BP 13813-13746 & 0.197 & Shaw and Edwards, 1994 \\
\hline & & & & & & cal BP 13685-13447 & 0.803 & \\
\hline \multirow[t]{2}{*}{ Exploits } & & $\begin{array}{l}\text { BET- } \\
51672\end{array}$ & Shell & $12020 \pm 100$ & N/A & cal BP $14244-14223$ & 0.03 & Shaw and Forbes, 1990 \\
\hline & & & & & & cal BP 14144-13824 & 0.97 & \\
\hline St. George & & GSC-1145 & Org. det. - bog & $7340 \pm 220$ & NA & 8358-7959 & 1 & \\
\hline \multirow[t]{5}{*}{ St. George } & & WAT- 883 & Org. det. - bog & $9350 \bullet 120$ & NA & $10730-10714$ & 0.039 & \\
\hline & & & & & & 10698-10388 & 0.904 & \\
\hline & & & & & & $10337-10336$ & 0.019 & \\
\hline & & & & & & $10317-10315$ & 0.019 & \\
\hline & & & & & & $10300-10291$ & 0.02 & \\
\hline \multirow[t]{3}{*}{ Hynes Bk. } & A & GX-9527 & $\begin{array}{l}\text { Basal salt } \\
\text { marsh peat }\end{array}$ & $2365 \pm 175$ & NA & $2711-2624$ & 0.181 & Brookes et al., 1985 \\
\hline & & & & & & $2621-2303$ & 0.7 & \\
\hline & & & & & & $2240-2181$ & 0.119 & \\
\hline \multirow[t]{3}{*}{ Hynes Bk. } & B & UQ-646 & Basal SM peat & $2770 \pm 300$ & NA & $3324-3287$ & 0.041 & Brookes et al., 1985 \\
\hline & & & & & & $3267-2703$ & 0.799 & \\
\hline & & & & & & $2640-2492$ & 0.159 & \\
\hline $\begin{array}{l}\text { Robinson's } \\
\text { Head }\end{array}$ & & GSC-1200 & Shell & $13500 \pm 210$ & NA & $16563-15863$ & 1.0 & \\
\hline
\end{tabular}


Appendix D

CORE LOGS 
CORE \#: PW-18

Date: $7-5-99$

Location: Hynes Brook

Site Description: Freshwater transition

MHW elev: $0.36 \mathrm{~m}$

Length: $2.37 \mathrm{~m}$

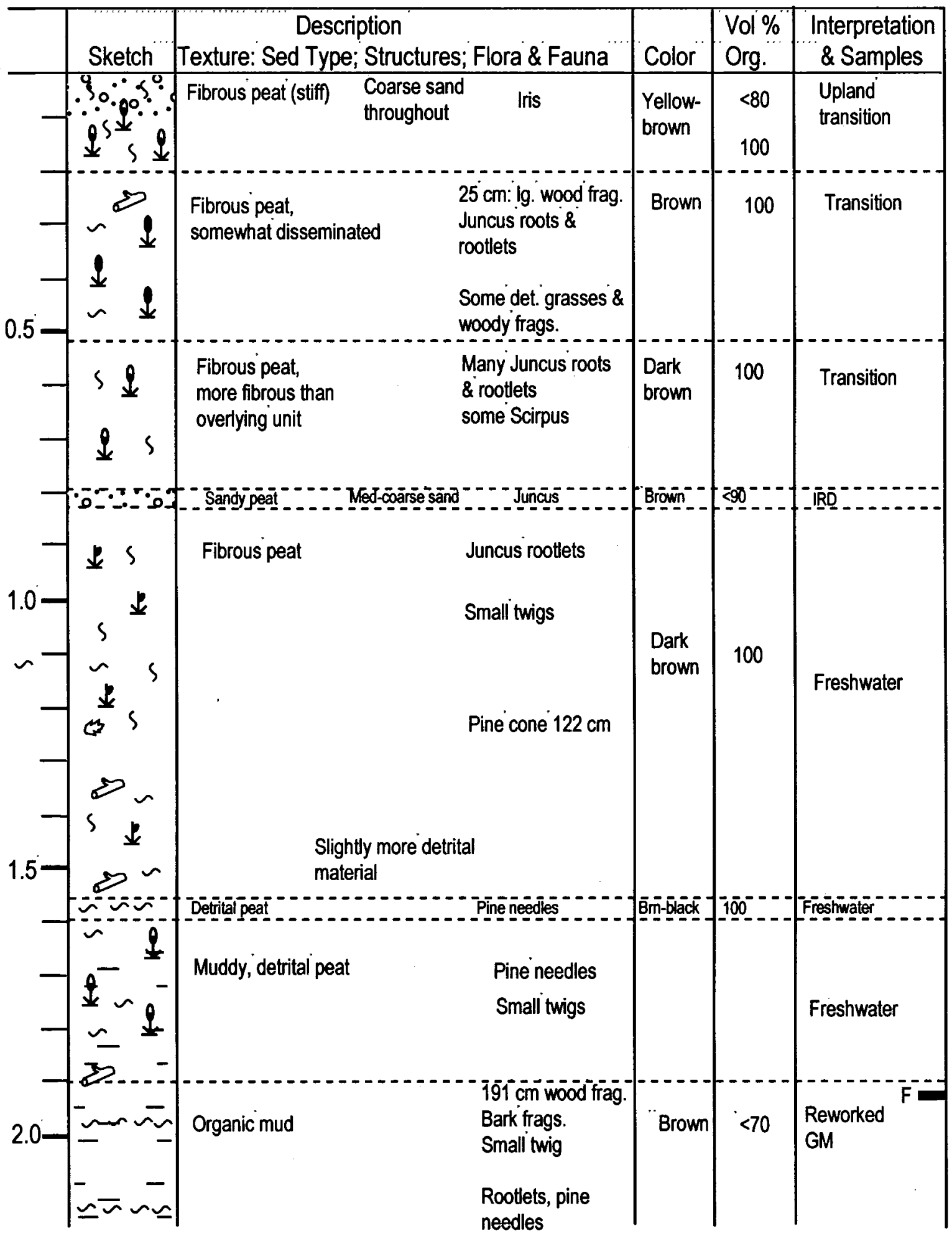


CORE \#: PW-19

Date: $7-5-99$

Location: Hynes Brook

Site Description: High marsh

Elev: $0.31 \mathrm{~m}$

Length: $2.95 \mathrm{~m}$

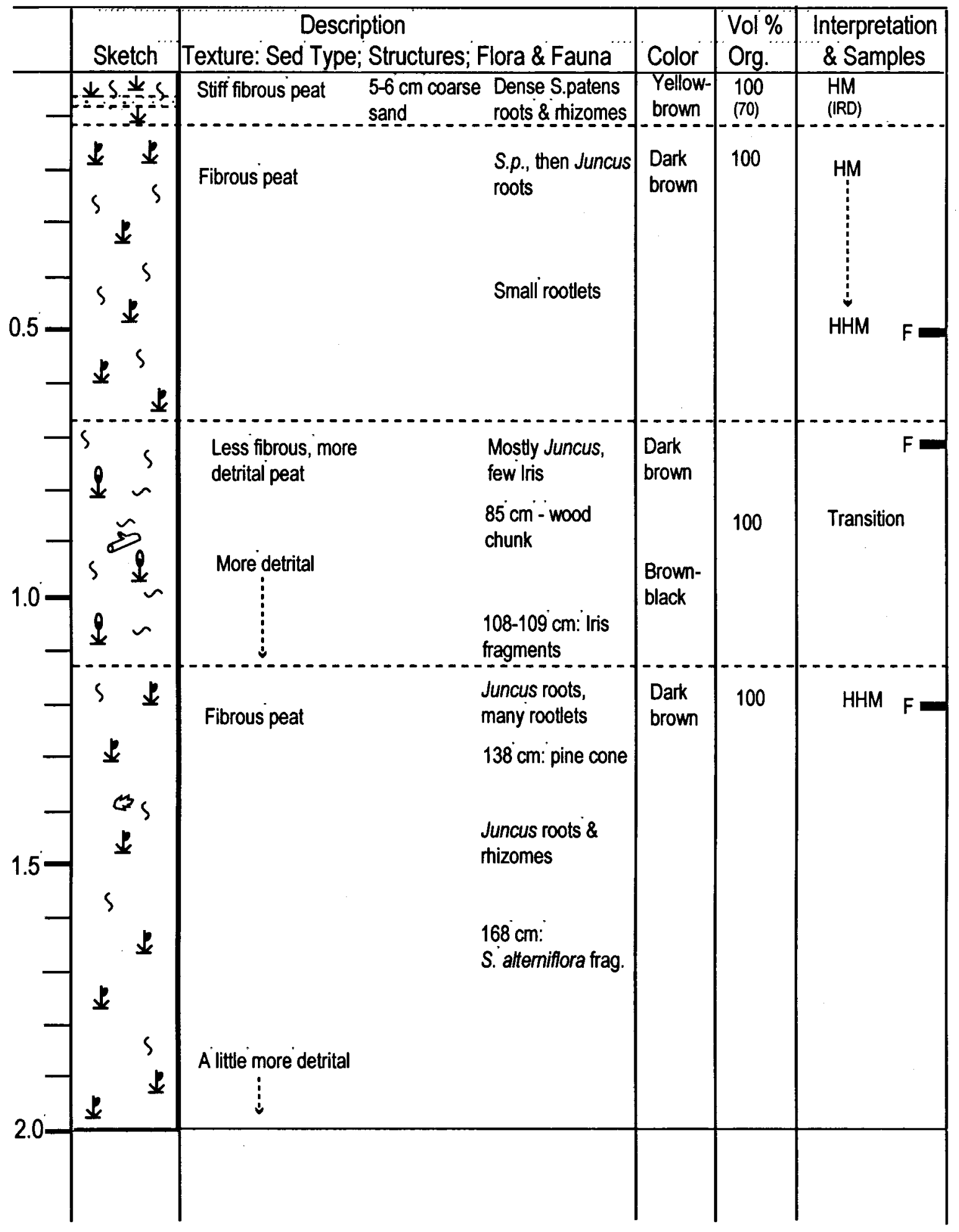


CORE \#:PW-19, page 2

Date: $7-5-99$

Location: Hynes Brook

Site Description: High marsh

Elev: $0.31 \mathrm{~m}$

Length: $2.95 \mathrm{~m}$

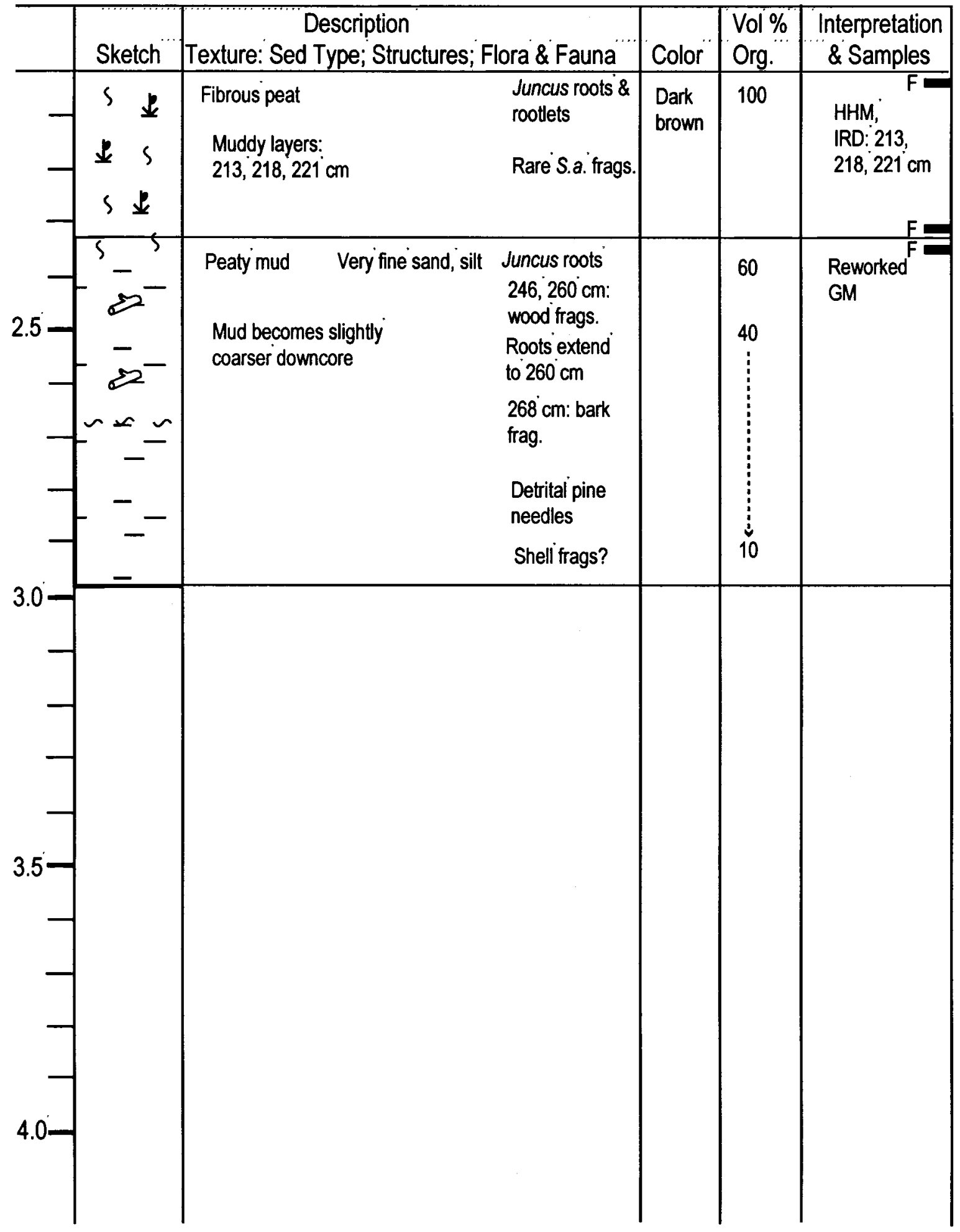


CORE \#: PW-20

Date: $7-5-99$

Location: Hynes Brook

Site Description: Higher high marsh

MHW elev: $0.397 \mathrm{~m} \quad$ Length: $2.07 \mathrm{~m}$

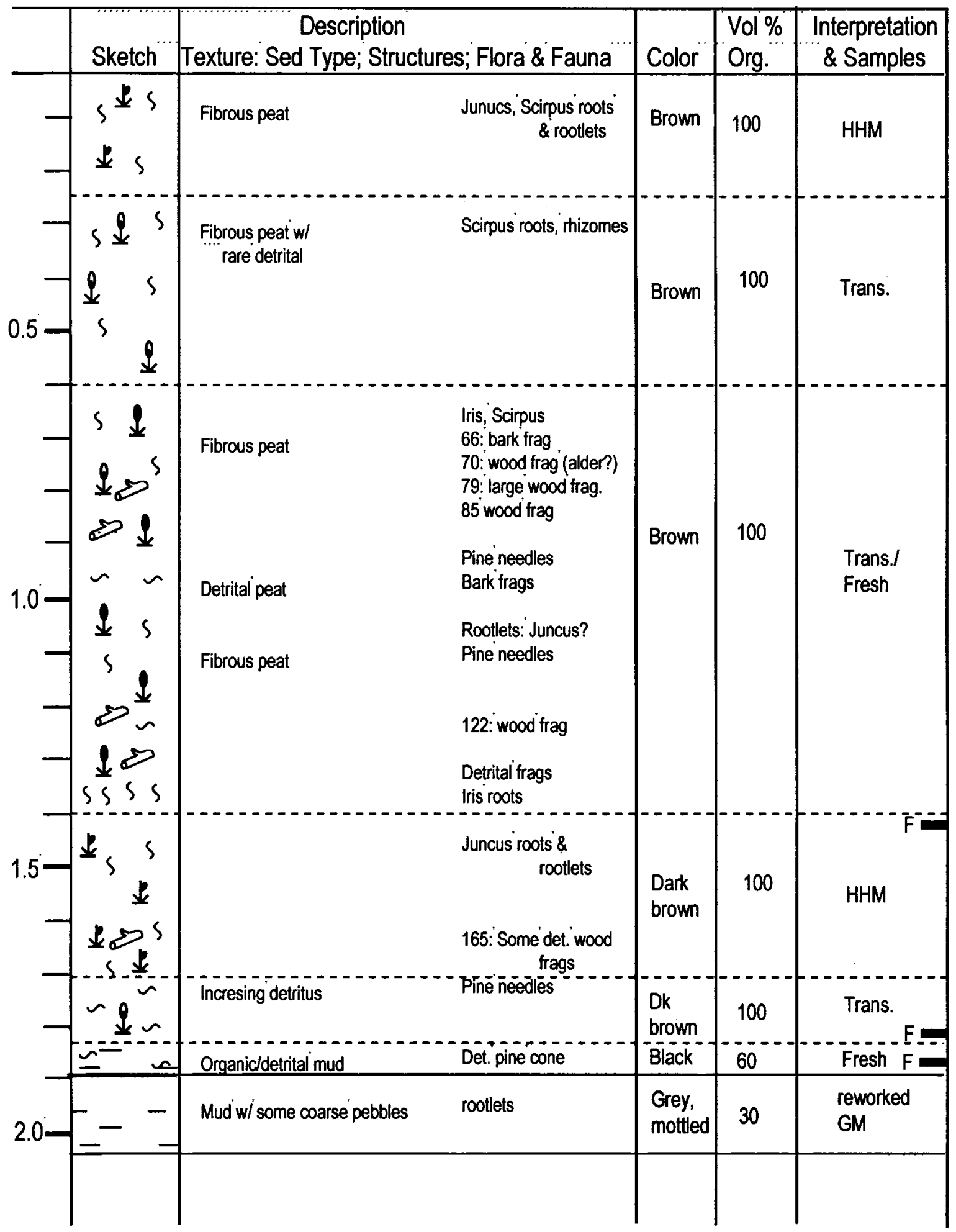


CORE \#: PW-21

Date: $7-5-99$

Location: Hynes Brook

Site Description: High marsh

Elev: $0.35 \mathrm{~m} \quad$ Length: $2.68 \mathrm{~m}$

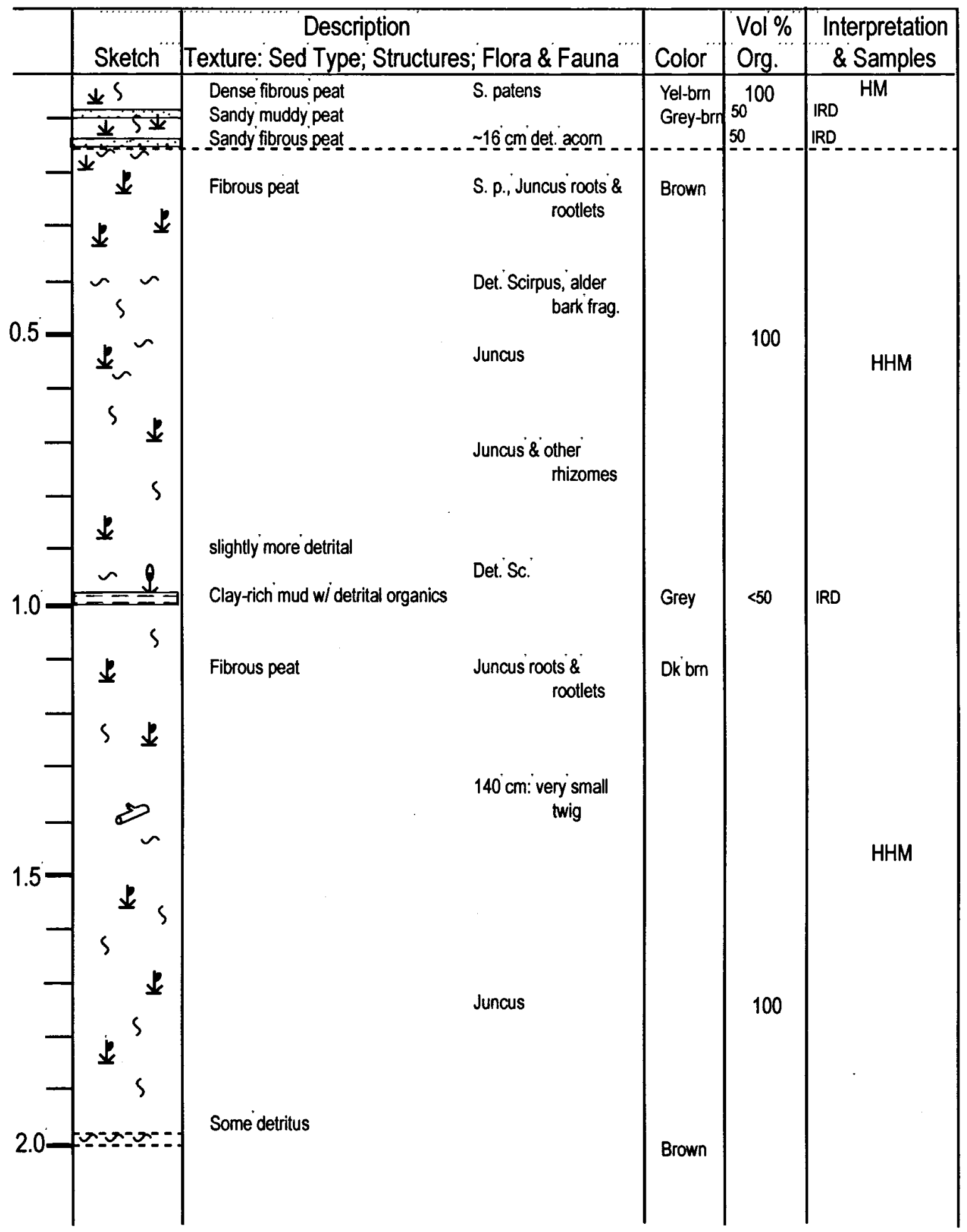


CORE \#: PW-21, page 2

Date: 7-5-99 Location: Hynes Brook

Site Description: Higher high marsh

Elev: $0.35 \mathrm{~m}$ Length: $2.68 \mathrm{~m}$

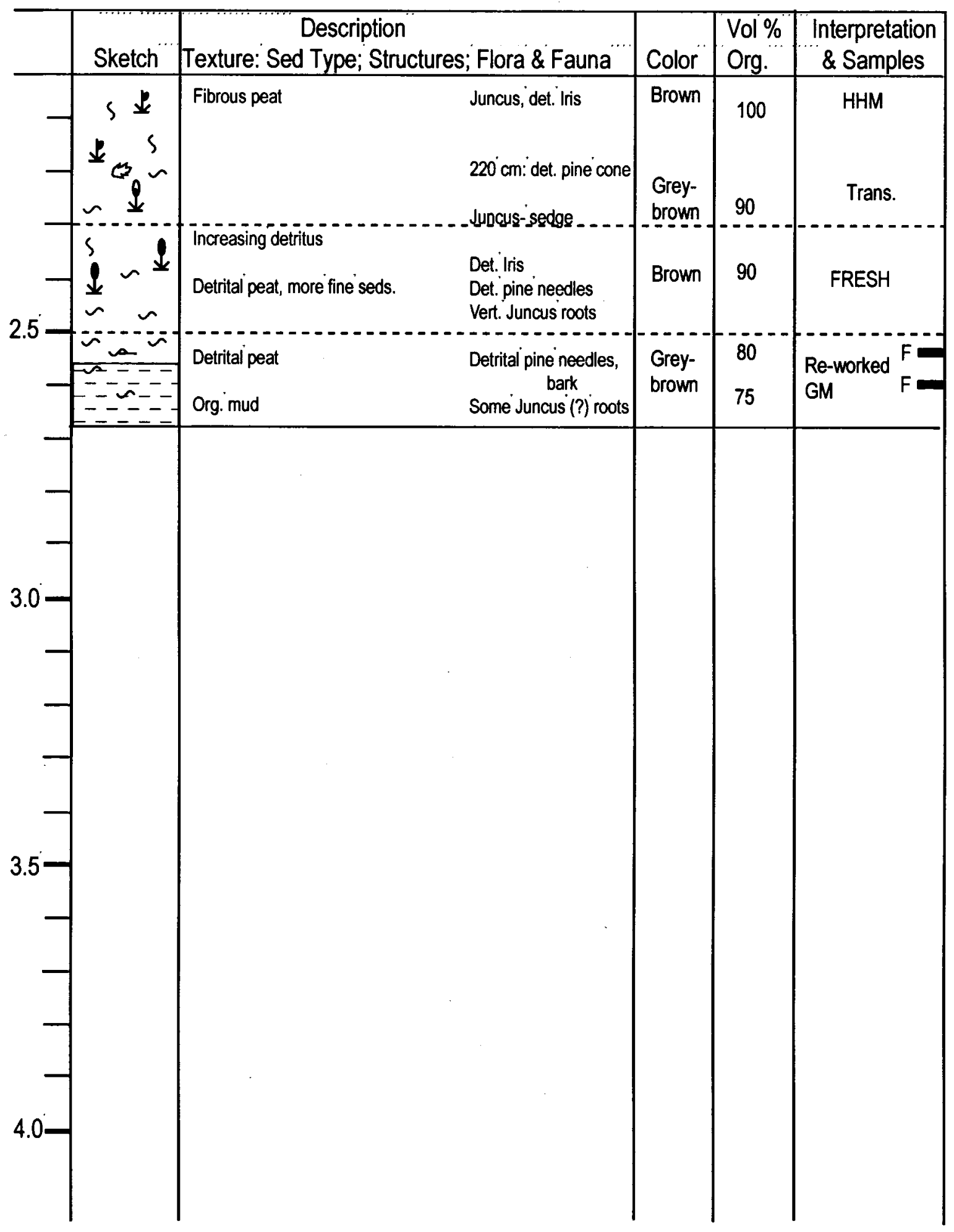


CORE \#: PW-22

Date: 7-5-99

Location: Hynes Brook, east transect

Site Description: Higher high marsh

Elev: $0.54 \mathrm{~m}$ Length: $0.94 \mathrm{~m}$

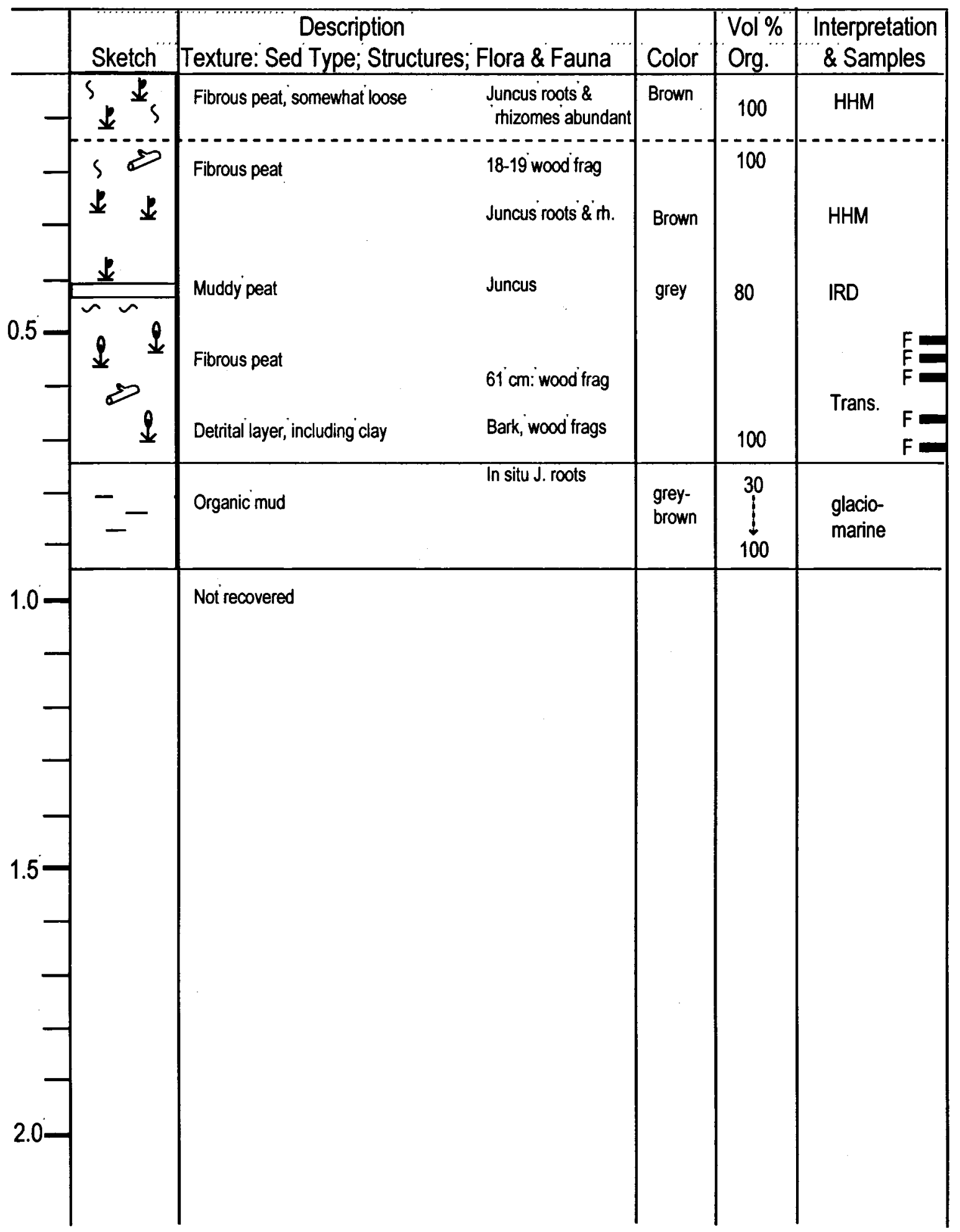


CORE \#: PW-23

Location: Hynes Brook, east transect

Date: $7-5-99$

Site Description: High marsh

Elev: $0.46 \mathrm{~m}$ Length: $1.0 \mathrm{~m}$

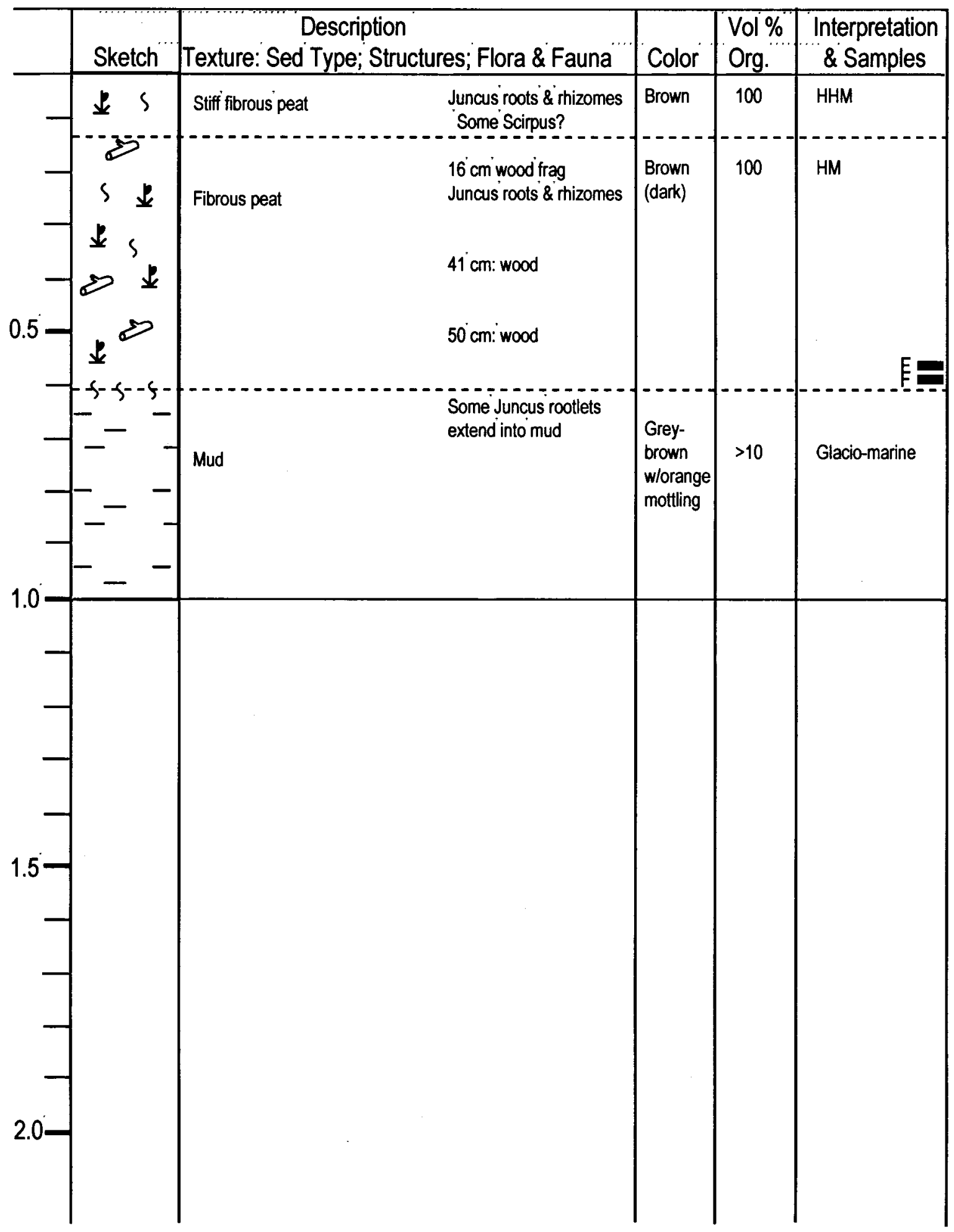


CORE \#: PW-24

Date: 7-5-99

Location: Hynes Brook, west transect

Site Description: High marsh

MHW elev: $0.38 \mathrm{~m}$

Length: $1.41 \mathrm{~m}$

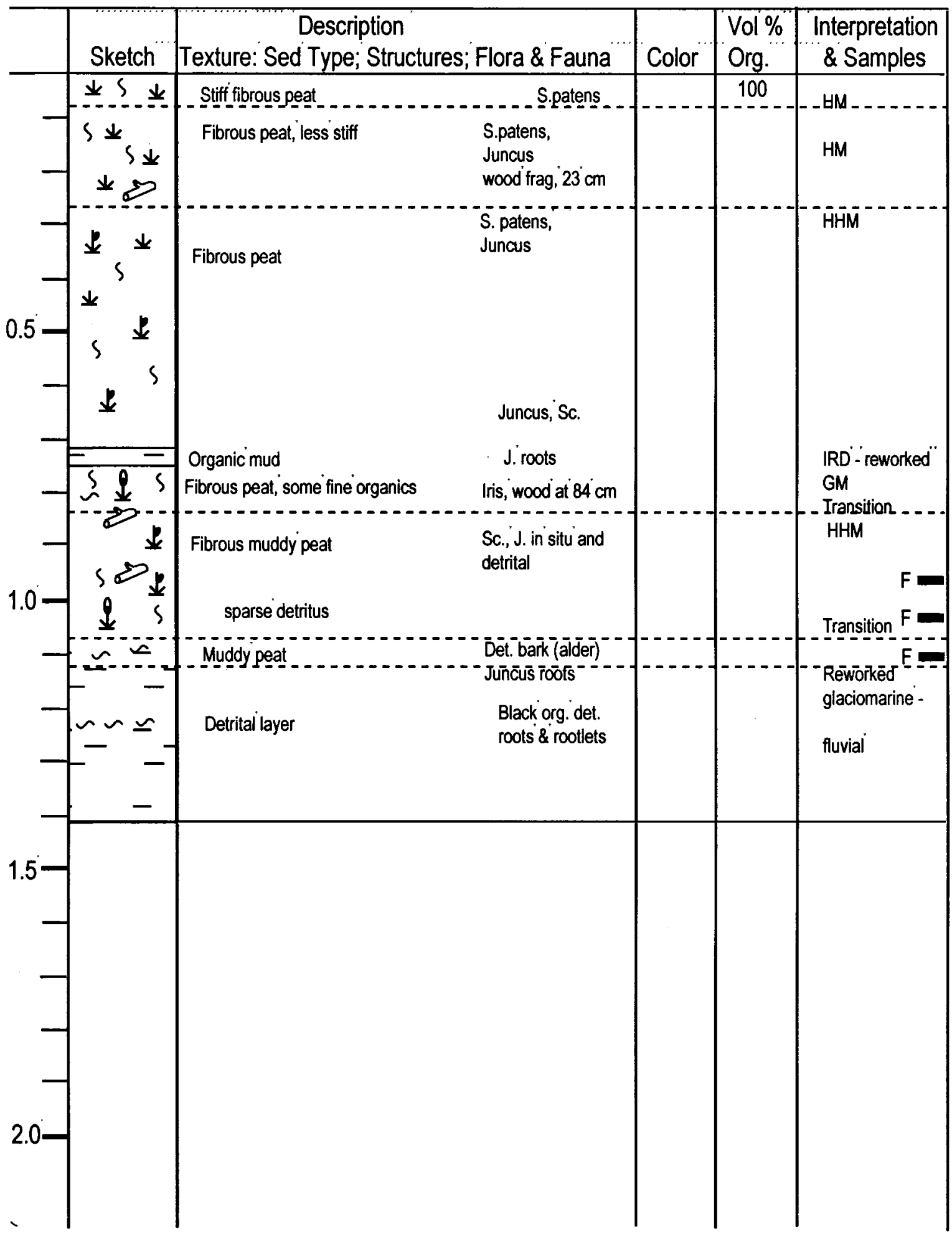


CORE \#: PW-25

Location: Hynes Brook, south transect

Date: $7-5-99$

Site Description: High marsh

MHW elev: $0.36 \mathrm{~m} \quad$ Length: $1.81 \mathrm{~m}$

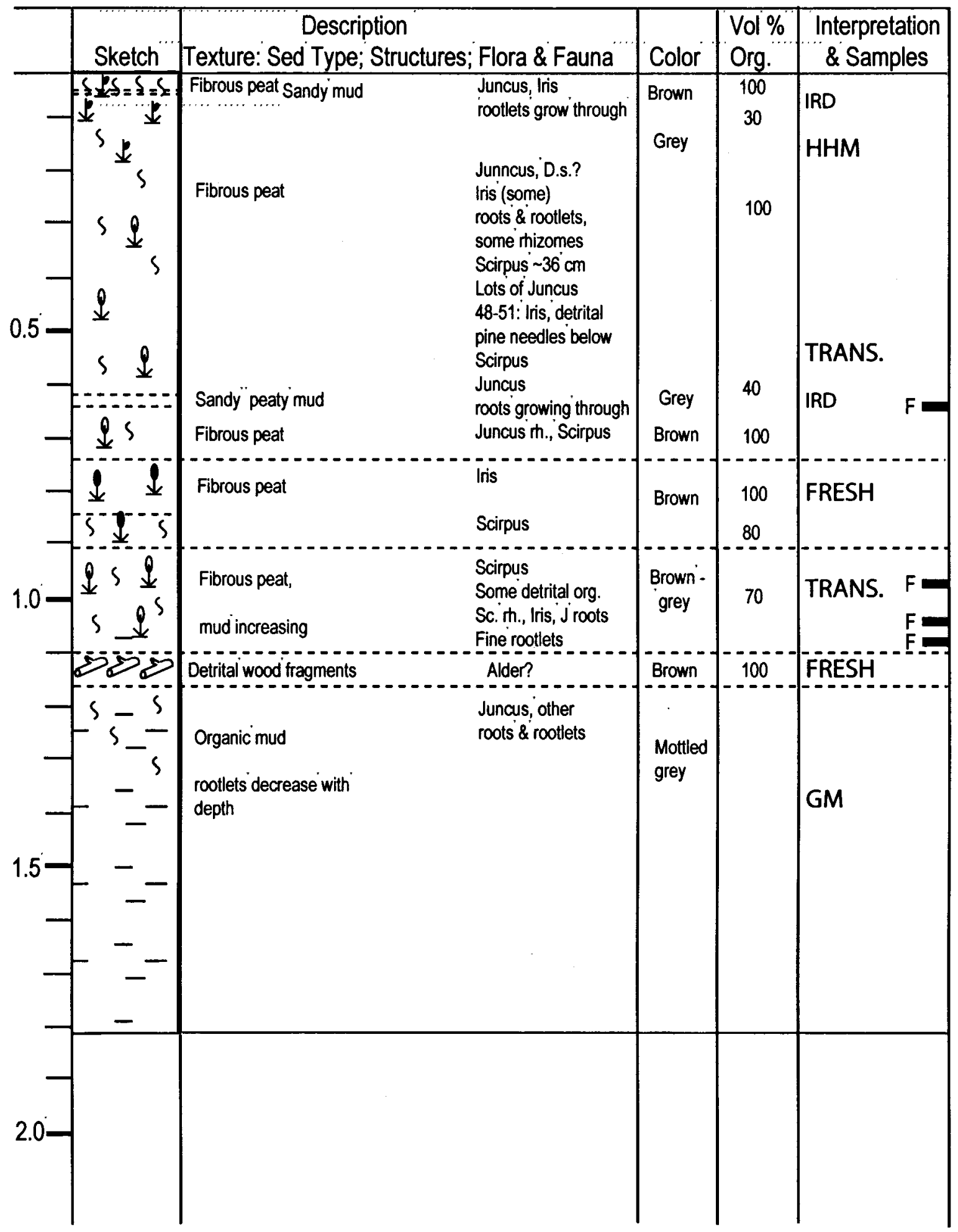


CORE \#: SPI-13

Date: $7-12-99$

Location: St. Paul's Inlet, bog transect

Site Description: upland forest

MHW elev: $1.25 \mathrm{~m}$

Length: $0.75 \mathrm{~m}$

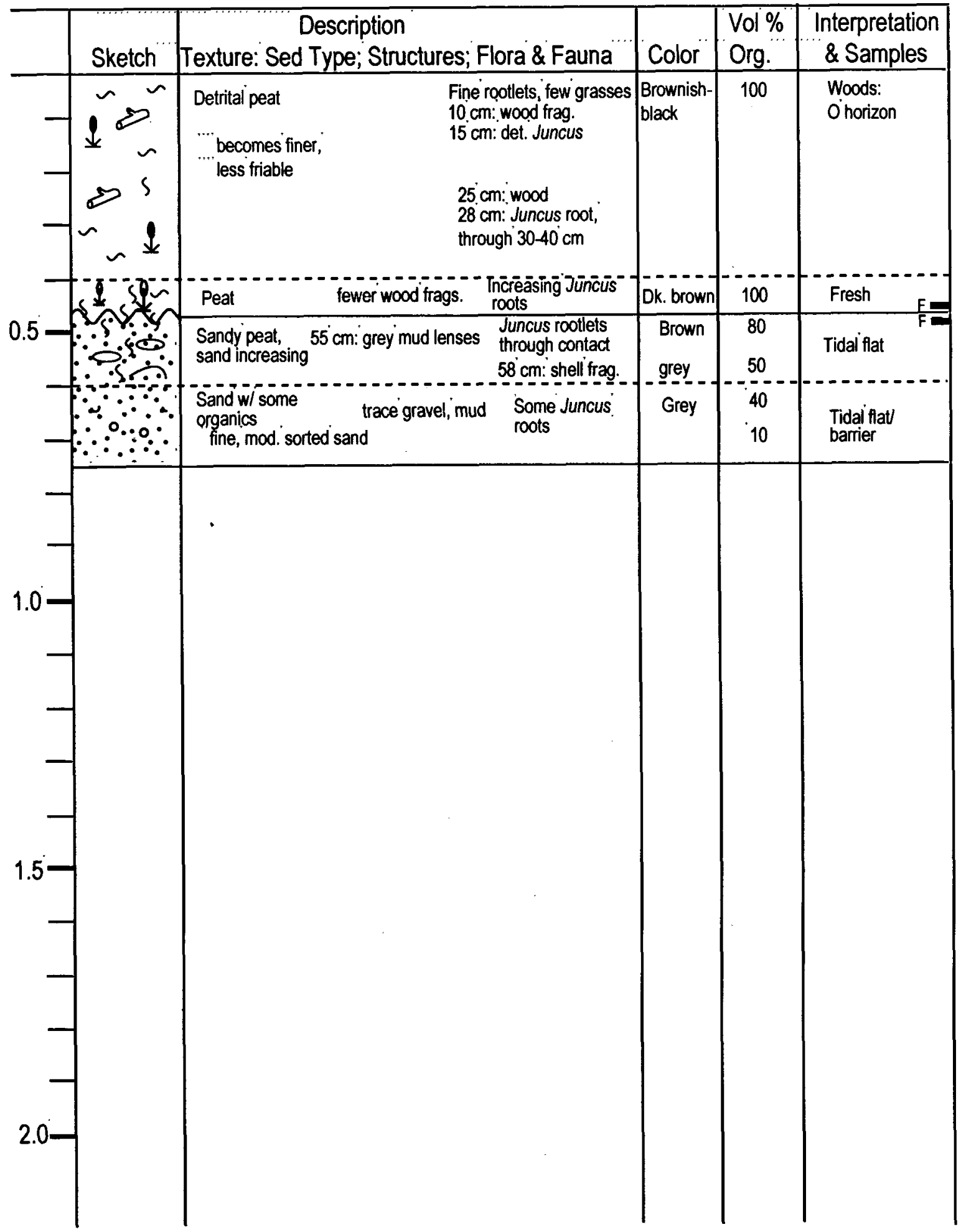


CORE \#: SPI-14

Date: $7-12-99$

Location: St. Paul's Inlet, bog transect

Site Description: Alder zone

MHW elev: $1.38 \mathrm{~m}$ Length: $0.82 \mathrm{~m}$

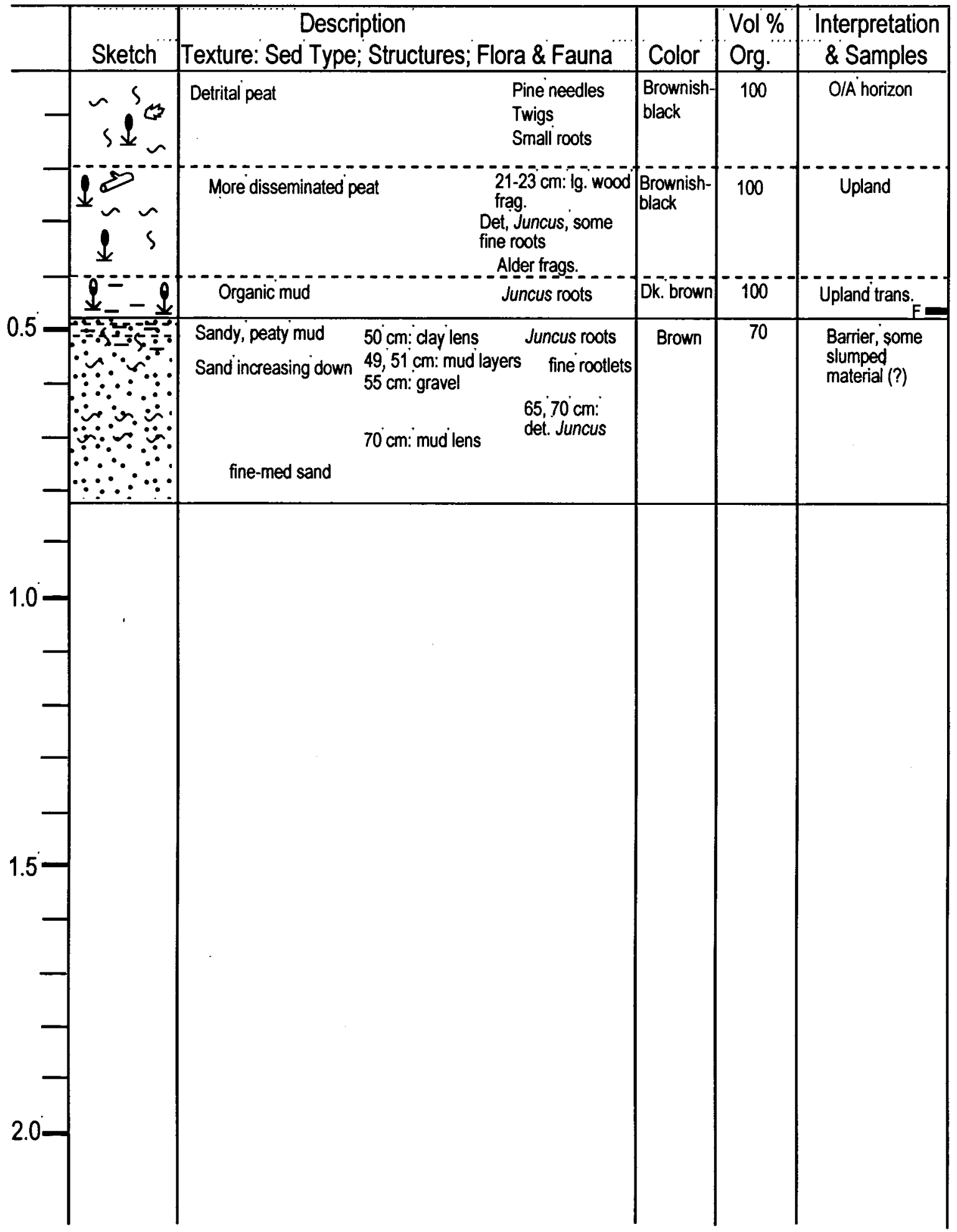


CORE \#: SPI-15

Date: $7-12-99$

Location: St. Paul's Inlet, bog transect

Site Description: Alder zone

MHW elev: $1.15 \mathrm{~m} \quad$ Length: $0.63 \mathrm{~m}$

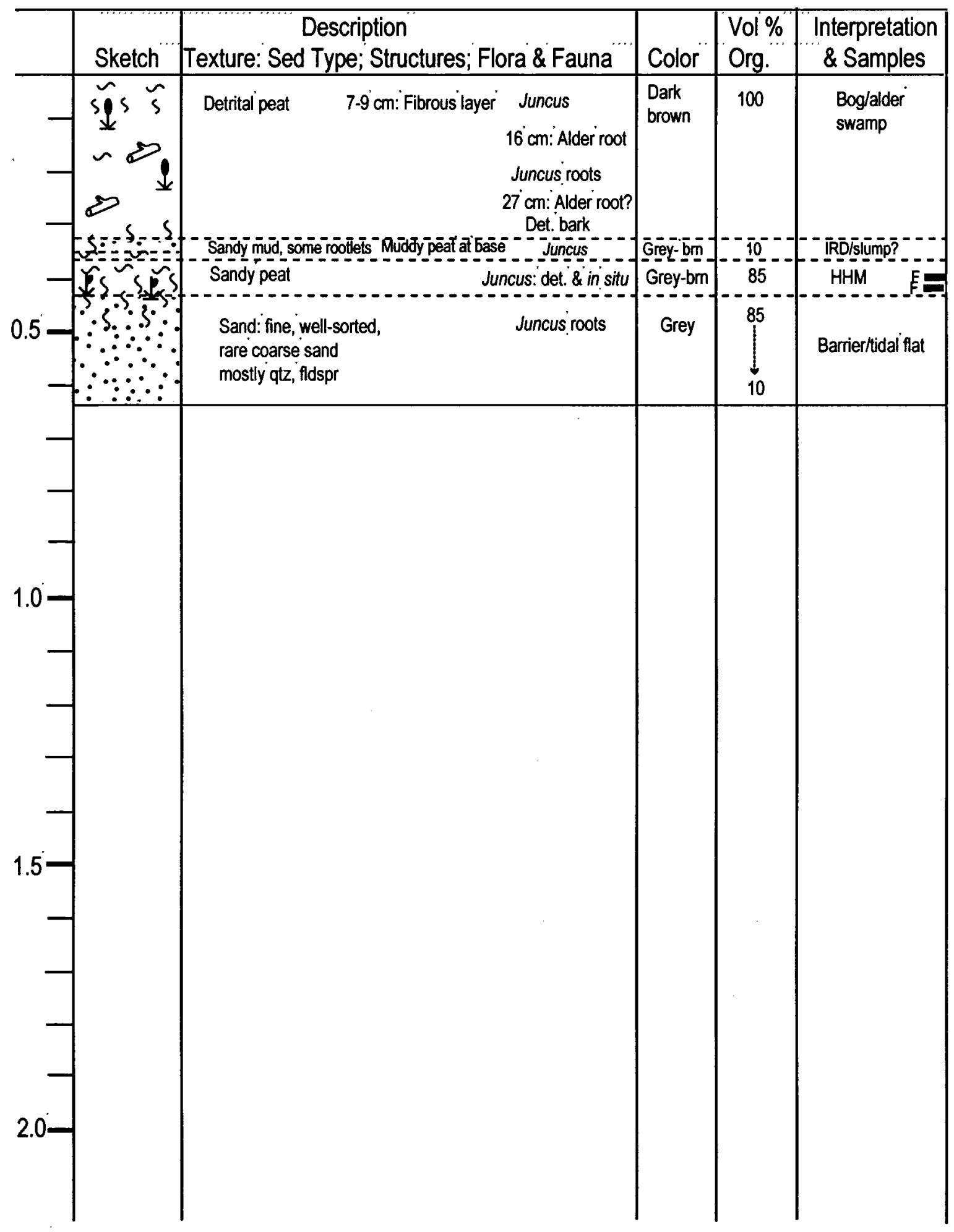


CORE \#: SPI-16

Date: $7-12-99$

Location: St. Paul's Inlet, bog transect

Site Description: Alders/bog transition

MHW elev: $0.19 \mathrm{~m}$ "Length: $0.60 \mathrm{~m}$

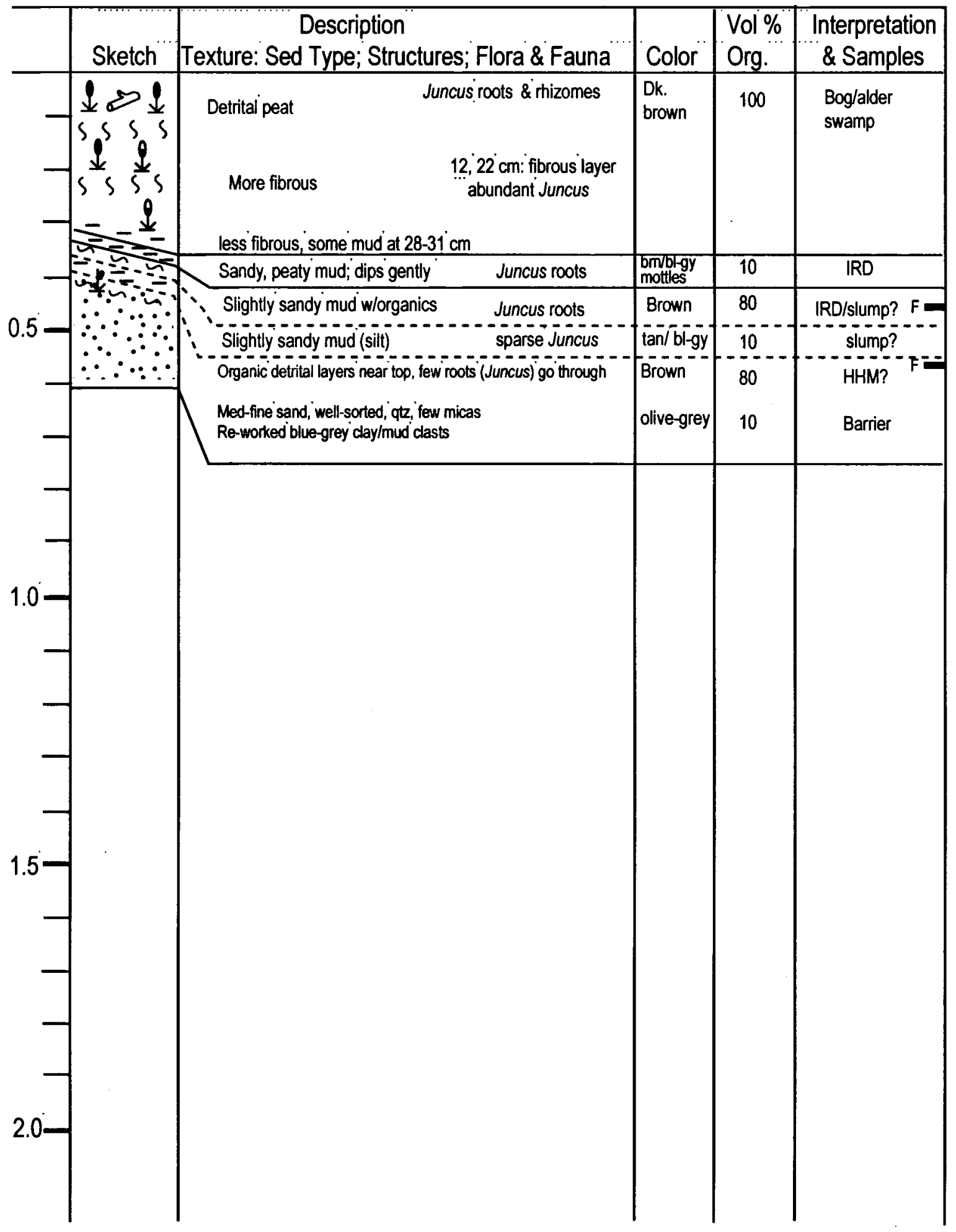


CORE \#: SPI-17

Date: $7-12-99$

Location:St. Paul's inlet, bog transect

Site Description: Bog

MHW elev: $0.37 \mathrm{~m}$

Length: $0.55 \mathrm{~m}$

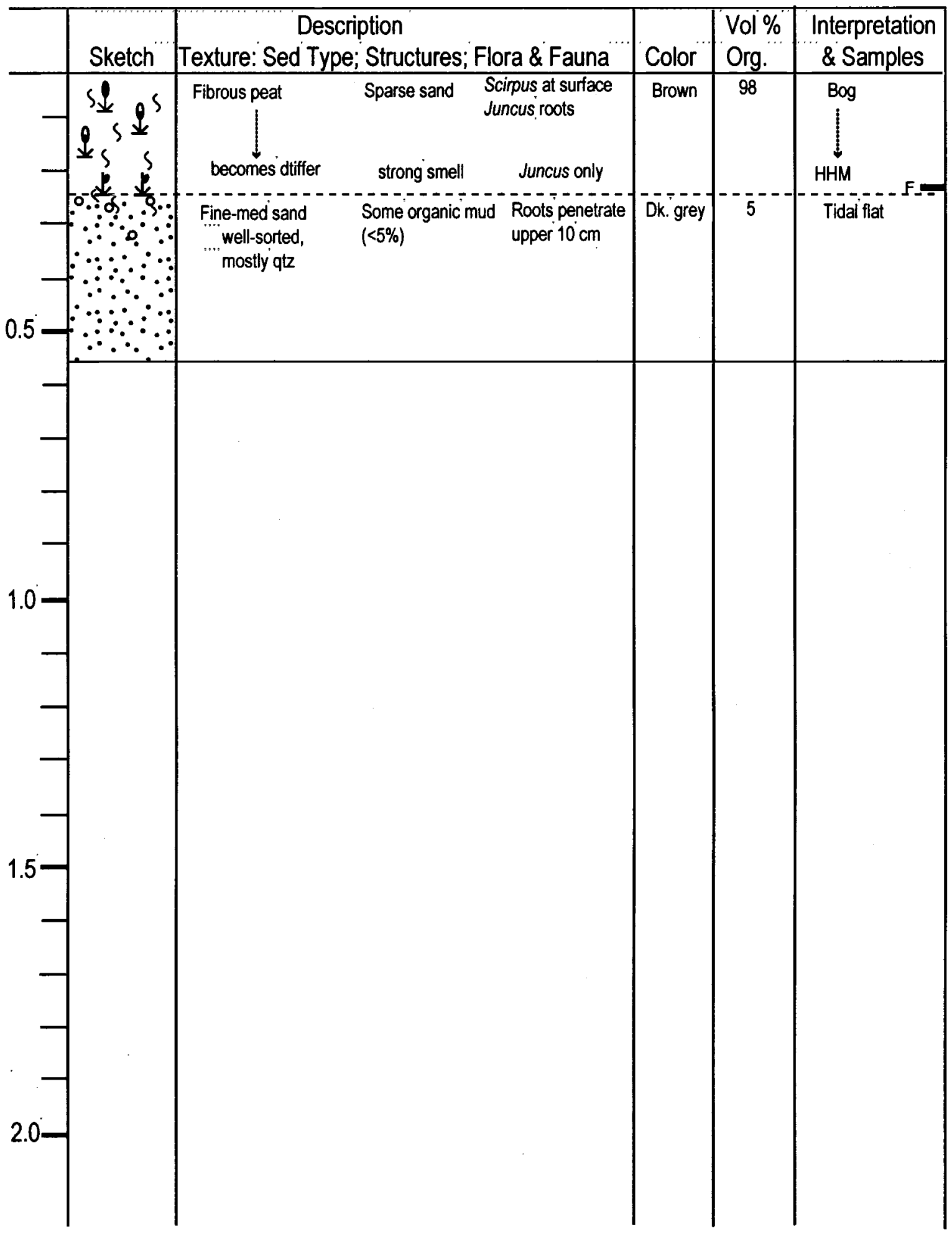


CORE \#: SPI-18

Date: $7-12-99$

Location: St. Paul's Inlet, barrier transect

Site Description: HM

MHW elev: $0.58 \mathrm{~m} \quad$ Length: $0.45 \mathrm{~m}$

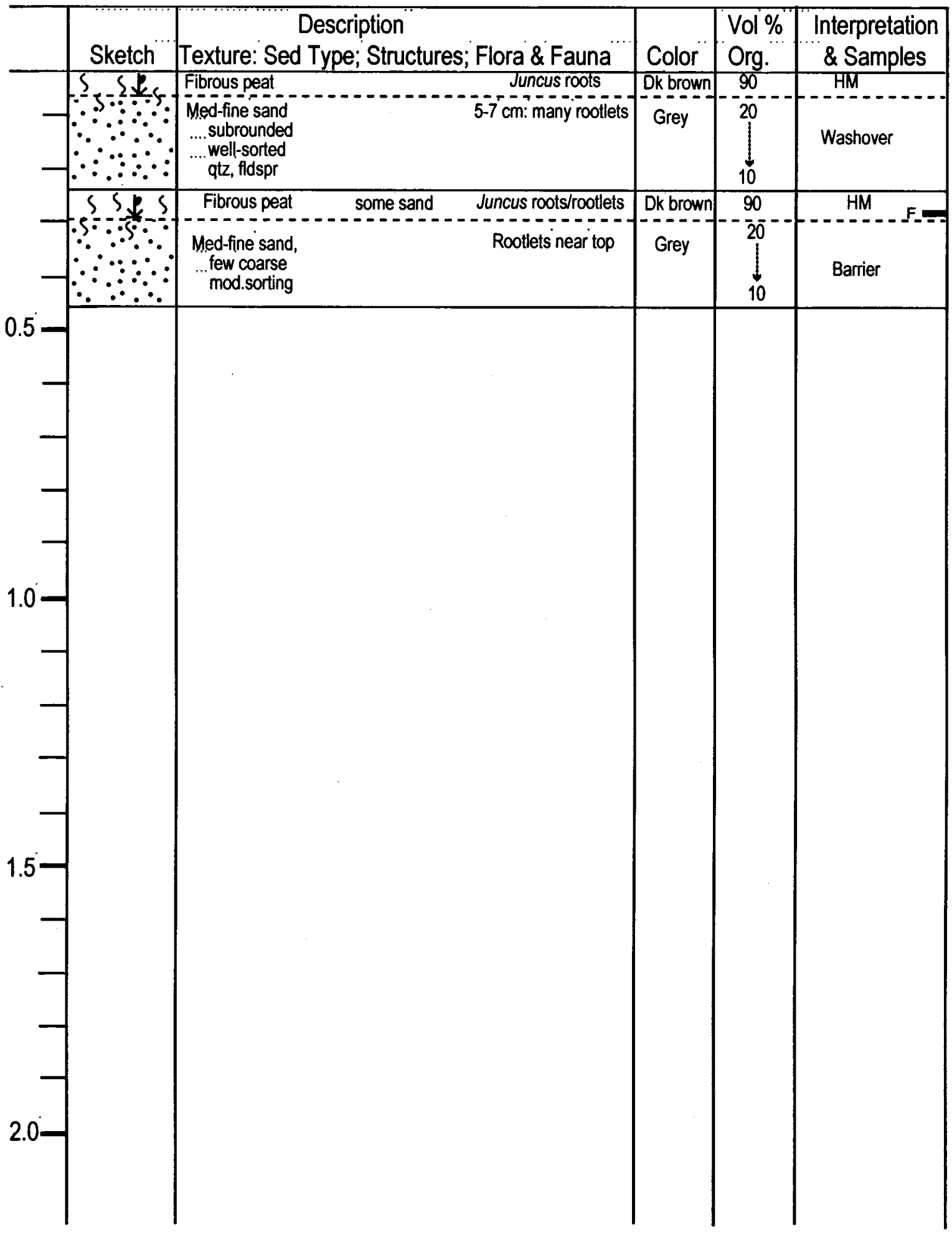


CORE \#: SPI-19

Date: $7-12-99$

Location: St. Pauls' Inlet, barrier transect

Site Description: HM

MHW elev: $0.50 \mathrm{~m} \quad$ Length: $0.40 \mathrm{~m}$

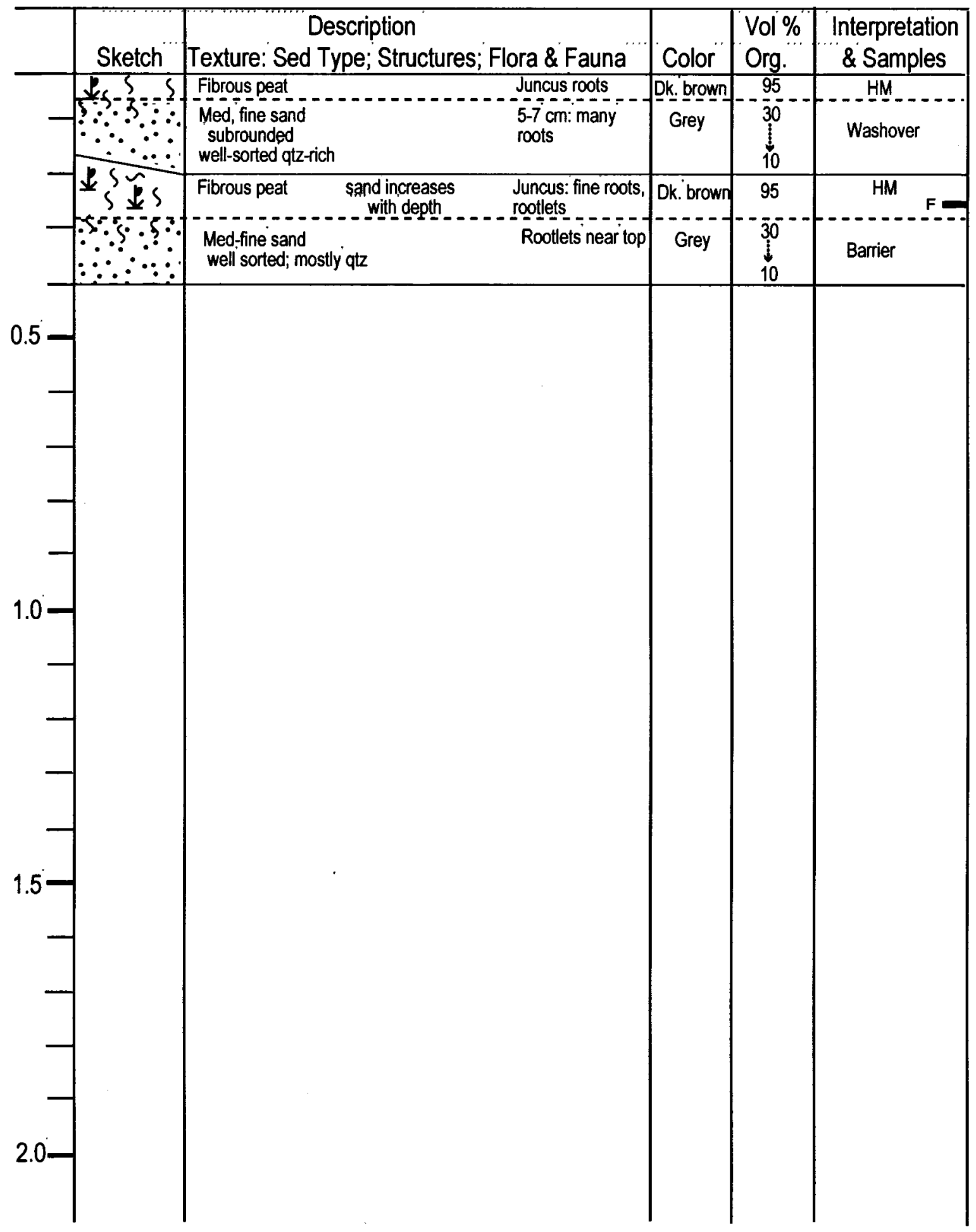


CORE \#: SPI-30

Date: $7-20-99$

Location: St. Paul's Inlet, barrier transect

Site Description: HHM/upland transition

MHW elev: $0.58 \mathrm{~m}$ Length: $0.45 \mathrm{~m}$

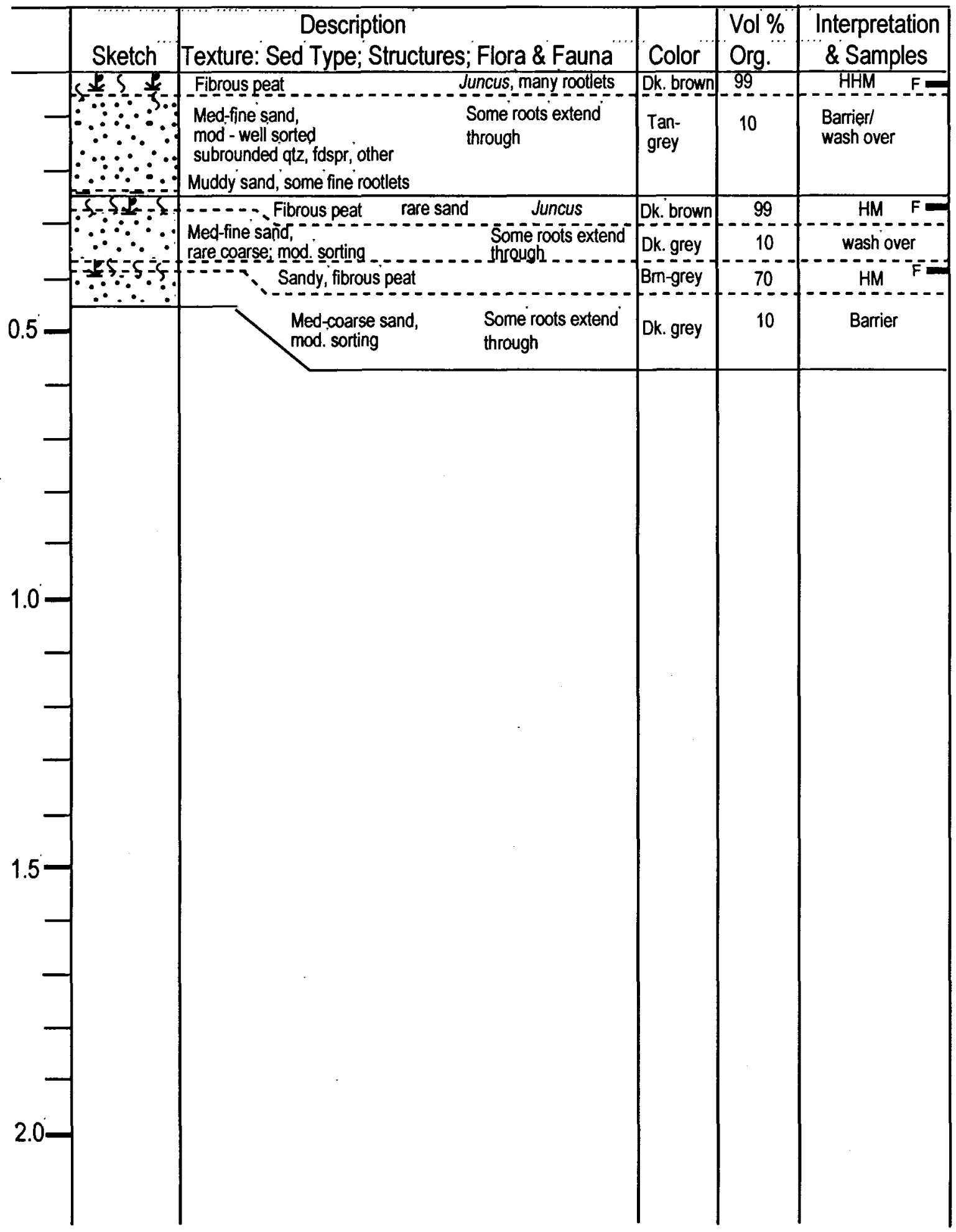


CORE \#: SPI-33

Date: $7-20-00$

Location: St. Paul's Inlet, bog transect

Site Description: Bog

MHW elev: $1.16 \mathrm{~m}$

Length: $0.49 \mathrm{~m}$

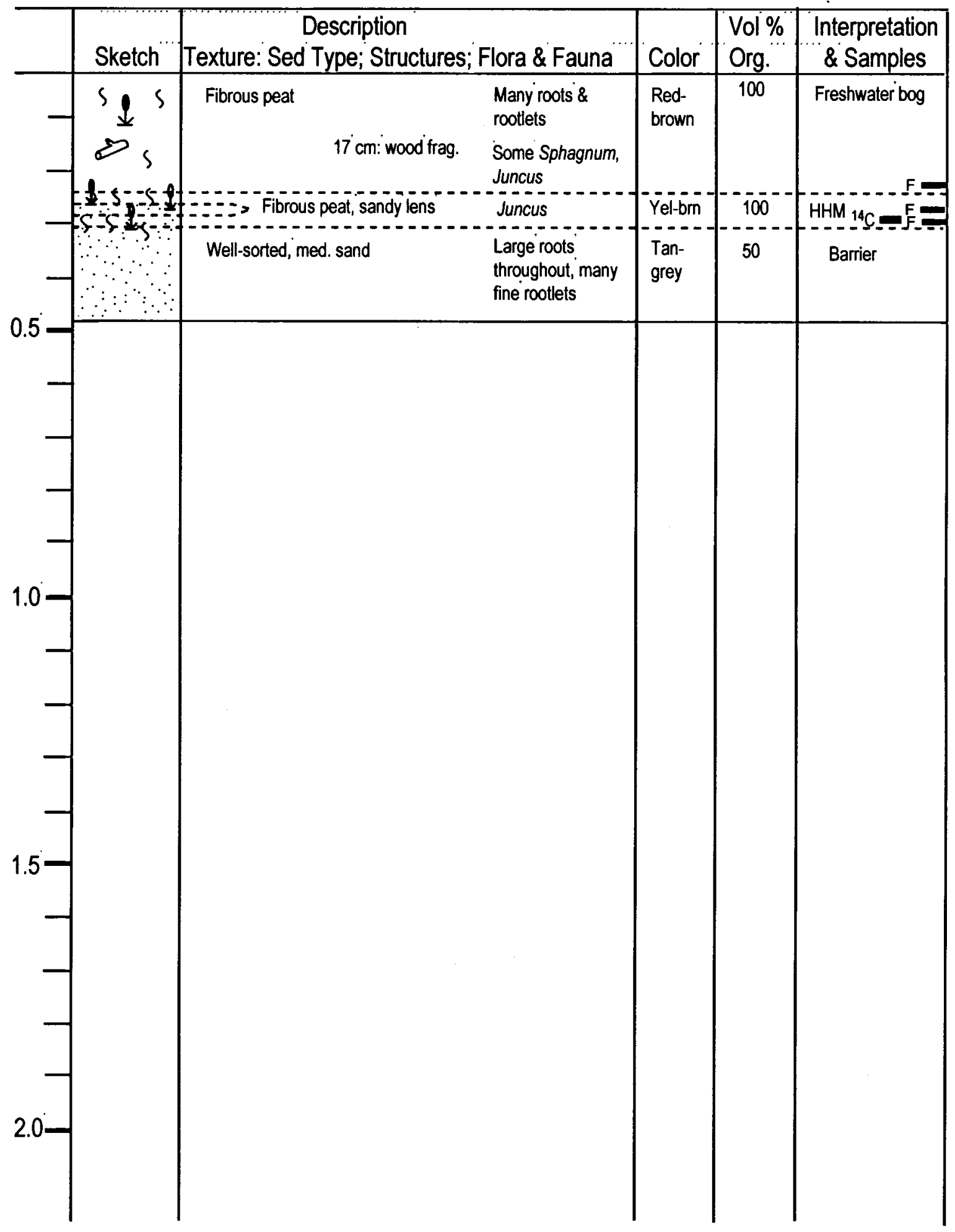


CORE \#: SPI-34

Date: $7-20-00$

Location: St. Paul's Inlet, bog transect

Site Description: Fen/upland

MHW elev: $1.07 \mathrm{~m}$

Length: $0.48 \mathrm{~m}$

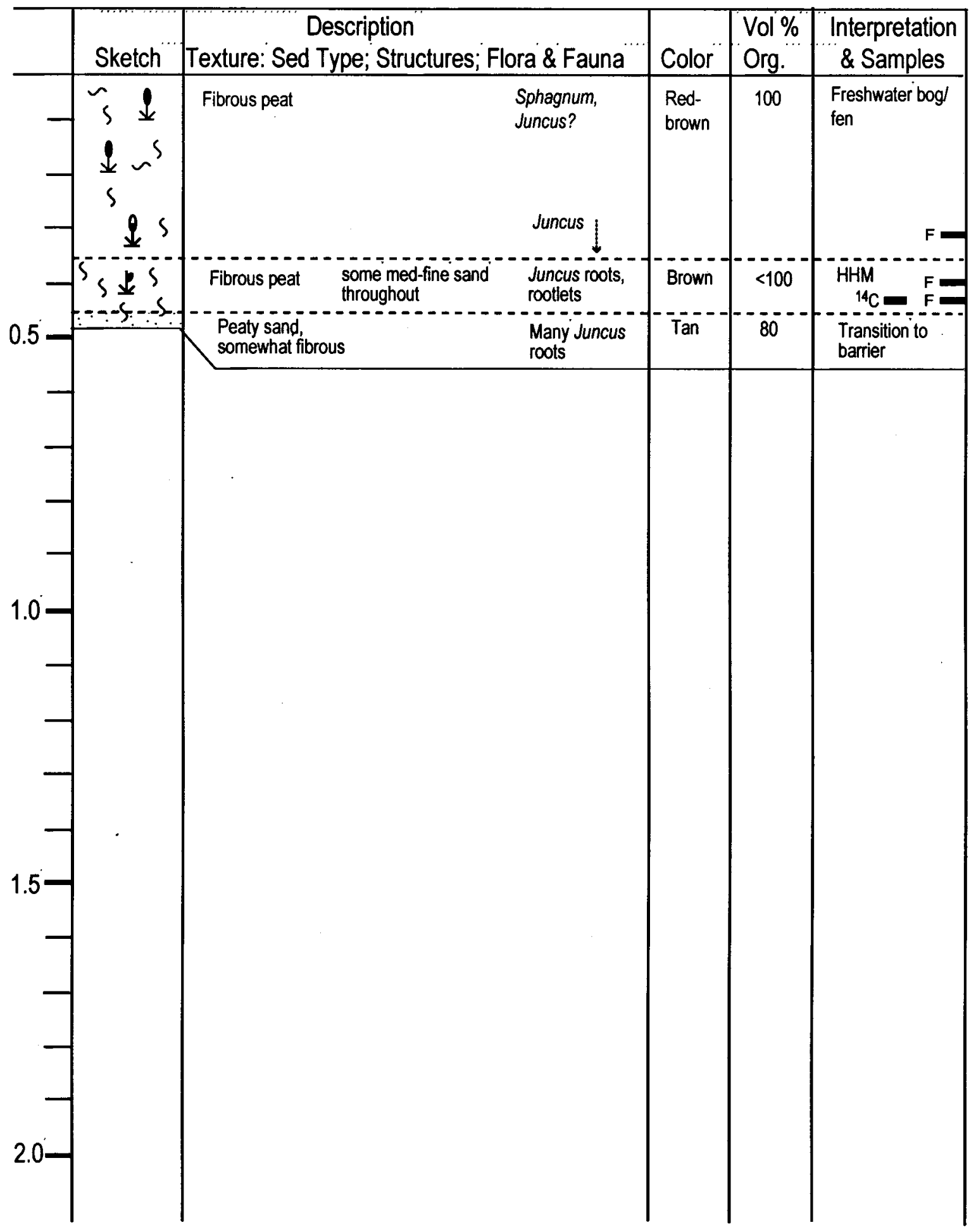


CORE \#: DB-1

Date: $7-19-99$

Location: Deadman's Bay

Site Description: Backbarrier

Elev: $0.23 \mathrm{~m} \quad$ Length: $0.73 \mathrm{~m}$

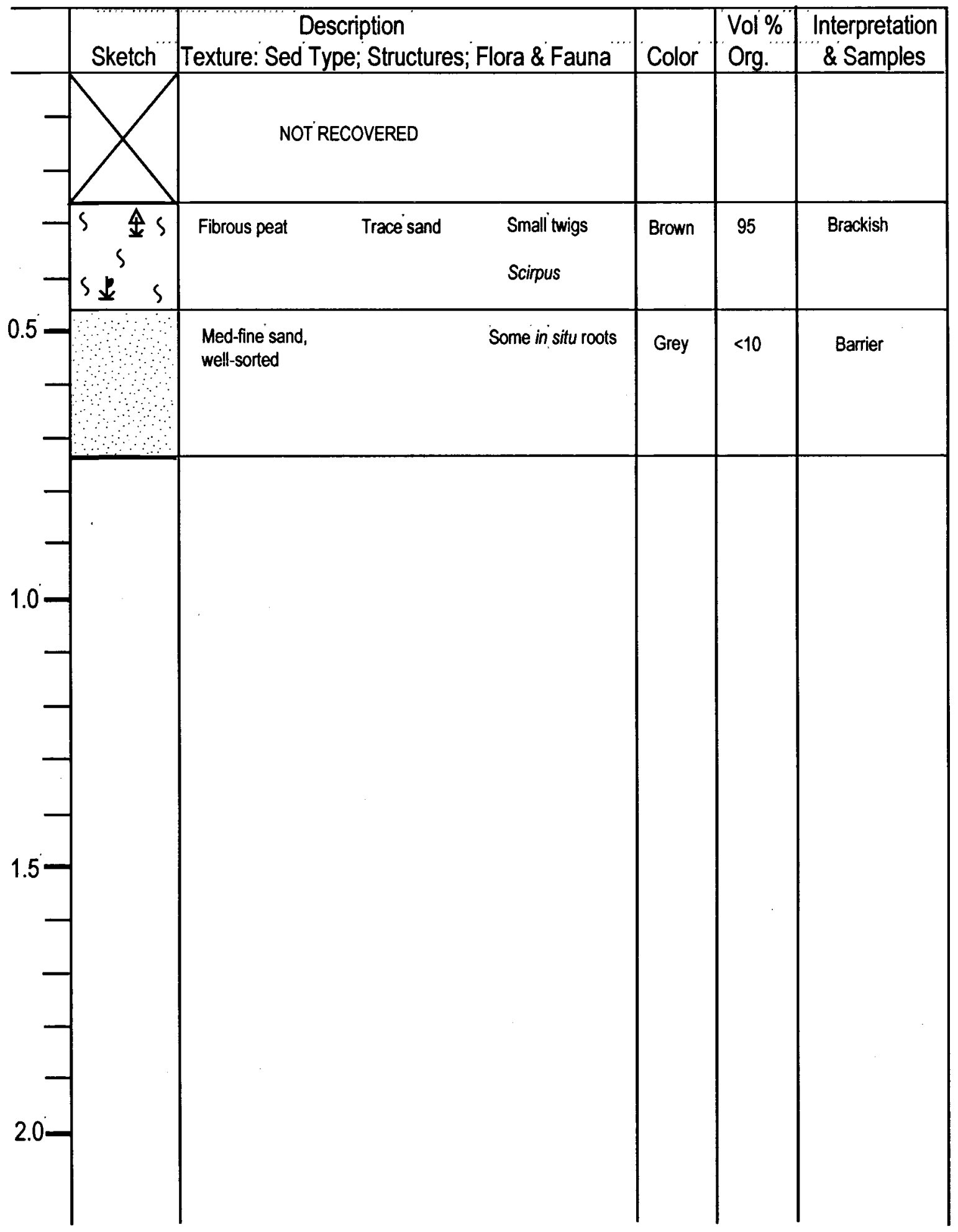


CORE \#: DB-11

Date: $7-19-99$

Location: Deadman's Bay, southern transect

Site Description: Sedge marsh

MHW elev: $0.19 \mathrm{~m}$

Length: $1.0 \mathrm{~m}$

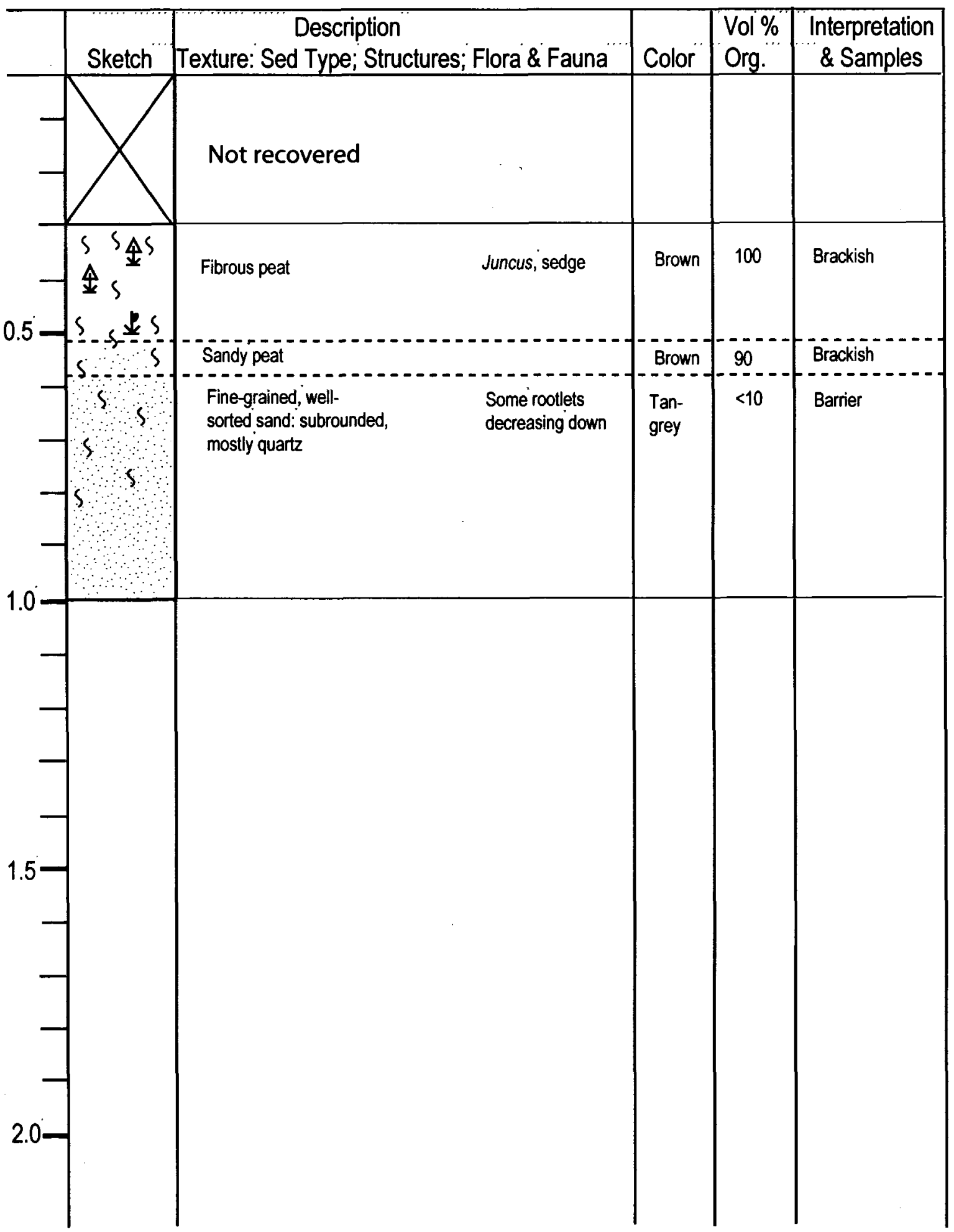


CORE \#: DB-12

Date: $7-19-99$

Location: Deadman's Bay, southern transect

Site Description: Sedge marsh

MHW elev: $0.14 \mathrm{~m}$ Length: $0.79 \mathrm{~m}$

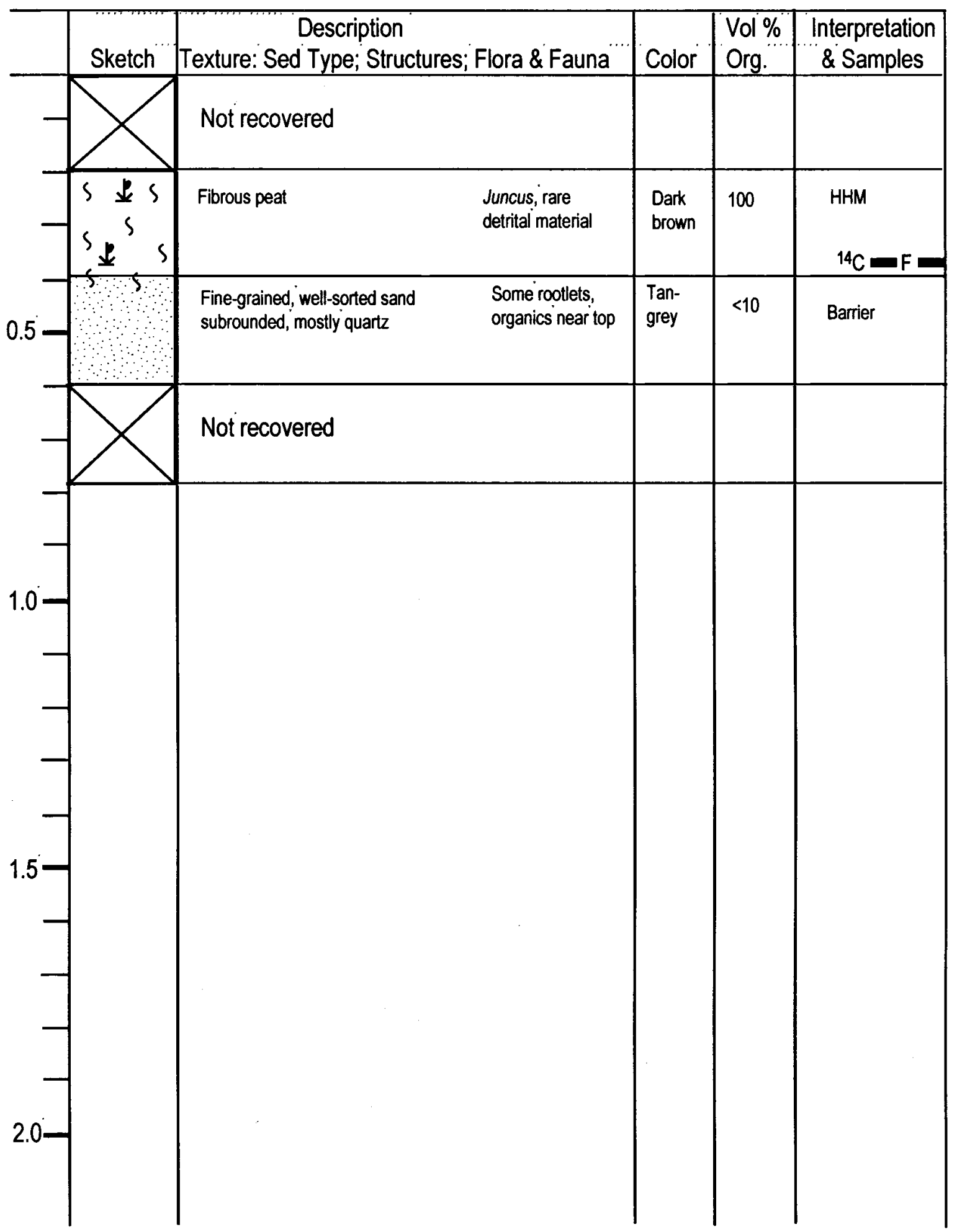


CORE \#: DB-13

Date: $7-19-99$

Location: Deadman's Bay, southern transect

Site Description: sedge marsh

MHW elev: $0.06 \mathrm{~m} \quad$ Length: $1.0 \mathrm{~m}$

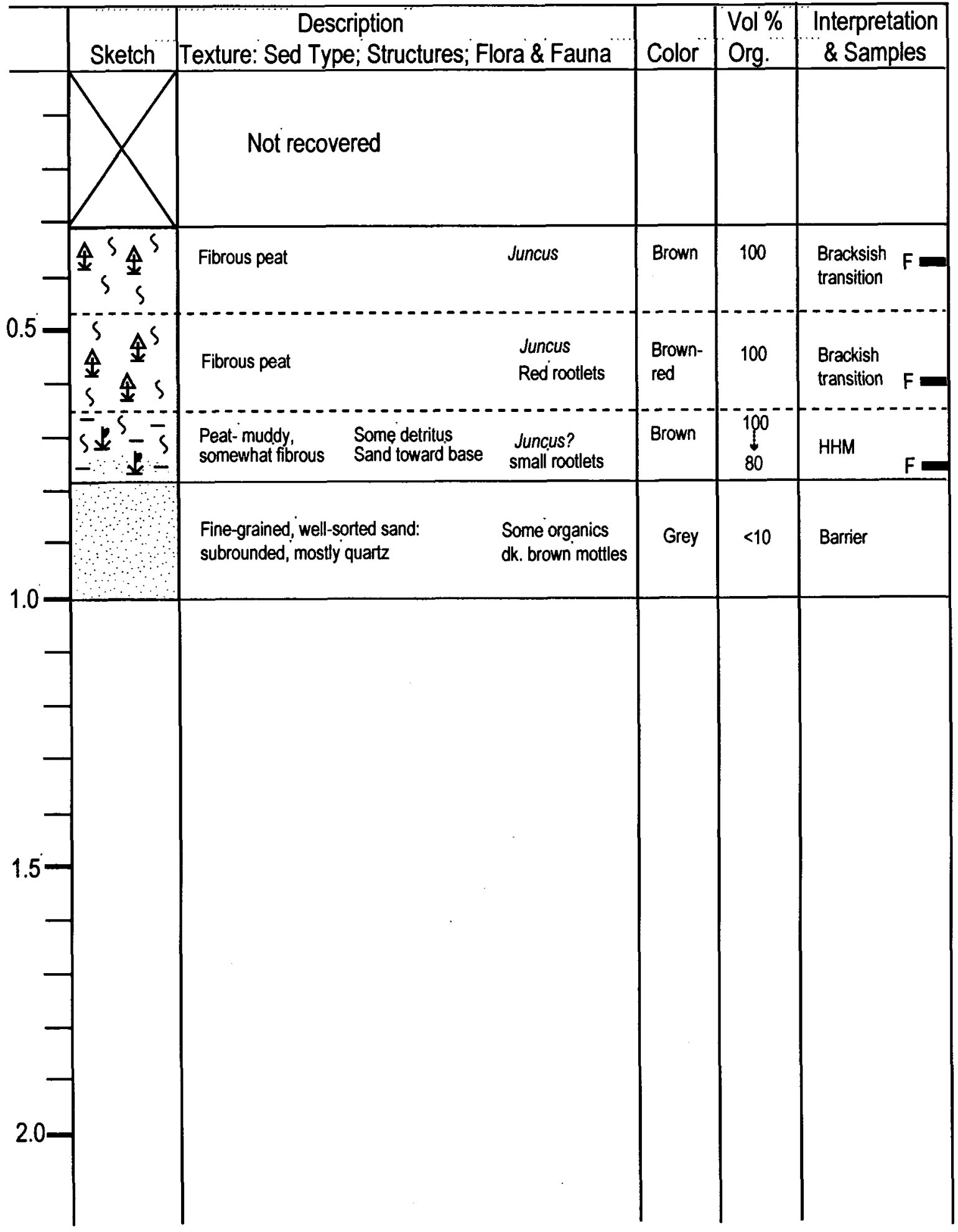


CORE \#: DB-14

Date: $7-20-99$

Location:Deadman's Bay, southern transect

Site Description: Sedge marsh

MHW elev: $0.09 \mathrm{~m}$ Length: $2.0 \mathrm{~m}$

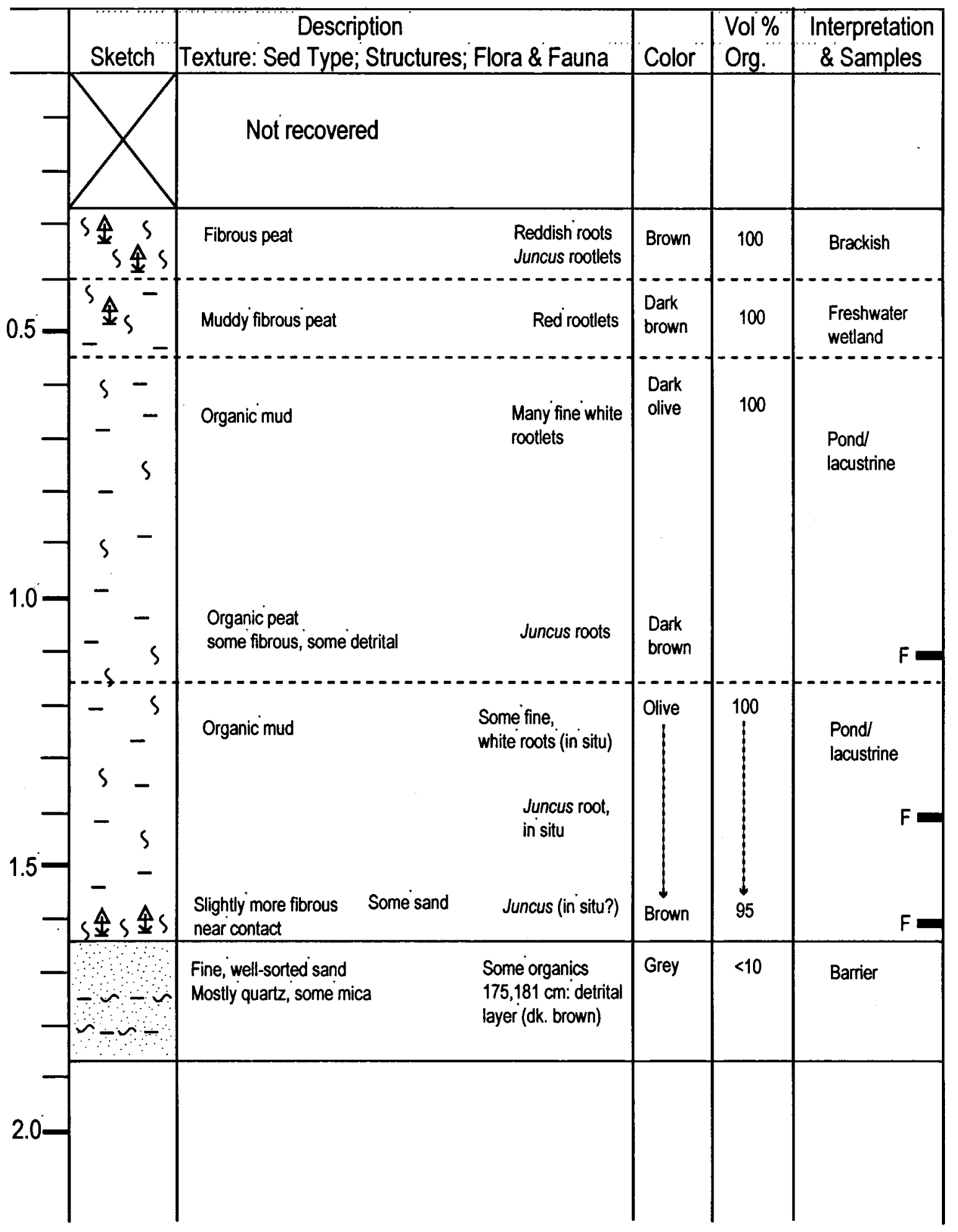


CORE \#: DB-15

Date: $7-20-99$

Location: Deadman's Bay, southern transect

Site Description: Sedge marsh

MHW elev: $0.14 \mathrm{~m}$

Length: $1.78 \mathrm{~m}$

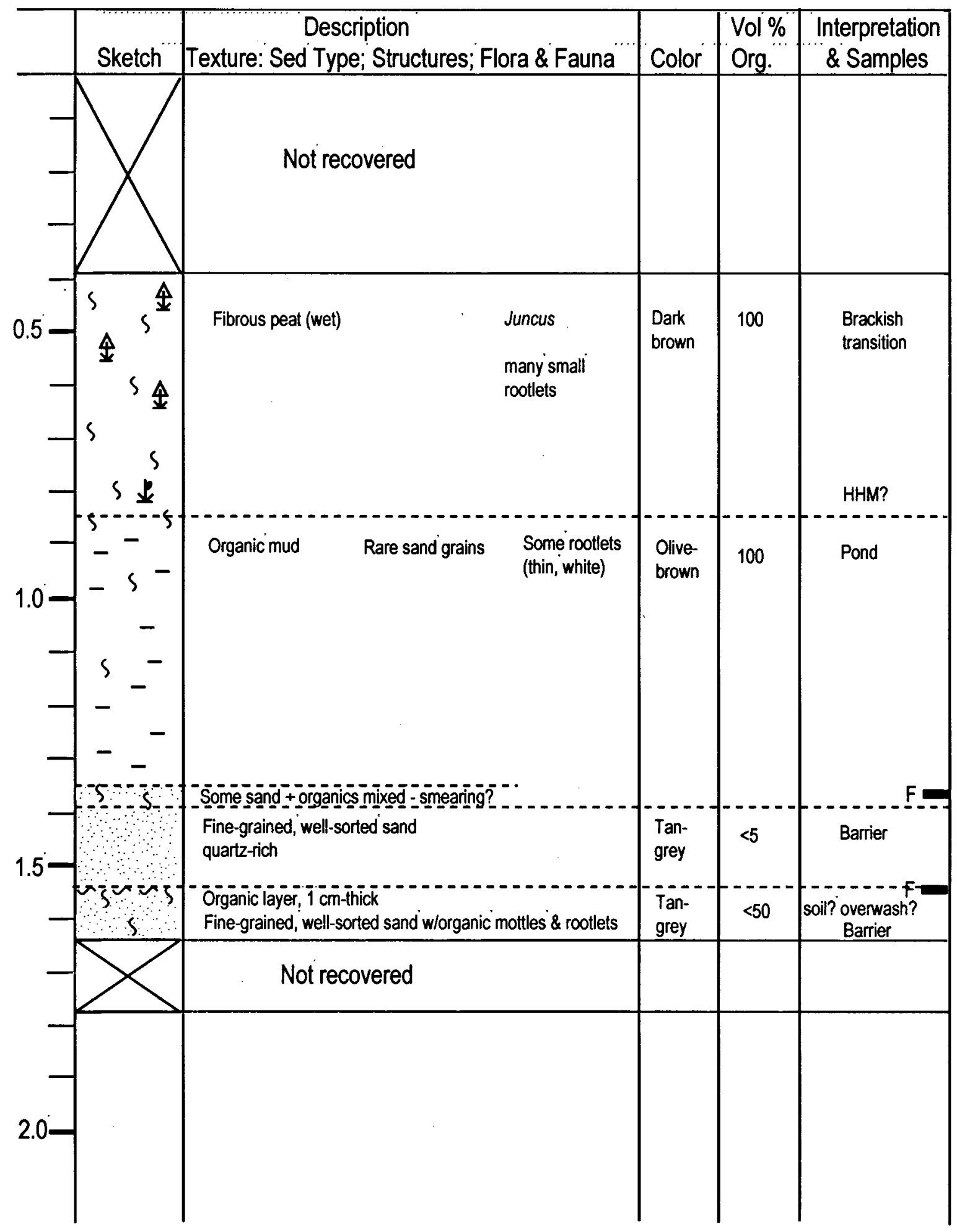


CORE \#: DB-16

Date: $7-20-99$

Location:Deadman's Bay, northern transect

Site Description: Sedge marsh

MHW elev: $0.27 \mathrm{~m}$

Length: $0.63 \mathrm{~m}$

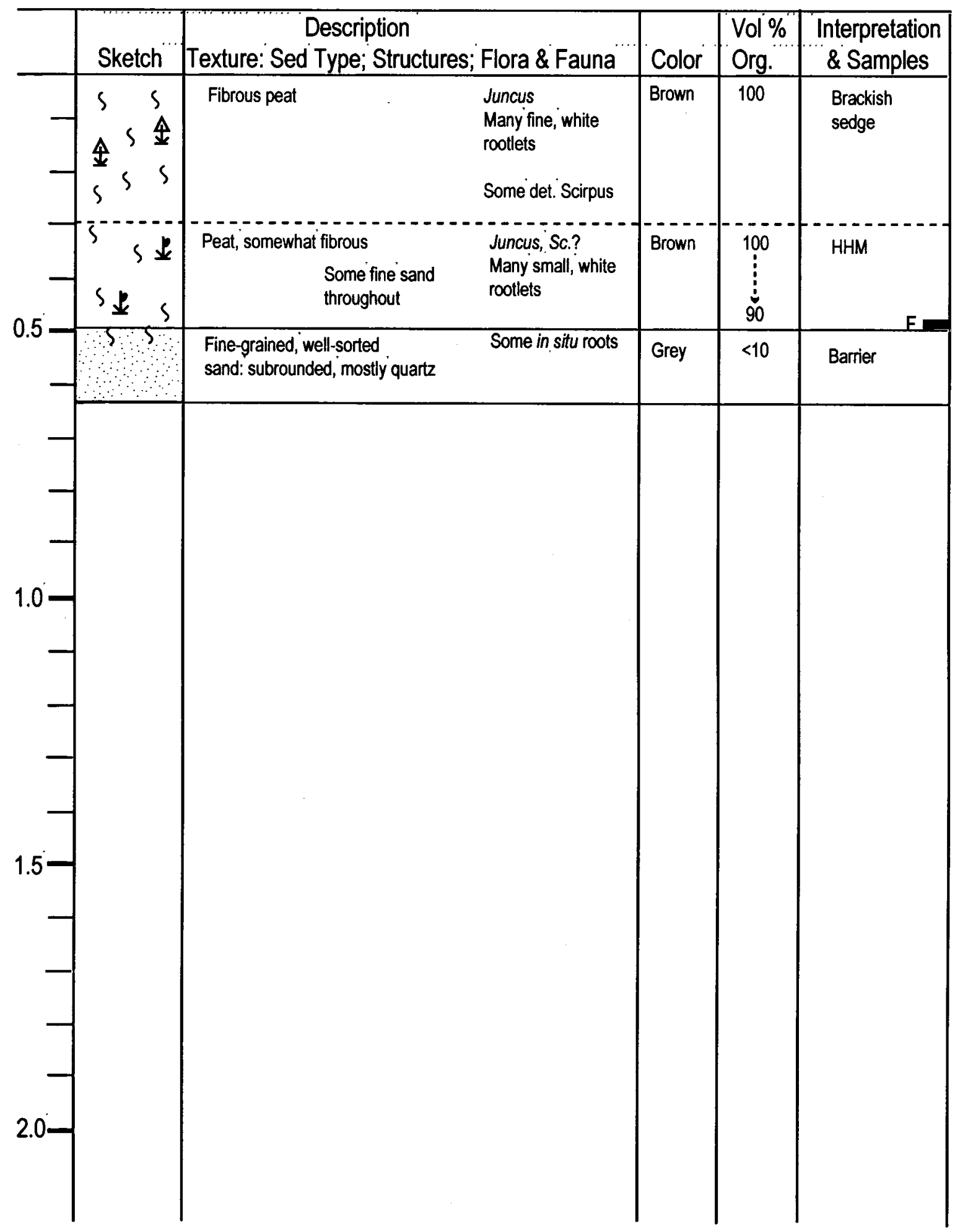


CORE \#: DB-17

Date:" $7-20-99$

Location: Deadman's Bay, northern transect

Site Description: sedge marsh

MHW elev: $0.30 \mathrm{~m}$

Length: $0.80 \mathrm{~m}$

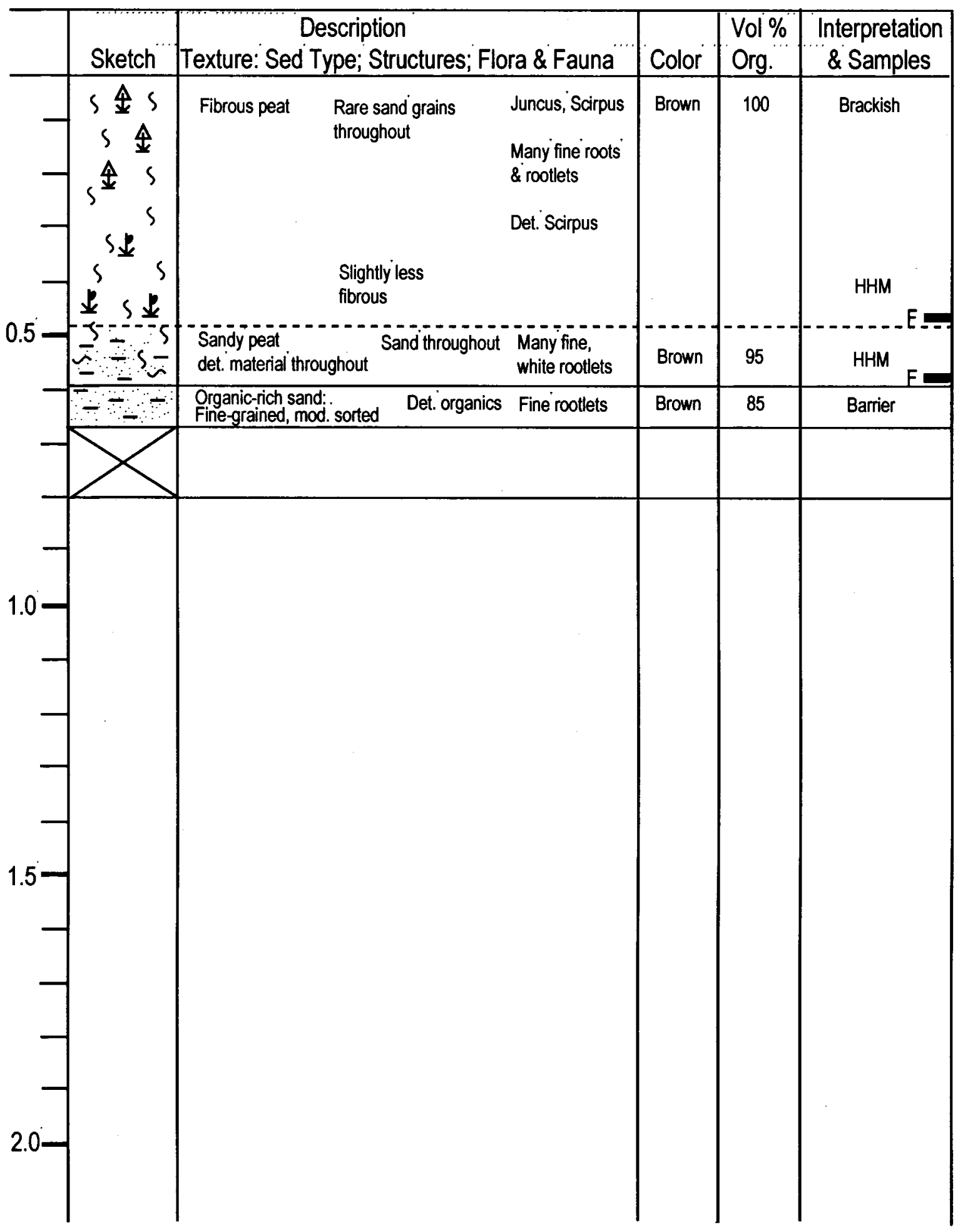


CORE \#: DB-18

Date: $7-20-99$

Location: Deadman's Bay, northern transect

Site Description: sedge marsh

MHW elev: 0.43

Length: $0.66 \mathrm{~m}$

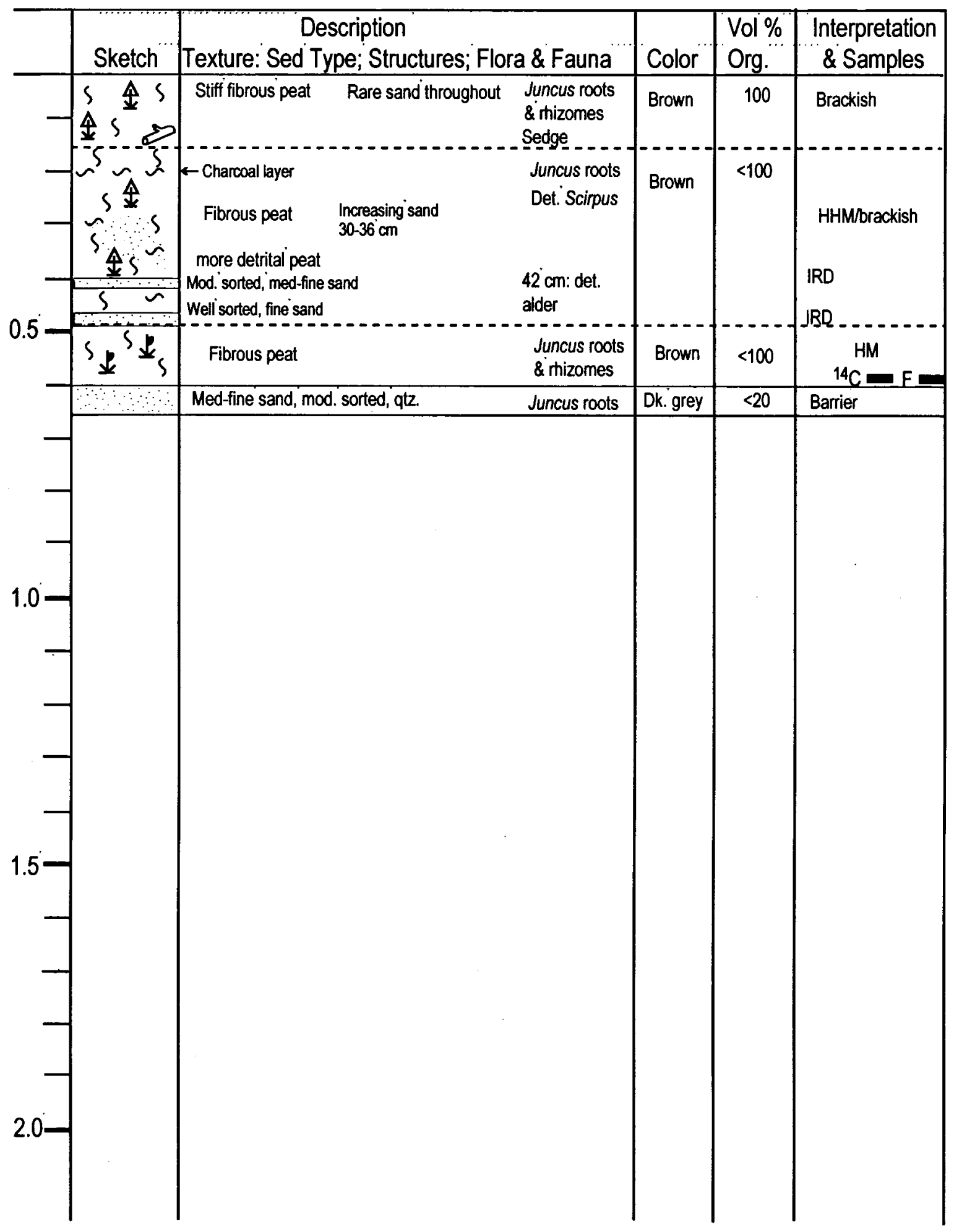


CORE \#: DB-19

Date: $7-20-99$

Location: Deadman's Bay, northern transect

Site Description: sedge marsh

MHW elev: 0.27

Length: $1.0 \mathrm{~m}$

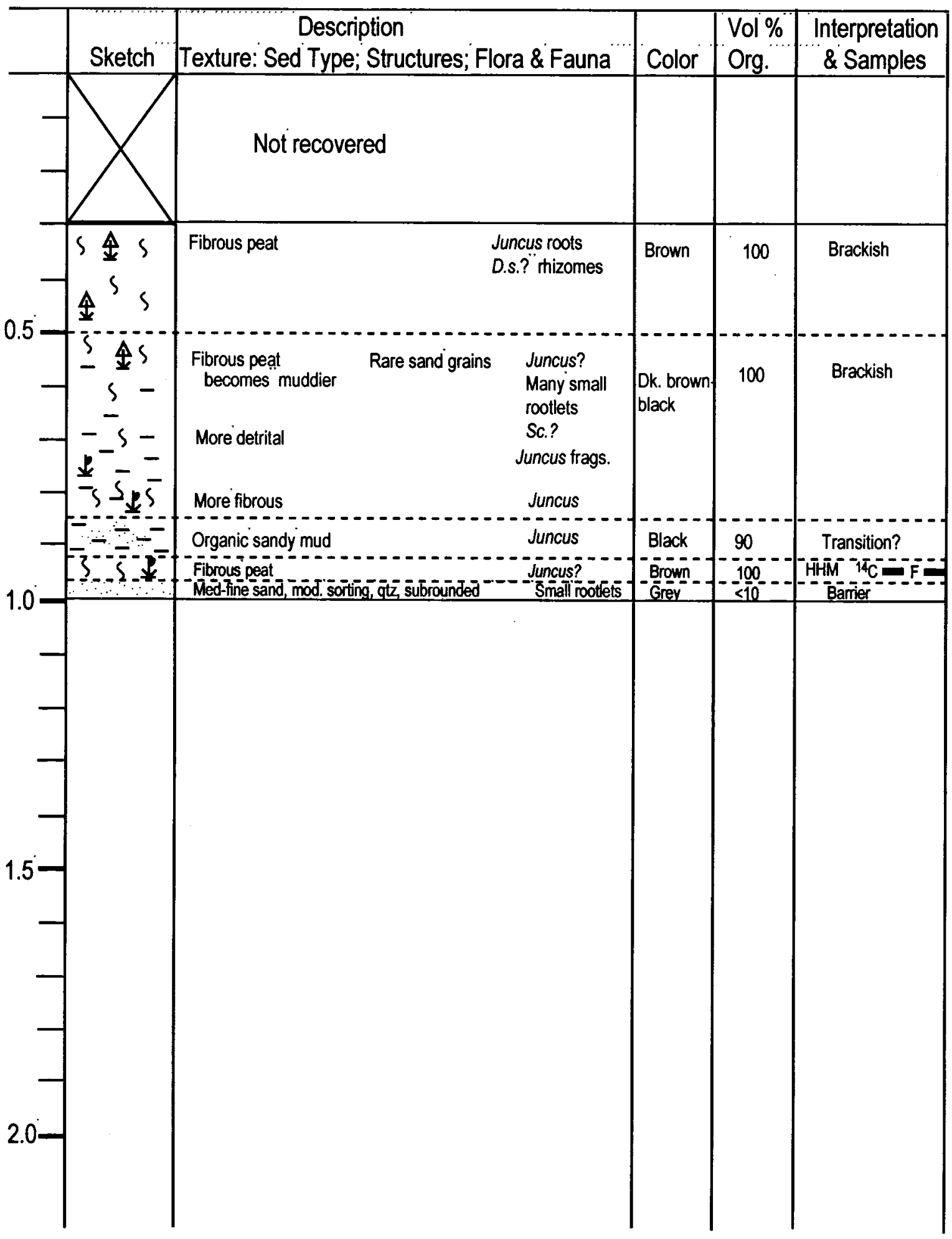


CORE \#: DB-20

Date: $7-20-99$

Location: Deadman's Bay, northern transect

Site Description: sedge marsh

MHW elev: $0.27 \mathrm{~m} \quad$ Length: $1.0 \mathrm{~m}$

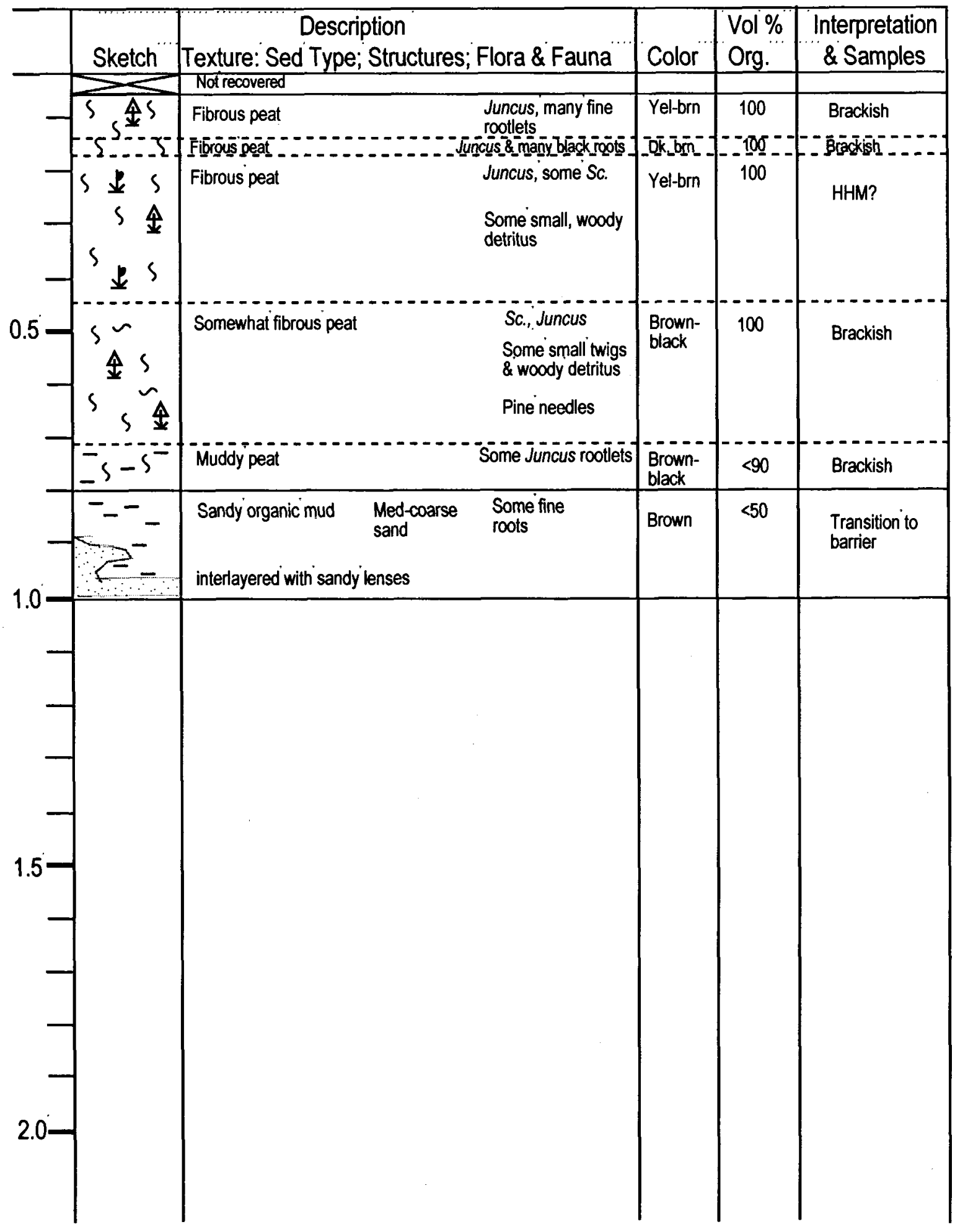


CORE \#: DB-21

Date: $7-20-99$

Location: Deadman's Bay, near site of DB-9, 10

Site Description: sedge marsh

MHW elev: $0.24 \mathrm{~m} \quad$ Length: $0.90 \mathrm{~m}$

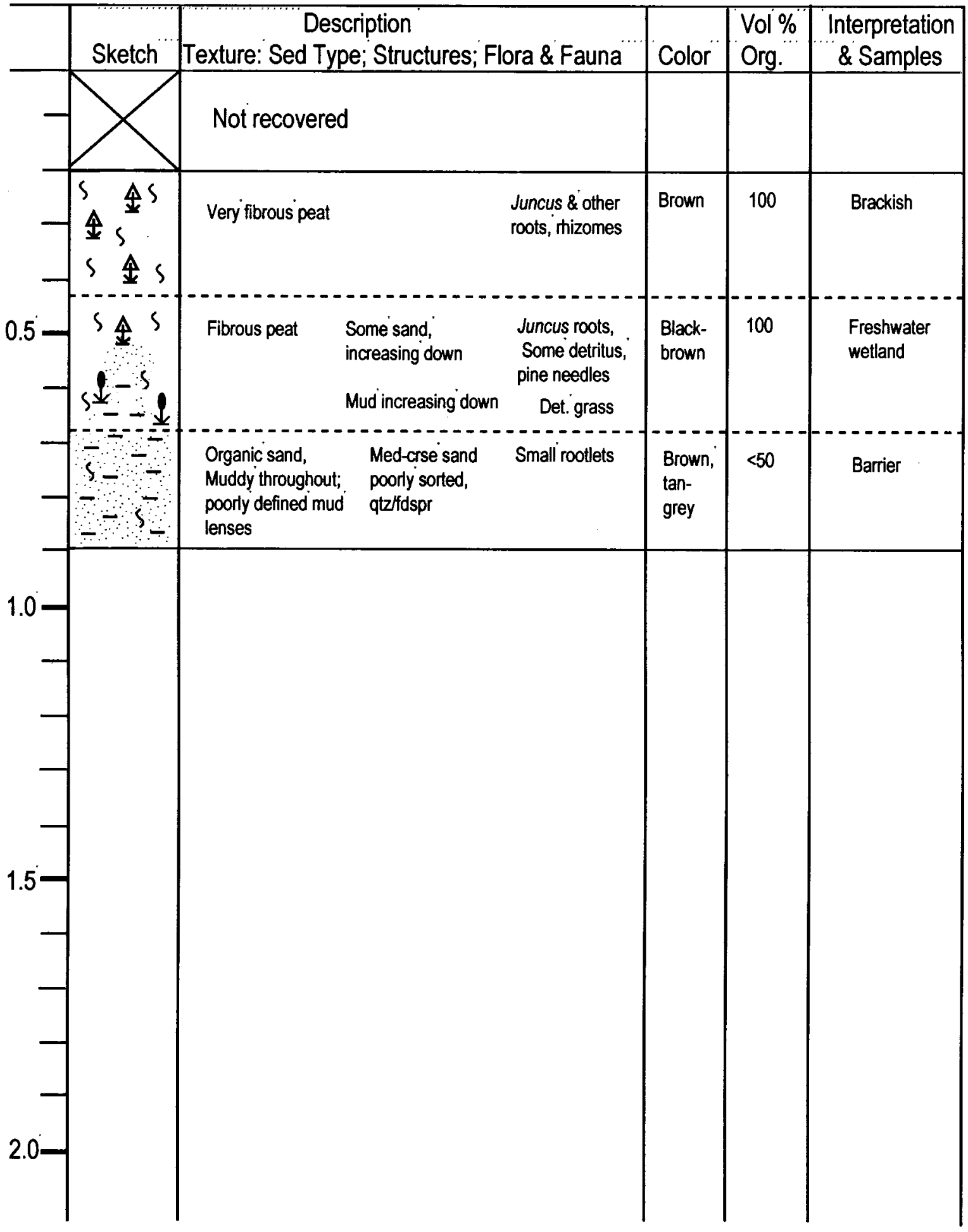


CORE \#: PL-1

Date: $7-28-00$

Location: Southeast Arm, Placentia

Site Description: Upland transition

MHW elev: $0.22 \mathrm{~m}$

Length: $1.56 \mathrm{~m}$

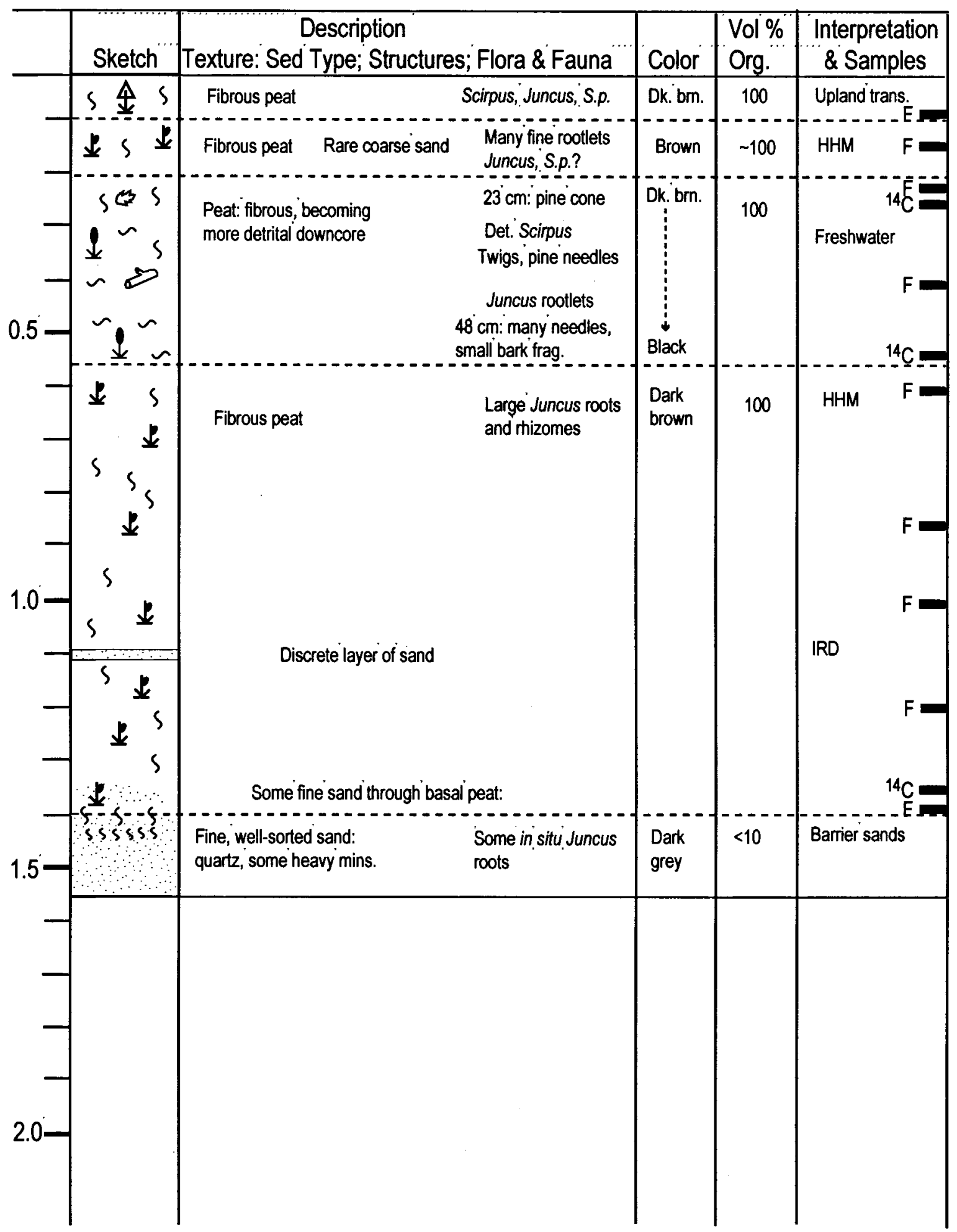


CORE \#: PL-2

Date: 7-28-99

Location: Southeast Arm, Placentia

Site Description: Higher high marsh

Elev: $0.20 \mathrm{~m}$ Length: $1.25 \mathrm{~m}$

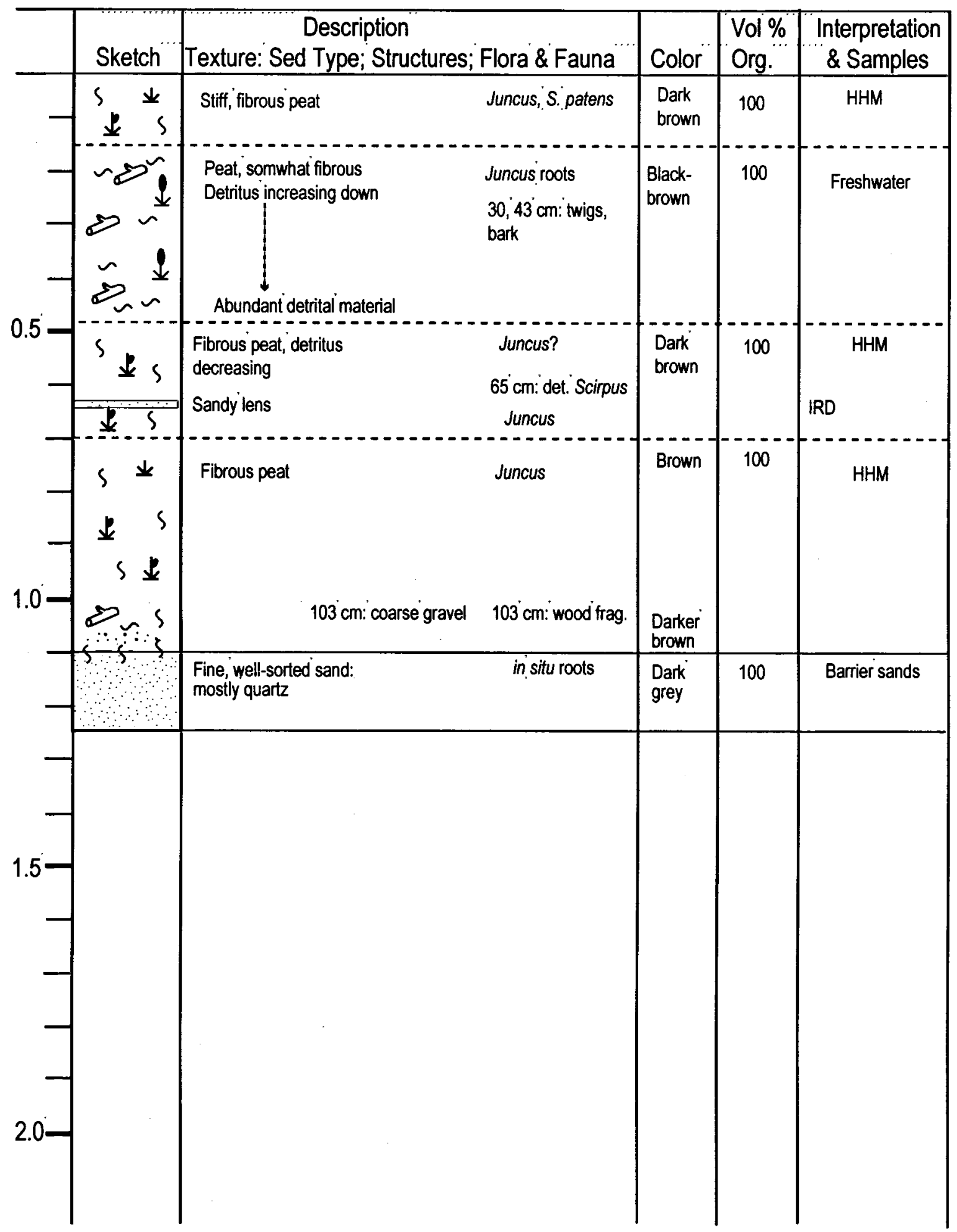


CORE \#: PL-3

Date: $7-28-99$

Location: Southeast Arm, Placentia

Site Description: High marsh

Elev: $0.08 \mathrm{~m} \quad$ Length: $1.38 \mathrm{~m}$

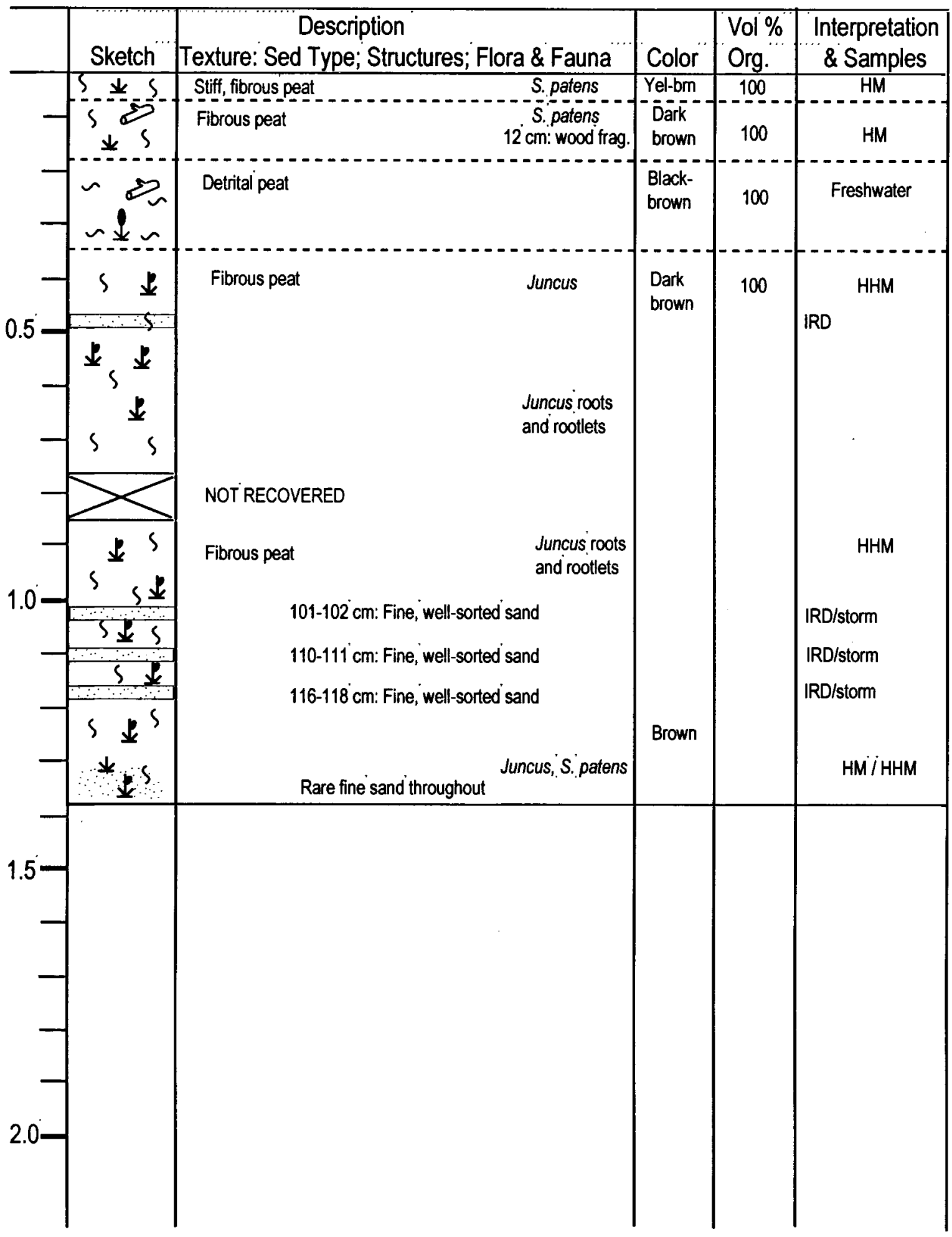


CORE \#: PL-4

Date: 7-28-99

Location: Southeast Arm, Placentia

Site Description: High marsh

Elev: $0.06 \mathrm{~m} \quad$ Length: $1.24 \mathrm{~m}$

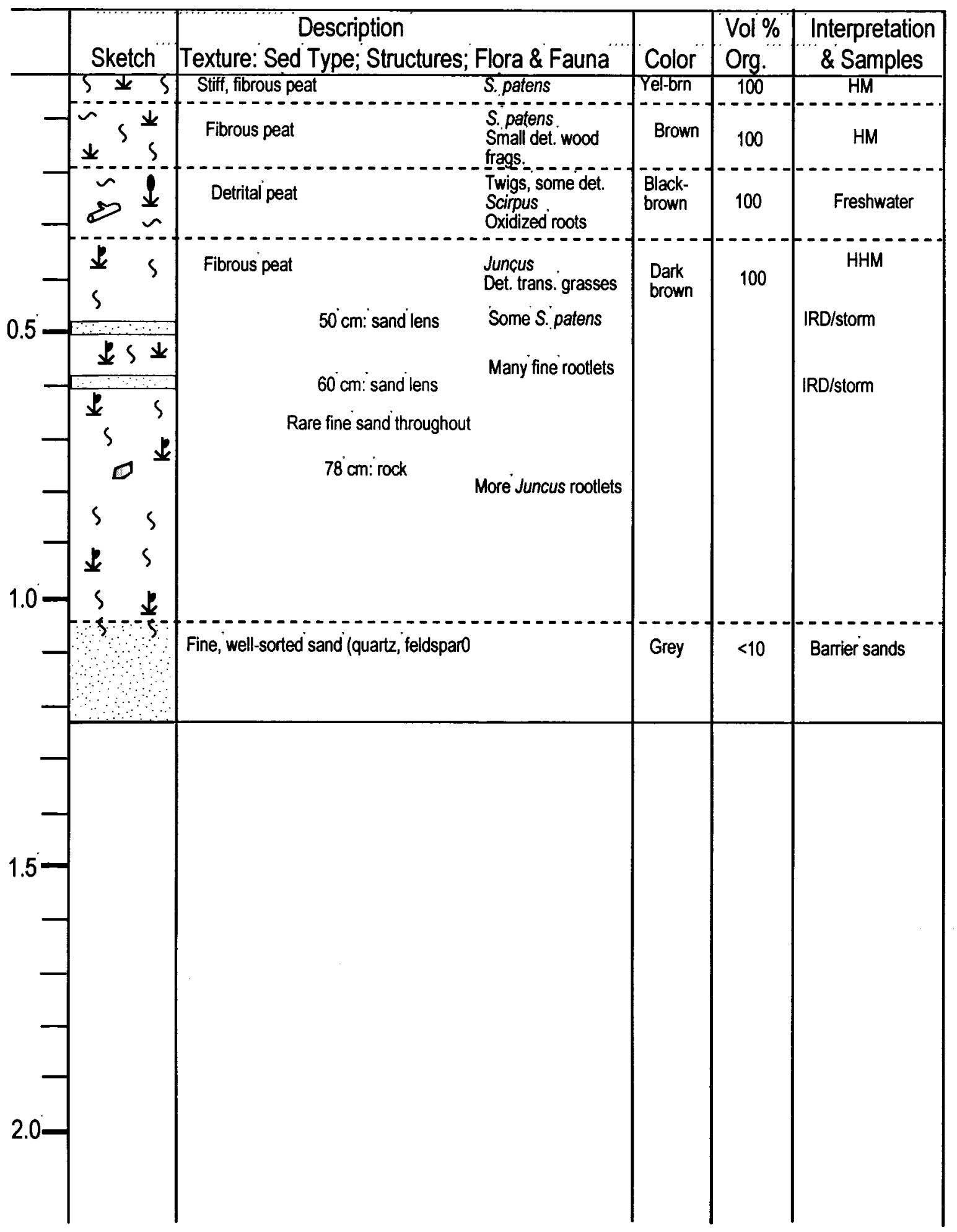


CORE \#: PL-5

Date: $7-28-99$

Location: Southeast Arm, Placentia

Site Description: High marsh

Elev: $-0.02 \mathrm{~m}$

Length: $0.76 \mathrm{~m}$

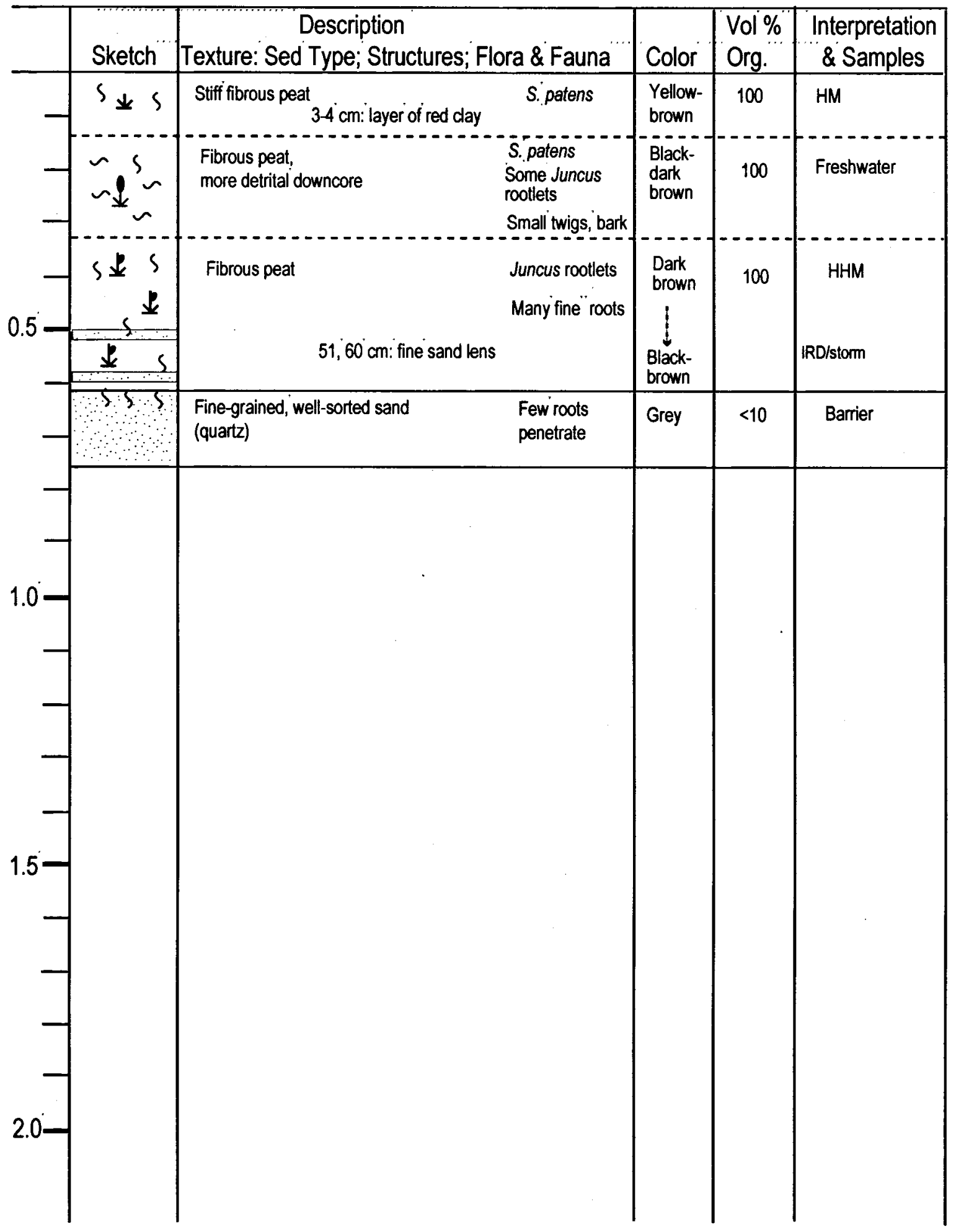




\section{BIOGRAPHY OF THE AUTHOR}

Julia Frances Daly was born January 24, 1972, and graduated from Wellesley High School (Wellesley, MA) in 1990. She attended Carleton College in Northfield, MN, and graduated in 1994 with a B.A. in geology. During her time at Carleton she was fortunate to spend a semester in Tanzania participating in a Wildlife Ecology \& Conservation program. Prior to her senior year, she conducted fieldwork in northern Greece as part of a Keck geoarcheology project. Following graduation, she attended the YBRA field camp in southern Montana and began a thankfully short-lived career in grocery retail. She entered the graduate program at the University of Delaware in 1995, and received a M.S. in geology in 1997. Her Master's thesis focused on the internal structure of coastal landforms as revealed by ground-penetrating radar.

Julia entered the University of Maine in the fall of 1997 , and has enjoyed a variety of fellowship opportunities. In addition to a teaching assistantship, she has been a research assistant for the Margaret Chase Smith Center and the Wells National Estuarine Research Reserve. She had an exciting year as a NSF Graduate K-12 Teaching Fellow teaching science in the Orono school system. During the spring of 2002, she was a sabbatical replacement at University of Maine - Presque Isle. She and her partner, Doug Reusch, have been hired to share the Forrest P. Dexter III Chair in Geology at the University of Maine - Farmington beginning in the fall of 2002. She is a candidate for the Doctor of Philosophy degree in Geological Sciences from the Univeristy of Maine in August, 2002. 